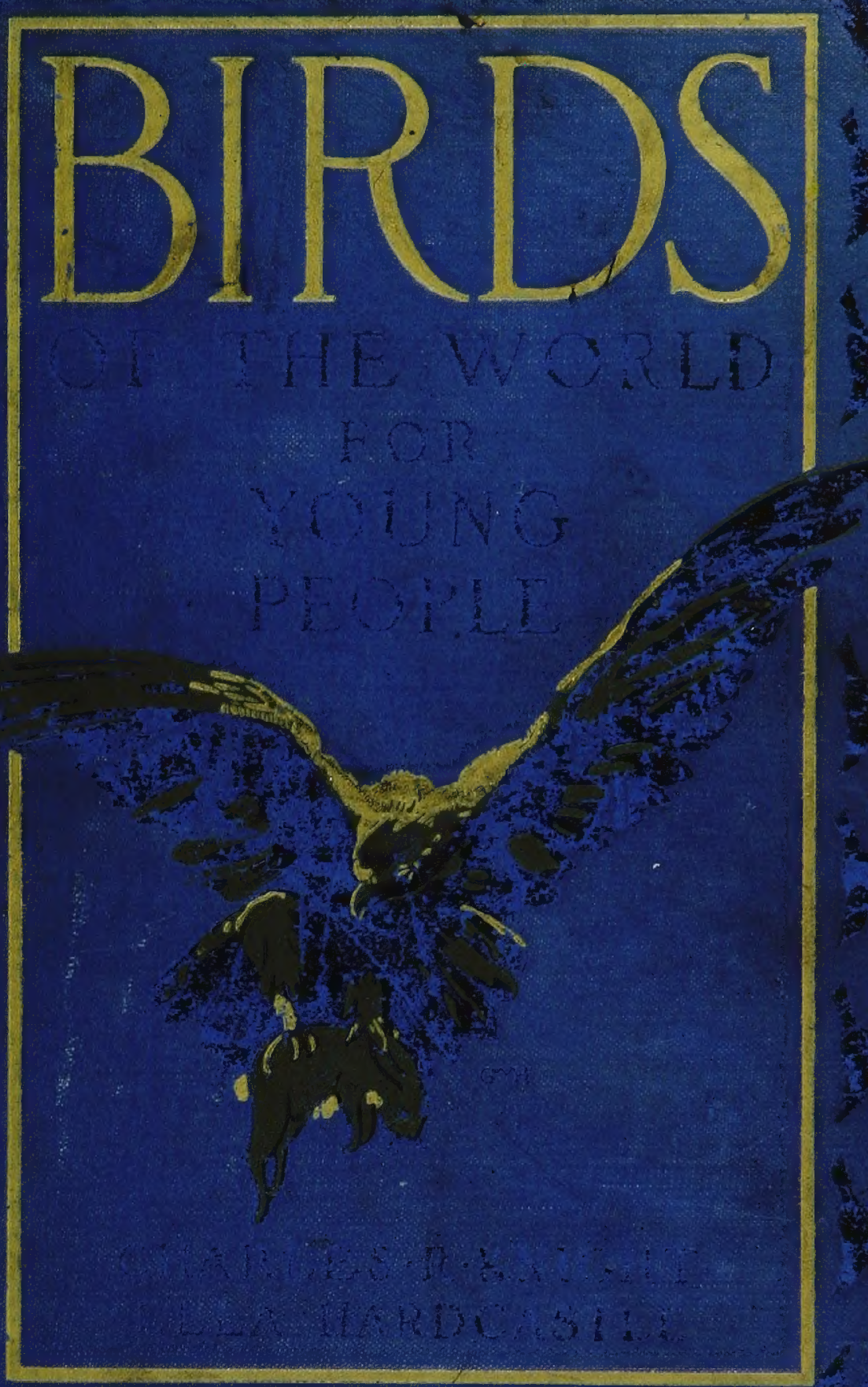


boltimore orese Bnower of hush : sparingur 
Detertso Alany 


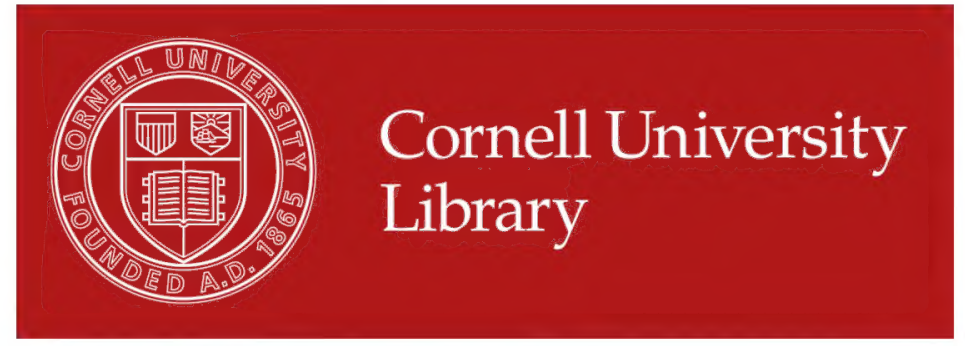

The original of this book is in the Cornell University Library.

There are no known copyright restrictions in the United States on the use of the text. 



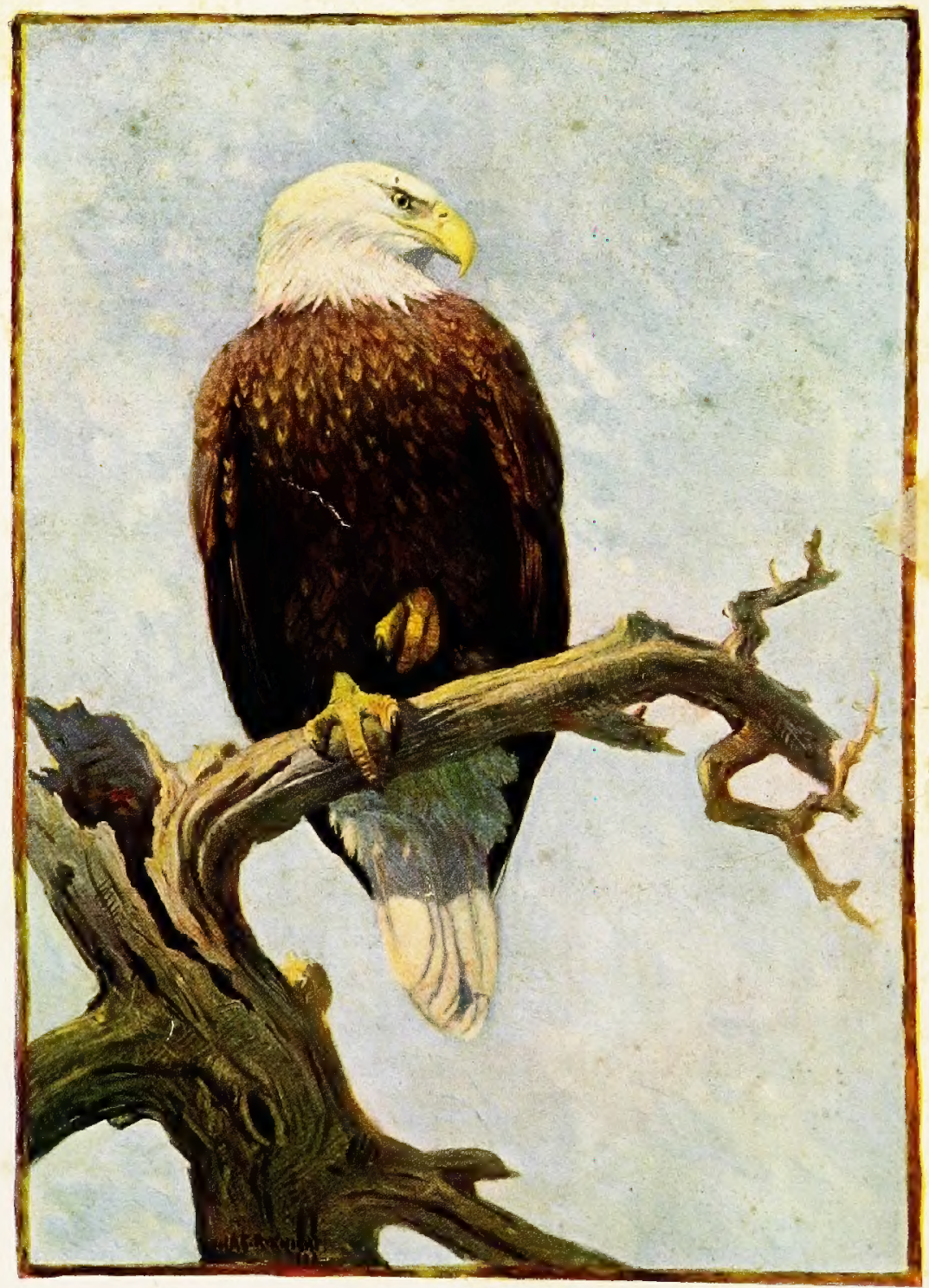

American, or Bald, Eagle, (Haliaetus Lencocephalus). 


\title{
BIRDS OF THE WORLD
}

FOR

\section{YOUNG PEOPLE}

\author{
BY \\ CHARLES R. KNIGHT \\ AND \\ ELLA HARDCASTLE
}

WITH FORTY-ONE COLOUR PLATES AND NUMEROUS BLACK-AND-WHITE ILLUSTRATIONS

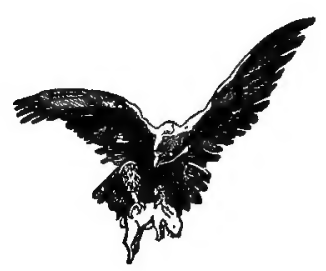

NEW YORK

FREDERICK A. STOKES COMPANY PUBLISHERS 


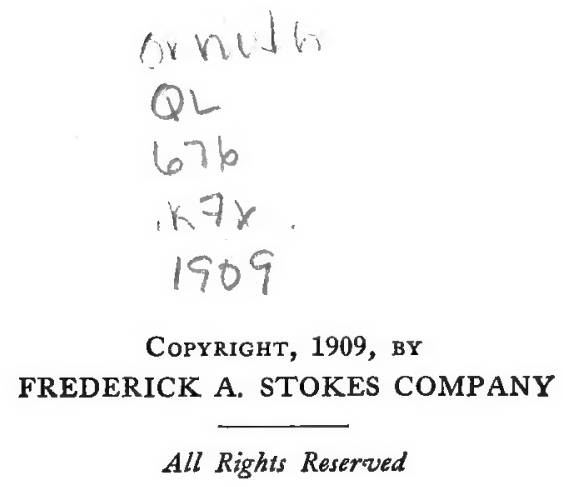




\section{PREFACE}

THe object in the present volume has been to give a brief description of such birds of the world as are usually to be seen in zoölogical collections and in museums, together with some of the most significant and striking facts in their life-histories. To include even a very short account of each of the fourteen thousand species known to exist, was clearly impracticable within the limits of a book of this size. It has been thought desirable, therefore, to give special attention to the birds of America, to corresponding species and allied forms found in Great Britain and on the Continent of Europe, and to certain of the more remarkable and interesting birds of other countries.

This work is based upon one by W. P. Pycraft, well known among ornithologists as a systematist and bird anatomist, and now in charge of the Department of Birds in the British Museum. Use has been made of a large part of his admirable Introduction, dealing with the evolution and structure of the bird. Portions of it that were considered too technical to be readily. understood by young readers were simplified as much as possible, other portions were omitted as being of comparatively little value, and a few additions were 
made. The general arrangement has been adhered to throughout.

The interest in birds is widespread and constantly growing, and it is hoped that the use of this volume as a reference-book will lead young readers to further study of this most fascinating subject. 


\section{CONTENTS}

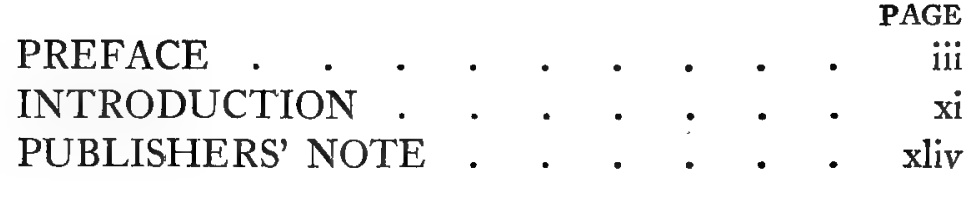

CHAPTER I

OSTRICH-LIKE BIRDS .

(Orders-Casuarii, Struthiones, Apteryges, Crypturi.)

\section{CHAPTER II}

Carinate, or Keel-breasted Birds . . . Io .

\section{CHAPTER III}

Diving-Birds, Petrels, and Penguins

(Orders-Pygopodes, Tubinares, and ImI4 pennes.)

\section{CHAPTER IV}

Totipalmate Birds: Herons, Storks, and Flamingoes

(Orders-Steganopodes, Ardeæ, Ciconæ, and Phøenicopteri.)

\section{CHAPTER V}

Ducks, Geese, and Swans

(Order-Anseres.) 


\section{CHAPTER VI}

Birds of Prey: Secretary-bird, Eagles, Buzzards, Hawks, Kites, Vultures, and FALCONS

(Order-Accipitres.)

PAGE

\section{CHAPTER VII}

FOWL-LIKE BIRDS

(Order-Galliformes.)

CHAPTER VIII

Cranes, Rails, ANd Bustards
(Order-Gruiformes.)
CHAPTER IX

Plovers, Gulls, ANd Auks ; • • • • (Order-Charadriiformes.)

CHAPTER' $\mathrm{X}$

Pigeons .

(Order-Columbæ.)

\section{CHAPTER XI}

Parrots and Cuckoos
(Orders-Psittaci and Cuculi.)
CHAPTER XII

Rollers, Motmots, Kingfishers, Bee-eaters, HoOPOES, AND HORNBILlS . • • • . $\mathrm{I}_{42}$ (Order-Coraciæ.) 


\section{CHAPTER XIII}

PAGE

Nightjars, Swifts, And Humming-Birds . 148 (Orders-Caprimulgi, Cypseli.)

\section{CHAPTER XIV}

OwLS

(Or $\dot{\text { der-Striges.) }}$

\section{CHAPTER XV}

Trogons, Toucans, And Woodpeckers . . ${ }^{6} 64$ (Orders-Trogones and Pici.)

\section{CHAPTER XVI}

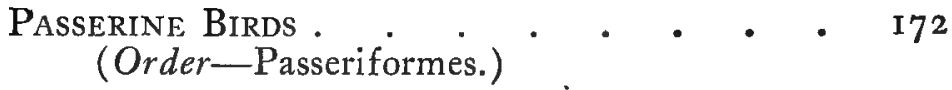

INDEX 



\section{LIST OF COLOUR PLATES}

Bald Eagle .

Plate i

Plate 2

Plate -3

Plate 4

Plate 5

Plate 6

Plate 7

Plate 8

Plate 9

Plate io

Plate i I

Plate I 2

Plate 13

Plate I4

Plate 15

Plate i6

Plate I7

Plate i 8

Plate i 9

Plate 20

Plate 2 I

Plate 22

Plate 23
Frontispiece Facing page 74 Facing page 70 Facing page 64 Facing page 60 Facing page 160 Facing page I68 Facing page $\mathrm{I} 34$ Facing page ${ }_{1} 38$ Facing page 144 Facing page 182 Facing page I96 Facing page 200 Facing page 206 Facing page $2 \mathrm{I} 2$ Facing page I 86 Facing page 220 Facing page 226 Facing page 2 I 6 Facing page 176 Facing page 230 Facing page I 52 Facing page 126 Facing page 130 
Plate 24

Plate 25

Facing page 88

Plate 26

Plate 27

Plate 28

Plate 29

Facing page 86

Facing page 84

Facing page 80

Facing page 4

Plate 30

Facing paige 96

Plate 3

Plate 32

Plate 33

Facing page 104

Facing page 108

Facing page I I 2

Plate 34 . . . . . Facing page 36

Plate 35 . . . . . . Facing page 5a

Plate 36 . . . . . . Facing page 46

Plate 37 - • • • . . Facing page 26

Plate 38 - . . . . . Facing page II6

Plate 39 - . . . . . Facing page I6

Plate 40 . . . . . Facing page 20

\section{FULL-PAGE HALF-TONE PLATES}

Plate 4I - . . . . . Facing page 92 Plate 42 - • • • • . Facing page 98 


\section{INTRODUCTION}

ПHE study of birds, or Ornithology, began long before the dawn of civilisation. At first, to primitive man the bird represented only a kind of food, and the study of birds' habits and peculiarities must have had its beginning after pursuit had made birds wary and only to be caught by some knowledge of their character and haunts. With better knowledge of birds, as of other animals, it was found that some species might be kept and bred in captivity, thus giving a regular and certain kind of food. With the keeping of fowls, of dogs, of cattle, sheep, and horses, began the pastoral or shepherd stage of civilisation, which came earliest in man's upward progress toward a settled life. All the complex communities of to-day may be traced back to such simple beginnings, and the domestication of animals was by no means a small factor in man's progress. The freedom of birds, their mastery of the regions of the air, their mysterious goings and comings-some, or all, of these gave them a peculiar fascination and caused them from the earliest times to be regarded with religious awe as being closely allied to the gods, or with superstitious fear and reverence as partaking of the strange powers of the air. No doubt they seemed to be in some sense dwellers in lands of the 
gods. Whatever the reason, birds have been in every land connected with religious observances or superstitious rites, and even chosen as symbols of power, authority, or wisdom. No doubt their expressive cries contributed much to this result. The folk-lore in every nation gives evidence of this feeling. It is found among the Hindus, the Egyptians, the Greeks, the Romans, and the European nations alike.

But the scientific study of birds cannot be said to have begun until very recent times. The foundations of ornithology were laid by two Englishmen, Francis Willughby (1635-1672) and John Ray (1628-1705), to whom we owe the first attempts to classify birds upon right principles. Their good work was based upon practical observation combined with the ability to rightly weigh and analyse. Though to-day other ideas prevail in regard to the relationship and classifying of species, yet Willughby and Ray are still regarded as pioneers in ornithology. In this chapter our purpose is to give a brief summary of the state of our knowledge of birds at this time, rather than to trace even in outline the progress of the science during the last two or three centuries.

Let us begin with the question: What is a bird? Briefly, a bird is distinguished from all other living creatures by its covering of feathers. Not thus alone, however, are birds distinguished, since they differ almost as markedly in the matter of their skeletons. But it is not enough that we should be able to quote the "hall-mark," so to speak, by which our favorites are to be recognised. At least it is not enough for those of us who are not content with mere facts. 
Thus, then, we ask, How have the birds come by these distinguishing characters? The answer to this question has been supplied partly by the anatomist and partly by those who have spent their lives in reading the riddles of the rocks. Let us take the anatomist's evidence first. According to him, the peculiarities which distinguish the bird have been derived from reptiles, and this is nowhere more evident than in the skull. As in the reptile, it joins the neck by a single, rounded boss of bone; while in the mammals (the great class to which we ourselves belong, the class distinguished by the body covering of hair, and the fact that the young are suckled) the skull joins the neck by two such bosses. In the form of the backbone and of the hip-girdle, and in the structure of the legs, birds also agree with the reptiles. To state in full the evidence on which these conclusions are founded

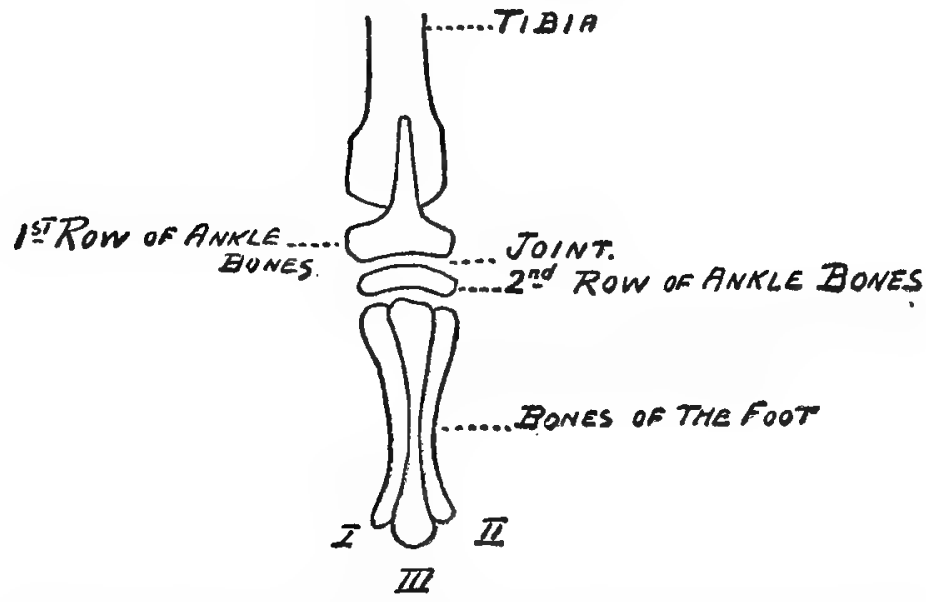

Fig. 1.-Bones of the foot ANd ANKLE of a young Fowl, showING THE SEPARATE ELEMENTS THEREOF. 
might be wearisome to those who are not particularly interested, but we may indicate the nature of the argument by a comparison of the hind limb of the bird and reptile. This limb, in both, is peculiar in that the ankle-joint is formed in such a way that when the foot is bent the joint turns on a hinge formed between two rows of ankle-bones, while in mammals the joint is formed by the hinging of the shank of the leg upon the uppermost row of ankle-bones. But the bird's leg is peculiar in that these two rows of anklebones have undergone great modifications, and can be seen in their originally separate condition only by examining the chick some time before hatching, though traces yet remain in a young fowl of, say, three months old (see Fig. 1). It is owing to the fact that these peculiarities are not generally known, that most books on birds are inaccurate when they describe the "legs and toes" of a bird, the legs being the long "cannonbones," which are clad in scales and often brightly coloured.

A reference to the accompanying diagram should make this clear. Here we have the leg of a fowl. The first joint is formed by the hinging of the femur, or thigh-bone, with the tibia, thus forming the "kneejoint." At the end of the tibia is the joint with the ankle-bone; but in the birds, as we have said, the two rows which these small bones make up disappear before adult life is reached. One row (shown in Fig. 1), composed in the half-grown bird of a malletlike piece, the handle of which runs up the front of the tibia or shank, becomes welded to the "shank"; while the other ("2nd Row," Fig. 1), composed of 
several small pieces originally, but now forming a thin plate, becomes welded on to the top of the bones of the foot. It it these last which are always, but wrongly, described as the "leg-bones." Really, they answer to the bones of our own feet which lie between the ankle and the toes. Finally, we have the toes, about which there can be no mistake.

The great lengthening of the foot-bones has been brought about by the evolution of the bird from a climbing to a walking animal. Originally they were five in number, but are now, like the toes, reduced to four. Of these four, three are now welded together-Nos. I, II, III-to form a single "cannonbone," answering to that of the horse; but in the young bird their originally separate condition can still be traced (see Fig. 1). The first

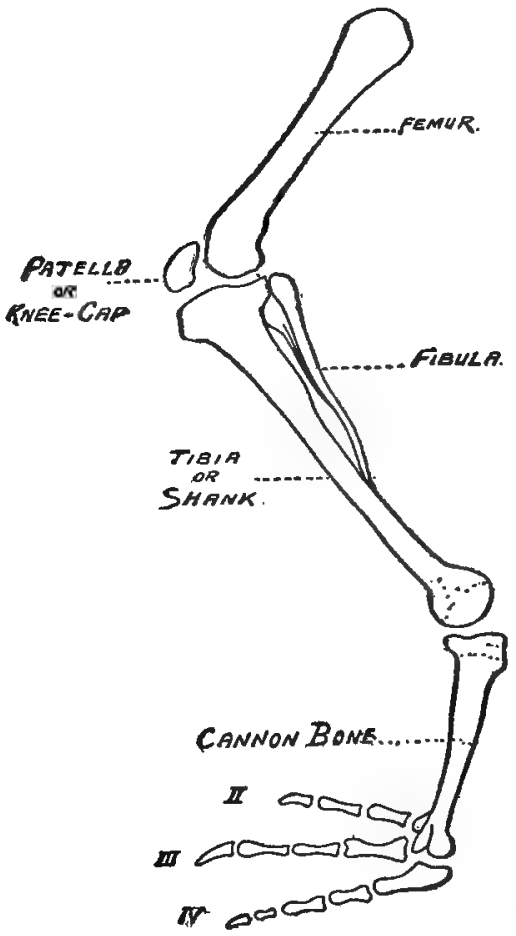
Fig, 2.-Diagram of the leg of AN ADULT BIRD, 'SHOWING THE CONDITION OF THE LIMB AFTER THE SEPARATE ELEMENTS HAVE BECOME WELDED.

of these foot-bones answering to the hind-toe is now reduced to a mere "button" of bone slung by ligaments on to the cannon-bone." The leg of the old 
giant reptiles known as the Dinosaurs corresponds marvellously well with that of a modern bird, only in the reptiles the foot-bones had not become welded to form a cannon-bone. So much, then, for the evidence from the skeleton, for the present. The arrangement of the blood-vessels, the structure of the eye, ear, organ of smell, and brains, are all on the reptile plan, and so also are the organs of reproduction. Similarly, the microscopic structure of the growing feather in the embryo, or unhatched chick, shows that it is really an extremely elaborate reptile scale, and is formed on a plan quite different from the hairs of mammals.

But, it may be urged, it is all very well, and it may be quite true, to say that because the reptiles and the

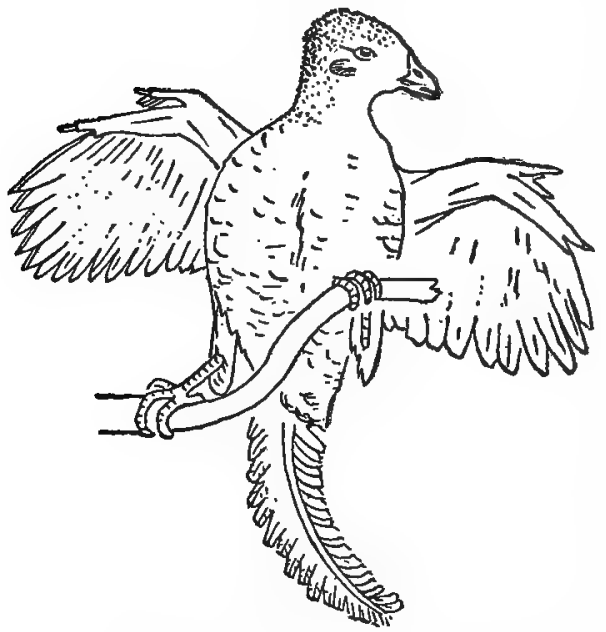

Fig. 3.-The FiRSt KNOWN BIRD.

birds have so much in common, therefore they must be related. But why should we assume this? One of two courses is open to u s. Either we must believe that birds were, as used to be held, specially created, or that they have inherited the characters which they hold in common with reptiles from a common ancestor which had the characteristics which distinguish rep- 
tiles to-day. And in support of the reasonableness of this latter view we may appeal to the evidence which the rocks have preserved for us in the shape of the fossil remains of ancestral birds. In these we have still further and more striking proof of the descent of birds from reptiles, and the gradual change from the reptile to the bird type.

The earliest fossil bird yet discovered is that known as Archæopteryx, and this differed from all other birds in one or two very important particulars. In each case these differences serve to bridge the gap between the reptiles and the birds, though it must be admitted many other links are necessary to make the chain complete. In the first place, instead of the horny sheaths which cover the beak of living birds, we find the jaws were provided with teeth, set in sockets like those of the crocodile; in the second, the tail was of great length and made up of a long row of bones, as in the tail of reptiles. Each bone supported a pair of feathers, as may be seen in our illustration, so that in this respect it was neither like that of the reptile nor of the typical bird. In the latter, the tail is apparently fashioned after a very different manner.

When we come to examine the arrangement of the tail-feathers in a bird, we find that they are set fanwise about a plate of bone, the last of a series of the eight separate tail-bones which form the termination of the backbone. But it must be remembered that what is commonly called the "tail" is really only the outward sign of this appendage, for feathers, alone, 
no more make the tail of a bird than hair makes the tail of a dog. Now if we examine this bony plate in the embryo, say, of a duck, we shall find that it is really made up of six or seven separate vertebræ, which have become, as it were, telescoped. Each of these represents one of the feather-bearing vertebræ in the tail of Archæopteryx; but by the process of telescoping - this process of shrinking-they have brought the bases of the feathers they supported close together in the fan-wise shape we have just described.

Here, then, we have a lesson in the evolution of birds-a transformation that will go far to help realise how similar changes could bring about the evolution of the ancient reptile into the modern bird. Some day, without doubt, a yet older form of bird will be discovered, which will show even more reptilian characters.

Another strong proof of the identity of the two forms in origin is found in the study of the development of the egg into the chick. It is well known that the gradual changes which may be studied here repeat to some extent the history of the species from the earliest to the latest form, and the fact that the early embryonic development of birds agrees with the belief that they are descended from the same ancestral form as the reptiles, is supported by the conclusion arrived at by embryologists.

Birds, then, in the possession of feathers, are unique in the scheme of nature; so that by this character alone they are distinguished from all other backboned animals. There can be no doubt that they owe their descent to some reptilian ancestor. Let us now pass 
on to consider one or two other peculiarities of birdspeculiarities which have gone on developing and perfecting since the time when birds branched off from the reptile stock.

Surely the most important of these is to be found in the fore-limb. This we know as the "wing." When stripped of its feathers, we could trace the wingstructure of the bird in the fore-leg of any other animal. Yet it cannot be used as an absolutely distinctive character, since in some of the Ostrich tribe, for example, it has become degenerate and so reduced in size as to be hardly recognised; while, if we take fossil forms into consideration, we shall find that it becomes still more dwarfed, until, as in the Moas, it is lost altogether.

The principal features in which the wing differs from the fore-limb of other animals are found in the bones of the "wrist" and "hand." In the wrist only two separate bones appear, though in the embryo the rudiments of several can be made out; these disappear, however, before hatching. The bones of the hand and fingers are reduced to three in number-the thumb and first and second fingers. The first portion of these finger-bones, which answer to the bones that extend between the wrist and the bases of the fingers and make up the palms of our hands, are firmly welded together, the base of the thumb being hardly traceable. The second and third are welded together at each end, enclosing a space, while the finger-joints are represented, in the second finger by two or sometimes three bones, and the third by one bone only.

The remarkable wrist and hand have reached this 
unique stage of development as a response to the peculiar need of the bird's flight, the hand being drawn out into a long rod, across which the bases of the quill-feathers are securely lashed by ligaments. The wing, no less than the rest of the skeleton, furnishes convincing evidence to show that the bird, as we see it to-day, has acquired this form by a slow transformation. In many birds, as in the Duck, the Water-hen, or any of the Hawks, there will be found on the thumb and the tip of the second finger a small claw-the vestige of a claw that once was useful. In some other birds, as in the common Fowl, similar claws will be found in the embryo-in the chick before it leaves the shell-though quite commonly the thumb-claws persist throughout life. Examine the wing of the next Fowl you come across, and likely enough you will find it.

Now, if we go back to Archæopteryx, we shall find that the wing possessed a large claw on each of its three fingers; and also, in this ancient bird we find that the second row of wrist-bones-those at the base of the fingers - though welded together to form a halfmoon-shaped bone, yet remained distinct from the fingers. They, in fact, retained throughout life the condition which is met with to-day only in very young birds. When a yet more ancient bird than Archæopteryx is discovered, it is safe to predict that a still more complex series of wrist-bones will be found. We expect, indeed, to find all the links from the reptile to the bird of the present time.

In one particular the bird and the reptile are very different, inasmuch as while reptiles are cold-blooded, 
birds are hot-blooded creatures; indeed, their blood is much warmer than that of mammals, the temperature ranging from $100^{\circ}$ to $112^{\circ}$. The highest figure is attained by the smaller perching birds, such as Finches; Hawks do not maintain a temperature above $109^{\circ}$, and Gulls only a little above $104^{\circ}$.

This rise in the temperature of the blood is due to several causes too technical to be here discussed. But chief among them is the fact that the heart of the bird, like that of the mammal, is a four-chambered heart, whereby a more perfect oxidation of the blood is possible than is the case with reptiles, in which the heart has but three chambers. And for this reason: When passed through a four-chambered heart, the impure blood brought back from the body to the right side of the heart is driven through the lungs to be thoroughly purified by the air drawn in during breathing; it is then received by the left side of the heart, thence to be sent over the body without any mingling: of the two streams. In the reptile this mingling takes place, and consequently a smaller relative quantity of the heat-giving oxygen is brought into the system. But, strangely enough, the blood of reptiles and birds agree in this, that the little red bodies, or "corpuscles," whose duty it is to absorb the air from the lungs and the carbonic acid from the tissues of the body, have each a central "kernel," or nucleus, whereas the blood-corpuscles of mammals have no such nucleus.

To expand further this matter of the temperature of the blood a somewhat intimate knowledge of physiology and chemistry would be required in the reader. 
It is, indeed, a question for the physiologist, rather than for the ornithologist.

It may seem that this attempt to answer the question, "What is a bird?" has taken us rather far afield. And on this account it may be well briefly to summarise the facts which have been gleaned on the journey.

In few words, then, a bird is a warm-blooded, egglaying feathered biped, having the fore-limbs modified to form wings, and the hip-girdle so adapted as to bring the hind-limbs far forward, to balance the body in walking on them alone. These characters, there can be no reasonable doubt, have gradually come into being by the slow transformations in a long chain of creatures, which, as we trace them back, are less and less bird-like, and more and more like reptiles. Though many links in this chain are yet missing, some day they will almost surely be found.

The evidence for this reptilian descent is abundant. Every bird, in the course of its growth from the egg, passes through more or fewer of the ancestral stages; and while some of these carry us back to phases of development which belong to ancient types of birds long since extinct, others carry us yet further, and show that modern birds and reptiles have descended from a common stock.

Feathers.-Though feathers are so common, few realise what marvels of structural beauty they are. Nor is the peculiar fashion of their distribution over the body even now generally recognised. Those who have spent their lives in the study of living birds need not be told that the feathers of a bird are not, as a 
rule, generally or evenly distributed over the body, after the fashion of hairs on a dog, for instance, but, on the contrary, are arranged in long and generally narrow bands, or "tracts," separated by wide, bare, or sometimes down-clad spaces.

The fact that these bands vary greatly in shape among birds was first realised by a German naturalist named Nitzsch, who made a long and careful study of the feather-tracts of birds. As a result of his patient work, he was able to show that the variations in this arrangement followed certain definite lines, each group of birds possessing a type peculiar to itself; and, for the purposes of convenient description, he gave these tracts distinctive names, which, in the main, are followed to this day.

Briefly, as a result of his work, he distinguished: (1) a head tract, formed by the feathers clothing the head; (2) a spinal tract, extending from the head down the back of the neck, and along the back to the tail; (3) a ventral tract, running from the throat down to the base of the neck, where it branches at the shoulders, to run down over the breast and abdomen in the form of two bands, a broad outer and a narrow inner band; (4) a pair of humeral tracts, which, crossing the upper arm, form the feathers known as the scapulars; (5) the wing tract, including the quills and wingcoverts; (6) the tail tract; (7) the femoral tracts, which run across the thighs; (8) the leg tracts, which cover the legs below the knee.

The most important of the variations which these tracts present are to be found in the spinal and head tracts. Thus, in the first-named, the spinal tract in 
the Swifts encloses a bare space over the middle of the back; while in the Swallows it divides into a fork in this region, leaving the hinder portion of the tract in the form of the usual straight band. In the Finch tribe the middle region of this tract is diamondshaped. The head tract, again, often encloses a space; as, for example, in the Humming-birds and Mouse-birds of Africa. The ventral tract similarly presents very marked differences when a number of different kinds of birds come to be examined.

Those who may be interested in this question should take, say, a Sparrow, Starling, Thrush, Pigeon, and Fowl, cut off the feathers with a pair of scissors, close to the body, and compare the differences between them. Since these differences are constant, and since each group presents a type of its own, it has been found that the "pterylosis," as this arrangement of the feathers is called, affords a valuable aid to the classification of birds. For example, the very wide difference in the pterylosis of the Swifts and Swallows was the first indication of the fact that these birds were not related, as they had always been supposed to be, and later anatomical investigations have given further proof that these birds belong to quite different groups.

In the Penguins and the Ostriches the bare spaces found in other birds are hardly traceable, in so far as the trunk is concerned, the feathers covering almost every inch of the body.

In describing the external appearance of a bird these tracts are commonly ignored, the body being 
mapped out into certain areas such as are indicated in Fig. 4.

So far we have spoken only of the feathers which form the outer surface-covering of the bird, the "contour" feathers, as they are called because they form the contour or outline of the body. But besides these there are no less than three other distinct kinds of feathers - d o w n feathers, filo- BREAST. plumes, and powderdown.

Dow $n$ feathers in many birds are conspicuous by their absence, and are developed most abundantly in waterbirds, such as Ducks, for example, growing not

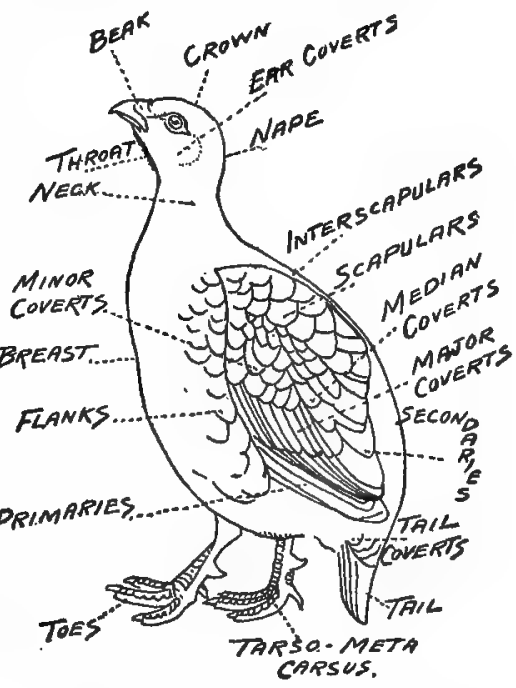

Fig. 4.-Diagram of a Bird, SHOWING THE DIFFERENT AREAS OF THE BODY. only between the feathers, but over the otherwise bare spaces as well, so as to form a thick undergrowth, answering to the under-fur of seals, for instance.

Filo-plumes appear to be present in all birds. They are the long, hair-like growths so conspicuous in the common Fowl when plucked. In some birds they attain such a length as to extend beyond the contour feathers, forming, as in some Cormorants, long, white, delicate plumes.

The powder-down feathers are found only in a few groups, such as the Herons and Bitterns, and some 
Hawks and Parrots. In the Herons and Bitterns they form large patches, a pair on the breast, and a patch over each thigh. Of a peculiar woolly appearance, they are remarkable for the fact that they break up, when touched, into a fine powder, which, when rubbed between the fingers, gives an indescribably smooth feeling. It is the powder from these remarkable feathers which gives the peculiar bloom to the beak of many parrots, as well as to the plumage. As to the real purpose of the powder, however, we know nothing.

This brief survey of feathers would not be complete without a few words as to their structural characters. In the typical feather (say, a quill-feather), two main parts are to be distinguished - the stiff stem, and the broad, flexible blade known as the vane, or vexillum. The stem may further be divided into the quill, or calamus, the hollow part below the vane, and the shaft or rhachis, which is flattened in section and filled with a white pith-like substance. The vane runs along on either side of the rhachis in the form of a series of tapering, flattened rods, the "barbs." They are set so closely together that they must be carefully sought for; and give to the vane that finely grooved appearance, or, rather, the appearance of a series of fine lines running obliquely outwards from the shaft. If an attempt be made to pull these apart, it will be found that considerable force must be used, and this is owing to the fact that they are locked together by a second series of flattened rods, known as barbules, so small as to require the microscope to reveal them. 
But the mechanism by which this vane is held together is so wonderful that it must be explained.

If you examine the blade of a feather with a magnifier, you will see that the vane is made up of small barbed feathery portions, which interlock one into another so as to be flexible without separating. In Fig. 5 a portion of this magnified area is shown as it appears when seen in a section still further magnified.

When the structure of a feather is examined under a microscope of high power it is seen that the barbs are themselves sub-divided along the edges into a marvellously constructed system of branches which are most wonderfully shaped so as to hook one into the other and to support one another under the great pressure of the air coming upon them during the motion of the wing in flight. Only a complicated set of diagrams and a long technical description could give the reader any adequate idea of its surprising mechanism. We can say here only that it is of almost unimaginable delicacy and strength. We earnestly recommend that the subject be studied in more technical books, as it will prove most fascinating.

Thus, then, this marvellous interlocking is the reason why it is so difficult to pull the barbs of a feather apart. In the vane of a Crane's quill, in a piece of web 15 inches long, no less than 650 of these barbs were counted, each of which bore about 600 pairs of barbules - that is, about 800,000 for the inner web alone, and more than a million for the whole feather: and all these are necessary to hold the vane together.

This system of interlocking is most perfect in the 
wing and tail quills. In some feathers, such as have a loose, hairy texture, as in the body feathers of many birds, these hooklets are but feebly, if at all, developed. The loose feathers of the Ostrich tribe also lack them, but even here they were at one period all perfectly

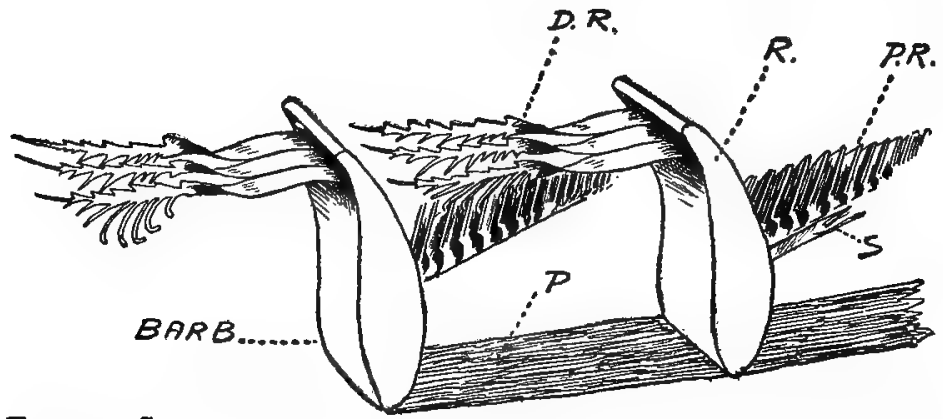

Fig. 5.-Section through tWo Rows Parallel to THE Distal RADII OR BARBULES. D.R., DISTAL RADII ; P.R., PROXIMAI RADII OR BARBULES.

developed; when the birds ceased to fly, the feathers degenerated, and the interlocking was lost.

What are known as semi-plumous feathers are imperfectly developed or changed feathers.

Down feathers differ considerably from "contour feathers" in structure, having little or no shaft, all the barbs arising from a common base. These barbs are, further, very long, and have only very minute barbules. In the Ducks and some other birds these barbules take the form of triangular nodules; while in other birds again they are knot-like.

The filo-plumes have a long, slender shaft with a minute vane at the tip. They are, apparently, a degenerate form of contour feather, judging from the fact that during the earlier part of their development 
many more barbs are present than are to be found in the fully grown filo-plume.

Yet another form of feather is that which is found fringing the mouths of birds like Flycatchers and Nightjars. Bristle-like, there will yet be found about the bases of many a few weak barbs; the eyelashes of many birds, like the Ostrich, the Ground-Hornbill, and some other birds, are similarly fringed with these peculiar bristle-like feathers.

The down which covers the nestlings of many birds, such as Fowls and Ducks, answers to the contour feathers of the adult, but is of a simpler structure; indeed, it differs in character among different species of the same group. In its most completely developed form it recalls the contour feathers, having a shaft and barbs with weak barbules, but these last have no distinct hooklets, hence the general loose character of down plumage; while in its more degenerate form the shaft is absent, as in a true down feather.

Where down is present in the adult, it will be found in the nestling just before the feathers begin to appear. In some birds, as in the Ducks, indeed, and young Hawks, these early down-feathers, or "preplumulæ," attain so large a size that they eventually play a more prominent part than the typical nestlingdown, or "pre-pennæ," so-called because preceding the pennæ, or feathers. In young Cormorants the nestling-down is wholly made up of these pre-plumulæ, which are succeeded later, not by contour feathers, but by down feathers.

Nestling-down in its most degenerate form may be seen in young Pigeons, and the young of most of the 
Song-birds; while in others it is altogether wanting, as in young Sparrows, and those of the Crow tribe.

Only in the nestling-down of the Game-birds, Ducks, and the Ostrich tribe is there found a formation of feathers known as the "after-shaft." This, by the way, is a conspicuous feature in the adult feathers of the Emu and Cassowary, where it forms a sort of duplicate of the main-shaft, equalling it in size; while among the higher birds it is never very large, except in the Game-birds (Fig. 6), but even here it is downy in texture, and is always shorter than the mainshaft.

As touching the growth of feathers, but little can be profitably said here. The earliest traces of feathers must be sought for in the embryo, where the first rudiments of the coming nestling-down appear in the form of tiny bead-like bodies, which soon sink down into a pit. Next an outer pro- VANE tecting sheath is developed around this feather rudiment, and within this the mass of pulp which it contains proceeds to form first the main axis, and next the b a r b s and barbules. What will prove the tip of the feather is the first to be formed, and as this forces its way up, the

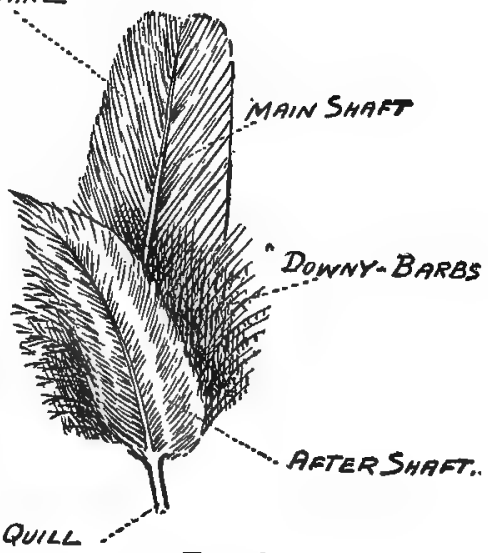

FIg. 6. lower parts are added, till at hatching-time the whole of the down feather is completed. 
At the base of this down feather lies the germ of the contour feather which is to follow. As this grows the down feather is thrust out upon the tip of the new contour feather, and here it may be attached for a very considerable time, as in the case of young Herons, for example. On its first appearance, the new feather is ensheathed in a thin, delicate blue wrapper, the first-formed portion of the vane bursting its way through while the lowermost portion of the feather is yet forming.

Moulting.-In most birds the feathers are renewed annually, by the process known as moulting-a critical time in a bird's life. When there is a lack of suitable nourishment, or when the bird is low in vigour at the moulting-season, the feathers become curiously indented with fine grooves known as "hunger-marks."

The annual moult takes place generally after the breeding-season; but some birds moult again in spring, when a new and more resplendent livery is put on, as in the case of many of the Plover tribe: But the quills in such cases are not renewed. In some of the Ducks, as in the drake of the common Wild Duck, a dull livery, resembling that of his mate, is assumedthe so-called "eclipse" dress-during the month of June, and this is worn for some weeks. By the middle of August the new and characteristic "breeding-dress" is well in evidence, and by October is completed. This "eclipse" dress, then, answers to the dull dress put on after the breeding-season by the Plovers, and is simply moulted again in a month or two instead of being worn till the following spring. Some of the Game-birds undergo a partial "eclipse" 
plumage, but this change is confined to the feathers of the head and neck.

While some birds put on a new and brightly coloured dress in spring, others brighten up their plumage quite as conspicuously by simply shedding the tips of the feathers assumed at the autumn moult. No better instance of this can be found than that of the Linnet, which, by this shedding process, gains the beautiful rich brown back, and rose-pink breast, that make these birds so much prized. For some as yet unexplained reason, however, captive birds, if taken in July, before the autumn moult, develop yellow in the place of red-which colour is never regained; if taken in the autumn, the red breast appears in the following spring, but never again. The beautiful plumage of the Starling is similarly attained by this method of shedding the outer edges of the feathers, and the Chaffinch gains its blue head in the spring by this same process.

Whether birds can gain an access of colour to the feathers without a moult is still a disputed point. Some hold that there can be no doubt about the matter; while others, apparently as well qualified to speak on the subject, deny the possibility of such a change absolutely.

That the colour of feathers can be influenced by feeding is a fact too well known to need further comment; but it may be interesting to remark that this fact is well known to the savage people of Brazil, who feed a species of green Parrot on the fat of Siluroid fishes; the feathers, as a consequence, becoming beautifully variegated with red and yellow. Another race 
of South Americans change the colours of Parrots by plucking out such feathers as they propose shall be altered, and inoculating the spot from which the feather was taken with the milky juice obtained from certain glands of a small toad. The new feathers now appear of a brilliant yellow colour, and on being plucked out, it is said, grow again of the same colour without any fresh inoculation. It taxes human ingenuity to account for savages making such a discovery.

Beak and Feet.-Finally, let us consider the covering of the beak and feet. The jaws of a bird, as we have already remarked, no longer bear teeth, but are ensheathed in horny cases. In many species, as in the Petrels, for example, the beak-sheaths, instead of being entire, one for the upper and one for the lower jaw, are made up of a number of separate pieces; while in the Puffin, and one of the Pelicans, ornamental plates are developed during the breedingseason and shed immediately after. In the Pelican this plate is square in shape, and borne on the ridge of the beak near its middle; in the Puffin it is triangular, and is attached to the base of the beak at each side.

The legs, to use the common term, as a rule are covered, as in the reptile, by horny scales; but in some birds, as in Grouse, and Sand-grouse, and the Golden Eagle, and many Owls, the shank of the legs, and often the toes also, are covered by long feathers not unlike long, silky hairs, and quite different in character from the quill-like feathers on the legs of the 
domesticated races of Pigeons and Fowls. In some birds a delicate skin takes the place of scales.

The claws of birds vary greatly in shape, according to whether they play any part or not in the capture of the food. Thus they may attain a relatively enormous size in Birds of Prey, where the claw of the hind-toe is especially large; here the feet are used to hold living prey securely. Some species, indeed, as the Goshawk, for instance, kill their prey by means of the feet and claws. In the Jacanas, birds of the Plover tribe, the claws attain an enormous length, forming long, pointed rods, which with their tremendously long toes serve to enable them to walk on the delicate floating weeds of the rivers which these birds haunt. In some other birds, as for example in the Cassowary, the claws may be used as a weapon of offence. In this bird the inner claw is of great size and strength and is capable of inflicting a very dangerous wound.

In many of the Grouse tribe the claws are shed each spring; though in some, as in the Black Grouse, the shedding is confined to the ragged fringe along the inner side of the claws. This fringe, by-the-bye, recalls the fact that the middle claw in many birds, as the Barn Owl, Nightjar, and Herons, for instance, has a curious series of little teeth running along its outer edge; but so far no one has been able to tender any suggestion as to what purpose it may serve.

Finally we must find space for a brief reference to the formidable weapons which many birds possess in the shape of spurs. These are generally confined to the legs, and may be represented by a pair only, as 
in the Game-cock, or by several, as in the Peacockpheasant. But, beside these, a few birds have a similar, and equally powerful, armature in the wings. In some, as on the "Screamers" (Palamedea and Chauna), two spurs are developed, one at each end of the fused metacarpal bones-the bones which form the "palm" of the hand; in all other birds but one spur is developed, and this may spring from one of the wrist-bones, as in the Spur-winged Goose, or from the base of the thumb, as in the Jacanas.

Flight and its Mechanism.-While, in the possession of feathers, birds are unique in the animal kingdom, they are not to be so distinguished in the matter of flight, for many creatures even far below them in the scale of life have this most enviable form of locomotion; while the Bats, which belong to man's own class - the Mammalia - on the other side of the scale, are also adepts in the art. In the manner of their flight, at any rate, the birds are peculiar.

In the study of "the way of the bird in the air," it is difficult to know where to begin, and having made a beginning, it is by no means easy to tell a plain, straightforward tale. Though birds are essentially flying animals, and though to attain this power they have become profoundly modified as to their bodily shape, they have yet, in some respects, not gone so far as, say, the Bats. The latter have almost completely sacrificed the power of walking, while birds have, with some few exceptions, preserved this. Let us come to closer terms with our subject by a study of the bony framework of the body in its relation to flight. 
The whole body is brought into harmony with the requirements of flying. The long neck, passing insensibly into the body, which tapers again into the tail; and the beautifully smooth, rounded surface formed by the close-fitting overlapping feathers, offer the least possible resistance to the air; while the large mass of the breast-muscles attached to the under surface of the body - which during flight is, as it were, slung between the wings - contribute toward the right ordering of that all-important matter, balance. In many birds special means have been adopted to secure extreme rigidity, as may be seen by the fact that the separate vertebræ of the back have become welded together to form a stiff, unyielding beam. But it is not until we come to examine the bones of the shoulder-girdle and sternum, and of the wings, that we find the modifications of the skeleton which flight has brought about.

By the shoulder-girdle is meant those bones which make up the shoulder-blade, or scapula; the long, straight pillars known as "coracoids," and the furcula, or "merry-thought." These form a sort of cage fixed on to the front of the sternum, or breast-bone. This bears, as everybody knows, a rough resemblance to the hull of a ship, with an extremely deep keel. A reference to the figure here should make this clear. The deep keel and the broad, flat plate of the breastbone serve for the attachment of the breast-muscles, which in the bird are of enormous size, equalling or exceeding in weight all other muscles of the body.

These muscles, which constitute the large mass of flesh familiar to every one as the "breast-meat" of a 
bird as served at table, are arranged in two layers. The outermost runs forward, to be inserted into a shelf of bone which projects from the upper surface of the humerus, or upper arm; while the lower runs

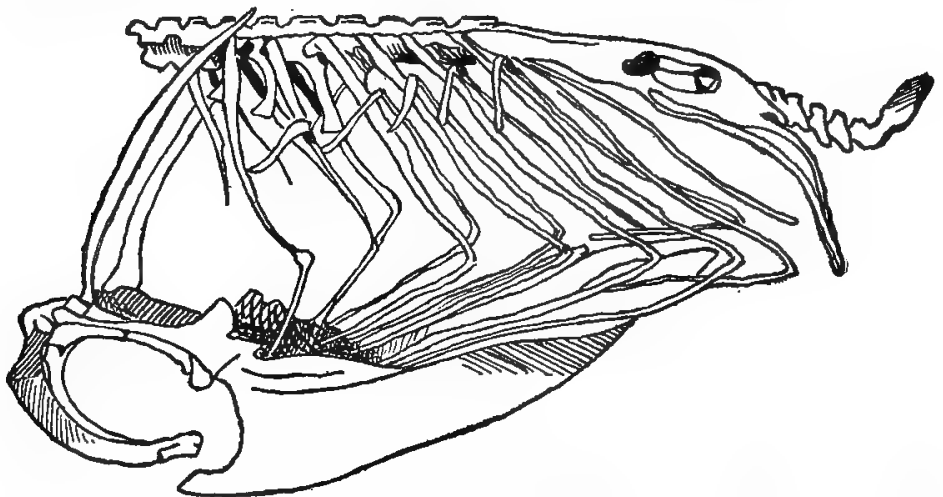

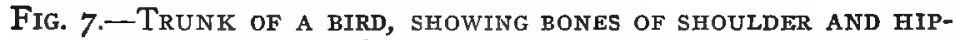
GIRDLES.

beneath it, along the coracoid, and finally passing into a round tendon, runs through a pulley formed by the meeting of the coracoid, blade-bone, and merrythought, and into the head of the humerus. These two muscles play the most important part in raising the body and keeping it in motion, for these, by their contraction, bring about the downward wing-beat. The other muscles which aid in this work, and those which raise the wings at the end of the stroke, need not be studied here. How intimately the keel is associated with flight may be seen by an examination of birds which fly but little. In them the keel is always shallow, while in those which have lost the power of flight altogether it is reduced to a mere ridge of bones, as in the Owl Parrot (Stringops), or has vanished altogether, as in the flightless Ostrich tribe. 
The wing itself is no less profoundly modified, as we pointed out in an earlier part of this chapter. Suffice it to say here, that of the original five fingers but three remain. Of these the thumb and third finger are reduced, and little more than stumps; while the second finger has been elongated to form a long, rigid rod, strengthened at the base by that portion of the third finger which in ourselves contributes to form the "palm" of the hand. In the bird's palm there are but two bones, forming the base of the second and third fingers respectively.

The bird's wing folds in a peculiar manner, so as to form a more or less Z-shaped rod, the humerus, or

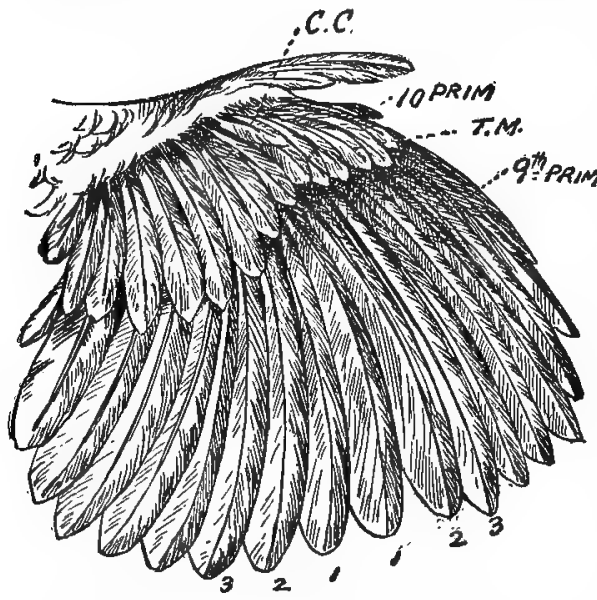

Fig. 8.-Wing of a BIRD, Showing the

FLIGHT FEATHERS AND SOME OF THE COVERTS. upper arm, forming the top of the $Z$, the fore-arm the downstroke, a n d the hand the base of the $Z$.

When extended, each of these divisions or segments, will be found to support a series of long, broad feathers. Those on the hand are known as the primaries, and those on the fore-arm as the secondaries, while those on the upper arm are sometimes described as the tertiaries. These last form a double series, one attached to the upper and one to the under 
surface of the humerus, or upper arm-bone, and their purpose is to close the gap which would otherwise be left between the wing and the body during flight-a gap which, indeed, would make flight well-nigh, if not quite, impossible in birds which, like the Albatross, have a long humerus. Above the "quill" or "flight" feathers - the primaries and secondaries-will be found a number of rows of smaller feathers, which can be divided into several distinct series. These are the "coverts," and are known respectively as the major, median, minor, and marginal coverts. Of the first and second series - the major and median coverts - there is but a single series; while the minor coverts and marginal coverts number several rows each. Some of these smaller coverts have, for clearness's sake, been removed in the accompanying diagram. The row marked t. m. is formed by the major coverts, or tectrices majores.

The manner in which the feathers of the wing overlap one another is a matter of some importance to those who are engaged in the work of classifying birds, and in the mechanism of flight is even more important. If the wing of any bird be examined, it will be found that the free edges of the "quill" feathers and of the major coverts are turned outwards-towards the tip of the wing; while more or fewer of the other coverts have the free edges turned towards the body. Consequently, when the wing is raised the wind forces its way easily between the feathers, and so offers the least possible resistance to the upstroke; but during the downstroke the wing affords an unyielding surface, and so forces the body upwards and forwards 
at each stroke. Compared with the Bat's wing, the wing of the bird is a vastly superior organ, and for this reason: The wing of the Bat is formed by a membrane stretched between long, slender fingers, so that any serious injury to this membrane permanently disables the creature. 'The bird's wing, on the other hand, has its flying membrane formed of a number of overlapping, elastic, ribbon-like structures - the quills - which are periodically renewed, and can be replaced if injured.

Organs of Digestion and Air-sacs.-Though once upon a time birds had teeth, they long ago solved the problem of doing without them. Like the Tortoise and the Turtle among the reptiles, birds have replaced their teeth by horny sheaths which encase the jaws, and these sheaths take many forms. As a rule, that of the upper differs but little from that of the under jaw; but in many birds this is not so. In the Birds of Prey, for example, which tear their food in pieces, the sheath of the upper jaw is hook-shaped; and this is true also of the Parrots. Birds which seize rapidly moving and slippery prey, such as fish, have spear-shaped beaks, as in Herons and Kingfishers; and a similar weapon is developed where a rapid succession of blows is rained upon hard, unyielding surfaces, as in the beaks of Woodpeckers, which, moreover, have the density of the horn immensely increased. On the other hand, these sheaths are often of great delicacy, as in the case of the Snipe and Woodcock, the fragile, upturned beak of the Avocet, or the long, rod-like probe of many Humming-birds. In the so-called soft-billed birds, the jaws serve 
merely as light forceps, and, consequently, they and their sheaths offer no very striking characters; while in Swifts, Swallows, and Nightjars the beak has become reduced to the

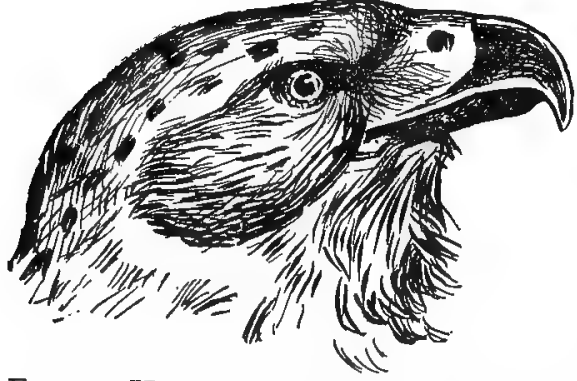

Fig. 9.-Head of a HaWk, showing THE HOOK-SHAPED BEAK USED FOR TEARING PREY. smallest possible limits because the jaws perform but little work in seizing the food. When slippery victims have to be held, such as fish, the edges of these horny sheaths are armed with saw-like teeth, as in the Mer-

gansers among the Ducks; or these teeth may take the form of needle-like spines, as in the Darters. In the Ducks and certain Petrels, horny plates, resembling the baleen-plates of "whalebone" Whales, are developed, and these serve as sieves, or strainers, allowing the water taken into the mouth with the food to escape, leaving the solid matter behind.

This horn-encased region of the jaws forms the "beak," and the shape of this is determined by the nature of the bird's food.

From the mouth the food is passed down the gullet, or oesophagus, until, in many birds, such as Pigeons and Fowls, it reaches a special dilatation of the gullet known as the "crop." This is a thin-walled bag, wherein the food is stored and softened, preparatory to being passed on to the stomach. This, in birds, consists of two parts, one lying in front of the other. 
The first, which is superficially hardly distinguishable from the gullet, is known as the "proventriculus." Its walls are richly supplied with digestive glands. From this first stomach the food passes into the second, which, in birds such as Fowls and Pigeons, for example, has extremely thick and muscular walls, while its cavity is lined with a more or less dense skin, thrown into a series of folds. A stomach of this kind is known as a "gizzard"; but in birds which feed on animal food, such as Hawks and Gulls, there is no gizzard, the walls of this region of the stomach being thin and soft. Where a true gizzard is developed, sharp stones and sand are swallowed by the bird, and these are stored in the gizzard to aid in the work of grinding up the grain and other hard matter, which form the bird's food. Even flesh-eating birds appear to find it necessary to swallow indigestible matter with their food, and this matter is furnished by the hair and feathers of their victims. Digestion completed, the indigestible residue becomes welded together into a mass, and is ejected from the mouth in the form of a "pellet." From the second stomach the food passes on into the intestine, and here all the nourishing portions are absorbed.

The air-sacs are found in all birds. They take the form of a number of thin-walled chambers lying on the sides of the body, and in front of the merrythought. During life these chambers are filled with air drawn from the lungs. They are really a part of the lungs; but their precise structure need not be described here. At one time it was thought these great air-chambers served the purpose of decreasing 
the weight of the bird during flight; but this is now known to be an incorrect view. They serve to assist respiration, and also, probably, to regulate the temperature of the body.

Concerning Eggs.-Birds, like their cousins the reptiles, and certain low forms of mammals, lay eggs. In birds these are always invested in a hard shell, which is commonly coloured, often very beautifully. How this colouring is formed, and how deposited on the shell, we do not yet know, or at least only in part.

The number of eggs laid by different species of birds varies greatly. Thus some species lay but one egg, as the Guillemot; some two, as the Pigeon. Plovers lay four, Game-birds from twelve to twenty.

When first formed the egg of a bird is extremely small, but during its development there is added to the germ, which is to grow into the chick, a great quantity of yolk, to serve as food for the developing bird, and outside this food-yolk there is deposited a quantity of "white" of egg, and, finally, the whole mass is enclosed within the shell.

Although certain stages of development are passed before the egg is laid, this development is soon suspended, and is only resumed as a consequence of the heat generated by the body of the brooding bird.

When hatched, the young birds are in many species extremely active, following their parents and finding food for themselves soon after leaving the shell; in other species the young leave the shell in a singularly helpless condition-blind and naked - and these have to be very carefully attended by the parents until they are strong enough to fly and take care of themselves. 


\section{PUBLISHER'S NOTE}

THE color-plates for this work have been engraved after designs by a German artist. Since they were printed, with the accompaniment of the common and scientific names, careful verification of these names has been made, in consultation with some of the leading zoölogical authorities. As a result, the attention of the reader is called to the names of the birds mentioned in this note. This list contains names correcting typographical errors in the same names as they appear under the pictures to which they belong.

\section{Plate 2, Fig. 5: Gypagus papa.}

\begin{tabular}{|c|c|c|c|c|}
\hline & 3, & $"$ & 12: & European Sparrow Hawk. \\
\hline & 4 & $"$ & 17: & European Red Kite. \\
\hline & 8, & $"$ & 37: & Blue-fronted Amazon. \\
\hline & 10, & " & 48: & Chasmorhynchus nudicollis. \\
\hline & 11, & $"$ & 54: & European Blackbird. \\
\hline & 13, & $"$ & 71: & White-throat (Sylvia cinerea) \\
\hline & 16 , & $"$ & $92:$ & Pine Grosbeak. \\
\hline & 17, & $"$ & 95: & Paradise Whydah-bird. \\
\hline & 17, & $"$ & 96: & Sporceginthus amandava. \\
\hline & 25 , & $"$ & 145: & $\underset{\text { Rliv }}{\text { Red-legged Rock Partridge. }}$ \\
\hline
\end{tabular}




\section{BIRDS OF THE WORLD}

\section{CHAPTER I}

The Ostrich-Like Birds

\section{O R D E R S - CASUARII, STRUTHIONES, APTERYGES, AND CRYPTURI}

A LTHOUGH lowest in the matter of intelligence, the Ostrich tribe are among the most interesting of birds. In the first place, they are the survivors of a much more ancient type, extinct long before the advent of man upon the earth; and in the second, they have undergone most profound changes in their anatomical structure.

To begin with, all save the Tinamous of South America have absolutely lost the power of flight, and at so remote a period that the great keel of the breastbone, to which we have already referred, has entirely disappeared. But, besides this, the wings have degenerated to an extent met with in no other living birds; and this is true also of the feathers.

The first member of this Order to be considered is the Emu, of Australia, the home of so many strange forms of animal life. Next to the African Ostrich, the largest of living birds, the Emu has little to distinguish it in the matter of beauty, its coarse-looking 
plumage being dull-greyish in colour. The wings are extremely small, and can be found only by diligent search among the feathers of the sides of the body. It is a singular-appearing bird, owing to the long, hairlike feathers, and when viewed from the front the eyelashes sticking out on each side of the head give it a very fierce expression.

Two species of Emu are generally recognised, both inhabitants of Australia and neighbouring islands. The bird is easily acclimated in England, and is quite common in many of the parks of that country, where it is allowed to run at large. It breeds remarkably well. The eggs are solidly coloured, a deep bluishgreen at first, which gradually changes to black. The young are prettily striped little creatures, looking quite unlike the parent birds. The Emu has three toes, and, like other members of the Ostrich family, is able to deliver a very powerful kick.

The sober-coloured Emu has some very handsome relatives in the Cassowaries of New Guinea and the neighbouring islands - though one species occurs on the mainland of Australia. But little is known about these birds, however, in the wild state. When first feathered they are like the Emu in colour of plumage, but when adult life is fully attained they have a rich shining black coat, much resembling hair. At maturity they shed the feathers of the head and neck, the bare skin then assuming the most brilliant huescombinations of blue, green, violet, red and yellow, according to the species. From the crown of the head there arises a large casque, or helmet, which, though it looks solid, is really a very frail structure, consist- 
ing of a mass of delicate lacework of bone encased in a thin sheath of horn.

The general appearance of the Cassowary is well seen in the illustration. The curious spikes projecting from the sides of the body are all that remain of wing-feathers, while the wing as a whole, is like that of the Emu, extremely small and degenerate. The "hand" is so reduced that it cannot be bent back at the wrist, as in birds that have the power of flight, and the thumb is quite lost, as in the Emu. The only finger that is left is provided with a long claw. Cassowaries are further remarkable for the fact that the inner toe bears an enormous claw, which is used in fighting-forming indeed a very formidable weapon. The legs are short and thick. The sexes are coloured alike, and the neck is adorned with brilliantly coloured wattles, or excrescences. Altogether, fifteen species of Cassowaries are known, one of which almost equals the Emu in size, standing as much as six feet in height. See Plate 28, Fig. 159.

The Emu and the Cassowary differ from all other birds in that the feathers are double-that is to say, each has two shafts, of equal size.

In Australia and Tasmania many remains of gigantic fossil birds are found, related to the Cassowary, one of which, the Moa, stood ten or twelve feet in height, dwarfing in size the largest Ostrich. Remains of these birds in a perfect state of preservation have been found. A fossilised egg of the Moa, of enormous size, has also been discovered. Another great bird, Epyornis, closely allied to the Cassowary, probably lived at the same time as the Moa, and, judging 
from the condition of the fossil remains, these birds must have existed until comparatively recent times. The egg of Epyornis was the largest ever known, being several times the bulk of an Ostrich egg.

The Rhea, or South American Ostrich, though smaller than either the Emu or Cassowary, is yet a very large bird. It is remarkable, among other things, for the relatively large size of the wings, which are extended when running to act as sails, though they are far too feeble to raise the body off the ground. The loose structure of the feathers of this bird forms another bar to flight. The sexes are nearly alike in colour, both being a light purplish-grey, and there is little difference in the plumage of the young and the fully adult bird. Like its relatives, the Emu and the Cassowary, the Rhea has three toes, all placed at the front of the foot. As in the case of the former birds also, the male undertakes the duties of incubation and the care of the chicks. Several hens combine and lay their eggs in one nest, so that the male is at last left to brood about twenty eggs. These are golden yellow in colour, in contrast to the eggs of the Emu and the Cassowary, which are a beautiful green. Some specimens of this bird in the Zoölogical Park, at Washington, had the curious habit, when angry or excited, of crouching upon the ground and spreading' out their wings to the fullest extent.

The natives of South America pursue the Rhea on horseback and capture it by hurling the bolas-stones fastened to the ends of lines which are hurled by the hunter and twine around the legs of the birds, quickly bringing them to the ground. See Plate 28, Fig. 158. 
28.

159. Helmeted Cassowary (Caszurius yaleatus).

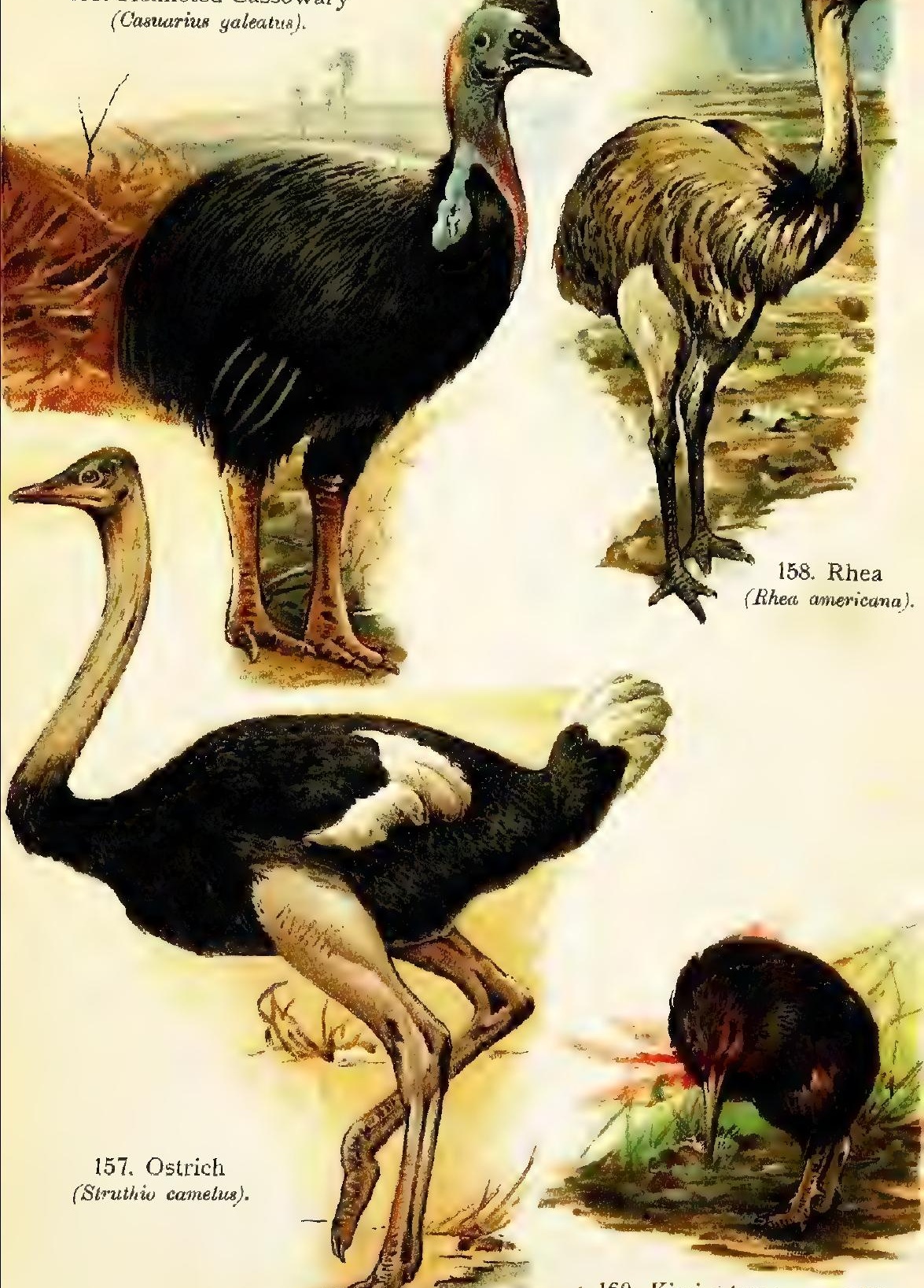



The voices of all the Ostrich-like birds are rather singular, consisting of a deep booming note uttered with the mouth apparently closed, and seeming to come from the chest.

The African Ostrich is the giant among living birds, the male standing some eight feet high, and exceeding the female in size, wherein he differs from the other Ostrich-like birds so far described. The African Ostrich is also unlike all his relatives in that he is conspicuously different from his mate in colouration, having the body clothed in a livery of glossy black, relieved by the pure white of the wing- and tailfeathers, which are the plumes so highly prized for millinery purposes. The head and neck are almost bare of feathers, while the massive legs are absolutely naked. The plumage of the female is of a sober brown hue. In the possession of a tail the African Ostrich is also peculiar among his tribe. As in the Rhea, the wings are of relatively large size, and, though useless for flight, they are of much assistance when running, being made to serve as sails.

The Ostrich stands alone among birds in the structure of the foot, which has the toes reduced to two in number; and of these one is so small as to play but a slight part in supporting the body. It runs with great swiftness, and is able to kick with terrible effect.

Like the Emu, the Ostrich has very long eyelashes, a singular character and one not often found in birds. The eyes are extremely large and bright, but stupid in expression, and indeed the bird is of a low order of intelligence. The Ostrich's habit of swallowing all sorts of indigestible substances is well known, and in 
the stomachs of dead birds have been found such strange objects as a china doll, a horn comb, pieces of glass, and small tools. For the same reason our domestic poultry swallow pebbles-in order to grind their food.

The Ostrich further differs from his relatives in that both sexes share the work of incubation; and here the difference in plumage plays an important part. The female, with her dull, sandy-coloured dress, sits by day, so that she is practically invisible when seen against the arid wastes chosen for the nesting-site. The male sits by night, when his dark plumage renders him invisible also. Like the Rhea, the Ostrich is polygamous, and several hens lay their eggs together in the same nest. See Plate 28, Fig. 157.

Though four distinct species of Ostrich are recognised by ornithologists, they do not differ greatly in appearance one from another, except in the colour of the legs, one of the South African forms having skin of a reddish hue, while the species found in Somaliland has dark bluish-grey thighs. These great birds are often found in company with herds of antelopes and zebras.

In all the Ostrich-like birds so far described, the nestlings are striped with broad bands of white and black, or brown, which run from head to tail. This striping is, however, not equally well marked in all the species. It is most clearly seen in the young of the Emu and of the Cassowary. In the young Ostrich the neck is striped, but the down of the body shows no stripes, these being obscured by the tips of the 
down feathers, which are transformed into little, horny curls, resembling dark, narrow shavings.

Ostriches are now raised on farms in various parts of the world. The largest of these farms are in South Africa, but in recent years some have been started in Arizona and California, where the birds thrive well. The feathers are clipped regularly at certain seasons of the year, the birds, which are blindfolded, suffering no injury in the process and offering no resistance.

Of the Apteryx, or Kiwi, of New Zealand, there are several species, that figured being known as Mantell's Apteryx. All agree in being soberly coloured, some having a freckled or mottled appearance like that of Plymouth Rock Fowls. The legs are short and stout, and the bird is able to run with great swiftness, depending, indeed, upon its speed for safety, since it is flightless. It can also deliver a strong blow with its feet, like other members of its tribe. The Apteryx is the smallest of the Old World Ostrichlike birds, not exceeding a large Domestic Fowl in size, and the female is said to be somewhat larger than the male. See Plate 28, Fig. 160.

Nocturnal in habits, the eyes of the Apteryx are exceedingly small; but deficient sight is amply compensated by a wonderfully developed sense of smell, in which it is believed to excel all other birds. Besides this, the region of the face in front of the eyes is provided with long hair-like feathers, which, like the "whiskers" of the cat, probably serve the purpose of feelers. This bird is also remarkable for the fact that its nostrils are placed at the extreme tip of its 
beak-a unique character. This curious position enables the bird to find its prey, which consists of worms and grubs. They are discovered by thrusting the beak down into the soil and sniffing for the odour of the desired dainties.

While the wings of the Apteryx are reduced to the merest vestiges, yet, as in the case of its relatives, a large claw is retained on the tip of the only finger that remains.

Though silent by day, the Apteryx is by no means so by night, giving forth piercing squeals that can be heard for long distances. In this way, doubtless, it finds its mate. The list of the peculiarities of the Apteryx is not yet exhausted; for it is remarkable for its enormously large egg, only one of which is laid in a season, and which, in proportion to the size of the bird, exceeds all other eggs in bulk. Within a very few years the Apteryx will probably be as extinct as the Dodo, owing to its destruction by stoats and weasels, which have, most unwisely, been introduced into New Zealand.

Sometimes placed in a separate Order, but often included in the Ostrich-like birds, is the Tinamou, found only in South America. Unlike the other birds described in this chapter, the Tinamou has a keeled sternum, but in very many other characters it agrees with them. It is Partridge-like in form, and for a long time was classed among the Game-birds, whose place it takes in South American countries. Sixtyfive species of Tinamou are recognised, varying considerably in size. The head is small, the bill rather long, the wings short and rounded, as in the Quail 
and Grouse, the tail-feathers short. In colour they are inconspicuous, usually greyish-brown above and mottled below. The nest is made in hollows in the ground, the eggs vary in number and in colour, and arc incubated by the male. The eggs are remarkable for their very high polish, looking like burnished metal, or porcelain. Like other ground-birds, Tinamous are difficult to flush, but when well on the wing are powerful and swift flyers. Mr. W. D. Hudson says "the whir of their wings can only be compared to the rattling of a vehicle driven at great speed over a stony road." See Plate 41, Fig. 240. 


\section{CHAPTER II}

The Carinate or Keel-breasted Birds, and Their Chief Peculiarities

$7 \mathrm{HE}$ birds to which the rest of this volume is to be devoted all differ from the Ostrich tribe, not only in the formation of the skull, but also in that the breast-bone bears a deep plate, or "keel," which runs down the middle of its under surface. In

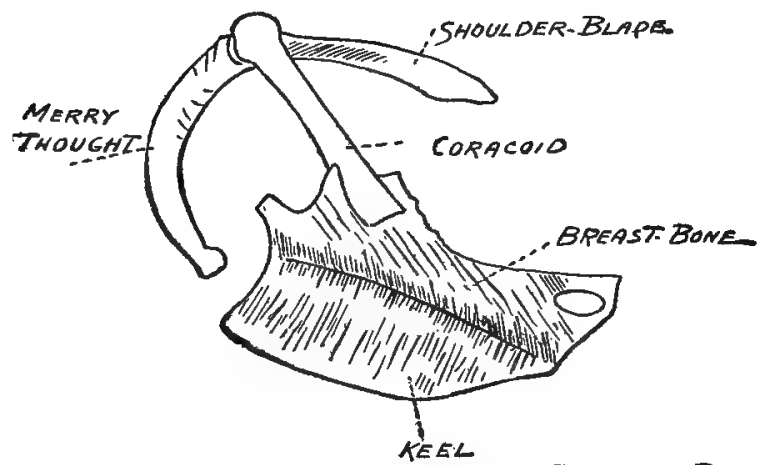

Fig. io.-The shoulder-girdle of a Carinate Bird TO SHOW THE KEEL OF THE BREAST-BONE, THE LARGE MERRY-THOUGHT AND SEPARATE BLADEBONE.

addition to this, the bones which are charged with the support of the wings are different, not in kind, but in degree. With the loss of the power of flight which we remarked in the Ostrich tribe, these "shoulder- 
girdle" bones, as they are called, degenerated. As a consequence, the blade-bone became immovably fixed to its supporting pillar, the "coracoid"; and the furcula, or "merry-thought," disappeared altogether, or left, at most, but slight traces of its former existence in the Emus. But with the flying birds the bladebone is joined to the coracoid by elastic ligaments, and the furcula, or "merry-thought," is well developed.

There are certain exceptions to this rule, however; and these occur in the case of some species which have, like the Ostriches, lost the power of flight. Herein the keel of the breast-bone has become greatly reduced, while some birds which yet retain the power of flight have either a very imperfect merrythought or none at all.

Flying-birds further differ from the Ostrich tribe in that their feathers are more perfectly developedthey only, in short, possess typical feathers. The distinctive characters of these have already been described in the introductory chapter.

Birds, like all other living creatures, compete one with another for food; and hence a given area of ground can support only a limited number of birds. All above the number which can find support in this area must either starve or seek fresh feeding-grounds, or contrive to find other kinds of food in the congested area. And it is this struggle to live which has brought about the marvellous variety in the forms of birds. For as new kinds of food and new methods of feeding were adopted, slow changes of shape in body, beak, wings, and feet came about through the 
process known as selection. That is to say, birds which, by some peculiarity in their structure, found themselves able to capture and thrive upon the flesh of other animals, including other birds, went on competing among themselves for this particular kind of food, and those which were best endowed-that is to say, those which by their longer wings or sharper beak and claws, or by their ability to swim and to divegradually crowded out their less fortunate fellows. As time passed, the peculiar characters and qualities. which originally gained for them superiority over their neighbours went on increasing, because the competition continued, being rendered, indeed, the more severe because carried on between fewer rivals-but rivals almost equally well fitted for the struggle. And thus, in course of time, by slow degrees, the various forms of birds have come to be. To-day, as a result, we find such differing types as Diving-birds and Treeclimbers, Hawks and long-legged Waders, and so on.

These different kinds of birds we group together in assemblages which are known as "Orders," and these are further sub-divided into Sub-orders, Families, and Genera, until finally we come to the division into species. In this way we can sort out and bracket together all kinds of birds according to their relationship one to another.

While some Orders are made up of birds which have retained a relatively large number of characters that are certainly survivals of very ancient times, and are hence said to be primitive, others have undergone great changes in structure and show many signs of descent from the less modified, less changed forms, and 
these are accordingly to be regarded as higher in the scale of evolution. The natural order, therefore, is to work upwards from the lowest, or more primitive, types to the highest, or latest evolved forms. The lowest of all, the Ostrich tribe, have already been considered, and we proceed now to a brief study of the higher forms of bird life. 


\section{CHAPTER III}

\section{Diving-birds, Petrels, and Penguins}

\section{ORDERS-PYGOPODES, TUBINARES, AND IMPENNES}

The birds which form the subject of this chapter are all aquatic in their habits, and feed upon fish.

\section{THE DIVING BIRDS}

THESE are divided into two groups: Sea Divers, or Loons, and Fresh-water Divers, or Grebes. The largest of the Sea Divers is the Blackthroated Diver, or Loon. This bird breeds in Iceland, Greenland, and the Fur Countries of North America, as far west as the Great Slave Lake. It lays two eggs, olive-brown in colour, spotted with black, any convenient place on the ground near the water's edge serving for a nest. See Plate 39, Fig. 231.

Though these birds are commonly called Sea Divers, they show great preference for fresh water, breeding and passing the summer months in inland waters. During the winter, however, they retreat to the sea, and there disperse along the coast. This migration is probably due to the necessity of keeping to open water, for, being entirely dependent upon fish for their subsistence, severe frosts immediately cut , 
off the supply of fresh-water fishes in their chosen haunts.

The Loon is so called on account of the strange cry it utters, suggesting the laugh of a maniac; at other times its voice has a piping, resonant sound. When swimming under water, the wings are not used, the Loon depending for progression entirely upon the strokes of the feet-in which it differs from the Penguins, to be described later.

The adult male is very beautiful in summer plumage. The head and upper part of the body are a deep greenish-black, velvety in texture, and the breast is silvery white. Over the back and around the neck are numerous spots and lines of pure white, giving much the effect of lace over the dark green; the eye is a deep blood-red.

An individual of the Common Loon, caught in a fish-trap off the coast of Massachusetts, was kept for some months in a pool belonging to the Fish Commission Station at Woods Hole. Extremely shy at first, for several days it would come to the surface of the water at intervals, remaining only long enough to breathe before diving again. Within a week, however, this Loon became ridiculously tame, and would allow itself to be lifted from the water with as little resistance as a wooden decoy. Although the pool was more than a hundred feet in length, there was not sufficient distance for the bird to rise in the air and fly over the low stone wall surrounding it, since these birds require a long "start" in order to get on the wing. Once fairly launched, however, they are powerful and swift flyers; but on land they are ex- 
tremely awkward, owing to the position of the legs at the back of the body. The Loon referred to was supplied with living fish from the aquariums at the Station, and it was most interesting to watch it pursuing them under water. It would catch the smallest fry with remarkable quickness and dexterity, never seeming to miss one of its finny prey. When given a fish too large to swallow with ease, the Loon would pound and thresh it about, gradually softening it until in condition to be devoured. The amount of food required by this captive bird was extraordinary; after despatching twenty-five or thirty minnows in quick succession, after a very short interval it would be ready for as many more.

The Red-throated Loon is a smaller species having much the same range, breeding in the far north and migrating southward in winter.

Fresh-water Divers, or Grebes, are found in nearly every part of the world, although they are most common in temperate regions. While the Sea Divers have fully webbed feet, the Grebes simply have the toes provided with broad lobes. But both Grebes and Divers are experts at swimming under water. So completely have the Sea Divers become modified by this mode of life, that the legs have become shifted to the extreme hinder end of the body, and, as a consequence, they cannot walk. The Grebes, however, can do so, although awkwardly.

Two species of Grebe are figured here, the Great Crested Grebe and the Little Grebe, or Dabchick. The former is a very handsome bird, and was at one time much hunted for the sake 

of its breast feathers, which were made up into muffs and other ornamental articles of dress. This bird is remarkable for the wonderful frill which surrounds the head. This is a rich dark chestnut in colour, shading at the edges into a very dark brown, and can be raised or depressed. In addition, long "horns," or tufts of feathers, spring from the crown of the head. The sexes are similarly adorned, but in the males these ornaments are more developed than in the females. A curious thing about the Grebes is the fact that they build floating nests of weeds, sometimes attaching them to rushes and reeds growing in the water. The eggs vary in number from three to six, and are white at first. but gradually change to brown. See Plate 39, Fig. 232.

The Dabchick, or Little Grebe, is a much smaller bird, which in summer has the cheeks, throat, and sides of the neck a rich chestnut colour, giving place to a silvery white in winter. It ranges over Europe, Africa, and Asia, extending from the Malay countries into North Australia. See Plate 40, Fig. 237.

Two species common in America and frequently confused are the Horned Grebe and the Pied-billed Grebe. The former is distinguished by large tufts of feathers which stand out on each side of the head. It is seen along our coasts during the spring and fall months but is not so common as the other species mentioned. The breast is glistening white, and in flight the white patch on the wings is a conspicuous mark. This bird winters throughout the United States, breeding northward. 
The Pied-billed Grebe, commonly called Hell-diver, has also a very extensive range, being found at different seasons of the year in both North and South America. It swims and dives with the greatest ease, often swimming under water with only the tip of the bill exposed. In summer this bird is dark greyishbrown above, lighter below, and has a black band across the bill. In the fall the upper parts are darker, the breast and sides are brown, and the rest of the under parts silver-white.

\section{Petrels, or Tube-nosed Birds.}

The Petrels are strictly sea-birds, having webbed feet, and all are peculiar in that the nostrils open, either in the form of a pair of tubes, one on each side of the beak, or into a cavity on the top of the beak: hence the name, "tube-nosed" birds. The wings of the Petrels are long and pointed, and their powers of flight are remarkable. They practically live at sea, seldom coming to land except during the breeding time.

Of the many different kinds of Petrels, three species are figured; and of these by far the most interesting is the Albatross, one of the largest birds that fly. The Black-browed Albatross is found in Europe and Western America, though its real home is in the southern oceans. Albatrosses commonly breed in large colonies. In the island of Laysan, in the Pacific Ocean, thousands of these birds can be seen, each brooding its single white egg. The nestling is covered with white down of extraordinary length, and it is remarkable for the great length of 
time it remains in the nest. The wings of the Albatross spread as much as ten feet, but though so long, they are very narrow, not more than a foot in width at the widest point. In rising from the water it has some difficulty in getting under way, but once on the wing the flight is unexcelled by that of any other bird. These birds often follow ships at sea for days at a time, and there is a superstition among sailors that it is bad luck to shoot or otherwise injure one of them. This sentiment has been made use of by Coleridge in his "Rime of the Ancient Mariner," in which he tells of the sufferings of a ship's crew after the shooting of one of these birds. See Plate 38, Fig. 221.

Albatrosses are very plentiful in the islands of the Pacific Ocean. A writer who has studied them there says they behave very strangely at the mating season. Standing face to face, they begin nodding and bowing vigorously, and then rub their bills together with a whistling cry. After this they begin shaking their heads and snapping their bills with marvellous rapidity, occasionally lifting one wing, straightening themselves out, and blowing out their breasts. Then they put their bill under their wings or toss it in the air, with a groaning scream, and walk round each other, often for fifteen minutes at a time.

The largest and perhaps best known species is the Wandering Albatross. Its plumage is, in general, white, with some black markings, the feet are pinkish, and the bill is yellow. Another well-defined, much smaller species is the Sooty Albatross, so called from its very dark colour. 
While the food of these birds consists chiefly of liv- ing fish, they also act as scavengers on the ocean.

The Manx Shearwater may be regarded as a typical Petrel. This bird breeds in considerable numbers in the Hebrides, though in some of the islands, curiously enough, it has been ousted by the Puffins, a much smaller but very pugnacious bird. About a hundred years ago the Puffins began to increase rapidly, and drove the Shearwaters from the holes which they occupied in the cliffs, so that now comparatively few remain. The young of this bird remain in the nest-burrow until long after they are fully fledged, becoming, in consequence, enormously fat. See Plate 37, Fig. 215.

Leach's Fork-tailed Petrel is met with quite commonly in both American and European waters, having quite an extensive range in Atlantic and Pacific waters. See Plate 37, Fig. 214.

Perhaps the most interesting of all the Petrels is the little Stormy Petrel, known to sailors as "Mother Carey's Chicken," whose appearance is supposed to indicate a coming storm. Against the vast bulk of the ocean it looks extremely small, seen through the driving spray. Although, like the other members of this family, the Stormy Petrel spends most of its time on the ocean, it nests in holes in the ground. Many of them are to be seen during the breeding season at the mouth of the St. Lawrence River on the Percé Rocks.

As a rule, Petrels are dark-coloured above, and lighter below; but one species, the beautiful Snow Petrel of the icy regions of the Antartic, is all pure 


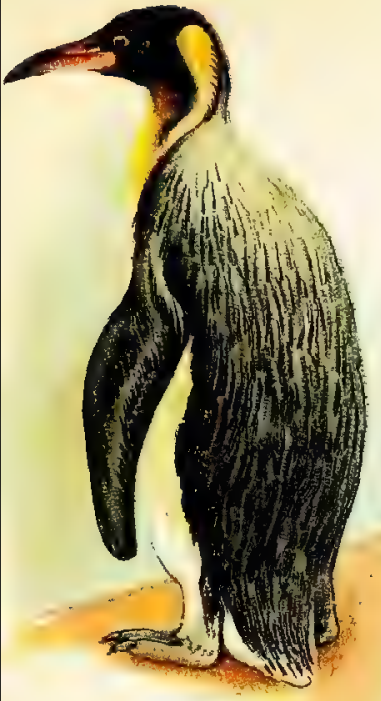

234. Great King Penguin (Aptenodytes patagunica).
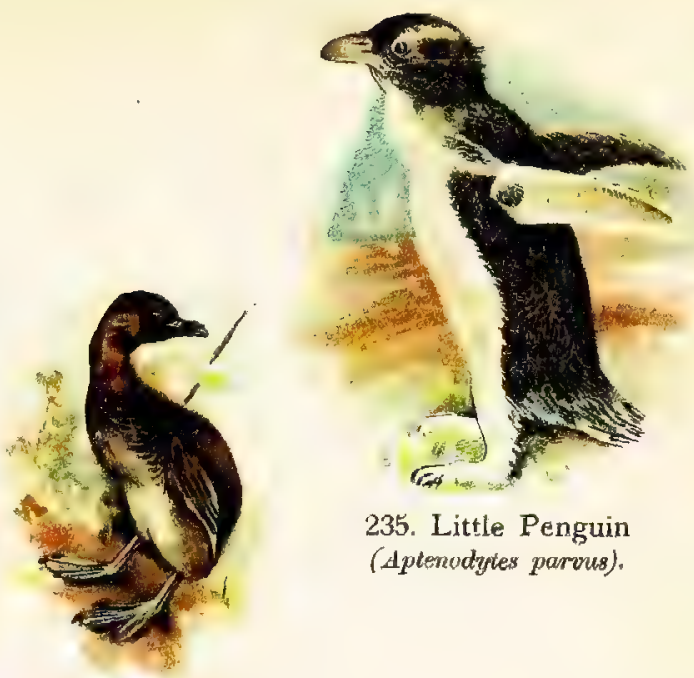

235. Little Penguin (Aptenodyies parous).
237. Little Grebe

(Colymbus fuviatilis).
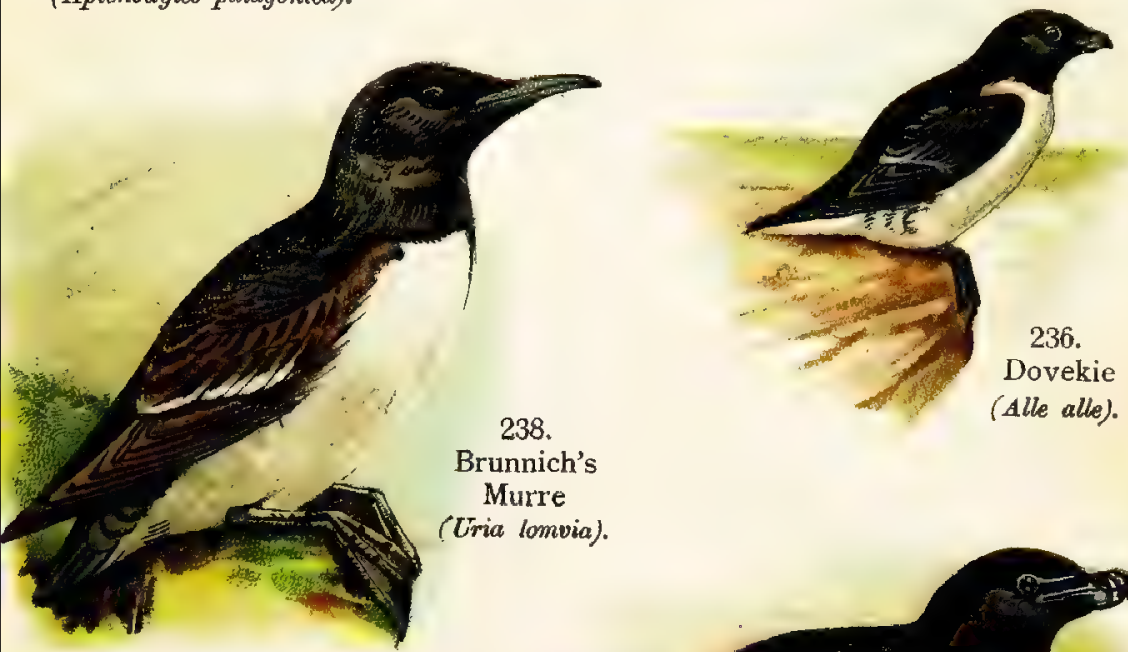

Brunnich's

Murre

(Lria lomvia).

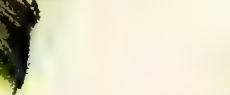

239. Razor-billed Auk (Alca torda). 

white; and the Great, or Giant Petrel, when it wanders to the far south, also becomes white.

Petrels were supposed by the older naturalists to be nearly related to the Seagulls, which they closely resemble. But the resemblance may be purely superficial, and due to their similar modes of life.

\section{Penguins}

The Penguins are perhaps the most remarkable of all the carinate birds. No other family has become so profoundly modified and adapted for an aquatic life. Though the bird-like shape is retained, the wings have become transformed into paddles, resembling those of whales, and with these paddles Penguins propel themselves through the water after the fashion of a bird flying through the air. When on land Penguins stand almost perfectly erect, with their wings, or flippers, hanging at their sides, in an attitude unlike that taken by any other bird. When seen in this position and from a distance they look not unlike a band of small men, as they waddle along in single file across the ice. In captivity they seldom live long, but are very intelligent, soon learning to recognise their keepers. 'Their food consists exclusively of fish.

These birds are confined absolutely to the southern hemisphere. In size they vary enormously, the largest species being represented by the King Penguin and the Emperor Penguin, which stand about four feet high; while the smallest is the Little Penguin of New Zealand, no larger than a small Duck. See Plate 40, Fig. 235. 
The King and Emperor Penguins are found only in the inhospitable regions of the Antarctic, a land of perpetual ice and snow. They lay but one egg during the year, and this is most carefully guarded. To protect it from the cold, it is placed as soon as laid, upon the back of the feet and covered by the feathers of the lower part of the abdomen. It is brooded by each parent in turn until hatched, when the young bird is cared for in the same way. The young of these two species are very unlike, the young King Penguin being covered with long, hair-like, tawny-coloured down, while the young Emperor is clad in down that is pure white except for black markings on the head. Certain other species of Penguins build nests either on the open ground or under ledges of rock.

Owing to the complete transformation of their wings into flippers, Penguins are quite unable to fly. They are also unable to breathe through their nostrils, these having become completely closed.

Penguins have no very near relatives among living birds; but they stand nearest to the Diving-birds, which, however, they far surpass, both in their ability to walk when on land, and in their wonderful swimming and diving powers. Fossilised forms of Penguins have béen found in N"ew Zealand, one exceeding in height an average man. See Plate 40, Fig. 234. 


\title{
CHAPTER IV
}

\section{The Totipalmate Birds: Herons, Storks, and}

\author{
FLAMingoes
}

\section{ORDERS-STEGANOPODES, ARDEÆ, CI- CONI A, AND PHENICOPTERI}

7 HE birds which form the subject of this chapter comprise a number of distinct groups which, at first sight, seem to have little in common, for, in the first place, while some are web-footed, others are not. As a matter of fact, however, a study of their anatomy shows that they are all closely related.

\section{The Totipalmate Birds}

The birds which are known as the Totipalmate, or Steganopodous, birds were grouped together by the

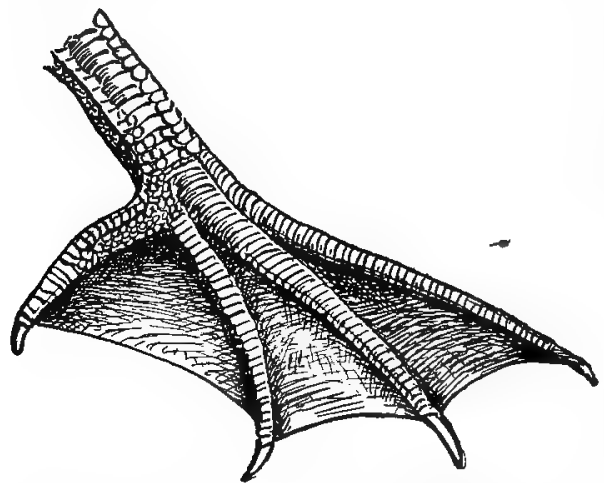

Fig. it.-Foot of a Cormorant, to SHOW THE TOTIPALMATE CONDITIONALL FOUR TOES UNITED IN A COMMON WEB. older naturalists because they diff e r ed from all other web - footed birds in that all the four toes are united by a-continuous web, whereas in the other webfooted birds the $h$ in d - t o e, when present, is free. The labours of 
later workers have shown that this association was justified.

The best known of these Totipalmate birds are the Cormorants and Gannets.

The Common Cormorant is a bird which enjoys a very wide distribution over the earth's surface, being common in Europe and Asia, and in America along the Atlantic and Pacific coasts. It is a rather large bird, being about three feet long, of a wonderful dark-green colour, and having emerald-green eyes. The neck is long, the bill heavy and furnished with a very sharp recurved hook, useful in seizing fish. The feathers of this bird are velvety and scale-like in appearance, very thick, and they lie close to the body. Although such an expert swimmer and diver, the Cormorant is also strong in flight, once well on the wing, and in Florida numbers of them are seen soaring high in the air, or flying in a straight line like that taken by Wild Ducks. The feathers of the Cormorant, like those of the Snake-bird (hereafter described), become saturated with water, so that the bird is obliged to dry them by sitting in the sun on exposed branches of trees. During the breeding season, the sides of the neck are marked by long hair-like white feathers, while a similar white patch occurs on the thighs. The head, with its remarkable eyes, is quite reptile-like in character, as are also the actions of the bird. On the Pacific coast and adjacent islands they congregate in thousands, and may be seen, together with Murres and Guillemots, seated on the rocks. In captivity they are very quarrelsome, squabbling and fighting almost continually, and unless kept in a large enclosure are 
apt to kill each other, the sharp and heavy beak dealing terrible blows.

The nestlings are ugly little creatures, covered with short black down, which gives place to a brown plumage. The eyes of the young are brown, also. Not until they are fully grown is the dark-green dress assumed. See Plate 37, Fig. 218.

The wonderful skill displayed by the Cormorant in its pursuit of fish is turned to good account by the Chinese and Japanese, who domesticate these birds and train them to catch fish. By the ingenious device of placing a ring around the neck, their masters prevent the birds from swallowing their captures, and compel them to bring each fish as it is caught to the raft from which the fishing is carried on.

There are many species of Cormorants, the smallest being but twenty-two inches long. This species is found in Central and South Europe, North Africa, and Central and Southwest Asia. The largest species, known as Harris's Cormorant, is nearly extinct, and is found only in one of the Galapagos Islands, off the coast of South America. It is much larger than the common Cormorant, but has quite lost the power of flight, and so does not have the keel of the breast-bone. Very nearly related to the Cormorant is a remarkable bird known as the Darter, Snake-bird, or Water Turkey, differing chiefly in the great length and slenderness of the neck, from which character it derives its common name. The beak of the Snake-bird is quite unlike that of the Cormorant, being very sharply pointed, while its edges are armed with fine needle-like spines. When fishing, the Darter spears its victim, 
and brings it wriggling to the surface, when it is tossed up and swallowed. See Plate 38, Fig. 222.

The subject illustrated here is a native of tropica? and sub-tropical America, ranging northwards to West Mexico and South Carolina; but different species are met with in other parts of the world. Like the Cormorants, the Darters, in summer, have the neck adorned with long, white, hair-like feathers, known as filo-plumes. They are further remarkable for the fact that the tail-feathers are curiously corrugated. Though occurring on the sea-coasts, the Darter is more strictly a river bird.

One of the best known species of Snake-bird nests in the swamps and lagoons of Florida, and these birds may often be seen sitting on branches of trees in the bright sunlight, drying themselves after the manner of the Cormorants. While in this position, although the body and wings remain stationary, the head is continually turning round on the snake-like neck. Darters are extremely wary and difficult to approach. They are strong and graceful in flight, soaring high above their nests, much like the Eagle. The male bird is a rich dark bottle-green colour, with very soft and shining feathers. The upper feathers on the wing and back are covered with a curious chalk-like substance, forming a pattern which looks not unlike lace overlying the dark green. This substance is only on the surface of the feathers, however, and can easily be rubbed off. During the breeding season, the eyelids and the bare skin around the base of the beak become very brilliant in colour, an emerald-green, with outer edges shading into deep cerulean blue, while the eye 


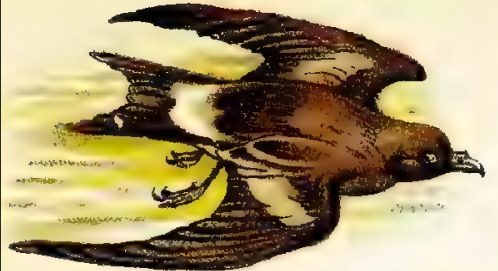

214. Leach's

Petrel

(Oceanodrona

lewcurhoa).
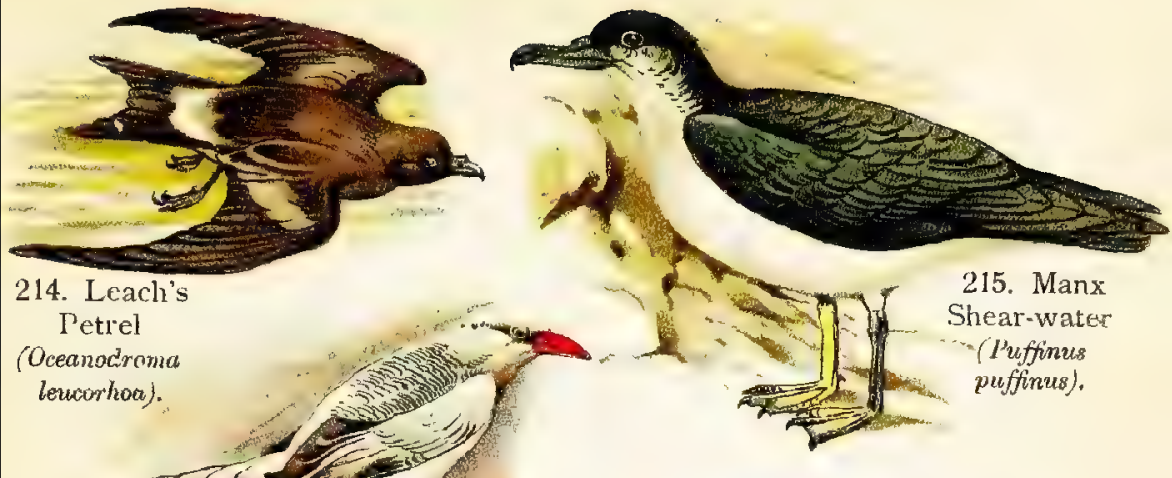

215. Manx

Shear-water

(Puftinus

puffinus).
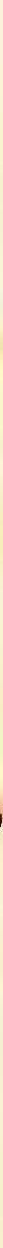

218. Comorant

(Phalacracorax carbo).

217. Gannet

(Sula bosana).

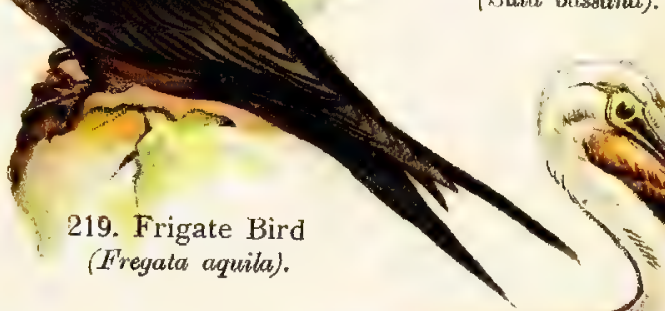

219. Frigate Bird

Fregata aquila) 

itself is bright red. The mouth and inside of the throat are deep purple. The female is much more soberly coloured, and is a lightish-brown over most of the body.

When shot at on the wing, the Darter drops immediately to the water and dives beneath it, holding to the weeds at the bottom with its bill. If wounded, it will continue to hold on until drowned, and cannot be recovered. Owing to the extreme toughness and solidity of its muscles, the Darter is very difficult to kill. If startled when swimming on the surface of the water, it quickly dives beneath, and swims with only the tip of the head and bill projecting.

The eggs of both Darters and Cormorants are cova ered with a thin layer of chalk, which may be scraped away, revealing a shell of a very delicate greenish-blue colour.

The Common Gannet, also known as the Solan Goose, is found along the Atlantic coasts of America and Europe. During the breeding season they congregate in large numbers on rocky ledges, and, although strong flyers, they are never found far from land. Though closely related to the Cormorants and Darters, they differ from them, not only in shape and colouration, but in their method of fishing. Their prey is captured, not by pursuit under water, but by pouncing upon it from a great height in the air.

The adult bird in both sexes is pure white, except for the primaries, which are black, and a light buff tinge over the head and neck. The young birds are a blackish ash colour, flecked with white, but, year by 
year, at each successive moult, they grow paler, until, at the sixth year, they assume the fully adult dress.

Large numbers of Gannets breed on the rocks at the mouth of the St. Lawrence River, in company with many other forms of sea-birds. As many as nine species are known, and all are remarkable for the fact that under the skin is a wonderful system of air-cells, which serve to break the force of the impact with the water when the birds dive for their food. Like the Cormorants, Darters, and Penguins, the Gannets have no external nostrils, but breathe only through the mouth. See Plate 37, Fig. $21 \%$.

\section{Pelicans, Tropic Birds, and Frigate Birds}

These birds are very remarkable types, nearly related to one another, and to the Cormorants and Gannets.

Pelicans are found in all the continents of the world. The European White Pelican, which is figured, is a native of Southern Europe and Africa, ranging eastward into Northern India. The American White Pelican closely resembles it, and breeds extensively in the northwestern parts of the United States, notably on lakes in California and Oregon, and on islands in Lake Utah, Utah. These are the largest of the Pelicans, having a wing-spread of eight and a half feet. A curious thing about these birds is that although the feathers are pure white, after immersion in the water they have a delicate pink hue, which slowly fades as they become dry. All Pelicans are provided with a pouch of skin which hangs down from 
the lower mandible and is capable of being enormously distended. When not in use, this pouch is drawn up so as to be hardly noticeable. During the breeding season the upper part of the bill of the male is ornamented by a horny knob, which is afterwards shed. See Plate 37, Fig. 220.

The Brown Pelican of Florida and the Pacific coasts is not more than half the size of the White Pelican, and has somewhat different feeding habits. When in search of food, they fly slowly along, in single file, twenty or thirty feet apart and fifteen or twenty feet above the water, alternately flapping and sailing for short distances. Catching sight of a fish, a Pelican suddenly drops, after the manner of the Gannet, opens the mouth to the widest extent, the pouch automatically rounding into a scoop at the same time, and seizes its prey. Pelicans not only swim with great facility, but on the wing are almost unrivalled.

One of the principal breeding places of the Brown Pelican is Pelican Island, in the Indian River. For years these birds were much hunted and were in danger of extinction, but owing to the efforts of the Audubon Society they are now strictly protected and a permanent warden is stationed on the adjoining mainland to see that the laws are enforced. They are consequently rapidly increasing in numbers, as many as six or eight thousand birds nesting on that island alone. It is low and boggy, scarcely rising above the surface of the water, and at times is practically inundated. The few thinly scattered mangrove bushes are occupied to the fullest capacity by the nesting Pelicans, and others build upon the 
ground. The nest consists of a few twigs and branches of the mangrove loosely woven together, and is rather an insecure affair. When hatched, the young are naked, and purplish-black in colour, with eyes tightly closed. 'They gradually become covered with a soft white down, which is succeeded by soft greyish feathers, and the adult plumage is not attained until the bird is several years old. At maturity, the top of the head is white, with a yellowish tinge, the neck sealbrown and having much the character of a piece of old sealskin. The pouch is purplish-black, and the general colour of the bird is a mixture of grey, white and brown. The general effect, however, is far from brown, but is rather a purplish-grey.

When at rest, the head of the bird is bent down, with the bill pressed closely against the breast. This attitude seems to be simply a matter of balance, as the legs of the Brown Pelican are so far back on the body that when the bill is stretched forward horizontally it overbalances the bird.

These Pelicans are not at all shy, and may be approached closely while on their nests, although at such times they strike at the intruder with their bill. Before the young are able to fly, they jump down from their nests and congregate in large numbers on the shore. When alarmed, they take to the water.

It is interesting to see the old birds coming home to their young after a day's fishing. On approaching the nest, the young ones awake from the seeming lethargy in which they have been during the day, and stretching their necks upward, thrust their heads into the pouches of the parents, which are opened widely 

to receive them. The adults travel many miles a day in search of food, leaving the nests early in the morning and sometimes not returning until dusk. Occasionally an Eagle will attack the young birds during the parents' absence, but as a rule they are not molested.

The Brown Pelican does not at any season of the year develop the brilliant colours of beak and pouch displayed by its white relative, nor does the horny excrescence on the bill of the latter ever make its appearance.

The Frigate, or Man-of-war Bird, is met with throughout the tropical regions of the world, and has even strayed so far north as Nova Scotia. It is a remarkable bird in many ways. Spending the greater part of its life on the wing, it has but little use for legs, and as a consequence has acquired the distinction of having the smallest feet, for its size, of any living bird. Feeding upon squids, small crabs, flying-fish, and young turtles when they come in their way, Frigate Birds nevertheless derive no small part of their food by robbing others. Their victims are chiefly Terns and Gannets, which, returning home with full crops, are chased and made to disgorge their captures. Before the coveted morsel has reached the sea again, it is caught up by these unscrupulous highwaymen and promptly swallowed. See Plate 37, Fig. 219.

During the nesting-season the males develop beneath the beak a great pouch of a brilliant red colour. This can be inflated, at the will of the bird, until it rivals the rest of the body in size. "A dozen or more of these birds sitting in a tree," says Dr. Andrews, 
of the British Museum, "with outstretched, drooping wings, and this great scarlet bladder under their heads, is a most remarkable sight. When a hen bird," he continues, "approaches the tree, the males utter a peculiar cry, a sort of 'wow-wow-wow-wow' and clatter their beaks like castanets, at the same time shaking the wings." The Frigate Bird is probably the strongest flyer of any bird in the world. It is able to ride out the fiercest storms, and has been seen during heavy gales soaring quietly in the air, without any flapping of the wings. In shape it is peculiar, having extremely long, pointed wings, a long, forked tail, a strong, hooked bill, with a pouch like the Pelican. The East Indians make use of this bird as a Carrier Pigeon.

The Tropic Bird, or Boatswain Bird, is a native of the tropical portions of the Pacific and Atlantic Oceans, and measures about 40 inches in length; but this includes the long tail, which has a length of about 26 inches. See Plate 37, Fig. 216.

Altogether six species are known, of which three are American. Tropic Birds are true denizens of the ocean, often being met with many hundreds of miles from the land. Their flight is rapid and sweeping. Like the Gannet, they procure their prey by diving, often from an immense height, in the air. On land, as might be expected, they are greatly at a disadvantage, and walk with a shuffling gait. Though the majority of the species are white, with black pencillings, one is remarkable for the exquisite orange colour of its plumage. 


\section{EUROPEAN HERON-WARD'S HERON 33}

\section{The Heron Tribe}

While the birds which we have just described are all remarkable for the shortness of their legs, the types now to be considered are distinguished by the great length of their legs. This difference is due to the fact that the Herons and their near relations catch their prey by wading in shallow water, whereas the birds just described either procure their prey under water, or capture it by plunging from a height.

The Common European Heron is still found on the streams and mud flats of secluded neighbourhoods; but it is a very wary bird, and must be approached with great caution. In the days of feudal England it was strictly protected, on account of the sport it afforded in falconry, but the wonderful sight of a "heronry," as a nesting-colony of these birds is called, is becoming more and more rare. Their food consists largely of small mammals and fish.

The nests of these birds, constructed of sticks, are usually placed in the tops of trees, but they will also build upon the ground. See Plate 33, Fig. 192.

The Common European Heron enjoys a wide range, occurring over the greater part of Europe and Asia, and in most parts of Africa and Madagascar. It is also found in Australia. This bird's place is taken in America by the Great Blue Heron, one of the largest of the species. It has a very extensive range, being found throughout most of the eastern and southern States, and a particularly large variety, called Ward's Heron, occurs in Florida. Standing about four feet in height, when fully adult, this is a 
magnificent and imposing bird in appearance. When in full plumage, from the back of the head there run two long black plumes, and these, together with shorter ones, form a crest which the bird raises when excited or alarmed. The bill is long, and sharply pointed, and with it the Heron can deal a terrible thrust. It is semi-nocturnal in habits, and, like all other Herons, procures its food by wading in shallow water and quickly darting out the long neck, seizing its prey with the sharp bill. It is shy and wary, and very difficult to approach. When disturbed, it rises heavily in the air, flapping its broad wings slowly, and uttering harsh guttural croaks. The Great Blue Heron chooses widely varying sites for its nest, but in Florida usually builds in the top of tall pine trees, some distance from the water.

The Great White Heron, rivalling, or even exceeding in size the Great Blue, is now comparatively rare in its former haunts. The plumage of this bird is entirely white. The feathers of all the Herons are loose on the body, and powder-down feathers are always present. It is thought by some naturalists that the powder from them makes the feathers of the bird waterproof.

The Little Green Heron is the smallest of the American species, as well as the commonest. It is popularly called the Shitepoke. The general effect of colouration is not green, as one would think from the name, the neck and head being a delicate brownish hue, while the rest of the plumage is exquisitely coloured in delicate shades of grey and green. The Little Green Heron is more solitary in habits than 
most other members of this family, though it sometimes builds in heronries. The nests are roughly made, usually placed in branches of trees, or in bushes, and the eggs vary from three to six in number. The young are covered with hair-like feathers, and are helpless for some time.

The Louisiana Heron is a common form in Florida, and is very beautiful in plumage, being a delicate bluish-grey on the back and yellowish-brown on the breast.

There are two species of Night Herons in America, the Black-crowned and the Yellow-crowned. These birds are entirely nocturnal in habits, and are commonly known as "Quawks," from the cry they utter when sailing through the air. When fully adult, the male Black-crowned Heron is very beautiful in colour. The head and back are greenish-black, the wings and tail greyish-black, and two long white plumes depend from the back of the head, except just after the breeding season, when they are shed. The eye is very large, and of a deep blood-red. Large colonies of these birds nest in the swamps of Florida, sitting silent by day, brooding in quiet spots among the trees, but at night they rouse and fly forth, uttering their peculiar cry, to their feeding grounds in neighbouring streams.

Among the Heron tribe are certain species which possess in a remarkable degree the "fatal gift of beauty." These are known as Egrets, chief among. them being the Great White Egret, found in many parts of Europe and Asia, and the Snowy Egret and Little Egret of America. The Snowy Egret is pure 
white in colour of plumage, has a golden yellow eye and yellow bill, black legs, and yellow feet. During the breeding season, both males and females develop exceedingly fine recurved plumes growing from the back and falling over the wings. These are known to commerce as "aigrettes," and in consequence of their popularity among ladies of fashion this beautiful bird is rapidly becoming extinct. See Plate 33, Fig. 193.

The American Egret is also white, but has black legs and feet. Its plumes grow from the back, like those of the Snowy Egret, but are straight instead of recurved. In habits the Herons are a very homogeneous family. All secure their prey by stealth, or stalking, standing quietly in the water until a fish approaches, when they quickly dart out the long neck and transfix it with the powerful beak. All are strong flyers, though their feathers are rather loosely set on the body. The vertebræ of the neck are joined so as to form the letter $\mathbf{S}$ in the resting attitude of the bird, the spring giving added power to the forward stroke of the neck when thrust suddenly out. These birds are determined fighters, and when wounded must be approached with care in order to avoid the rapid thrusts of the sharp bill, which can inflict terrible injury. They seem to strike preferably at the eyes, and many a dog has been blinded by a Heron that had been partly disabled by a shot from his master's gun.

In the feudal days of England, hunting Herons by means of the Peregrine Falcon was a farourite sport with lords and ladies. A party would set forth 
on horseback, with Falcons attached to the wrists of attendants, and when a Heron was sighted flying high in the air the Falcons were released. The Heron would double and twist in every direction, in order to avoid the terrible claws of the pursuing Falcon, and often gave a good account of itself, but was usually no match for its more active adversary.

From the Herons we pass to the Bitterns. This bird is remarkable for the wonderful way in wlich its plumage harmonises with its surroundings, and, as if aware of this, the Bittern seeks safety in moments of danger, not by flight, but by sitting close, with upstretched neck and beak, among the reeds. When in this attitude, with the bill pointing skywards, the eyes, curiously enough, may be directed forward over its base and toward the observer. The American Bittern is similar to the Common European Bittern. Like the Herons, it is a bird that delights in desolate places, in secluded swamps and marshes, from which the curious booming noise it makes is heard at frequent intervals during the evening hours. See Plate 33, Fig. 194.

An unusual feature about the Bittern is the wide fringe of long feathers which runs along the throat, and which, when extended, gives the neck a very wide appearance. When depressed, these feathers meet at the back of the neck, which is clothed only in short down.

In both Herons and Bitterns the middle claw bears along its inner edge a comb-like fringe, while on the breast and thighs are patches of the remarkable feathers known as powder-down. These feathers break up 
in the form of an exceedingly fine powder, but it is not known what purpose this powder serves, although there are many theories in regard to it.

\section{Storks, Spoonbills, and IbIses}

Though very like the Herons in habits and general shape, the Storks differ from them in many anatomical characters. There are a number of species, perhaps the best known being the White Stork of Europe. In colour it is rather striking, the plumage being white over the body, the wings tipped with black, the bill and legs a bright red. Although so large a bird, standing four feet in height, this Stork is a powerful flyer, making yearly trips to Africa across the Mediterranean during the migrating season. Unlike the Herons, which have long, spreading toes, enabling them to wade in shallow streams, the Stork has comparatively short toes, although it frequents marshy places, seeking the snakes, frogs and lizards which form its principal food. See Plate 33, Fig. 191.

For generations the Stork has been held in great esteem by the natives of Holland and Germany, where it has been rigidly protected, and in consequence has become very tame, building nests upon the tops of chimneys even in thickly populated towns.

The Adjutant Storks, which occur in India and Africa, are of enormous size, standing five or six feet in height. Hanging down in front of the neck is a bag which can be filled and emptied of air at the will of the bird. These Storks are sometimes called Marabous, and furnish the ornamental feathers known to 
commerce as marabou plumes. The African Adjutant Stork has a heavy, sharply pointed bill, and the top of the head and neck has a curious bald and shrivelled appearance. From this scaly skin projects a few sparse feathers resembling hairs, and as the bird stands with its head sunken between its shoulders in a dejected attitude, it looks not unlike some weak and tottering old man. See Plate 34, Fig. 195.

This Stork is extremely voracious, and can swallow very large objects at a gulp. It is a scavenger, and in some places is protected by law. Although so ungainly when at rest, this bird is very majestic in flight, the wings being long and powerful.

In Central Africa is found a species known as the Whale-headed Stork, from the enormous development of its bill.

The Jabiru is a Stork-like bird found in South and Central America. The bill is long and heavy and slightly recurved at the tip. The plumage is almost entirely white; the feet, bill and bare skin on the neck are black.

The European Spoonbill is a bird which a few centuries ago bred commonly in marshy districts throughout Europe, but is now, largely owing to drainage, only an accidental visitor. The bird derives its name from the curious spoon-like shape of the bill. See Plate 33, Fig. 190.

The Roseate Spoonbill of America, closely allied to the European species, is remarkable for the exquisite reddish tint of its plumage, which is particularly bright on the under portions of the body and wings. The Spoonbill uses its bill very dexterously 
in securing its food as it wades about in the water, scooping up the fish and frogs that come in its way.

The Ibises, though they bear a superficial resemblance to the Curlews, really belong to the Stork tribe, and are most nearly related to the Spoonbills. These birds, like the preceding, are limited to the warmer regions of the earth. The Sacred Ibis of Egypt was an object of worship, and after death was embalmed by the ancient Egyptians. The veneration in which it was held may be seen from the various representations of it upon the obelisks and other remains of a former civilisation. In form the Sacred Ibis is not prepossessing. The long, downward curving bill, bare head and neck are black in colour, the skin of the legs is also blackish. These birds are extremely inquisitive and bold, but are rather difficult to approach on account of their remarkably keen sight. The long bill is used as a probe, and the bird is continually inserting it into holes and crevices, either in search of food or simply to satisfy its curiosity. See Plate 34, Fig. 196.

The Scarlet Ibis of our Southern States is the most brilliantly coloured species known, and is probably the brightest in hue of all living birds. For some reason, however, the bird soon loses its glorious colour in confinement, though it has been recently found that by the use of certain kinds of food the colour can be to some extent retained. In form this species is more delicate and smaller than the Sacred Ibis. It is being rapidly exterminated by plume-hunters.

The Wood Ibis, which is really a Stork, is a larger bird than those already described, but is coloured 
somewhat like the Sacred Ibis, the plumage being white, the wings and tail tipped with black, the bare skin of the head and feet dark in colour. These birds nest in thick swamps in the interior of Florida, and may be seen standing idly about in the blazing sun, extending their wings as if enjoying the great heat, or possibly to cool their bodies.

The Glossy Ibis is another American form that is yearly becoming more rare. It is dark brown, almost black, in colour, over which runs a brilliant greenish iridescence.

The White Ibis is the commonest species found in this country. The plumage is pure white, except for the tips of the primaries, which are dark green, iridescent, and in striking contrast to the rest of the plumage. The naked skin of the face is orange-red. These birds are seen in Florida flying in long lines to their feeding-grounds in the swamps, and adding much interest to what would otherwise be a most monotonous landscape.

\section{Flamingoes}

As to the exact relationships of the Flamingoes there are many opinions among naturalists. Some authorities regard them as long-legged Geese, others as Storks with goose-like beaks; and probably the latter view is nearer the truth. The beak of the Flamingo is unique in shape, being bent downwards in the middle; but it is provided with ridges, or "gutters," like those found in Ducks and Geese. Hence the supposed relationship to these birds. Their common name is derived from their flaming colour. 
The European Flamingo is still quite common about the salt-water lagoons of France and Spain, and is occasionally found in Great Britain. See Plate 33, Fig. 189.

Of the seven or eight species known, four are American. One of the principal species breeds in Florida and in certain of the Bahama Islands, which are little more than low coral reefs covered with scant vegetation and mud-flats. Here they congregate in vast numbers, scraping up the mud to make their wonderful nests, from eighteen inches to two feet in height. The young are unlike the parent birds, having short legs, and looking not unlike young geese. The beak, too, is almost straight and does not assume the recurved form until the bird is fully adult. The use of the peculiar shaped bill is seen when the Flamingo is feeding. Owing to its extremely long legs, the head is turned upside down as the creature dabbles about in the water in search of its food, the lower part of the beak becoming uppermost.

Mr. Chapman, in his "Camps and Cruises of an Ornithologist," says: "Flamingoes in flight resemble no other bird known to me. With legs and neck fully outstretched, and the comparatively small wings set half way between bill and toes, they look as if they might fly backward or forward with equal ease. They progress more rapidly than a Heron, and, when hurried, fly with a singular serpentine motion of the neck and body, as if crawling in the air."

The plumage is dense, like that of a Duck, and lies close to the body. The primaries and secondaries of the wings are black, and form a striking contrast to 
the rest of the plumage. For some unknown reason the brilliant colour of the Flamingo, like that of the Ibis, fades in captivity, possibly owing to the difficulty of obtaining the proper food. When at rest, this bird usually stands upon one leg, the other being drawn up against the body, with the long foot and toes projecting at right angles to the supporting limb. The voice of the Flamingo is a harsh croak, and when on their feeding-grounds these birds are extremely noisy, their combined voices making an uproar that may be heard for a great distance. 


\section{CHAPTER V}

\section{The Ducks, Geese and Swans}

\section{ORDER-ANSERES}

THE Ducks, Geese and Swans form a welldefined order of birds, which appear to be related on the one hand to the Totipalmate birds and Storks, and on the other to the birds of prey. All are aquatic in their habits, short-legged and web-footed, and all have very large, thick, fleshy tongues.

Unlike the Totipalmate birds and Storks, their nestlings leave the egg in a very forward state, so that they can run and swim almost immediately after hatching.

The Saw-billed or Fishing Ducks are remarkable for the fact that the edges of the beak are armed with sharp, conical, horny, tooth-like spines, admirably adapted for the capture of the slippery fish on which these birds live.

Ducks are distinguished, as a rule, by elaborately coloured plumage. Some species are very brilliantly marked, but many of them are principally black and white, with spots and stripes arranged in various delicate patterns over the body, giving a most charming effect.

All the members of this family are strong and rapid 
flyers, rising from the water instantly and flying straight ahead at very great speed. When migrating, they rise to a great height above the earth, and travel for many hours without resting. The wing-beat is so fast as to be almost invisible, and it is difficult to imagine how such speed can be kept up for so long a time without the birds becoming exhausted. They are gregarious, flying in large flocks, and are usually very noisy, quacking and calling almost continuously. Many species are common to both the Old and the New World, and seem to travel with ease between the northern parts of the two continents, such forms as the Scoters, Pintails, Widgeons, in particular, being found in both countries. In fact, Ducks are spread over almost the entire surface of the earth, some species living in the far North, while others inhabit tropical and subtropical regions. Some are confined to fresh water, others seem to prefer the shores of the ocean. The latter may be distinguished by the lobe on the hind toe. See Plate 35, Figs. 204, 205.

One species, known as the Labrador Duck, of which only a few skins are preserved in museums, has become exterminated within recent times. In the early part of this century it was common in the Arctic regions, but for some unexplained reason these birds suddenly disappeared, so far as is known not one existing at the present time.

The Goosander, found in the northern parts of both continents, and the Smew, are typical examples of the Saw-bill Duck. In them the bill is rounded, instead of flattened, as in most other species, and is provided with tooth-like spines. It also has a hook at the tip. 
The feet and bill of the Goosander are a bright red, the head is dark green, the upper part of the body black and white, and the lower part white washed with pink. The Hooded Merganser, a smaller bird, is also black and white in general colouring, and has a beautiful crest, from which it takes its name. See Plate 36, Fig. $20 \%$.

The Smew is a small Fishing Duck found only in the more northerly parts of the Old World. The colouring of the adult male is white, varied with black, the head crested and dark green. The general colour of the female is reddish-brown. See Plate 36, Fig. 210.

The Velvet Scoter, or Coot as it is commonly called in America, is a large Sea Duck, frequently met with along the coast in fall and winter. It feeds largely on shellfish, which it obtains by diving. In colour it is a rich velvety black, relieved only by a small white patch on the head and wing and the brilliant orange of beak and legs. Several species of this Duck are found in both America and Europe. See Plate 36; Fig. 212.

The Eider-Duck is one of the best known of the Duck tribe, on account of the fact that its down is so much in demand for domestic purposes. This down is obtained by robbing the nest-material of the breeding birds. It is plucked by the female from her breast to serve as a lining for the nest and a covering for the eggs. In Greenland and in various parts of Iceland and Labrador many people make their living by gathering this beautiful down and selling it. The male plumage is black and white over most of the body, the head greenish, and the female, as is the case 

in so many of the Ducks, is much more soberly cladin brown, with overlying patterns of reddish and greyish colour. Like the preceding species, the EiderDuck is a large form, and has a gibbous, or humped, beak. See Plate 35, Fig. 206.

The Long-tailed Duck is a relative of the Eider, though perhaps not so handsome a bird. The white plumage of the male is relieved by black and washes of dark brown and buff. This bird breeds as far north as the Arctic Ocean, and winters as far south as Virginia. There is considerably more white in the winter colouration than in that of summer In this country the Long-tailed Duck is usually called the Old-Squaw, possibly on account of its noisiness when a large number are gathered together. The long tailfeathers of. this Duck make it easy to distinguish. See Plate 36, Fig. 208.

The Tufted Duck, although well known in Europe, is not found in America. See Plate 36, Fig. 211.

The Golden Eye is common to both countries, the American variety, sometimes also called Garrot, being much larger than the European. This bird is remarkable for the fact that, like a very few of its kind, it lays its eggs in the holes of trees. The colouration is black and white, a distinguishing mark being the round, or crescent-shaped, white spot in front of the eye. See Plate 36, Fig. 213.

Of the Fresh-water Ducks some of the species illustrated are the Mallard, the Teal, the Widgeon, and the Pintail, all of which are conspicuous for their beauty, although, as with the species already de- 
scribed, the brilliant plumage is confined to the males, the females being very dull-coloured.

The Mallard is probably the best known of our American Ducks, and is the bird from which our domestic variety is derived. The male is rather brightly coloured, with a beautiful dark-green, velvety head, and a white ring around the neck, the rest of the body being various shades of brown and grey. The eyes are dark, the legs and feet a bright orange colour. The flesh is excellent, and is much prized for food. The domestic variety is larger than the wild form, and flies with difficulty, owing to the fact that the breast muscles are less developed. See Plate 35, Fig. 203.

The Black Duck seems to be nearly related to the Mallard, but differs from it in that the male and female are almost exactly alike in colour, both being a brownish-black, with a patch of deep iridescent blue on the wings.

Several varieties of Teal are found in this country, the principal forms being the Blue-winged, the Greenwinged, which most nearly resembles the European form, and the Cinnamon. All are most beautiful little Ducks, with very delicate shades of colour in their plumage. See Plate 35, Fig. 202.

Two species of Duck justly celebrated for the delicious flavour of their flesh are the Canvasback and the Redhead, or Pochard. These are near relatives, and are often confused, since the general colour is much the same in both species. The head and part of the neck are reddish-brown, the body a rather warm grey and black, with very fine black lines, or rows of spots, 
on certain feathers. They may at once be distinguished, however, by the differently shaped head and bills. In the Canvasback, the head is pointed at the top, the bill also being sharply pointed and forming a continuous line from the top of the head. The Redhead has the usual rounded head and short, broad bill of most of the family.

Perhaps the most brilliantly coloured of all the Ducks is the Mandarin, a native of China. The male of this species, particularly in the breeding season, has most gorgeously coloured plumage, almost impossible to describe. The bird seems to be cut into sections of colour, some being brown, some blue, some red, white, and so on. The crest is purple and green. These Ducks are rather small, and have the ability to perch well on the branches of trees.

The Wood Duck, or Summer Duck, of America is closely related to the Mandarin, which it somewhat resembles in colouring. It also perches in trees, and, indeed, lays its eggs in the holes of trees, unlike most Ducks, which make their nests on the ground. The female of both the Mandarin and the Wood Duck is dull brown in colour, and almost invisible as she stands by the side of her brilliantly attired mate.

The Aylesburys and the Pekin Ducks are large, white domestic varieties that have practically lost the power of flight. Muscovys, on the other hand, which are descended from the South American Wild Duck, although larger than the two preceding species, have retained the ability to fly. These Ducks are curiously mottled in places with dark green and white, and have 
a knob-like excrescence at the base of the bill. The naked skin around the eye is red.

The Common Scaup is a Duck found in many parts of the world. Three species are known in America, under a great many different names. In some parts of the country it is called the "Raft Duck," from the fact that they swim in large, compact bodies on the surface of the water. When alarmed, they rise in a mass, fly for some distance, and alight in the same compact form. In general colour they resemble the Canvasback and Redhead, except that the head of the male is black instead of red. The flesh is fishy in flavour, and is not particularly esteemed.

In hunting Ducks, different methods are employed, chief among them being the use of decoys-pieces of wood carved and painted to resemble any particular species of Duck. These are placed on the surface of the water, in the neighbourhood of reeds and rushes, the sportsman concealing himself a short distance away under a blind made of bushes. As the wild Ducks fly overhead, they see the decoys, and mistaking them for living birds, drop to the water and attempt to mingle with them. This is the hunter's opportunity to shoot into the flock before it can rise. Owing to their great speed, Ducks are difficult to shoot on the wing, and good judgment is required not to place the charge behind them. They are also able to carry away a considerable amount of shot without falling.

The Sheldrake, or Sheld-duck, is a large, somewhat Goose-like bird found in many parts of Europe, Asia, and Africa, but not represented in America. In 

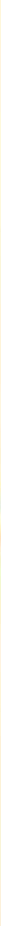

(Nettion crecca).

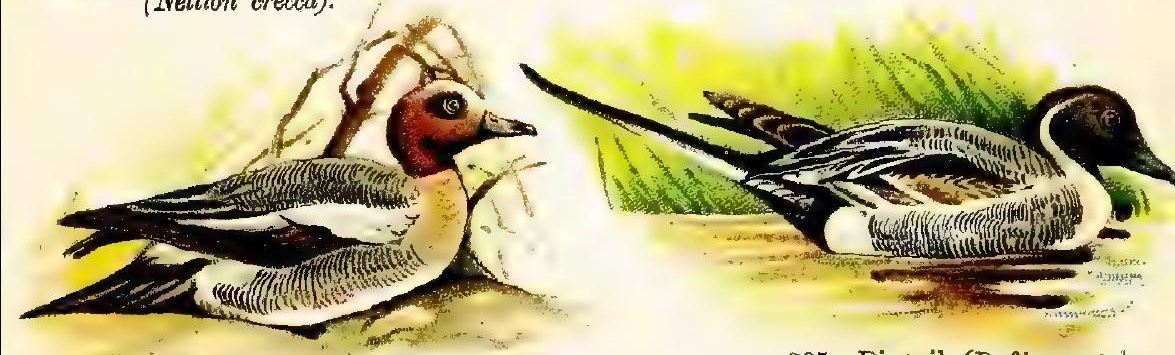

204. European Widgeon (Mareca penelope).

205. Pintail (Dafila acuta).

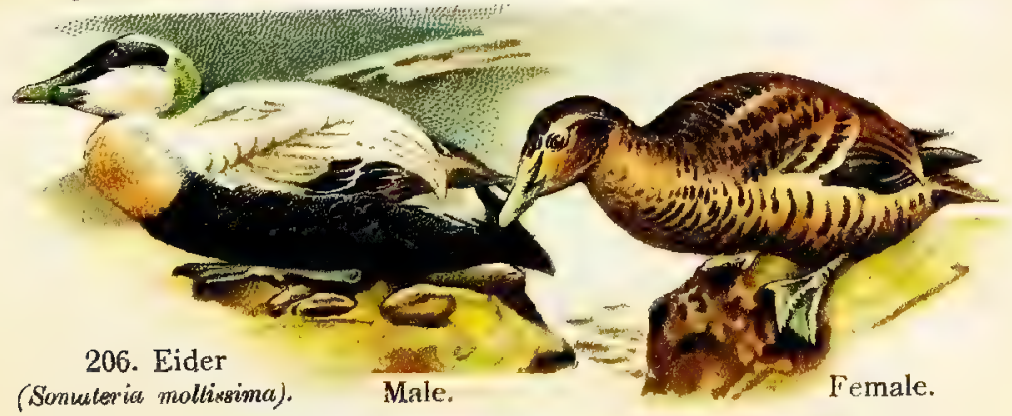



many ways it is remarkable. The sexes are coloured alike, although the female is not quite so vivid in hue as the male. The colours are strongly contrastedpure white relieved by broad bands of bright chestnut, and rich metallic blue-blacks and greens. The beak is a wonderful cherry-colour, the legs and feet are a delicate pink. The Sheldrake is also called "Burrow Duck," from its habit of nesting in burrows underground. These they usually make for themselves, but they will also make use of rabbit-burrows. See Plate 36, Fig. 209.

The Sheldrakes are further remarkable in that they never assume the "eclipse" dress, as it is called. In most other species of Ducks, it will be remembered, the female is a dull brownish hue, and this for a time is assumed by the males, just after the young are hatched. It is at this time that the moult, or annual renewal of the quills, takes place, the Ducks shedding their quills all at once, and not in pairs, as do most other birds, which thus retain the power of flight. Hence they are compelled to seek safety by hiding, which they do very successfully, the sober hues of the female dress harmonising perfectly with the bird's surroundings. But the male Sheldrake, instead of adapting himself in this way to his environment, seeks safety at sea, or crouches among the vegetation near his mate, brooding her eggs in her burrow.

In this country, the Mergansers, or Fishing Ducks, are called Sheldrakes. The Sheldrakes serve as a connecting link between the Ducks and the Geese.

In the true Geese, as in the true Sheldrakes, the sexes are coloured alike-as a rule very soberly, al- 
though in some species the plumage is rather conspicuous. The neck and legs are longer than in Ducks, the bill is thicker, and the hind toe has no lobe. They are also less aquatic than Ducks, spending much time on land and feeding on grass and cereals. The call of the Goose is known as honking; they also give utterance to a hissing sound.

What we may call a typical Goose is represented by the Grey-lag, or common wild Goose of Europe, from which our domestic Goose is supposed to be derived, although other species may be included in the ancestral forms. See Plate 34, Fig. 198.

The Brant Groose breeds in the Arctic regions, and winters southward. It is very generally distributed throughout the northern hemisphere. It is distinguished by white markings on the sides of the neck. The Black Brant, which breeds in Western North America, has a white ring around the neck. See Plate 34, Fig. 199.

A very handsome form is the Snow Goose, in which the plumage is snow-white, relieved by the black quillfeathers of the wings, while the legs and feet are bright red. It breeds in the Arctic regions, and winters from the Chesapeake Bay southward to Cuba. A considerably smaller, but similar, form is called the Lesser Snow Goose. In this the head is sometimes reddish. See Plate 34, Fig. 200.

Perhaps the best known American species is the Canada Goose. It has a white patch on the side of the head, the throat is white, the rest of the neck black. The back and wings are mostly greyish-brown. Like the other wild Geese, this bird breeds in the far North, 
migrating southward in the winter in vast numbers, in a $\mathrm{V}$-shaped wedge, the lead being always taken, it is said, by an old male bird. When one tires he falls back, and another takes his place as leader of the flock.

The White-fronted Goose is represented in both European countries and in America, the American variety being somewhat the larger.

The Chinese were among the first peoples to domesticate Geese, Ducks, and Chickens, and they have bred many singular varieties in the course of the centuries. The so-called Chinese Groose has huge excrescences on top of the bill and curious wattle-like appendages under the throat. Geese have figured for centuries in the history of mankind. They were venerated by the Romans from the fact that they were supposed to have saved the city by their cackling when it was threatened by the Gauls under Brennus.

The domestic Goose is a fierce and aggressive bird, and a blow from its powerful wings has been known to inflict serious injury. The attitude of the Goose when alarmed or angry-lowering its head, hissing, and running after its enemy-is very singular. In Holland and England for many years the Goosegirl has been a well-known figure in literature and in painting. In those countries Geese are taken regularly out to graze in the fields, like sheep or cattle, the birds progressing in a solid body and feeding as they go.

Swans are very large birds, with long sinuous necks, found in most parts of the world except in Africa. On land they are clumsy, owing to the backward position of their legs, waddling along and using their neck 
as a balance; but once in the water, they are differentlooking creatures, gliding smoothly along with the beautiful neck carried in a graceful curve. Although such large birds, when fairly on the wing they have a very powerful flight. Like the Flamingoes, they fly with the neck stretched forward to the fullest extent, with their feet spread out behind them to act as a rudder. From ancient times these birds have been domesticated in Europe and kept as an ornament to streams and lakes.

When nesting, Swans are very savage and courageous, defending their nests to the last extremity. One has been known to break a man's leg by a blow from the powerful wing, and there is an instance of a Swan and a fox having been found dead together, the fox having attacked the young, and killed the parent bird, but losing its own life as well.

When alarmed or excited, the Swan has a curious habit of raising its wings over its back, and the effect of these beautiful feathers falling gracefully backward and reflected in the water is most charming.

Swans are extremely voracious, and when in the same pond with Ducks and Geese will invariably drive them away at feeding-time, if possible.

The best-known species is the European Mute Swan, the one usually seen in public parks and collections. The plumage is white, the bill red, with a curious bulbous place, or knob, at the base. See Plate 35, Fig. 201.

The Australian Black Swan has a neck considerably longer, in proportion, than that of other Swans, and the feathers of the upper part of the body, es- 
pecially over the back, have a curled or ruffled appearance, instead of lying smoothly against the body. It is entirely black except for certain white wing-feathers, and the bill and eyes are red.

Two species of Swan are found in North America, the Trumpeter, so called from its loud, sonorous call, and the Whistling Swan. The former species is now exceedingly rare. Both species breed in the Arctic regions and migrate southward to the Gulf coast. For some reason they have never thriven in confinement. In both forms the plumage is white; the bill and feet are black; and the Whistling Swan is distinguished by a small yellow spot on each side of the bill. The young of all white Swans are greyish or brownish in tone until maturity.

In South America is found the Black-necked Swan, a striking-looking bird with pure white plumage, except for the black neck. The beak in this species is provided with a conspicuous scarlet wattle-a character lacking in the North American Swans, but found in the European forms. 


\section{CHAPTER VI}

Birds of Prey-Secretary-bird, Eagles, Buzzards, Hawks, Krtes, Vultures

and FaLcons

\section{ORDER-ACCIPITRES}

MONG the Birds of Prey the older naturalists included Owls, which they distinguished as Nocturnal, or Night-flying, Birds of Prey. But it is now known that Owls, though in many respects closely resembling the birds to be described in this chapter, are members of a very different group. They are, in short, nearly related to the Nightjars.

The purpose of classification, it must be remembered, is not so much to bring together those birds which are externally similar, as those which are structurally related one to another. Unrelated birds may, and often do, resemble one another, because they lead similar lives, and thus have become slowly changed till they assume a common likeness; while birds, on the other hand, which are really closely related, come to assume very different shapes, because their mode of life is different.

The relationship of birds one to another is to-day determined rather by anatomical structure than by ex- 
ternal form. And it is on these grounds that anatomists have separated the Owls from the Eagle tribe.

The hooked beaks, sharp claws, and upright carriage of the body, which distinguish both the Owls and the Day-flying Birds of Prey, or Accipitres, owe their being to the same causes. That is to say, when the ancestors of these birds began preying on their neighbours, they did it because they were stronger, and had heavier, sharper beaks, and longer, sharper claws than their victims. As time went on, the descendants of these marauders gradually improved these weapons, and this improvement is still taking place.

Birds of Prey are noted for certain striking characteristics, among them their great powers of flight, their fierce and keen eyes, recurved beaks, and sharply curved and pointed claws. In character they differ considerably, some species being bold and aggressive, while others are comparatively shy and retiring. Many of them are very large birds. All are flesheaters, some confining themselves almost entirely to the flesh of animals and birds, while others feed upon small snakes, lizards, and even insects. All, excepting possibly the Caracara, seize their prey with the feet, and not with the bill, driving the pointed talons deep into the flesh and tearing off pieces with their sharp, hooked beaks.

The nests are always flimsy-looking affairs, loosely constructed of sticks placed together. They make most devoted parents, however, both male and female working together to supply the nestlings with food. The young remain in the nests for a considerable time 
before learning to fly, and having voracious appetites, consume enormous quantities of game or carrion during that time.

Birds of Prey are found in all regions of the world, from the tropics to extremely cold countries. In most cases they live in barren, rocky districts, although some species, particularly in South America, are forest-loving, building their nests in the tops of tall trees, from which they are able to see for enormous distances. Some species, such as the Bald Eagle of our own country and the Fish Hawks and the Whitetailed Eagle of Europe, feed almost entirely on fish; others, such as the Golden Eagle, prefer animal diet. Nothing can surpass the energy and dash with which many of the smaller Falcons and Hawks pursue their prey, and an instance has been cited of a Sparrow Hawk impetuously crashing through the glass of a greenhouse in order to get at a bird hanging in a cage inside.

The voice of almost all Birds of Prey is a harsh and rasping scream, and a few species, among them the African Sea Eagles, are extremely noisy, uttering their calls at regular intervals. As a general rule, however, they are silent. They are not particularly intelligent, and most of them are shy in captivity. Indeed, it is impossible to keep some species in confinement, as they batter themselves to death against the bars of their cage. The Vultures, however, become remarkably tame, showing no fear of human beings. They are very Crow-like in general actions and demeanour, being inquisitive and easily approached without taking alarm, even in the wild state, 
and without exception they do well in captivity. Although having enormous wings, they take the greatest care of them in order not to injure their feathers. The Eagles, on the contrary, batter themselves about, breaking their feathers, and not infrequently the wings themselves.

All these birds normally attain a great age, though just how long they live is not known. They are supposed to have but a single mate, and instances have been recorded of birds that remained alone for the rest of their lives, after having been deprived of their mates. Year after year they return to the same nest, adding to it each season until it becomes an enormous mass of trash and sticks. When possible, they build in inaccessible places, along the sides of steep precipices or in the tops of high trees.

The Eagle has been taken from time immemorial as a symbol of strength, and is used emblematically by nearly all civilised nations. The North American Indians paid great reverence to this bird, the braves when going to war wearing bonnets with Eagle feathers stuck in them and otherwise decorating themselves with the plumage.

One of the most remarkable of the Accipitres is the Secretary-bird, because of the very great length of legs, the long tail, and the long feathers which spring from the back of the head and neck. These last, from their fancied resemblance to a quill pen behind the ear of a secretary, or scribe, have given the bird its name. A native of South Africa, this bird is held in high regard there from the fact that its favourite food is snakes, many of which are poisonous, and conse- 
quently dreaded by all who have to live in that region of the world. The bird attacks and kills these reptiles by pounding them with its feet, using its wings as a shield against bites. On account of its valuable services it is often domesticated by the colonists of Africa. The Secretary-bird builds a huge nest of sticks, in which the nestlings remain for six months. See Plate 3, Fig. 13.

One of the most interesting Birds of Prey is the common Red Kite of Europe. It was once extremely. common, and was nowhere more plentiful than in London, where its numbers excited the comment of all foreign visitors. But that was several hundred years ago, when it was unmolested, being highly valued as a scavenger. It was also held in great esteem by the falconer, who hunted it with trained Falcons. No bird has a more beautiful flight than the Kite. See Plate 4, Fig. 17.

The Swallow-tailed Kite of this country is a very handsome bird, purplish-black on the back and wings, with head, neck, and under-parts pure white. The tail is extremely long and forked. Its flight is remarkably swift and graceful.

Other American species are the White-tailed Kite, distinguished by its black shoulders, greyish back and white tail, and the Mississippi Kite, by its slatecoloured back, black tail, and buff under-parts streaked with reddish and blackish colour.

The Harriers are peculiar in that the feathers of the face are arranged somewhat after the fashion that obtains among the Owls. The female differs remarkably from the male in colour, being brown above and 


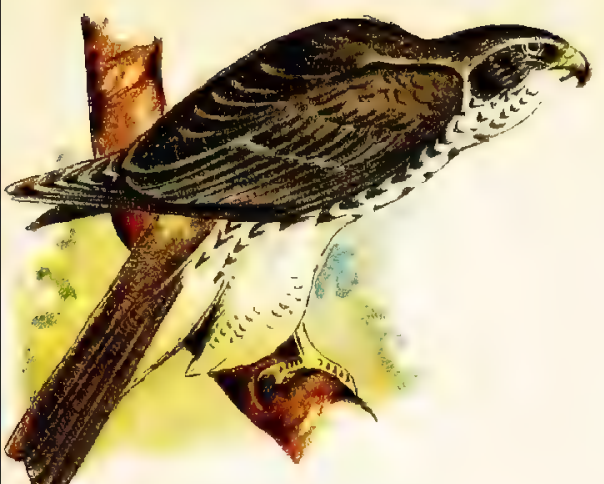

14. European Goshawk (Astur palumbarius).
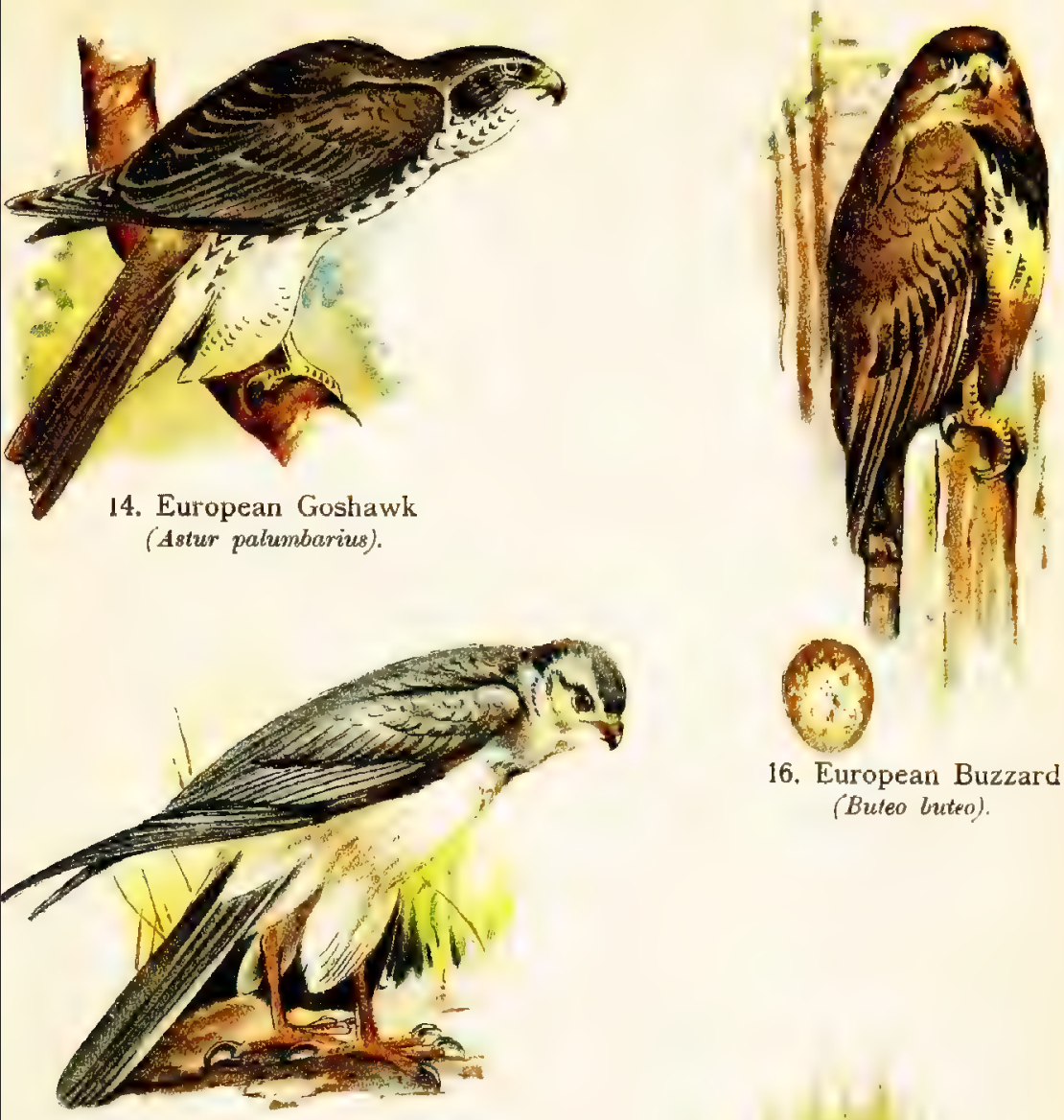

16. European Buzzard (Buteo unteo).

15. Hen Harrier (Cirms cyaneus).

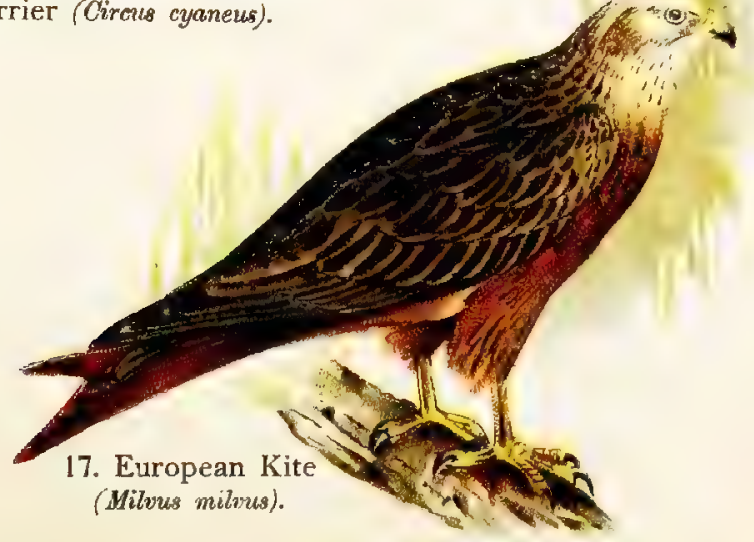


is 
having the tail banded with five dark bars, and on this account was at one time regarded as a distinct species, known as the Ring-tail. The males are bluish above, white below, with reddish spots. These birds are distinguished by the unusual length of their legs, wings, and tail. There are perhaps a dozen species distributed throughout the world.

The American Harrier, or Marsh Hawk, is almost identical with the European species figured. It is common throughout North America, and is one of our beneficial Hawks, feeding upon reptiles, mice, locusts and grasshoppers. In flight the females may be recognised by the reddish colour of the under-parts, spotted with darker; the males by the white spotted under-surface. See Plate 4, Fig. 15.

The Goshawk is an exceedingly powerful bird, having hind toes remarkable for their size and strength. In the old days it was much esteemed by falconers, the female, which is considerably larger than the male (as in all Birds of Prey), being flown at such large game as Geese and Herons, while the male was allowed to take smaller birds, such as Quails and Partridges. On account of its relatively short wings and long tail, it is able to turn and twist with wonderful dexterity. The American Goshawk is larger than the European, but resembles it in general colouration, differing chiefly in that the under-parts are freckled rather than barred. The plumage of the sexes is much alike. See Plate 4, Fig. 14.

The European Sparrow Hawk is a near relative of the Goshawk, but is a much smaller bird. Disparity of size in the sexes is nowhere more marked 
than in the Sparrow Hawks; they also differ greatly in colour, the female lacking the beautiful chestnut colour that is on the breast of the male. See Plate 3, Fig. 12 .

Here, the place of the European Sparrow Hawk is taken by two quite distinct species--the Sharp-shinned and Cooper's Hawk, both, however, bearing a very close resemblance to the Old World form. The bird known as Sparrow Hawk in this country belongs to a different section of the Hawk tribe. The two American species mentioned are similar in colourgreyish above, white barred with reddish below, with the shafts of the feathers blackish, and tail crossed with black bars. The tail of the Sharp-shinned Hawk is square at the end, while that of Cooper's Hawk is rounded. Both of these varieties are very destructive to poultry. Cooper's Hawk is considerably larger than the other species.

Among other common American Hawks are the Red-shouldered, so called from the rich reddish color of the lesser wing-coverts; the Red-tailed, from its reddish-brown tail, a larger species, but similar in habits; the Broad-winged, and the Zone-tailed.

We pass now to the Buzzards and Eagles, which blend one into the other.

The Common European Buzzard is still met with, although it is now a misnomer to call it "common." Sixty years ago it bred throughout Great Britain in considerable numbers, but to-day it is only occasionally seen. In the matter of plumage this species varies greatly, especially in the character of the markings. Some birds are a mixture of very dark and 
light brown, others are almost cream-coloured, while the markings on the breast often form a $\mathbf{T}$-shaped pattern.

The Buzzard feeds on field-mice, reptiles, frogs, and occasionally earthworms, varying this diet with small birds. See Plate 4, Fig. 16.

Perhaps the best known of the true Eagles is the Golden Eagle, the original species to which the name Eagle was given, a native of Europe and also of the western part of the United States. The name is derived from the supposedly golden colour of the plumage, but, as a matter of fact, this is a rich dark brown in tone. The legs are a brilliant yellow, and the eyes are dark brown and mild in expression. The bird itself, however, is one of the fiercest and most rapacious of the Order to which it belongs. It feeds upon hares and small mammals, Grouse and other birds; and when pressed to hunger it will even eat carrion. Of the numerous stories told of these birds carrying away children in their claws, none has ever been authenticated. The eggs of the Golden Eagle, two or three in number, vary greatly in colouration. See Plate 2, Fig. 8.

The Spotted Eagle is a bird which can be easily recognised by the white patch on the shoulders. It is a southern form, occurring in Southeast Europe, and ranging thence through Palestine to India and China. While some travellers describe it as displaying great beauty and majesty in its movements, and dauntless courage when foraging for food, others tell a different story. One writer assures us that it is a dull and stupid bird. "I have driven," he says, "the female off 
her eggs, and plundered the nest before the eyes of the pair, without either of them flapping a pinion to defend what even a little Shrike will stoop at once to save." Another writer says that he generally found these birds gorged with carrion, sitting stupidly around, when they would allow one to come within a few yards of them. See Plate 3, Fig. 10.

The White-tailed Eagle, or Sea Eagle, is found in the more northern parts of Europe and America. In general colour it somewhat resembles the Golden Eagle, but whereas in that species the legs are feathered to the toes, in the Sea Eagle the tarsus, or shank, is covered with small yellow scales. Very old birds have the head and neck almost white. The white tail is not acquired until the bird is several years old.

This bird lives, for the most part, on fish and offal cast up by the sea. Occasionally it preys upon hares and rabbits, and when much pressed by hunger it has been known to attack lambs. See Plate 3, Fig. 9.

A somewhat smaller bird than the preceding, but resembling it in character and in appearance, is the Bald Eagle of America, which figures as our national emblem. The female is larger than the male, but both have white heads and tails, the rest of the plumage being a dark chocolate-brown. The white-feathered head has probably led to the name bald. The bill is yellowish, the feet are a brighter golden yellow, the claws black. While extremely fond of fish, the Bald Eagle is not a particularly good fisherman, and does not scruple to take advantage of the Fish Hawk's greater skill. Watching its opportunity, the Eagle pounces upon the Fish Hawk as it rises from the water with 
3.

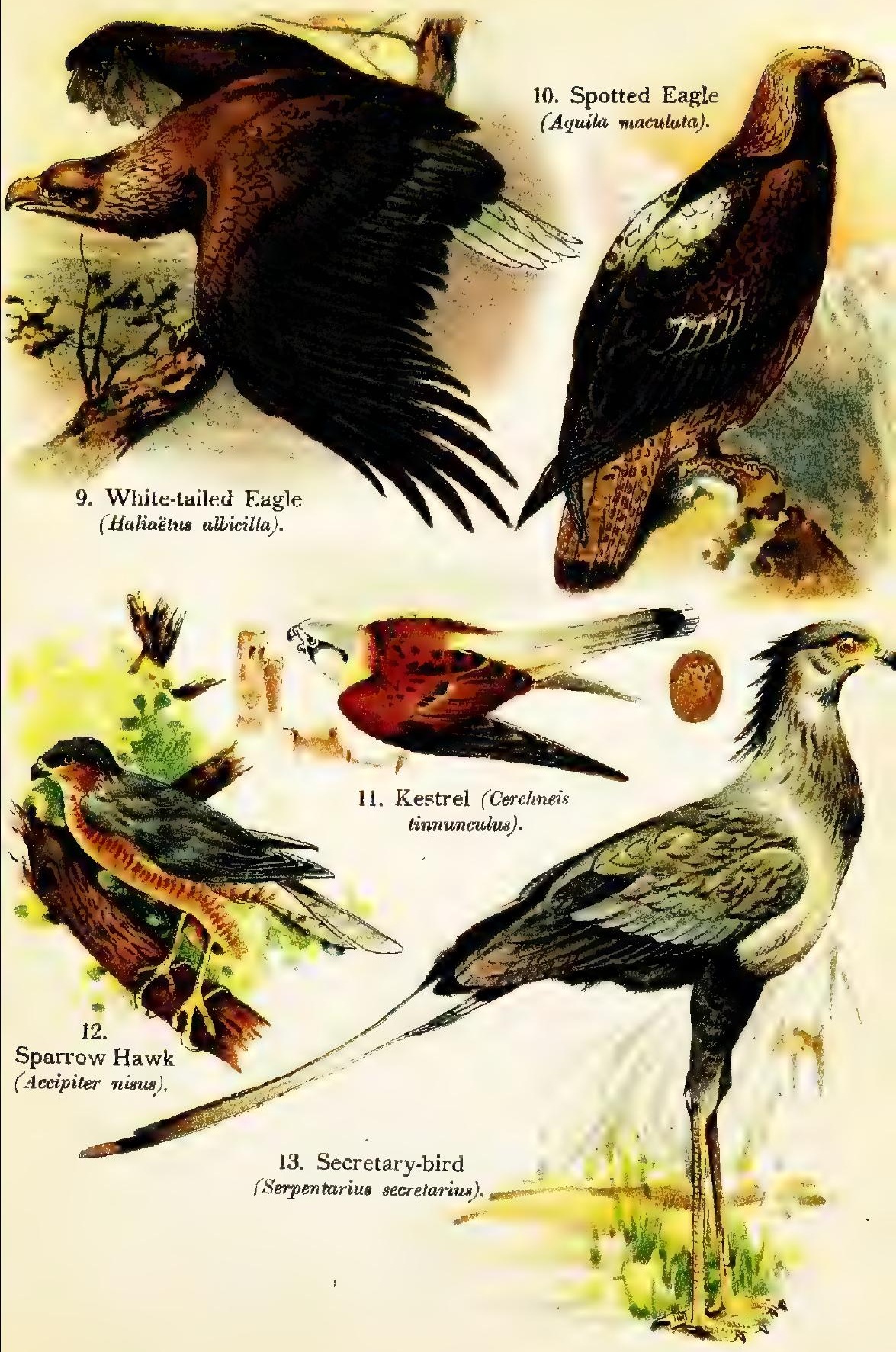



the finny prey struggling in its claws, and worries the smaller bird until it drops the fish, whereupon the Eagle, making a sudden downward dart, dexterously catches it, and carries it off to his nest to be eaten at leisure. In Florida one is treated to daily exhibitions of these contests between Bald Eagles and Fish Hawks. See Frontispiece.

The nest is usually placed in the top of some tall pine or other tree, in an exposed position, and consists of a mass of twigs and sticks roughly interwoven. It is occupied by the same pair of birds for a number of years; indeed, it is thought that Eagles mate but once, a pair continuing to live together until the death of one or the other of the birds. In Florida these birds are seen wheeling and screaming overhead at almost any time of the day. Strange as it may seem, the immature bird is at one period larger than the adult of either sex, being more loosely jointed and bulkier, and becoming more compact in form as it reaches maturity.

Audubon, in his "North American Birds," has given a thrilling account of the pursuit and capture of a Swan by a pair of Bald Eagles. When living prey is not available, this bird does not disdain carrion, and may often be seen, like the Sea Eagle of Europe, picking up the remains of dead fish and other offal cast up by the waves.

Probably the largest of the Eagles in actual measurement, although not in weight, is the great Kamchatka Sea Eagle, certainly one of the finest representatives of the genus. This great bird lives, as its name implies, along the shores of Siberia, and also in 
neighbouring portions of the United States, Alaska and the Behring Sea. It is particularly striking in appearance, having an enormous yellow bill, bright yellow feet, and rich dark brown plumage with certain of the wing-feathers snow-white. The tail is also pure white. The sight of one of these grand birds flying over the deep blue water of the ocean must be most inspiring. Owing to the inaccessibility of the region in which it is found, the life-history of this bird is comparatively little known, although it is safe to presume that in habits it resembles Eagles in general.

One of the most extraordinary of the Eagles, indeed of all Birds of Prey, is the great Harpy Eagle of South America, which inhabits, as a rule, the forests of the Amazon, although its range extends into Mexico and through Central America. The Harpy Eagle is short-winged and does not soar into the air to such a height as some of the other Eagles, though its power of flight is considerable. The primary feathers of the wing do not extend below the secondaries, so that when the wings are folded we do not see the sharp projecting points of the long wingfeathers extending across the tail, as in the Bald and Golden Eagles. In colour the adult is a deep bluishgreen on the back and pure white on the breast. The head is a delicate pearl-grey, and the neck is almost surrounded by a greenish band, the same colour as the back. The thighs are white, with small spots and lines of black upon them, and the under side of the wings is coloured in the same way, being pure white with numerous fine lines. The under side of the long tail is also white, but is banded by broad black marks. 
The most striking thing about the Harpy Eagle is the enormous size and strength of the feet and claws, the latter being some three inches in length.. The legs are as thick as the wrist of a man, and the claws may be driven through the thick and tough hides of sloths and monkeys, which are its principal prey. Sailing over the dense forests of the Amazon country, it drops lightly upon an unwary sloth or monkey that approaches the tops of the trees. It is also said to attack larger game, such as deer. The head of this splendid bird is adorned by a crest of dark greyishbrown feathers which it can raise and lower at will. The eye is a beautiful deep grey, and the bill is of an ashy hue. Its whole appearance is martial in the extreme, and onemight easily credit to this bird such stories of strength and courage as are wrongly attributed to the Bald Eagle. A magnificent specimen of the Harpy Eagle is now in the Washington Zoölogical Garden. Brought by steamer from South America to New York, it was carried through the streets of the city in an open cage, but instead of battering itself to death from fright, as would have been the case with most wild birds, it remained quietly seated on its perch, gazing fearlessly at the throngs of people passing. Since its confinement in Washington, it has exhibited the same indomitable character. It always seems greatly interested in visitors that pass by, and seated upright on its perch will turn its head quite upside down as it gazes at some particularly interesting individual. At times the Harpy Eagle utters a curious faint squeak, quite out of pro- 
portion to the great size of the bird. Little is known of its habits in the wild state, but it is said to nest in the tops of tall trees, like most mempers of the Eagle family. Individuals of this species are rarely seen in captivity, and still more rarely in good condition, being usually either wing-broken or injured so that they do not appear to good advantage. See Plate 42, Fig. 241.

The Caracara is a singular Bird of Prey found only in America, one species being somewhat common in our Southern States. The legs and wings are long, and the plumage is brown and white. Though nearly related to the Vultures, in appearance the Caracara is more like the Falcons, while in disposition and general habits it somewhat resembles the Crows, being both inquisitive and offensive in its demeanour toward other birds. It exhibits much intelligence and is easily tamed. A captive Caracara in the same cage with a Griffon Vulture, in a zoölogical park, was observed one day suddenly to sail over the larger bird, grasp it by the top of the head, and lift it completely from its perch. Apparently before the astonished Vulture could realise what had happened, the Caracara was skipping proudly about in a distant part of the cage. This bird exhibited great curiosity, and was continually pecking at the artificial-rock formation in its enclosure, moving about from place to place with a strange hopping gait. While extremely restless, it was entirely fearless. See Plate 42, Fig. 242.

It has been said that, unlike all other Birds of Prey of this class, the Caracara is unable to lift anything from the ground with its claws, the beak being always 
used instead, although when well clear of the ground the prey is dropped and dexterously caught in the talons. When a smaller bird is pursued and captured in the air, however, the claws are used, as with other Hawks.

The cry of the Caracara, uttered at frequent intervals, is quite unlike that of any other bird, having a peculiar clattering sound. The position assumed in giving utterance to it is also unusual, the head being thrown sharply backward until the crown touches the middle of the back.

The Falcons form a group by themselves, more or less distinct from the rest of the Birds of Prey, though the characters which give them this distinction are mainly anatomical. Their two most conspicuous external features are the long, pointed form of the wings, and the notch, or tooth, near the tip of the upper jaw, or mandible.

The Osprey, or Fish Hawk, is by some naturalists regarded as a connecting link between the true Hawks and Eagles and the Owls, because, as in the Owls, the hind toe of the Osprey is reversible; that is, it can be turned either outwards or backwards. See Plate 2, Fig. 6.

There is but one species of Osprey, and it has an almost world-wide distribution. It lives entirely on fish, which it captures by a sudden dive from a height, sending up a shower of spray as it plunges into the water to seize its victim. Occasionally it will drive its talons into a fish too large to be lifted, in which case the Osprey, unable to release itself, is dragged beneath the water and drowned. On order to hold the 
slippery prey more easily, the soles of the feet are provided with numerous rough spines.

It is a large bird, about two feet in length, with a wing-spread of more than twice as much. The general colour is greyish, or brownish, above, the under surface white, with dark spots. The colour, however, varies considerably in different individuals.

Living as it does exclusively upon fish, the nest of the Osprey is usually built near the water, in the top of a tall tree or an old building, and is used for many years in succession. Two or three white eggs blotched with brown are laid, and the young are much darker in colour than the adult birds. The Osprey is a most devoted mate and parent. This bird is particularly beautiful and graceful in flight.

The Kestrel is a little Falcon that is still quite common in many parts of Europe. It is easily recognised from its habits of hovering in the air on quivering wings, always facing the wind, and examining the ground with keen eyes in search of the mice and insects upon which it feeds. As with the Falcons generally, it builds no nest, but uses those that have been deserted by Crows and Magpies, or deposits its eggs on the ground, in cliffs or in hollow trees. See Plate 3, Fig. 11.

The male Kestrel when fully adult is a very handsome bird; the female is duller in hue, with back and tail closely barred. The young, as is so often the case when the parents differ in colour, resemble the female. The eggs, as with all the Falcons, are very richly coloured.

The place of the European Kestrel is taken in this 
5. King Vulture (Sarroorhamphus papa).

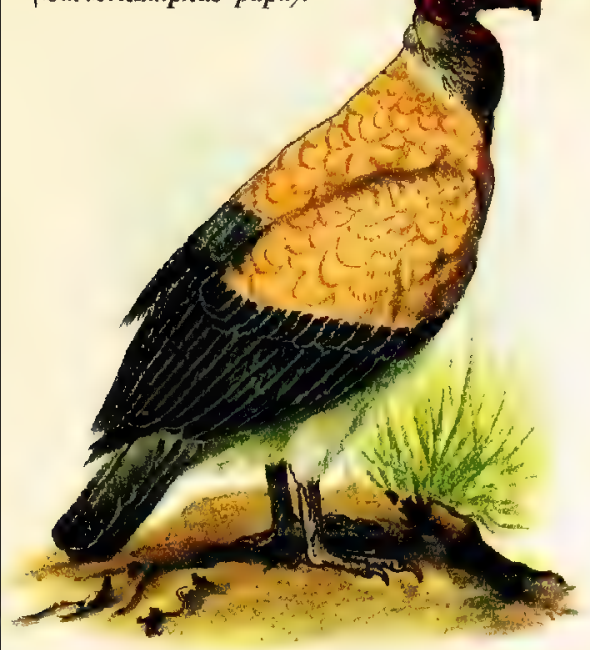

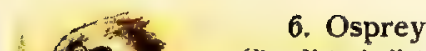

(Pandion haliaètus).

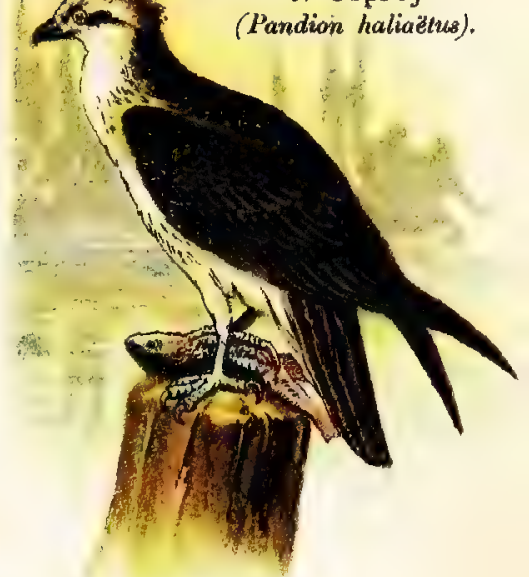

8. Golden Eagle

(Aquila chrysaëtus).

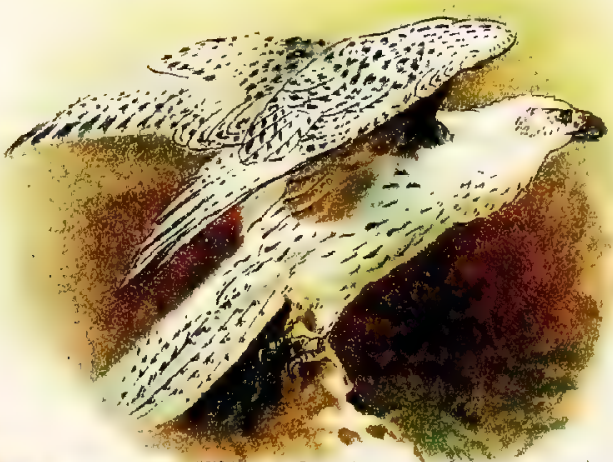

7. White Gyrfalcon (Falco islandus). 


\section{.}


country by the American Sparrow Hawk. As has been said, the Sparrow Hawk of Europe is quite a different species, and more nearly corresponds to our Sharp-shinned Hawk and Cooper's Hawk.

The American Sparrow Hawk is about eleven inches in length, and the sexes are quite different in colouration, the male being reddish brown above, with a few black marks, wings bluish and spotted, with a single broad black band across the tail, while the female is barred over the whole of the back, streaked with black on the breast, and has the tail crossed with numerous black bars. The bill is dark blue, the feet and legs are yellow.

This beautiful little Hawk is found in many parts of North America. It has the same habit as the European Kestrel mentioned above, of hovering on swiftly moving wings while seeking its prey of mice and smaller birds. It builds no nest, but frequently usurps that of the Woodpecker.

The Greenland Falcon, or Gyrfalcon, is one of the largest of this group, and is native to the Arctic regions, though occasionally found further south. In the old days when the sport of falconry was at its height, this bird was the most highly prized of all the Falcons. The general tone of the plumage is pure white relieved by black markings. Nearly allied to this bird, if not of the same species, is the Labrador Falcon, but it is at once distinguishable by the very dark colouring. The food of these Falcons consists of Ptarmigan and Willow Grouse, varied by lemmings and other small mammals. See Plate 2, Fig. 7 . The American Duck Hawk, or Peregrine Falcon, 
in many ways resembles the Gyrfalcon' It has a wide range throughout North America and a large part of South America. The sexes are coloured alike-bluish-slate above, a somewhat lighter tint below, the lower part of the breast and upper part of the legs barred with dark colour. The under-surface of the wings is also barred.

The Duck Hawk is very strong and swift in flight, and very fierce and aggressive in character. It pounces upon its prey from an elevation, easily capturing such fast-flying birds as Wild Ducks, and even attacking Geese when pressed by hunger.

From the Falcons we pass to the Vultures, a group which possesses many interesting points for consideration. Vulture-like birds taken as a whole are by no means all closely related one to another. Divided into Old and New World Vultures, the latter constitute a very ancient family, standing apart from the Hawks, Buzzards, Eagles, and Falcons. If we take these last as representing so many branches of a common stem, then the Vultures may be regarded as forming a similar independent stem, both arising, however, from a single trunk. The letter $\mathbf{Y}$ may well represent this. The different kinds of Old World Vultures may be pictured as forming so many branches from the lefthand, and the Hawks, Buzzards, Eagles, and Falcons as so many branches from the right-hand branch of the $Y$, the stem of which indicates that both main branches with their ramifications came from the same stock.

The New World Vultures, however, form a group by themselves; they are the terminal branches of a 
separate trunk, which we may suppose grew out from the very root of the $\mathrm{Y}$-shaped tree. They may at once be distinguished from all other birds of prey by the fact that the nostrils are pierced quite through, whereas in the rest of the birds of prey they are divided by a partition; further, the feet and claws of the New World forms are less Hawk-like.

Of the Old World Vultures, three very interesting species are figured.

The smallest members of this family are the Egyptian Vultures, found in considerable abundance in the Mediterranian countries and in Africa. Though it has the reputation of being an exceptionally foul feeder, this bird is most useful in removing offensive matter which in such hot climates would breed disease. The Egyptian Scavenger also preys upon rats and mice, snakes, lizards and even insects. See Plate 1, Fig. 2.

The Griffon Vulture is a large bird, having an extreme length of about three feet six inches. It is common in the southern part of Europe, particularly in the neighbourhood of Gibraltar, nesting in colonies in the cliffs. See Plate 1, Fig. 3.

Probably the most interesting of all this family is the Lammergeier, or Bearded Vulture, whose range extends through Southern Europe, Central Asia, the north of Africa, and into China. Though at one time frequently met with in Switzerland, it is now almost unknown in that country. It is the largest of the Old World birds of prey. See Plate 1, Fig. 4.

One of the most striking features about this bird is the brilliant vermilion colour of the outer coat of 


\section{BIRDS OF THE WORLD}

the eye-the part corresponding to the whites of human eyes; the rest of the eye is golden yellow with a black pupil. There are curious tufts of stiff feathers like bristles at the base of the bill. The plumage is brown streaked with white.

The Lammergeier is very powerful in flight, traversing great distances in search of its food, which consists of small mammals and carrion. Bones appear to be a great delicacy, and to smash these the bird is said to drop them from a great height upon rocks below.

The King Vulture of the New World is a wonderful bird that is by no means well known. It receives its name from the fact that it drives away from a carcass the smaller birds of prey until its own appetite is sated. It is found in the higher mountain regions of South and Central America, and occasionally comes as far north as Texas and Florida. One of the most remarkable features of the male is the curious fleshy wattle which surrounds the beak, while the bare skin of the head is most brilliantly coloured with varying shades of orange, purple, crimson, and black. The upper parts of the body are creamy white, the long wing- and tail-feathers black. The plumage of the female is much less conspicuous, the upper parts being dark instead of white, and lacking the brilliant colours on the head. See Plate 2, Fig. 5.

The South American Condor is a near relative of the King Vulture, but greatly its superior in size. With the possible exception of the succeeding species, it is the largest of all Birds of Prey. See Plate 1, Fig. 1. 


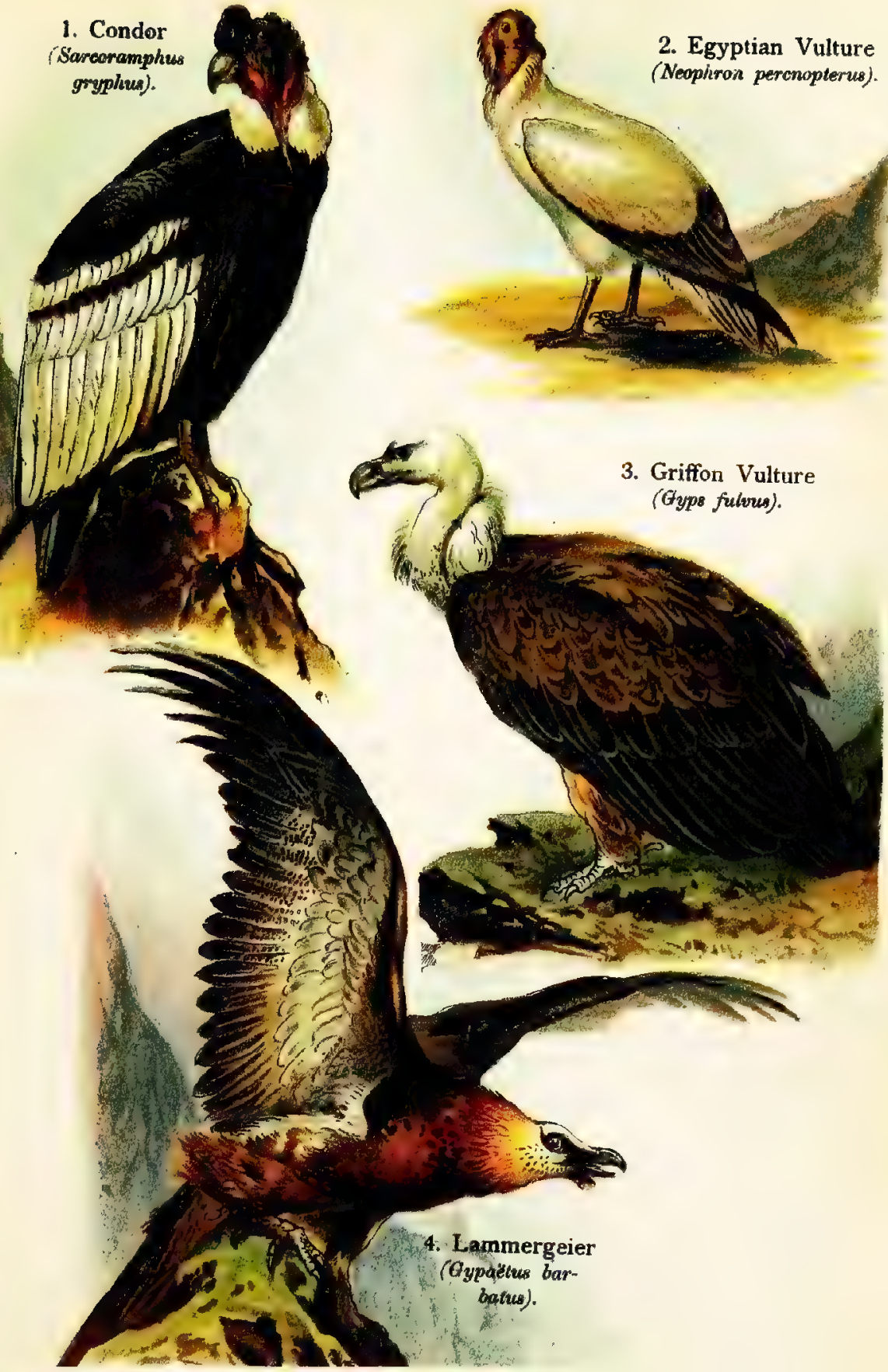


- 
The general colour is ashy grey, with considerable white in the wings; there is a ruff of soft white feathers, or down, about the neck, except in front, and the head of the male is adorned with a great fleshy wattle at the base of the beak. Condors feed upon carrion mostly, but show a marked liking for fresh meat when obtainable. Apparently, however, they never kill for themselves. Like other Vultures, they gorge themselves when food is plentiful, and at such times are often taken by the natives of the country by means of lassos.

The California Condor equals, if, indeed, it does not exceed in size the South American species. In general form they are not unlike, but the more northern bird lacks the white collar about the neck, having instead a ruff of dark, pointed feathers. It also is without the curious wattle that grows from the top of the head in the other species. The plumage is generally ashy grey in colour, with a kind of bloom over it. The feet are very large. These birds nest in high cliffs along the coast of California. The young birds are clothed in pure white down, which gradually deepens to grey as they grow older.

Owing to their destruction by hunters, and to poison set out by sheep-herders as protection against wolves, these birds are becoming rare in the regions where they were formerly common. The Condor is absurdly tame, allowing itself to be approached by man even when at large. Fortunately, it thrives in confinement, largely owing to its lack of fear, and it is a remarkable fact that such great birds, accustomed to flying over vast mountain regions, should do so 
well and keep themselves in such perfect condition in small cages often not more than six feet square. It is with much satisfaction that one looks at this magnificent bird, seated on a rock or tree in its enclosure, absolutely at ease, and with every feather lying smoothly like metal plates on its back.

The Turkey Vulture, or Turkey Buzzard, as it is commonly called, has rather an extensive range in America, but as a rule it is not found farther north than Pennsylvania and New Jersey. It is quite common in the region of the city of Washington and farther south. In general appearance it somewhat resembles a hen Turkey, the skin of the head and neck being of a reddish colour blotched with white. The plumage is rusty black in colour, the under-surface of the wings a light grey, the bill whitish. The feet and legs are red. The eye is bright and piercing and quite intelligent in expression. See Plate 41, Fig. 243.

These birds are extremely useful in ridding the ground of fetid matter that would otherwise pollute the air, and consequently they are rigidly protected. They are almost exclusively carrion-eaters, although like other Vultures they will eat fresh meat when obtainable. Their sight is remarkably keen, and they are often seen flying over wooded or marshy country, seeking with their sharp eyes for the carcasses of animals. After these birds have eaten heavily, they sit, like the Old World Vultures, in a drooping attitude, with wings hanging listlessly at their sides. The object of this is probably to air and cleanse the feathers, but when in this position they have a most depressing effect upon the observer. 
These birds are strong and beautiful flyers, soaring in the air for hours at a time without flapping their wings. When rising from the ground, however, or starting from a tree, they flap heavily several times in order to gain momentum for flight, but once on the wing they rise and fall without perceptible motion of the wings. Owing to the rather flimsy character of the feathers, the Turkey Buzzard has a wobbly or teetering appearance when a puff of wind strikes it. But this effect is of course more apparent than real, as by a single stroke of the wings the bird regains its equilibrium and sails gracefully on in an undulating course. Although living in the vicinity of human habitations, it is always a shy and wary bird.

In the far Southern States the Turkey Vulture's reign is disputed by that of the Black Vulture, sometimes called Carrion Crow by the natives of that region. In form it is somewhat similar, but is more compact, and the feathers are richer and more glossy in tone. The colour is a deep black, almost blue, and slightly iridescent like that of the Crow. It is a stronger flyer than the Turkey Vulture, the primaries of the wings being much stiffer, and on occasions it rises so high as to become a mere speck in the air, wheeling in great circles over the region it inhabits. It is more common in the Southern States than the other species, and in the streets of Charleston, South Carolina, may be seen in great numbers gathered about the slaughter-houses and greedily devouring the offal thrown out from them. Unlike the Turkey Vulture, it is extremely tame, allowing itself to be closely approached without taking alarm. 


\section{CHAPTER VII}

\section{The Fowl-Like BrRds}

\section{ORDER-GALLIFORMES}

THIS Order includes an enormous number of birds, more or less nearly related to each other. In certain groups, common anatomical characters are apparent externally in the form of beak and legs, and in the general shape of wings and body. In all, the upper portion of the beak is curved and completely overlaps the lower; while the legs have strong toes and short, blunt claws, forming admirable digging and scratching tools. As a rule, the Gallinaceous or Fowl-like birds have legs completely covered with scales and armed with a pair of powerful spurs; but some have very short legs, feather-clad, and without spurs.

These birds are divided into two great groupsone in which the hind-toe is on a level with the other toes, and the other in which the hind-toe is at a higher level than the rest. To the former belong the curious Mound-birds, or Megapodes, of Australia, and the equally curious Curassows and Guans of America, all others belonging to the group which has the hind-toe at a higher level than the other toes. In both sections, 
the young are hatched clothed in down, and are able to run about immediately after leaving the shell.

The Mound-birds have very large, strong feet, and with them they throw up huge mounds of earth and decaying vegetable matter, in which they deposit their eggs, digging holes for their reception a number of feet below the surface of the ground. The male bird is said to assist the female in making these mounds, but after the eggs are laid, apparently no further attention is paid to them by the parents, and they are hatched by the heat generated in the decaying vegetation. But little appears to be known about the habits of these strange birds.

The Curassows are somewhat Turkey-like in form. They are forest-loving birds, nesting in trees, and are found in the tropical portions of America. There are many species. Perhaps the commonest is the Globose Curassow, which is frequently seen in captivity. It is almost black in colour, with greenish iridescence on the back and breast, and has a large crest. These birds go about in flocks, and perch high up in the branches of trees, where they build their roughlyshaped nests. See Plate 41, Fig. 244.

The only species of Guan known in North America is the Chacalacca, so called from its cry. In the Guans the bill is longer and wider than in the true Curassows. The two forms are closely related, but the Gruans are more solitary in habits. They are distinguished by the bare, bright red skin of the throat, which may be expanded at will.

The largest of the Gallinaceous birds is the Turkey, native to North and South America. It is one of the 
oldest types of the Order to which it belongs. The Mexican Wild Turkey is the species from which our domestic Turkeys are descended. Among the many remarkable features of the male Turkey are the curious tuft of hair-like feathers attached to the breast, the bare and brilliantly coloured head and neck, and the long, fleshy, finger-like appendage, or wattle, hanging down over the beak, that can be increased in size at will. This bird is very large, individuals sometimes weighing as much as thirty-five pounds. See Plate 27, Fig. 155.

The actions of the Turkey-cock when "strutting" are very remarkable. The head is drawn sharply backward, the wings dropped, the tail spread like a great wheel, a deep reddish colour suffusing the naked skin of the neck and head, and the stiff primaries of the wings drawn along the ground with a sound like distant thunder.

The male Turkey is irascible in disposition, easily excited to anger, and very aggressive. There are many instances of children having been injured by these great birds, whose size and weight render them formidable.

The hen Turkey is not so large as her mate, and is not so brilliantly coloured. She is extremely wary and suspicious, especially when she has to protect her young-ungainly-looking little creatures, with long necks and long legs. They are able to walk for many miles, the mother seeming to delight in taking long pilgrimages in search of new feeding-grounds.

When wild, the Mexican Turkey is extremely shy and ever on the alert, and the sportsman who can add one of these great birds to his game-bag may justly 

feel proud of his achievement, for it is only by the shrewdest strategy that he can approach within shooting distance.

Closely related to the preceding form, although differing in some minor particulars, is the Eastern Wild Turkey, which, in consequence of much hunting, is becoming very rare. The colour of this bird is somewhat darker, in general, than that of the Mexican variety, and it lacks the light colour on the upper surface of the tail. It is a finer and trimmer bird than the domesticated species, but in captivity would no doubt soon acquire the over-developed and heavy form of the other. Another very beautiful variety is the Honduras Turkey.

The Guinea-fowl is a native of Africa. It is easily domesticated, and is commonly seen in our farmyards. This bird is almost reptilian in certain characters. In walking, the back is much arched, the head dropped low, almost touching the ground, and at a distance a flock of them looks not unlike quickly moving tortoises. See Plate 27, Fig. 154.

The colour pattern of the plumage is quite wonderful. The body tone is a delicate grey, and each feather is covered with numerous pure white dots, making a most complete and intricate design. The naked skin around the eye is white, and the wattle at the base of the bill and the under-throat are a bright red. The Guinea-fowl is a very restless bird, continually moving about and uttering its monotonous cry-one that is apt to "get on the nerves" when listened to for hours at a time. On account of their alertness, Guineas are often kept by farmers as guar- 
dians of their poultry; at the slightest sound they raise their voices and often give warning of the approach of a Hawk. The flesh is dark in colour, and has a strong, gamey taste.

Besides the species represented, there are numerous others known to science. Perhaps the most beautiful is the Vulturine Guinea-fowl, in which the grey colour is replaced by a delicate blue, and the feathers are very long.

The Pheasant tribe include some of the most brilliantly coloured birds in existence. They are natives of China and India, some species extending into the islands of the Indian Ocean.

The best-known Pheasants to the Western world are the Common and Ring-necked Pheasants of Europe. Fossil remains show that they at one time lived wild in Europe, and the present species may have descended from these; but it is more likely that they were introduced into England by the Romans. The so-called Common Pheasant, the species figured, is now very rare, because it has interbred with other species which have been allowed to run wild. But the Ring-necked Pheasant is the principal game-bird of England and the continent of Europe, being kept in large parks, or preserves, and shot at certain seasons of the year. The eggs are usually placed under domestic hens, as they are considered better mothers than the female Pheasants. Great care is taken of the young birds in order to bring them to maturity. See Plate 26, Fig. 150.

The male Ring-necked Pheasant is rich and pleasing in colour, a splendid golden tone covering the 
whole body, the feathers arranged like scales. Around the neck is a pure white ring, and the skin about the eye is a brilliant red. The females are much duller in hue, although they have some beautiful feathers.

'These birds have been introduced into the United States, and in certain parts of the country, notably in Oregon, they have multiplied to an extraordinary extent. The flesh is highly prized. The Pheasant is not a satisfactory bird to keep in close confinement, as it never loses its extreme shyness, and is apt to injure itself by flying against the bars of its cage.

The most brilliantly coloured member of this family is the Golden Pheasant, a native of China. On account of its resplendent plumage it is usually seen in collections. It is impossible to give any adequate idea of the brilliance of the feathers, which glisten as if illuminated from beneath, and the various plates, bars, and scales arranged over the body of the bird make it seem as if clothed in armour. A study of the figure of the Golden Pheasant will do more than words to indicate this remarkable colouration. The male has the ability to spread out the long neck-feathers into a wide, circular cape. See Plate 25, Fig. 146.

The Silver Pheasant is another form commonly seen in aviaries. It is now rare in a wild state, and little is known of its habits, except in confinement. The upper surface of the body is white, covered with fine black lines; the breast is dark, and the long tailfeathers are white. See Plate 26, Fig. 151.

The Impeyan Pheasant is probably the most brilliant of all iridescent birds, the colours ranging through the spectrum from orange to yellow. The 
head and neck are greenish, the back a shining purplish-blue, with red and green iridescence. Across the tail is a wide band of pure white, the tail itself being brownish, barred with darker colour.

Other well-known species of Pheasant are the Reeves and the Lady Amherst.

But the largest, and in some respects the most conspicuous, of this family is the Argus Pheasant, a native of the Indo-Malay Peninsula. It is remarkable for the enormous length of the inner flightfeathers of the wings, while the tail-feathers are also extremely long. But it is not so much the great length as the wonderful and complicated pattern on them that makes them so extraordinary. Large eyelike marks are placed at regular intervals along the main shafts, so wonderfully shaded as to look like balls lying loose within sockets, with a wonderful network of spots and lines about them. The colours are rich brown and white. When the male bird displays, he raises and spreads his wings so that they form a great circle over his back, the wings being raised at the same time. See Plate 26, Figs. 152, 153.

Perhaps the crowning glory of this family is the Peacock, a native of India, and one of the most marvellously coloured of all the feathered tribe. It is distinguished at once by its long train of feathers, which drag on the ground when the bird is walking. Each of these is a gem in itself, being finished at the tip by a large expanded web, in the centre of which is a huge eye-like form. In a mass they seem to shimmer and glow with all the prismatic colours-red in some lights, green and gold in others. The "eyes" are a 

beautiful blue. The Peacock is a very graceful bird, the neck long and slender, the head surmounted by a most beautiful and delicate crown, or crest, of fine lace-like feathers. Most of the body is a deep rich blue, in texture like the finest velvet, and shading almost to black upon the breast and upper parts of the legs. The upper feathers are a delicate grey, covered with fine dark lines, while the stiff and long flight-feathers are a light reddish-brown, and not iridescent as are the other feathers. It is only when the Peacock flies, or stretches its wings, that these red feathers become visible; at other times they are folded closely against the back. See Plate 25, Figs. 148, 149.

When displaying, the Peacock raises its gorgeous train-which, of course are not the true tail-feathersover its back in a half circle, and spreads it to the fullest extent.

Although so magnificent in plumage, the Peacock is not a singer, its voice being extremely harsh and disagreeable, and sounding not unlike the magnified "meow" of a cat.

These birds are easily domesticated, and become very tame, and it is only because they are so common that their beauty is not more appreciated.

The nearly related Javan Peacock differs from the common species chiefly in having neck-feathers of enormous size, so that the neck has the appearance of being clothed in large, overlapping scales.

Our domesticated Fowls are really near relations of the Pheasants. They are supposed to have descended from the wild Jungle-fowls of India, and by 
careful breeding for centuries man has produced from this bird many remarkable varieties. Indeed, the Leghorn and the Game-fowls retain much of the original character of the Jungle-fowl, although in them, as well as in most other domestic breeds, the comb and wattles are much more developed. The cocks of the Game-fowls are used for fighting, and for many years, in England and in other countries, they were regularly bred and trained for this purpose. The largest of the domestic Fowls are the Brahmins and the Cochin Chinas. The latter breed was introduced into England about 1850, and soon was in great demand, the eggs bringing very high prices. Perhaps the best-known breed in this country is the Plymouth Rock, a large, heavily made fowl, curiously mottled with grey and white. Among the most beautiful are the silver-speckled and goldenspeckled Hamburgs. 'Polish-fowls are distinguished by their large topknot of long feathers, which fall down over the eyes like the hair of a sky-terrier, in some cases almost blinding them. In Japan for many hundreds of years has been bred a curious species called the Long-tailed Fowl, in which the abnormally lengthened tail-feathers sometimes measure as much as twenty feet. These feathers are sometimes kept carefully wrapped in paper to protect them from injury. See Plate 27, Fig. 156.

Domestic Fowls have a great variety of calls, or notes, which any one may soon learn to interpret. The cluck of the mother hen when she takes her chicks out to hunt for food; the peculiar sound known as "singing," in which she indulges after having been 


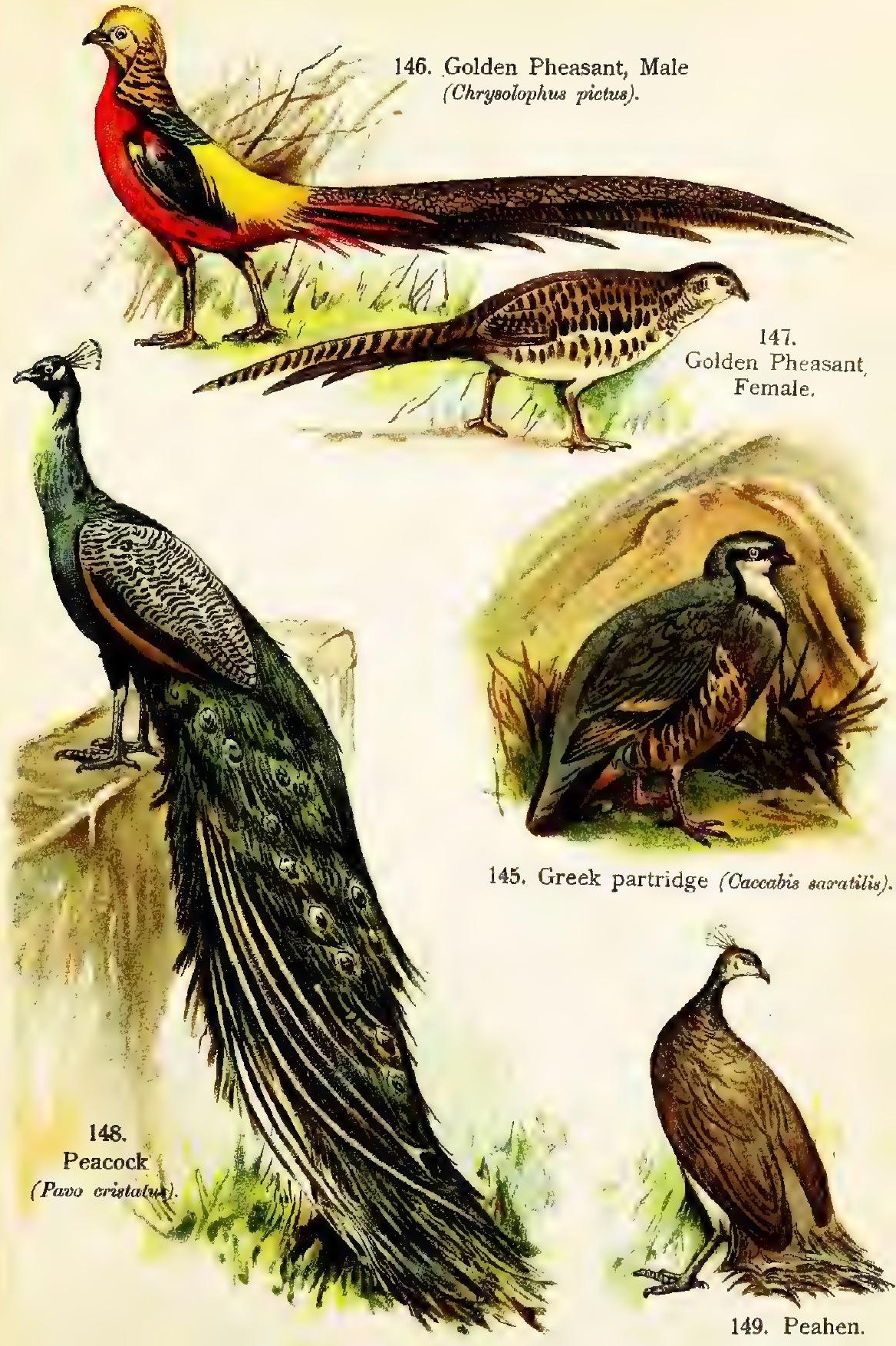




$$
\checkmark
$$


fed and in fine weather, the "cackle" that follows the laying of an egg; the cry of warning that instantly brings her chicks to cover under her wings when a Hawk appears overhead-are all familiar sounds of the poultry-yard. The "crow" of the cock, usually given when he goes to roost at night, early in the morning, and after he has gained a victory over another cock, is also well known.

Although originally from warm climates, domestic Fowls are able to withstand very low temperature, especially if protected from severe winds and from dampness.

Between the Pheasant tribe and the Partridges and Quails of the Old World there is no very sharp division. True Partridges and Quails are not met with in America, but they are represented by birds that closely resemble them in many particulars.

The Common Partridge of Europe is also sometimes called the Horse-shoe Partridge, from a horseshoe-like mark on the breast in both sexes. The female may always be distinguished by the buff crossbars on the smaller wing-coverts. In eastern Siberia this bird is replaced by the Bearded Partridge, in which the throat is decorated with long beard-like feathers. See Plate 24, Fig. 144.

The Common Red-legged Partridge ranges over southwestern and western Europe and Great Britain.

The Red-legged Rock Partridge is a native of the mountains of southern Europe, from the Pyrenees to the Balkans, and differs from the Common European Partridge in the absence of white on the flanks 
and of black spots on the chest. See Plate 25, Fig. 145.

Quails are frequently described as miniature Partridges, and the two families are very closely related. The Common European Quail is found in many parts of Europe and northern Asia. These birds migrate in the spring in vast numbers from Africa to various parts of Europe, and this is the season for hunting them. The European Quail has been imported into the United States, but has failed to thrive in this country. See Plate 24, Fig. 141.

Their place here is taken by the Grouse and the Bob White, of which there are many varieties. In the northern States the Grouse is called "Partridge"; in the southern States the same bird is called a "Pheasant." The Bob White of the North is known as "Quail," while in the South it is termed "Partridge." But, as has been said, there are no true Partridges and Quails in America.

The Ruffed Grouse is a large bird, measuring nearly eighteen inches in length, and its plumage is a mixture of greys, browns, and buffs. On the neck of the male are long, purplish-black feathers capable of being erected. This is the principal Grame-bird of our Eastern States. Its home is in the dense coverts of the woods, and so closely does it resemble the ground colour and dead leaves that it is impossible to see a flock until it takes flight. The suddenness with which they start from the ground is very startling and disconcerting to a novice at shooting. They spring into the air with a loud whirring sound and fly so rapidly that they are almost instantly lost to 

view. In winter scales grow out from the sides of the toes, enabling the bird to walk on soft snow.

In the spring the male Ruffed Grouse goes through with the curious performance known as "drumming." Standing upon some convenient log, he raises his tail to the fullest extent and spreads out the ruffs at the sides of his neck, at the same time beating the air with his wings, quickening the strokes until they move with lightning-like rapidity, producing a curious rumbling sound much like that of a drum. This is done for . the edification of his mate, who stands watching the performance with apparent indifference.

The Pinnated and the Sharp-tailed Grouse are found in many parts of the Middle West, and the name "Prairie Chicken" is somewhat vaguely applied to both in different sections. These birds, too, have singular actions at the mating season, at such times inflating and exhausting the large orangecoloured sacs at the sides of the throat and raising the tail high over the back.

Other well-known species are the Sage Grouse, a very large form, but one whose flesh is not especially prized, the Canada Grouse, and the Dusky Grouse, found in various parts of the country.

The Ptarmigan is another species of the Grouse family found in the northern parts of America and Europe. This bird has a most remarkable system of protective colouration adapted to each season of the year. In winter, when the ground is covered with snow, the plumage is white; as spring approaches, this is gradually replaced by a brownish coat, which is worn until the autumn, when the moult again takes 
place and the bird becomes a mixture of brown and white, this gradually giving place to the winter coat of snow-white. Thus the Ptarmigan is at all seasons practically invisible in its environment. This and other species are remarkable for their extreme tameness, allowing themselves to be closely approached and actually touched without taking flight. Whether this character is due to lack of fear or stupidity it is difficult to say, but it is one that is certainly not shared by its near relative, the Ruffed Grouse. See Plate 24, Fig. 143.

The Willow Ptarmigan is also found in the northern parts of both continents.

Largest of the Game-birds of Europe is the Capercailzie, or Cock of the Woods, also belonging to the Grouse family. At one time common in Great Britain, it became extinct, but of late years has been reintroduced into Scotland, where it is found in considerable numbers. It is not an inhabitant of America. This is a woodland bird, living in trees, and in this respect unlike most other Game-birds, which seem to prefer the ground. The males go through with many curious performances during the breeding season, when they are so engrossed as to be unconscious of the approach of enemies, and are often shot down. The female is smaller than her mate, and quite dull in colour. See Plate 24, Figs. 138, 139.

The Black Grouse is a particularly handsome bird, remarkable for the curious shape of its tail, which is divided in the middle, the feathers curving to right and left, like hooks. There is a brilliant, red skin 
around the eye, as in some of the Pheasants. See Plate 24, Fig. 142.

The Hazel-hen is a native of Europe and northern and central Asia, and its flesh is much esteemed for food. It bears some resemblance to our own Ruffed Grouse. See Plate 24, Fig. 140.

The Bob White has well been called the king of our American Game-birds. It is small, about ten inches in length, and the plumage renders it extremely inconspicuous, when on the ground. The male has a white throat and a white stripe over the eye; the top of the head is reddish, varied with black and white; the back and wings are a mixture of delicate greys and browns; the lower parts are yellowish-white, crossed with delicate lines of black; a black mark encircles the white of the throat; the flanks are reddish, barred with black; the upper part of the tail is bluish-grey. The sexes are similarly coloured, except that the female has more yellow in the plumage.

Bob Whites live more in open country than the Grouse, run in large flocks, and when flushed fly in different directions. Their speed is not so great as that of the larger Game-bird. When alarmed, Bob Whites "lie close" on the ground, instead of rising in the air, trusting to their colouring to remain invisible. Setters and pointers, dogs having remarkably keen scent, are trained to hunt these birds, advancing slowly upon a covey until it rises with a great whirring of the short, rounded wings. These dogs are trained to drop at the sound of a gun, and then to retrieve, or bring back to their master in such a way as not to injure them, the birds that have been shot. 
In the West are found several species of "Partridge," some of great beauty. One called Gambel's Partridge has the upper parts of the neck and back a delicate fawn colour, the breast being somewhat lighter. In the middle of the breast is a large, irregular blackish patch of feathers. The sides are a rich reddish-brown, streaked with pure white. The most striking feature of this bird is the long, forward projecting crest of black feathers, normally drooping over the bill. The top of the head is reddish, and the feathers are very soft and velvety in texture. The face and under part of the throat are deep black, the eyes very dark brown, and around the face is a narrow line of pure white. The feathers of the body are rounded, and have much the appearance of scales. See Plate 41, Fig. 245.

The California Partridge is quite similar in colouring to the Gambel, and has also a forward curving crest of black feathers. Other Western species are the Scaled Partridge, the Mountain Partridge, and the Plumed Partridge. 
. 


\section{CHAPTER VIII}

\section{Cranes, Rails, and Bustards}

\section{ORDER-GRUIFORMES}

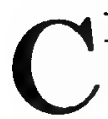

RANES, Rails, and Bustards, though very different in external appearance, are really closely related. Cranes and Rails are marsh birds, while Bustards frequent sandy wastes; Cranes are wading birds, but Rails swim and dive with ease. All are vegetable feeders, and the diet of Cranes and Rails is varied by insects and molluses, such as snails, slugs, and worms, and Bustards also eat small mammals, such as mice, and reptiles.

The Common European Crane is a large and very beautiful bird, measuring about four feet in length. In Cranes the windpipe, instead of running straight down the neck to the lungs, passes first into a large chamber in the keel of the breast-bone. After forming a coil or loop there, it emerges and passes backwards to the lungs. By the increase in length thus gained, an extremely loud and resonant voice is produced. See Plate 29, Fig. 161.

These birds have long legs and long necks, and are not unlike Herons in general appearance, although the form of the head, as well as the colouration, differs in different species. But three out of the fifteen or more existing species of Cranes are found in America. 
The Whooping Crane winters in the Gulf States, but breeds farther north. It is a large white bird, with primaries, bill, and legs, black, top of head and sides of throat red.

The Sandhill Crane is a smaller form also found in the Southern States, especially in the pine barrens of Florida, some distance inland from the coast. The body colour is a beautiful bluish-grey, the top of the head a soft, deep red. The bill of Cranes is used both as a digging instrument and a weapon of defence, and with it they also make a strange clattering noise, when excited. The Sandhill digs enormous holes in the ground in search of food. Its voice is very loud and resonant, and may be heard at a great distance as the bird flies from place to place.

The Little Brown Crane is a smaller and rarer species than either of the preceding. It closely resembles the Sandhill Crane.

Two very beautiful species found in Africa and frequently seen in captivity, are the Demoiselle, a small bluish-grey bird, with long feathers trailing from the tail, and the Crowned Crane, remarkable for the tuft of feathers on its head. See Plate 34, Fig. $19 \%$.

Included among the Crane-like birds, although bearing a strong resemblance in both appearance and character to the Hawk tribe, is the Seriema, of South America. It is not unlike the Secretary-bird of Africa, and feeds upon snakes, killing them in much the same manner, by pounding them with its feet until they are reduced to a pulp. It also eats small mammals, such as mice and rats, and further varies its diet with fruits. Although able to fly well, it lives on 
the ground, in the grass of the pampas, and runs with great speed, having very long legs. See Plate 42, Fig. 245.

In colour the Seriema is a dull brown over the greater part of the body, somewhat reddish on the back and the upper coverts of the wings. The feathers are thin and loosely attached, as in the Herons, and the long neck-feathers are so fine in texture as to have almost the appearance of a mane, falling over the back and sides of the neck. The inner web, only, of the primaries is barred with dark colour. The bill and legs are a delicate reddish colour, and the eye, which is fierce and Hawk-like in expression, is a beautiful grey, and is shaded by long and delicate lashes. A curious character of this bird is the inner toe, which is carried free of the ground and bears a very long, sharply recurved claw like that of the Eagles, the other claws being much less pointed and straighter. Growing from the base of the bill, but not extending to the crown, are a number of sparse, hair-like feathers, giving the bird a very peculiar appearance.

The Seriema has a most remarkable call, or cry, the noise being extremely loud and piercing, and almost deafening to one standing near the bird. In uttering it, the head is dropped back against the shoulders and the mouth is held widely open, the sound actually seeming to be pumped, or squeezed, from the throat.

The Common Trumpeter, or Golden-breasted Trumpeter, is another very interesting South American bird, that has no very near relatives, and so con- 
stitutes a family by itself. Like the Seriama, however, it is placed by ornithologists in the Order of Crane-like birds. Its power of flight is feeble, so that most of its time is spent upon the ground, and like the preceding form, it is a very swift runner. These birds are easily domesticated, becoming very much attached to people and living peaceably with domestic Fowls. Trumpeters are somewhat gregarious, being found in small flocks. Their call, uttered at night and by a number of birds at the same time, is loud and harsh.

In form the Trumpeter is not unlike a small Emu, having a rounded back and long neck, but it partakes of the characters of other species as well. The head and neck are almost jet black, and on the breast is a patch of brilliant iridescent feathers which seem to differ in texture from the rest of the plumage, being much stiffer and harsher. This iridescence is entirely bluish-green, and has no suggestion of golden colour in it. The back and upper tail-coverts are a warm grey, and bill and legs greyish-black. The eye is very dark and shining, and looks not unlike a shoe-button sunken in the dense plumage of the face. The feet are large for the size of the bird, and are evidently formed for scratching.

The Rail tribe are mostly small birds, of shy, skulking habits and feeble flight, but with strong legs, and able to run with great speed through the marshes in which they live. One of the smallest is the Little Crake, a native of Africa, but occasionally seen in Great Britain. The Spotted Crake is common all over Europe during the summer, but returns to Africa to winter. See Plate 29, Figs. 164, 166. 
164.

Little Crake

(Zapurritu parva).
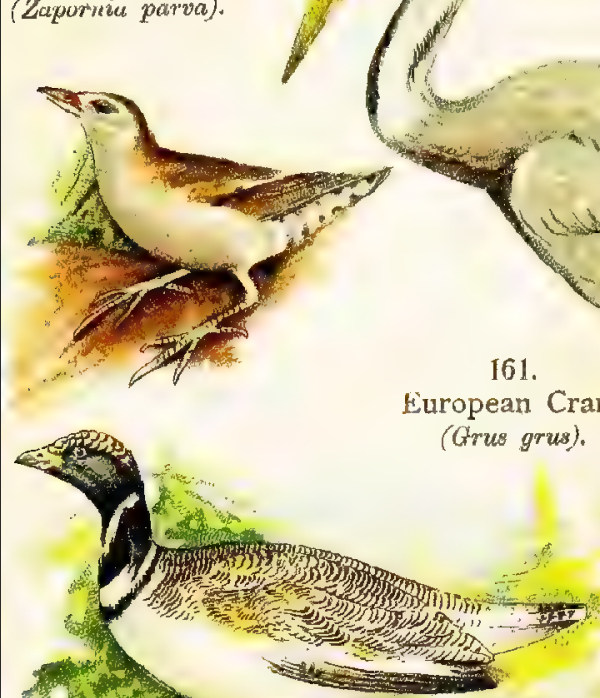

162.

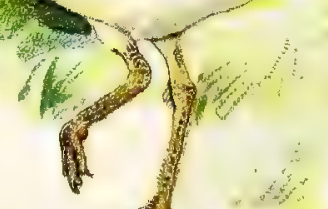

Little Bustard

(Tetrax tetrax).

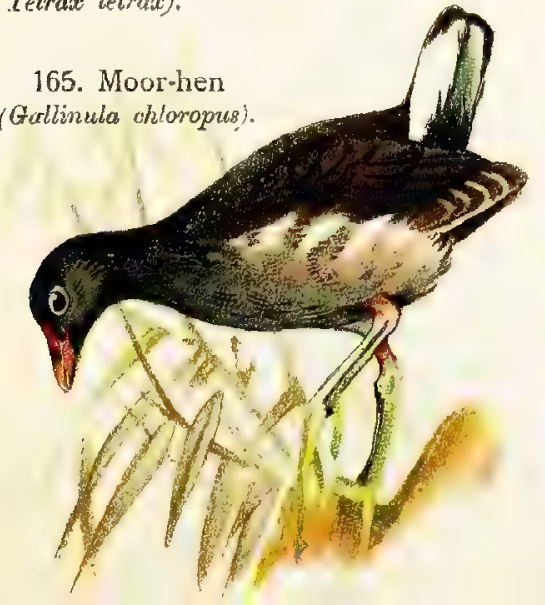

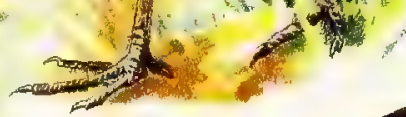

163. Water Rail (Ralhes aquaticurs).

161.
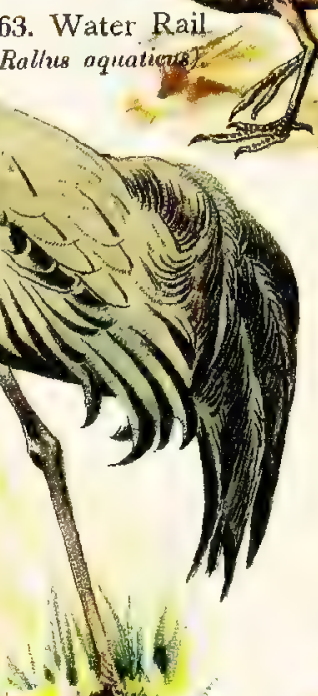
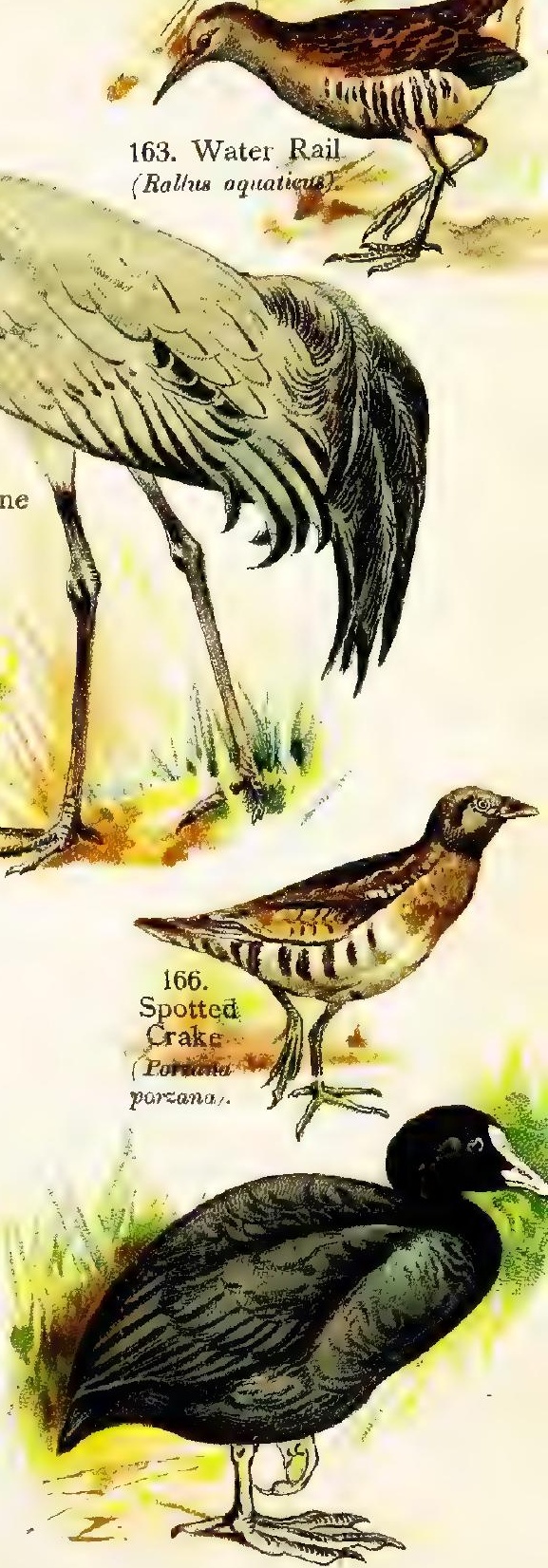

167. European Coot (Fulica atra). 

, 
A very near relative of the Spotted Crake is the Carolina Crake, or Sora, of this country, a pretty little bird of mottled plumage and black and white bars on the flanks.

The Corncrake, or Land Rail as it is often called, is common in Great Britain, but only occasionally seen in the eastern part of this country. Unlike the Little Crake and the Spotted Crake, which love the marshes, this bird frequents dry meadows, clover fields, and fields of corn. Though feeble in flight, when migrating this bird is able to travel many hundreds of miles without stopping, leaving the British Islands in the autumn to pass the winter in Africa, and returning in the spring. See Plate 30, Fig. 168.

This bird makes a remarkable creaking sound during the summer which can easily be imitated by passing the thumb-nail over the teeth of a fine comb. In this way they can often be lured into sight. Like the other Rails, the Corncrake does not take wing readily, and it flies slowly, with the legs hanging down. When captured, it sometimes tries to effect its escape by feigning death $-a$ device used by other members of this family also.

Some well-known species of Rail in this country are the King Rail, one of the largest forms, with variegated plumage of brown, black and grey above, reddish-brown below, and sides barred with white, found in the eastern parts of the United States; the 1 Virginia Rail, considerably smaller than the preceding, but resembling it in colour; the Clapper Rail, or Marsh Hen, with pale olive colouring above, greyishbrown on the wings, and, as with all the family, bars 
on the flanks; and the Little Black Rail, with rusty black plumage above, barred with white, nape of the neck reddish, and the under-parts slate colour.

The Gallinules constitute another branch of this family, two species of which are found in our Southern States. The Purple Gallinule has the head, neck, and breast a deep bluish-purple, the rest of the plumage shading to greenish, the under tail-coverts white. A distinguishing mark is the flat, waxy plate, red and blue in colour, on the top of the head. The bill is red, tipped with green, and the legs are yellow. In flying, the Purple Gallinule raises the short tail, displaying the pure white under-feathers, and the legs hang straight down. When a shot is fired, it is at once answered, like an echo, by hundreds of these birds. But, although heard, they are seldom seen, for their colouring harmonises so perfectly with the waterlily pads floating on the blue water that they are practically invisible. Their toes are very long and delicately made, enabling the birds to walk with ease over the vegetation of lakes and ponds in search of their food. They are also good swimmers.

The Florida Gallinule is about the same size as the preceding species, but differs in colouration, the back being brownish, the flanks streaked with white. The birds are often seen together in the fresh-water marshes of Florida, the more brilliant colouring of the first species mentioned making it easily distinguishable from the other.

The Water Rail is the commonest of European Rails. It is never found far from water, and, in spite of the fact that its feet are not webbed, it swims and 
240. Rufous Tinamou

(Rhynohotus rufescens).
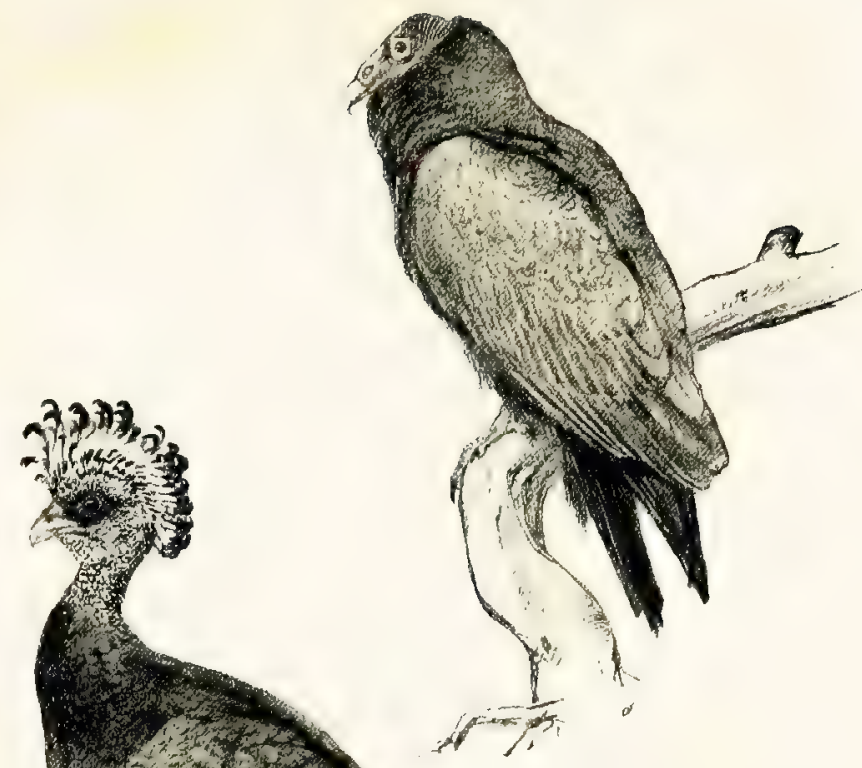

243. Turkey vulture

(Cathartes aura septentrionalis).

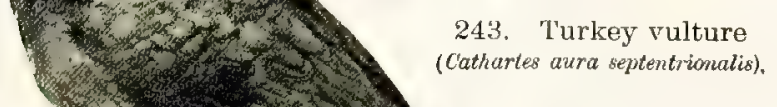

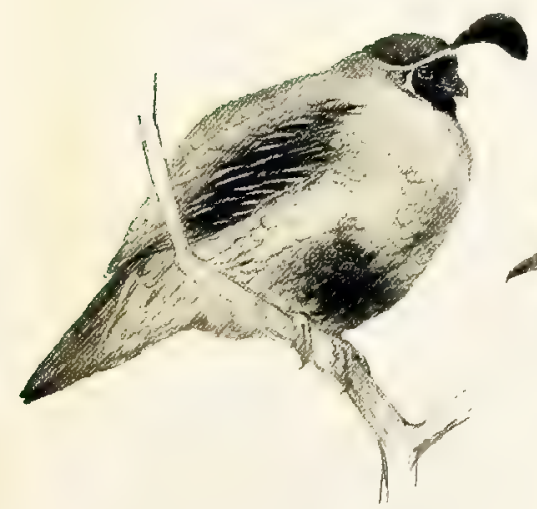

245. Gambel Partridge (Lophortwx gambellisis 

dives with remarkable ease. The toes are very long and slender. On account of its shy and retiring habits, this bird is rarely seen, even in localities where it is quite common. See Plate 29, Fig. 163.

The Coot and the Water Hen, or Common Gallinule, of Europe are also admirable divers. The toes of the Coot are provided with broad lobes along their sides.

The Moor Hen may be distinguished from the Coot not only by its smaller size, but also by the bright vermilion-red shield on the forehead and the white patches under the tail. Though an extremely timid bird in a wild state, it thrives well in captivity and is often seen in public collections. See Plate 29, Fig. 165.

The Coot is a larger bird than the Water Hen, or Gallinule, and is easily distinguished from it by the broad white bill. The European Coot has no white below the tail, and is also without the white markings on the wings that characterise the American species. Although very shy birds naturally, it is said that in certain localities in Florida where shooting is forbidden they are as tame as domestic Ducks. Young Coots, while still in the nestling plumage, have the head ornamented by numerous little fleshy warts of a bright red colour, while the rest of the body, as in the young of the Rail tribe generally, is jet black in colour. See Plate 29, Fig. 16\%.

The Little Bustard is common in certain parts of Europe, especially in the Spanish peninsula. It is abundant in Africa, north of the Sahara, also in northwestern India. See Plate 29, Fig. 162. 
The Great Bustard is known as the largest of European birds, male individuals often weighing as much as thirty pounds. It is now extinct in Great Britain, although at one time common there, but is still found on the Continent. The enclosures of waste land, planting of trees, and increase of population have driven it from many of its former breeding places. The males are much larger than the females and more brightly coloured; both sexes have long hair-like feathers back of the ears. During the breeding season the males go through with strange performances. The tail is thrown up over the back, showing the pure white under-tail coverts, the wings are drooped, and the bag, or pouch, which runs down the front of the neck, is inflated until it reaches enormous proportions, while the head is sunken between the shoulders, with the long ear-feathers standing up at the sides. See Plate 30, Fig. 169.

Bustards are confined exclusively to the Old World, most of the species being found in Africa. 


\section{CHAPTER IX}

\section{Plovers, Gulls, and Auks}

\section{ORDER - CHARADRIIFORMES}

$7 \mathrm{HE}$ birds which form the subject of the present chapter represent a varied assemblage, yet all are related. Besides the typical Plovers, they include the Pratincoles, Stilts, Curlews, Snipes, Phalaropes, Gulls, Terns, and Auks.

While some species frequent inland waters and marshy places, others keep more or less to the seacoast. Though the majority are never found far from water, some find a living on dry, sandy wastes. All are remarkable for their great powers of flight, some, indeed, travelling thousands of miles when migrating.

The young of the more typical of the Plover tribe are quite active from the moment they leave the shell, and are covered with short down more or less mottled with black; but the colouration of the down varies in different species, being very pale in those that breed in sandy wastes, and dark when the nesting-ground is in marshy places.

One of the most aberrant-that is, one that differs most from the typical form-is the beautiful Pratincole, or Glareola, a bird which in many ways resembles the Swallow. The tail is long and forked, the wings 
long and pointed, and the form is slender and graceful. The Pratincole breeds in many parts of the continent of Europe, but is only occasionally seen in the British Islands. Like the Swallow, it catches much of its food on the wing-beetles, grasshoppers and locusts forming the principal prey-and it runs very nimbly along the ground. This bird is in many of its characters unlike the true ?lovers, and is regarded as a descendant of a more ancient stock-as a side branch of the tree that gave rise to the typical Plovers. It has no representative in this country. See Plate 31, Fig. 175.

A good example of the true Plover is the Golden Plover, a bird widely distributed throughout both the Old World and the New, and known under many names. The American species is slightly smaller than the European, but resembles it in colouration. See Plate 30, Fig. 170.

In the breeding season this bird dons a gorgeous plumage, greyish above, thickly spotted with black, and all black below, but in the autumn the jet-black feathers of the under-parts become replaced by white, while the upper loses some of the black markings and becomes more golden in tone.

There are many species of Ringed Plover, the one figured being a common European and American shore-bird. This bird builds no nest, but deposits its eggs in a slight depression in the sand, and from their close resemblance to the surrounding stones, they are exceedingly difficult to locate. The nestlings are also very inconspicuous on the sand of the beach. See Plate 30, Fig. 173. 
One of the commonest of our Plovers is the Killdee, or Killdeer, so called from its notes, uttered loudly and rapidly when the bird is alarmed. It is greyish-brown above and white below, has a black band on the breast, and a black ring round the neck. Another distinguishing mark is a white line over the eye. The Killdeer resembles the preceding species, but is considerably larger. It feeds both by day and by night, on worms, beetles, grasshoppers, and so on, in marshes and, in winter, along the shore.

The Little Kentish Plover is a tiny bird, easily recognisable by its incomplete chest-band. It is common in many parts of Europe, but is somewhat rare in England, being met with most frequently in that country along the shingle beaches of Kent. See Plate 30, Fig. 174.

The Piping Plover is a small form found in eastern North America, ashy-brown above and white below.

The Lapwing, or Peewit, is another bird of this tribe that is common in Europe, especially so in England, where its eggs are highly esteemed for food, many of them being sold in the markets of London under the name of Plovers' eggs-a practice that must result in reducing its numbers. See Plate 30, Fig. 171.

The male bird is very beautiful in colour, iridescent green and purple, under-parts white, the long crest and top of the head black and the feet red.

The eggs of the Lapwing vary greatly in colour. They are laid in slight hollows in the ground, little or no nest being made for their reception. On the approach of winter these birds collect in large flocks, dis- 
persing again in the spring. They are among the most valuable of the farmer's allies, worms, slugs and insects forming their principal food.

The Black-winged Stilt is one of the most remarkable of the Plover tribe, having extremely long legs (from which fact it receives its name), a long, sharp bill, long neck and long wings. The colour, in general, is blackish above and white below, and the feet and legs are brilliant red. This bird is met with abundantly in marshy places in the Old World. The great length of the Stilt's legs is due to the fact that the bird obtains its food by wading in shallow water and probing in the mud for snails and other small creatures. See Plate 30, Fig. 172.

Occasionally seen in the eastern parts of this country, and quite common in certain sections of the West, is the Black-necked Stilt, which is all black above and white below.

The Avocet is one of the strangest forms of Plover, having a very long, slender, upward-curving bill, long legs and webbed toes, in the latter respect differing from most of the Wading-birds, whose toes are free. The colour of the Avocet is chiefly black and white and the legs are bluish. The principal American species differs from the European in having a reddish-brown head and neck. See Plate 32, Fig. 184.

The Snipe and the Woodcock are birds with which most people are somewhat $f_{\text {amiliar. }}$ The long, slender bills and long legs which gistinguish them show at once that they cannot live longfar away from water. They are, indeed, dwellers in marshes and swamps, living on worms and aquatic insects and small water-snails. 


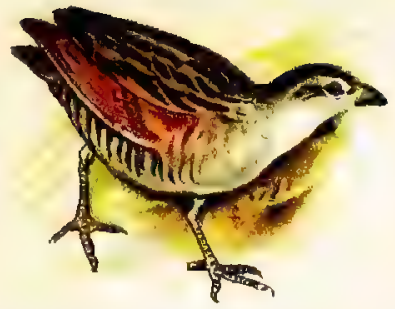

168. Corn Crake (Crex crex).
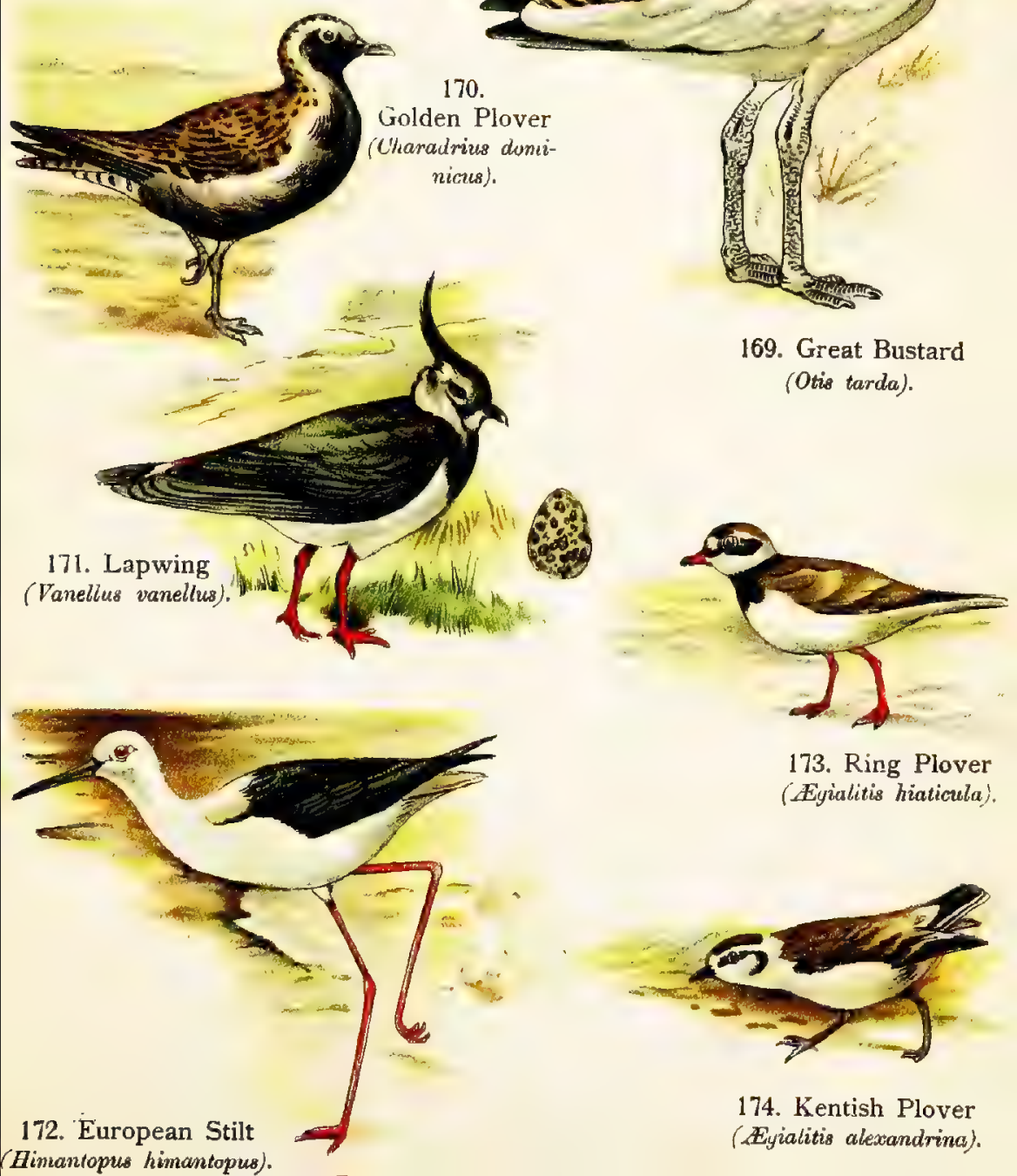

173. Ring Plover (Eyialitis hiaticula).

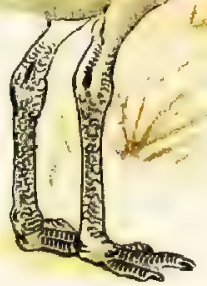

169. Great Bustard (Otis tarda).

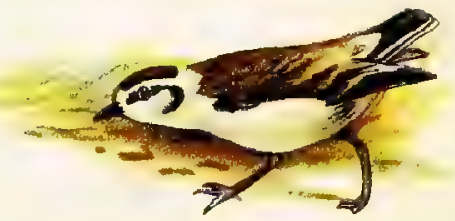

174. Kentish Plover (Eyialitis alexandrina). 

The worms are obtained by probing in the soft soil and are apparently detected by the tip of the beak, which is supplied with a pair of large nerves and is therefore extremely sensitive.

The buff and black stripings and barrings on these birds play a very important part, since they serve to blend the body with the surrounding grasses when the bird is crouching to avoid its enemies. This it always does in preference to seeking safety by flight.

In the spring both males and females spend much of their time in making extraordinary sounds known as "bleating." This curious, humming noise they produce by mounting high in the air and then descending with tremendous rapidity, meanwhile spreading the wings so that the two outer feathers stand apart from the rest. The rush of air against these is now known to cause the sounds which have puzzled so many observers.

The Common Snipe of Europe has fourteen tailfeathers, while the nearly related American species has sixteen. See Plate 31, Fig. 178.

The Jack Snipe is a common British bird during the winter season, leaving in the spring to breed in northern Europe. Smaller than the Common Snipe, it is further distinguished from it by having but twelve tail-feathers. This bird also makes curious noises during the breeding season, but these are apparently vocal and not made by the wing-feathers. It is said that this noise resembles that made by a horse when galloping on a hard road.

The real home of the Great, or Solitary, Snipe is in the marshy districts of Poland and in parts of Russia, 
but it is met with also in Africa and in Asia. It is a larger bird than the Common English Snipe, has relatively shorter beak and legs and more closely barred under-parts. See Plate 31, Fig. 179.

The Willet is a common North American bird of the Snipe family, with black-lined wings and otherwise varied plumage. It is rather large, has a heavier bill than most of the Snipes, and bluish feet.

A well-known marsh bird of this country is the Yellowlegs, named from its conspicuously bright yellow legs. This and the preceding species are members of a group called Tattlers, from their habit of giving shrill cries on the approach of sportsmen. Their flesh is highly prized for the table. These birds are found in summer throughout the temperate parts of North America, migrating in winter to Central and South America. Their plumage is, in general, a mixture of black and white, in spots and streaks. They are semipalmated, or partly webbed, and can swim, fly and run with equal facility. The Greater Yellowlegs and the Lesser Yellowlegs are similar in colouring, but the second is considerably smaller than the first named and has relatively longer legs.

The Woodcock is found in both the Old World and the New and differs but little in colour. The European species is much larger than the American and has the breast barred, while that of our bird is wholecoloured. The plumage is a beautiful mixture of russet-brown and black and there is a transverse black bar across the top of the head. The Woodcock is closely allied to the true Snipe, having the long, straight, sensitive bill common to that family, the 
upper mandible being used much as a finger when probing in the mud for worms and larvæ.

The European Woodcock is occasionally seen on our shores as a straggler. In both countries the flesh of this bird is so highly esteemed for the table that it is in danger of extermination. It breeds chiefly in the higher latitudes, laying its eggs upon the ground in the woods, in nests of leaves. See Plate 31, Fig. $17 \%$.

A curious anatomical character in the Woodcock is the position of the ear opening, which is in front of and beneath the level of the eye. In the Snipe it lies underneath the eye, while in all other birds it is found behind the eye. The eyes of this bird are large, dark brown in colour and set far at the back of the head and close to the top.

The Woodcock is nocturnal in habits, starting for its feeding-grounds in the early evening. It makes remarkable spiral flights high up into the air, during which the wind rushes through the stiff outer primaries with a whistling or bleating sound.

The species now to be described differ conspicuously from the Snipes and Woodcocks in that they have two distinct plumages during the year-a sober-coloured dress for autumn and winter and a more richly coloured one for spring and summer. The latter being assumed just before the nesting season, is known as the breeding dress.

This difference is not very strikingly marked in the Greenshank, a somewhat common European bird, so called from the colour of its legs. It is rather large, measuring about fourteen inches in length, and has a slightly upturned bill. In summer the upper parts 
of the neck and wings are nearly black, relieved by pale grey edgings to the feathers; the lower parts are flecked with ashy brown. In winter the upper parts are greyer and the under parts white. See Plate 81, Fig. 180.

The eggs of the Greenshank are a warm stone colour, blotched with purplish-grey and spots of brown. The nest, such as it is, is often placed at a distance from water and sometimes on dry ground amid scattered pine trees.

In our country this bird is represented by the Godwits, or Marlins, found on the Pacific coast and also in the interior of the Western States, but seldom on the Atlantic coast. In colouring and in general characters they resemble the species figured.

In the Dunlin the contrast between the summer and winter plumages is very striking. In winter the upper parts are ash-coloured, the under parts white; but towards the end of March the new livery begins to make its appearance. When complete the upper parts are a rich golden-brown, streaked and blotched with black, except the wings, which remain grey, while the breast becomes jet black. The females are somewhat larger and have longer beaks than the males, but in the length of beak there is great variation in both sexes.

The Dunlin, like the Snipe and Woodcock and many other long and slender-beaked waders, has the power of curving the tip of the upper mandible upwards for a considerable distance, enabling it to seize its prey when the beak is thrust downward into the mud of their feeding-grounds. See Plate 32, Fig. 185. 


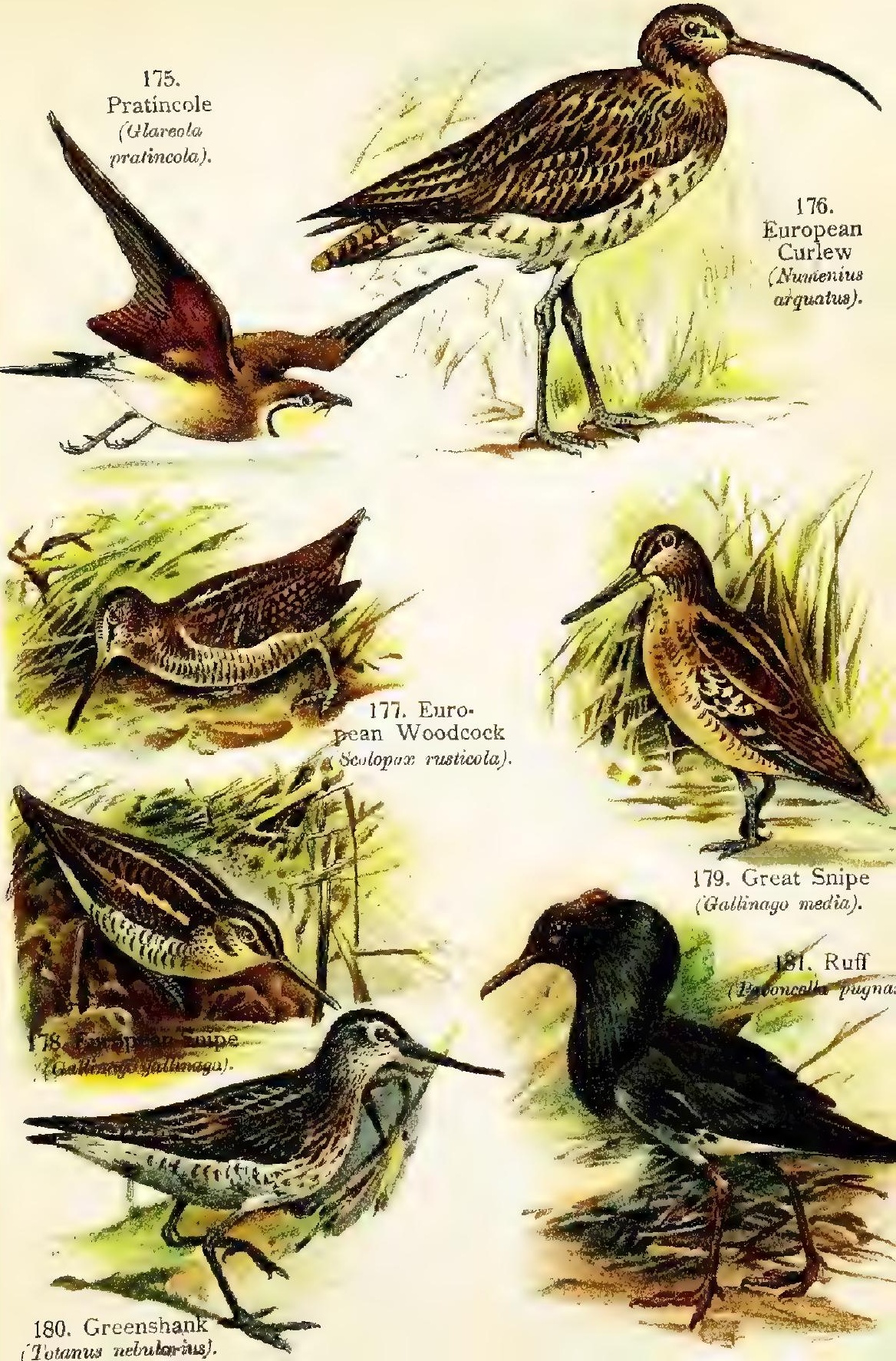




$$
-
$$


This bird is widely distributed throughout the northern hemisphere, migrating at the beginning of winter to a warmer climate. It breeds chiefly in the Arctic regions. The variety found in this country is slightly larger than that of the Old World and has a longer bill, slightly recurved.

In its winter dress the Little Stint looks like a miniature Dunlin, but in summer it assumes the colouration of its larger relative only so far as the upper parts are concerned, the under parts remaining white. Its breeding-ground is in the northern hemisphere, but it takes long journeys when migrating, and in the winter is found in many parts of the world. See Plate 32, Fig. 183.

Our American Stint is commonly called the Least Sandpiper and differs from the European species chiefly in that it is smaller and darker in colour at all seasons. This tiny wanderer, but six inches in length, sometimes strays as far as Great Britain and other parts of Europe. Its bill is straight. A larger species, the Semipalmated Sandpiper, is sometimes seen with the Least Sandpiper along our coasts.

Many other species of Sandpiper are found in this country.

The Curlew Sandpiper, which is only an occasional visitor to the United 'States, is very striking in the matter of plumage. In winter ash grey above and white below, this bird in the early spring assumes a richly coloured livery, the upper parts being beautifully barred and streaked with black and grey on a ground of rich chestnut, while the under parts are reddish, slightly barred on the flanks with dark brown and 
grey. The females, as in the Plovers generally, resemble the males and are slightly larger. See Plate 32, Fig. 186.

In the autumn these birds visit the eastern shores of Great Britain in great numbers, the immigration at that time consisting chiefly of young birds. Smaller numbers of adult birds arrive in the spring in their full breeding colours, on their way to their breeding-grounds within the Arctic Circle.

Like the Curlew Sandpiper, the Knot and the Sanderling have a red breeding plumage.

The Knot, also called Robin Snipe and Grey Snipe, is the largest of these three species, measuring ten inches in length. In winter grey above and white below, it assumes in the spring a very handsome dress. The head and neck are reddish-brown, with dark streaks, the back-feathers are blackish, spotted with chestnut and margined with white, while the throat and breast are a rich dark chestnut. See Plate 32, Fig. 187.

Until the year $18 \% 6$ the breeding-place of the Knot was unknown. It was then discovered nesting in the snow of the Arctic regions, by Colonel Fielding, when on an Arctic expedition. On this occasion nestlings only were found, and the eggs were unknown until the year 1901, when specimens were found in the Taimyr Peninsula, Siberia.

The Knot is well known in this country along the Atlantic seaboard, as well as on the Great Lakes and in the Mississippi Valley.

The Sanderling differs from the other Sandpipers in that it lacks the hind-toe. In its autumn and win- 
ter dress this bird is grey above and white below, but during the summer months the feathers of the upper parts have dark brown or black centres, edged or spotted with rufous, while the face, neck and upper part of the breast are a pale chestnut, spotted with dark brown. This little bird breeds in the far north, but at other times is found along the beaches in almost every part of the world. See Plate 32, Fig. 188.

In many ways the most remarkable of the Plover tribe is the Ruff, sometimes called the Fighting Sandpiper, a bird that is widely distributed in the Old World, though but rarely seen in America. The male takes its name from a wonderful frill of feathers about the neck, bearing a fancied resemblance to the Elizabethan ruff. The female is called a Reeve, but for what reason is not known. The colouration of the ruff varies in every individual. As if still further to heighten the effect of this ornament, the head is adorned with broad ear-tufts, while around the beak are brilliantly coloured, fleshy tubercles. In the illustration the ruff is black and the ear-tufts dark brown, but ruffs of white, buff and chestnut also occur, and they may be plain, banded, spotted or streaked with darker colours. In the autumn the various ornaments are discarded, and the male is distinguished from the female only by its larger size. These ruffs are made to play an important part during the courting season, for at this time their wearers meet together daily for the purpose of sparring with each other and fighting mimic battles. When a Ruff is in the presence of a Reeve he behaves very strangely, thrusting his beak 
down to the ground and spreading out his ruff and ear-tufts to the fullest extent. And in this position he will stand for a minute or more, as if to give the female time to admire him, though, as often as not, she quietly walks off as soon as she sees that he is too absorbed in his ceremonial to notice whether she is looking or not. See Plate 31, Fig. 181.

The Redshank brings us back to the more normal Wading-birds. The name is derived from the orange colour of the legs. This bird is common in many parts of the Old World, but is not known in America. Although it has distinct summer and winter plumage, these do not differ conspicuously. The lower part of the back is always white. See Plate 32, Fig. 182.

The American Oyster-catcher is a strictly marine bird of this tribe, so called from its habit of feeding upon small oysters, clams and other mollusks found along beaches, using its strong beak to force open the shells. It breeds on the coast as far north as southern New Jersey and is fairly common. Three species are found in America, the Black Oyster-catcher having entirely black plumage, with red bill, feet and eyes.

Several species of Curlew are native to this country, the largest of which is the Long-billed, found chiefly in the interior as far north as Manitoba, but also seen along the coast. The beak is long and curved like that of an Ibis. The colouration is black and buff above, the tail barred with the same colours, the under parts buff, streaked with darker colour. This is the largest of American shore-birds, measuring about two feet in length, the long, pointed wings spreading about forty 

inches. Like that of the Snipe and Woodcock, this plumage is worn throughout the year.

A commoner species along our coasts is the Hudsonian Curlew, a smaller form than the preceding. The Eskimo Curlew is more frequently met with in the interior, being more of a field bird than either of the others mentioned.

The species figured is the European Curlew, which closely resembles the American. See Plate 31, Fig. 176.

The Phalaropes are small birds, in general appearance resembling the Sandpipers, but having lobed toes. The wings are long and the tail rather short. They breed in the Arctic regions and migrate southward in winter.

The largest and most beautiful species is Wilson's Phalarope, found only in America, chiefly in the interior of the country. The female exceeds the male in size and beauty, and he performs the duties of nestbuilding and brooding the eggs. The plumage is ashcolour above, varied with chestnut, and white below; the bill and feet are black.

The Jacanas are related to the Plover tribe and are found in both America and Europe. These are small birds, having enormously long toes and claws that enable them to walk with ease over floating aquatic plants. The commonest species in this country is the Mexican Jacana. The tail is short and the wings are provided with spurs that are used in fighting, the birds being very quarrelsome. They are found along the banks of streams and ponds, but are unable to swim. 


\section{GULLS}

At one time regarded as near relatives of the Petrels, it is now known that these birds are much more closely related to the Plovers, and this relationship is shown, curiously enough, most strikingly in the colouration of the eggs on the one hand and in the skeleton on the other, though many other common anatomical characters afford equally positive evidence of this fact.

Like the Petrels and unlike the Plovers, they are web-footed. But they differ from the Petrels and resemble the Plovers in having slit-like instead of tubular nostrils.

Such species as display a distinct summer dress have this change confined to the colouration of the head. Many species require several years to attain their fully adult plumage.

Gulls fly with more deliberate flaps of the wings than Terns and Jaegers and are able to keep in the air even longer without coming to the water to rest. It is believed that individuals have followed vessels entirely across the Atlantic. Gulls are excellent swimmers, exceedingly buoyant and floating high on the waves with the breast seeming just to touch. One alighting upon the water is a very pretty sight, indeed. Raising the wings high above the back as it nears the surface, with the delicate feet extended downward, the bird settles quietly to rest, folding its wings and carefully adjusting its plumage. They sleep or appear to sleep in the wildest sea, bobbing up and down on the waves like corks, and no amount of spray 
or wind seems to affect them. Strangely enough, they are able to accelerate their speed without flapping the wings, and a Gull hovering at the stern of a swiftly moving steamer will suddenly fly ahead of and around it, resuming its position at the stern without a single wing-beat. Gulls fly by night as well as by day and take very little, if any, sleep, for days at a time, resting on the water for some hours and then resuming their flight.

Gulls have long and rather narrow wings, particularly adapted for long-continued and powerful flight. They flap the wings apparently with considerable effort, but in spite of seeming exhaustion keep flapping for hours at a time on inland streams or rivers where the wind is hardly sufficient to buoy them up.

All have powerful bills which serve in tearing their food. The legs are short and delicate, the feet small and webbed. Most species are white mixed with grey or black, though in one or two forms a reddish tint is visible on the feathers. The plumage is exquisitely soft and smooth and always in immaculate condition.

Gulls nest in many different sites, but usually on the ground, either among rocks or on the sandy shores. Occasionally they build in trees. They eat a great variety of food and are practically birds of prey, feeding on small animals and the eggs and young of other birds. This is particularly true of the Jaegers, who keep the Murres, Puffins and Auks which nest in the same localities constantly on the alert to protect their nurseries from these marauders.

The voice of the Gull is peculiarly harsh, and the 
screams of these birds above a heavy storm are frequently heard on vessels far out at sea.

The young are covered with a fluffy down, usually mottled with grey, light brown and white. They remain in the nest for a considerable time and are so protectively coloured that they are with difficulty distinguished from their surroundings.

Besides living food, Gulls consume an immense amount of refuse matter found along shore in the neighbourhood of cities. For some years scows laden with refuse from the city of New York have, at regular intervals, emptied their contents some miles out at sea. At the shriek of the whistle on one of these barges - the signal to dump the garbage into the seathey begin to gather in thousands to feed upon it, and those who have seen it say it is a most remarkable spectacle to see these birds hurrying from all quarters to the feast.

Great numbers of Gulls were formerly killed by feather hunters, but fortunately they are now protected, and they have again become quite plentiful along our coasts.

The Herring Gull affords a good instance of the Gulls which take several years to attain the characteristic adult dress. The back in this species is a delicate grey, the rest of the plumage pure white, set off by the yellow colour of the feet and beak. The beak is further decorated by a touch of bright red. The eye is a beautiful straw colour, set in a frame of vermilion formed by the rim of the eyelid. The sexes cannot be distinguished externally, and the summer and winter plumage is alike, except that in winter the head is 


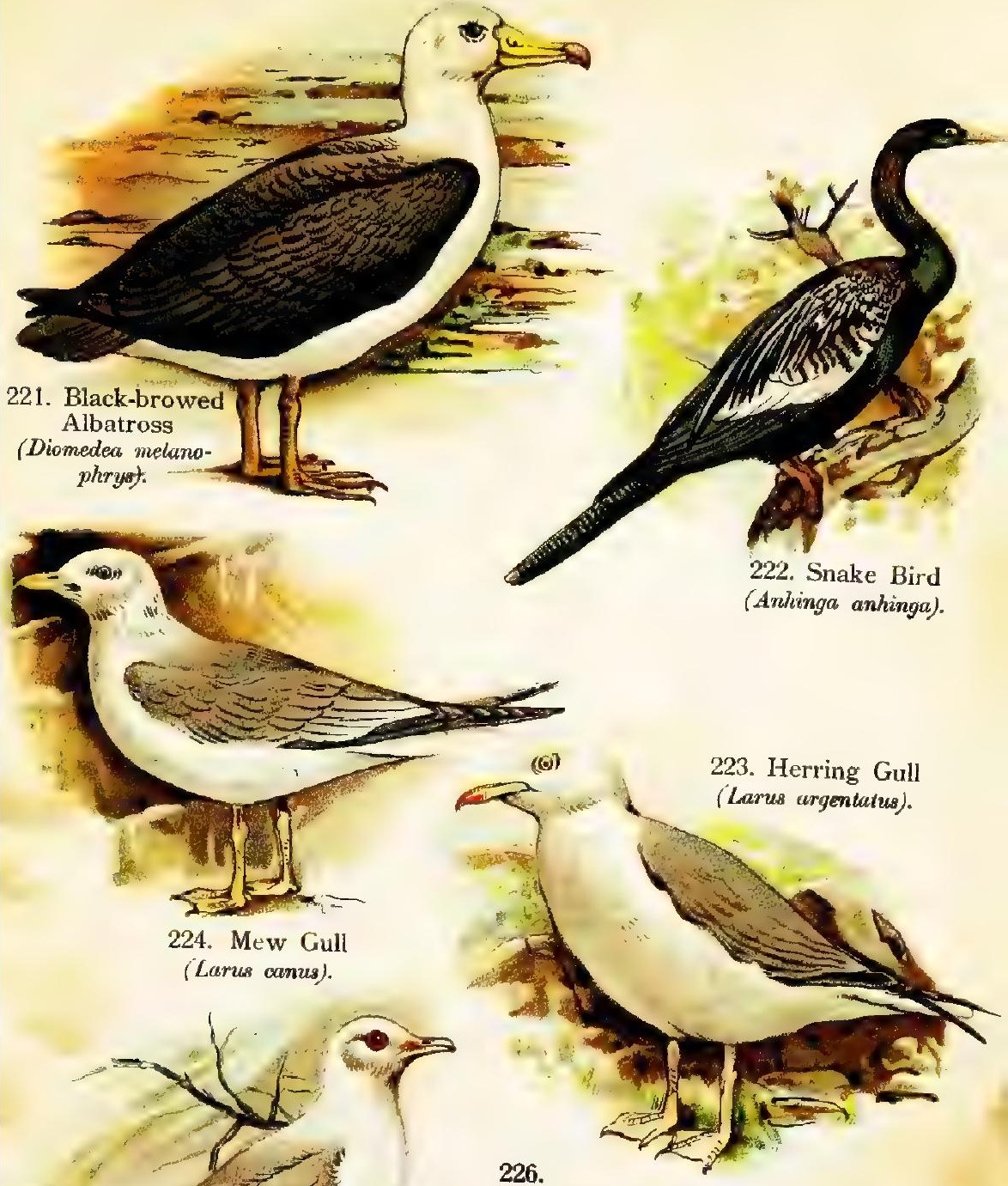

Parasitic Jaegel (Stercorarius parasiticus).

225. Kittiwake (Risea tridactyla).

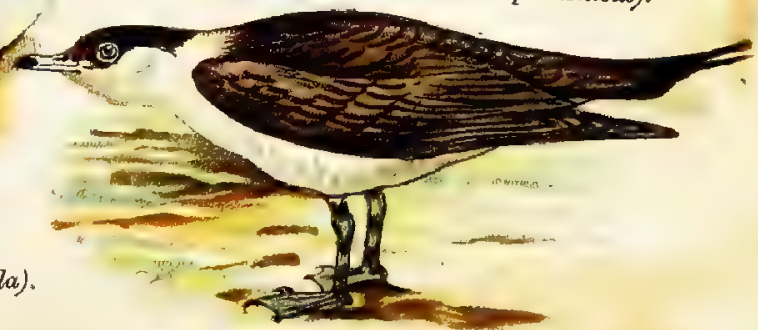



streaked with grey. The young birds are mottled with brown. See Plate 38, Fig. 223.

The Herring Gull is common in both Europe and America and the two forms are practically alike in size and colour. This is the bird so commonly seen in our harbours and following in the track of vessels.

Nearly allied to the Herring Gull is the Great Black-backed Gull, a rather larger bird than the former and distinguished from it by having a dark, slaty black instead of pale grey back. The tips of the wings and rest of the plumage are pure white. It is a more northern species than the Herring Gull, but is frequently seen in company with them.

The Common European Gull, or Mew Gull, as it is called in Great Britain, and the Kittiwake, have no decided difference of plumage, except that in winter the head and upper part of the neck become flecked with grey, as in the Herring Gull. In the Kittiwake the hind-toe has become reduced to the vanishing point. See Plate 38, Figs. 224, 225.

There are several species of these birds in this country, but they differ little in general appearance.

The Black-headed Gull differs from those just described in that during the summer months the head assumes a dark brown colour, which, when the bird is. flying, looks black; hence its name. Young birds in their first plumage may be readily distinguished by the fact that the small feathers of the wings are brown, while the tail has a black bar across the tip. But the fully adult characters are assumed on the completion of the first year-in which it differs from the 
Herring and Black-backed Gulls, which require years to attain the adult plumage. See Plate 39, Fig. 228.

During the winter months, for some years past, these birds have assembled in large numbers on the Thames and on the waters of the London parks.

The Laughing Gull, which breeds in the eastern part of North America, has in summer dark grey wings and back, with black primaries, head and throat darker, under parts white, and bill a deep red; in winter, the head and throat become white, sometimes streaked with greyish colour. The name is taken from its curious cry, resembling laughter.

The Black Skimmer or Scissor-bill is a remarkable member of the Gull family, having the lower mandible considerably longer than the upper. Both are thin and very flexible, and the bird skims the surface of the water in search of small aquatic creatures. These birds are quite common along our southern coasts, nesting in the sand and gravel of the beach. The young harmonise so perfectly with their surroundings as to be practically invisible. In them for some time the mandibles are of equal length. The plumage of the adult bird is black and white and the bill is red and black.

The small, fork-tailed, short-legged birds known as Terns are very closely related to the Gulls, but have relatively longer wings and are much more graceful and swift in flight. They perform many strange evolutions in the air, large flocks flying round and round in a huge circle, wheeling and swerving like one bird. They are extremely noisy, uttering their harsh calls almost continuously. Terns flap their wings much. 
oftener than Gulls and may readily be distinguished from them by their smaller size and long, sharply pointed bilis. They are not as good swimmers, having very small and delicate feet. On shore they patter about in a very pretty and graceful manner. Their food consists principally of living fish, which they procure by diving from a considerable height into the water.

Their nesting habits are similar to those of Gulls, great colonies of them laying their eggs in hollows on the beach, usually on remote islands, but sometimes on the coast or along inland waters. Great numbers of the Common, or Wilson's, Tern breed on the island of Penikese, off the coast of Massachusetts, a favourable site for them, since it has in recent years become Government property and the breeding-grounds of the birds will be protected. The young are tiny, fluffy creatures, much like young Gulls for the first few months of their existence, and bear a close resemblance to their surroundings. See Plate 39, Fig. 230.

The Royal Tern is frequently seen along our southern coasts, particularly in Florida, where it is often seen.chasing the less active Pelicans and forcing them to disgorge their prey, when by a swift plunge they secure the prize before it reaches the water. Another interesting species is the Noddy Tern, found in summer along the Gulf coast. In this the top of the head is white, instead of black, the rest of the plumage a very dark brown and the middle tail-feathers are longest. In Terns the outer tail-feathers are longer than the others, as in Swallows, and hence they are often 
called Sea Swallows. When alarmed, these birds hover distractedly in the air above their nests.

The Little, or Least, Tern in its general appearance resembles the Common Tern, from which, however, it may be readily distinguished by its much smaller size and by the yellow, black-tipped beak. The Least Tern of America is nearly related to the European species, but has less black on the back. It is said to vary its fish diet with insects. As may be inferred from its name, this is the smallest member of the Tern family. See Plate 39, Fig. $22 \%$.

The Bridled and Sooty Terns are two species that closely resemble each other, found in tropical and subtropical regions of the western hemisphere.

The Fulmar is remarkable for having two distinct phases of plumage - a light phase, in which the head, neck and under parts are white, with back, wings and tail grey, and a dark phase, in which the whole plumage is much the same shade of dark, smoky grey. This bird is Gull-like in form, but has longer wings. These are occasionally flapped slowly in flight, but much of the time are held stiffly outstretched.

The Sandwich Tern derives its name from the place where it was first observed-Sandwich, England. In this species the crown in summer is black and the beak is black tipped with yellow. The back, as in the other Terns and many of the Gulls, is a beautiful pearlgrey, the under-parts white, but tinged with a salmonpink colour, which rapidly fades after the death of the bird. The legs and feet are black, in this respect differing from those of the other Terns described. See Plate 39, Fig. 229. 
Skuas and Jaegers are Gull-like birds found along the waters of the northern hemisphere. They differ from typical Gulls and Terns not only anatomically and in their more sombre colouration, but also in their habits. They are known as parasitic, from the fact that they chase Gulls and force them to disgorge the fish they have captured. So expert is the Skua that he will catch the fish dropped by his victim before it can reach the sea. Skuas also devour the eggs and young of any other birds which may have the misfortune to be breeding in their neighbourhood.

The nestlings of the various species of Skuas differ from those of Gulls and Terns in being dark and whole-coloured, instead of grey and mottled with black.

The Parasitic Jaeger and the Long-tailed Jaeger, as it is often called, are found the whole way round the northern hemisphere, having a wide range over the Arctic regions of America. See Plate 38, Fig. 226.

\section{Auks}

The Auks - in other words, the Guillemots, Razorbills and Puffins-are among the most interesting of living birds, for there can be little doubt that they are descended from some Plover-like ancestor and that their present peculiarities of shape and structure were slowly acquired as they became more and more aquatic until they have assumed a close resemblance to the far more ancient Diving-birds. As divers and in the skill they display in the capture of fish, which they chase under water, these birds have no rivals. They are never met with in fresh water, but frequent rocky 
coasts in the northern parts of both hemispheres, where they live in enormous colonies.

The Guillemot and the Razor-bill breed on the edges of cliffs, laying, on the bare rock, but a single pear-shaped egg. The Puffin, on the other hand, chooses a burrow for its nest, seizing, as a rule, one dug either by a rabbit or a Petrel, and driving out the rightful occupants by the aid of its powerful beak. See Plate 40, Fig. 239.

These birds are all compact in form, with short, rounded tails and webbed feet. Their wings, while short, are very powerful, and the birds fly with great speed, but they are not graceful on the wing and do not soar like the Gulls and some of their allies. Owing to their almost inaccessible breeding-grounds, these birds are still very plentiful. Their eggs are used for food by the Eskimos and the flesh of the birds as well. The eggs are collected during the warmer months of the year and stored for use during the long winter. See Plate 39, Fig. 233.

The Murres are closely allied to the Guillemots and much like them in form. Two species-the California and Pallas's Murre-are extremely abundant on the islands of the Bering Sea and are said "to outnumber all the other sea birds in that region fully ten to one." See Plate 40, Fig. 238.

One writer who has studied these birds in their haunts on the islands of the Bering Sea, says: "Puffins are the most outlandish birds, trim in build, about a foot in length, with very short feet and webbed toes. When seated on the rocks they assume an erect posture, and their small heads set close down upon their 
shoulders look ridiculously insignificant in comparison with their exaggerated beaks, which are much flattened sidewise and immensely spread out from top to bottom. . . . This great beak is largely an appendage of the breeding season and is cast, like the antlers of a deer, at the end of that period." It is brilliantly coloured in red, yellow and green.

In the Tufted Puffin, during the breeding season, two bunches of yellow feathers grow from the sides of the head just behind the eye, extending for some distance behind the neck. It is brownish-black above and greyish-brown below, while the Horned Puffin, which takes its name from a small excrescence on the eyelid, is almost black above and white below, and the feet are brilliant red.

The Great Auk, a larger bird than any of the preceding species, standing more than two feet in height, has become extinct since the middle of the last century. Its wings were rudimentary, and being unable to fly it was quickly killed off by early travellers to the North for its feathers, flesh and oil, and a few skins, bones and eggs that have been preserved in museums and by collectors are all that remain of this interesting bird. In colouring, the Great Auk was all black above and pure white below, with a large white spot in front of the eyes.

The $W$ ings of the Little Auk, or Dovekie fortunately unlike those of its great relative, are well developed and used in flight. This bird is common along the rocky shores of the British Islands and many other favourable localities in the north Atlantic. See Plate 40, Fig. 236. 


\section{CHAPTER X}

\section{Pigeons \\ ORDER-COLUMB円}

$\mathbf{P}^{\mathrm{T}}$

IGEONS are now generally believed to be very near relations of the Plover tribe, little as these two groups appear to have in common, judged by external characters alone. When, however, we compare them anatomically, we gain true insight into their relationships.

Pigeons are, for the most part, short-legged, arboreal birds. Certain forms, however, such as the Crowned Pigeons and a few others, have taken to living on the ground, and in these the legs are much longer than in the tree-living species.

Two white eggs are laid in a season and the parents relieve each other in the task of incubating. The young are hatched naked and are for a long time helpless. Pigeons are remarkable from the fact that the inner walls of the crop, which is of great size, are richly provided with blood-vessels which during the breeding season secrete what is known as "Pigeon's milk," and on this the young are fed, the parent thrusting its bill into the mouth of the young and regurgitating this substance.

The Pigeon family is a very large one, consisting of 
about three hundred species, and is distributed over a large part of the warmer sections of the world. A great many are found in the East Indies, especially in the Malayan Archipelago. In form they resemble each other closely. They are, as a rule, fairly large birds, with strong feet and legs, and in walking have a singular jerky motion, the head bobbing backwards and forwards at each step. When rising from the ground, many beat the backs of their wings together, causing a loud flapping sound. The different domestic breeds are supposed to be descendants of the Rock Dove of Europe. The young are known as squabs, and are highly prized for food.

Pigeons, as a rule, are gregarious, flying in large flocks, although some species are solitary in habits. In flight they do not seem to have any orderly arrangement like that of Ducks and Geese, but proceed in a compact mass.

The attitude of Pigeons in perching is peculiar and very characteristic. The feet-that is, the portion from the toes to the heel-are placed in an almost horizontal position, the bird appearing to hang away from the branch or perch in an awkward manner. The grasping power of the toes must be considerable in order to maintain this position. Most birds perch with the feet directly under the body.

The voice of Pigeons is a well-marked character, best described by the word "coo," which perhaps most closely resembles it. The sound is always accompanied by the curious bobbing motion of the head.

As a rule, Pigeons of the western hemisphere resemble each other somewhat in colouring, which is 
a fawn or greyish, variously mingled with spots of black and white. Nearly all have a slight iridescence about the neck and head and sometimes on the wings. A few species have long, sharp-pointed tails like that of the Passenger Pigeon and Mourning Dove, but most of them have short, square tails.

The remarkable extinct bird known as the Dodo was long a puzzle to scientific men, but is now known to have belonged to the Pigeon tribe. It was an inhabitant of Mauritius and was discovered by the early sea captains who visited the island in search of water. The Dodo was as heavy or heavier than the Turkeycock and round and ungainly in appearance. The head was enormously large, the bill long and sharply recurved. It was absolutely flightless, the wings being represented by a few small, fluffy, Ostrich-like plumes. The legs were short and stout, the feet heavy and armed with powerful claws. Being flightless and clumsy and so unable to escape from their enemies, these birds were very quickly exterminated, only a few scattered bones and feathers now carefully preserved in museums remaining of this gigantic Pigeon.

The American Passenger Pigeon was remarkable for the enormous numbers in which it existed in the United States not more than fifty years ago. These birds literally swarmed over the country. A flock seen by the naturalist Wilson was estimated by him to consist of many millions, and in $\mathbf{1 8 1 3}$ Audubon reported enormous hosts of them, so thickly packed that they obscured the light of the sun at noontime as effectively as an eclipse. See Plate 22, Fig. 133.

Another naturalist, Brewster, describing the nest- 

ing-place of these birds in Michigan so recently as 1866, says: "The birds arrived in two separate bodies, the largest of which formed a compact mass of Pigeons at least five miles long by one mile wide. The nesting area extended for a distance of eight miles through hardwood timber, then crossed a river, . . . and thence stretched through pinewoods about twenty miles."

These birds were subjected to merciless persecution, being shot by thousands and the flesh of the young used for food. They became enormously fat and were sometimes killed merely for the oil that was extracted from the fat. It is not easy to understand, however, why the Passenger Pigeon should have become completely exterminated in so short a time, as it would seem that a few straggling flocks or individuals might still be in existence. But although the entire country has been searched again and again by expert naturalists in search of these birds, none have been discovered in recent years, those purporting to be of this species usually proving to be specimens of the Mourning Dove or Zenaida.

There are many species of Turtle Doves, all inhabitants of the Old World. The one figured is frequently seen in collections. It is quite abundant in certain parts of the British Islands during the summer months. Another species commonly seen in captivity is cream-coloured. These birds are popularly supposed to have a strong affection for each other, probably from their habit of nestling close together when perching. As a matter of fact, Pigeons in general are rather quarrelsome and disagreèable toward each 
other, the males in particular pecking at and annoying the females. See Plate 23, Fig. 137.

The Ring, or Barbary Dove is a near relative of the Turtle Dove and is met with from Constantinople to India. The so-called "Turtle Dove," so commonly kept in cages, is really the Barbary Dove, though the domesticated birds now form a race apart from the wild species. See Plate 22, Fig. 130.

The Fruit Pigeons of the Old World constitute a very large family, divided into many sub-families. They are of considerable size, and, as their common name implies, feed almost exclusively upon fruit. It is quite probable, however, that they also feed upon seeds, roots and insects.

The Nicobar Pigeon is an East Indian species, chiefly remarkable for the long, pointed, iridescent feathers growing from each side of the neck-a rich greenish blue in colour and very brilliant.

Another common East Indian form is the Bloodbreasted, a rather small species having a crown of feathers and a conspicuous red spot, closely resembling blood, in the centre of the breast.

The largest of all living Pigeons is the Goura, or Crowned Pigeon, a native of New Guinea and some of the neighbouring islands, and a familiar bird in zoölogical collections. This bird has a beautiful crest composed of soft, filmy feathers which rise stiffly in a fan shape over the head and back of the neck, and is always erect. The Goura is about the size of a small Goose, but is quite differently shaped from that bird and has a short, thick neck like the other members of its family. It has a curious habit of shaking its tail 
almost continuously. In colour it is a charming bluishgrey or purplish-grey, with darker shades of purplishred upon the wings. The eye is a deep rich red. The legs are long and heavily scaled. An even more beautiful species, perhaps, is the Victoria Crowned Pigeon, but it does not thrive well in captivity. See Plate 23, Fig. 136.

The Wood Pigeon, also called Ring Dove, is a European species, measuring about seventeen inches in length. The female is hardly distinguishable from the male, being very little smaller and rather duller in colour. The white patch on the neck is a conspicuous mark. Of late years this bird has become very common in London parks, where it is said to show not the slightest fear of man, though in the open country very shy and wary. See Plate 22, Fig. 132.

The Stock Dove is often confused with the following species-the Rock Dove-but it may always be distinguished from it by the absence of the patch of white above the tail. It has somewhat increased in Europe of late years, and shows a marked preference for wooded districts. Rabbit burrows, holes in trees, and matted ivy are chosen as nesting-sites by these birds. See Plate 22, Fig. 131.

Perhaps the most interesting of the Pigeon family is the Rock Dove, since it is probably the ancestor of all our domesticated races. Readily distinguishable by the double black bar across the wings and the white patch on the lower part of the back, this bird is to be found only in a truly wild state where caves or deep fissures in rocks exist. It is a common bird in Scotland and is met with abundantly on the west coast of 
Ireland, where it finds suitable breeding-places in the rugged cliffs facing the Atlantic. See Plate 23, Fig. 135.

Though partial to grain, the Rock Dove feeds largely on the roots and seeds of various troublesome weeds. This and other Pigeons will occasionally, like Gulls, quench their thirst while floating on the water, always in going downstream. In drinking, they do not raise the head, but keep the bill immersed.

The Pouter Pigeon represents one of the most peculiar of all the products of the breeder. By long and careful selection this bird has acquired an enormous crop, which, when the bird is excited, becomes greatly inflated. The long feathers of the legs have also been developed by care in selecting those birds which had legs most inclined to produce feathers. See Plate 23, Fig. 134.

But the races of domesticated Pigeons are legion. Some of the most striking varieties are the Pouter, Fantail, Homing, Tumbler, Owl and Carrier, but in grace and beauty none compare with the wild species.

The smallest species found in this country is the Ground Dove, sometimes also called Mourning Dove, found in many of the Southern States, usually near the coast. Scarcely more than six inches in length, this beautiful little bird is a rosy fawn colour, delicately spotted with different shades of purple, and is almost invisible on the ground as it walks jauntily along, industriously feeding upon seeds and small fruits.

The Mourning Dove, or Carolina Dove, has a wide range throughout North America. The name is de- 
23.

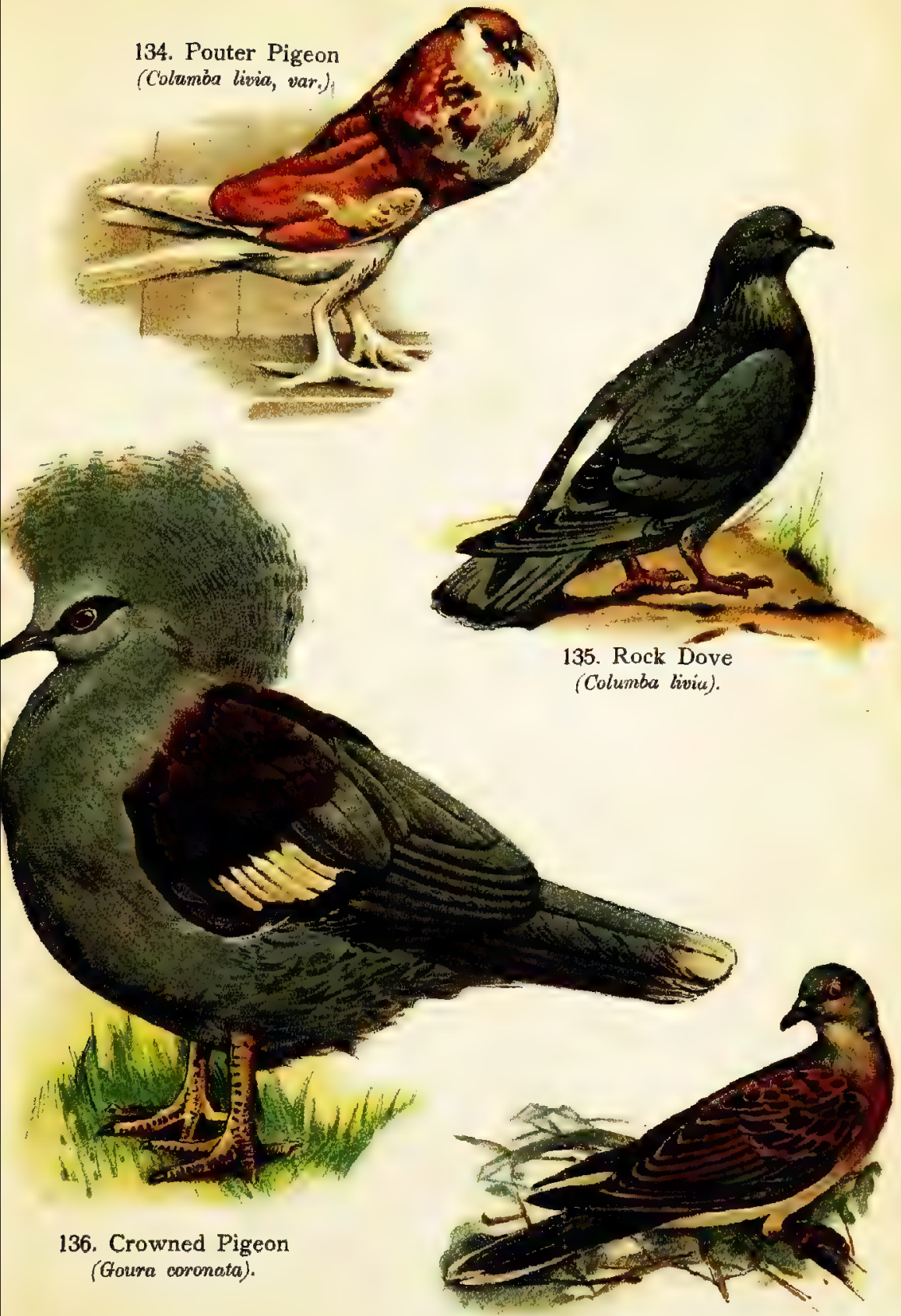

137. Turtle Dove (Turtas turtur). 

rived from the mournful call of the male, which may be heard for a considerable distance. The Zenaida is a somewhat smaller form, closely resembling the foregoing, but has a square instead of pointed tail. It was formerly found in considerable numbers in summer off the coast of Florida.

The White-winged Dove inhabits the southern part of the United States and ranges through the West Indies and Central America. It is distinguished by the white wing-coverts and a wide black mark below the ear.

A large species found in the Western States is the Band-tailed Pigeon. It is greyish above, white below, has a white band at the back of the neck and a dark band across the tail.

The Carrier is a species in which the natural power of flight and the homing instinct have been greatly developed. It is also sometimes called the Homing Pigeon, from the practical certainty with which it returns to its roosting-place after being carried away. The rate of speed attained by these birds has been closely determined, and it is known that the trip from London to Edinburgh has been made by them in considerably less time than is taken by the fastest express trains. But this speed, while very great, is doubtless excelled by that of many other species of wild birds whose habits are not so well known. As might be expected, the form of the Carrier Pigeon is long and trim, and the wing- and tail-feathers are greatly lengthened. A curious abnormal development is the bare skin above the beak and around the eyes.

A well-known and graceful domestic variety is the 
Fantail, in which the tail spreads over the back in the manner of a strutting Turkey-cock. This character seems to be permanent, the birds maintaining it at all times. The Tumblers are so called on account of their habit of tumbling or falling in the air during flight. 


\section{CHAPTER XI}

\section{Parrots and cuckoos}

\section{ORDERS-PSITTACI AND CUCULI}

$\mathbf{P}^{A}$ ARROTS are quite distinct in many particulars from any of the birds so far described. They are a very ancient group and have undergone. such deep-seated structural changes, especially in regard to the skull, that it is not easy to discover what their nearest relatives are, though the Cuckoos are generally accorded this honour.

Among the Parrot's many striking peculiarities the beak is most conspicuous. Not only is it a very powerful weapon, but it also plays an important part in climbing among the branches of trees. It is heavy, sharply pointed and recurved. Some species have the ability to hook the tip of the beak on a branch or the bar of a cage and remain suspended from it for hours at a time.

The legs are very short and the toes are arranged in pairs, two in front and two behind; hence these birds are called $Z$ ygodactyle, or yoke-footed. The use of the foot in holding food and conveying it to the mouth is not confined to Parrots, as certain other birds have this habit. In the true Parrots there is no crest, the tails are square and the upper mandible has tooth-like notches along the edge. 
Parrots are gregarious, flying in large flocks and feeding, roosting and nesting in numbers when possible. They are remarkable tor their harsh and piercing voices, and are extremely noisy, chattering and scolding and screaming when alarmed and also for pleasure. Their food consists principally of fruits and nuts, but they are also insect-eaters, and at least one species, the remarkable Kea of Australia, has developed the habit of feeding on the flesh, particularly the liver, of sheep, since their introduction into that country. The tongue of the Parrot is short, hard and round and has great mobility. It is of much assistance to the bird in eating, rolling the food about in the mouth and placing it in position for the beak to tear or break apart, and also in articulating.

Parrots are among the most brilliantly coloured of birds, bright blue, scarlet, yellow and green being mingled in the most striking contrasts imaginable. Certain species, however, are quite dull-coloured.

Many of them have short, square tails, but the Macaws, the largest members of the family, have very long, pointed tail-feathers.

The beautiful bloom" which covers the feathers of some Parrots and the beak and face of the African Grey Parrot is due to a kind of powder formed by the breaking up of what are known as powder-down feathers.

The Grey African Parrot may be taken as a typical representative of the tribe. It is a very beautiful bird of moderate size, with delicate grey plumage over the body and a scarlet tail. This bird has acquired first place among Parrots as a linguist, and well-trained 


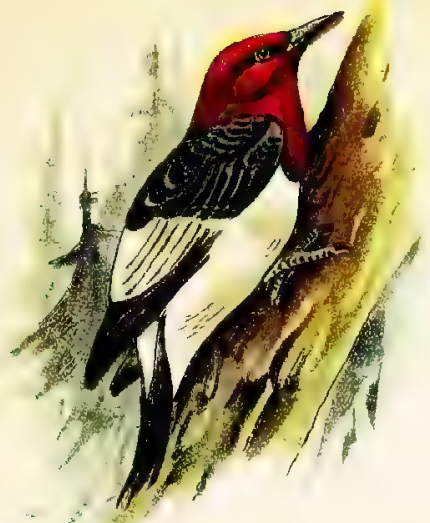

29. Red-headed Woodpecker

(Helanerpes exythrocephalus).
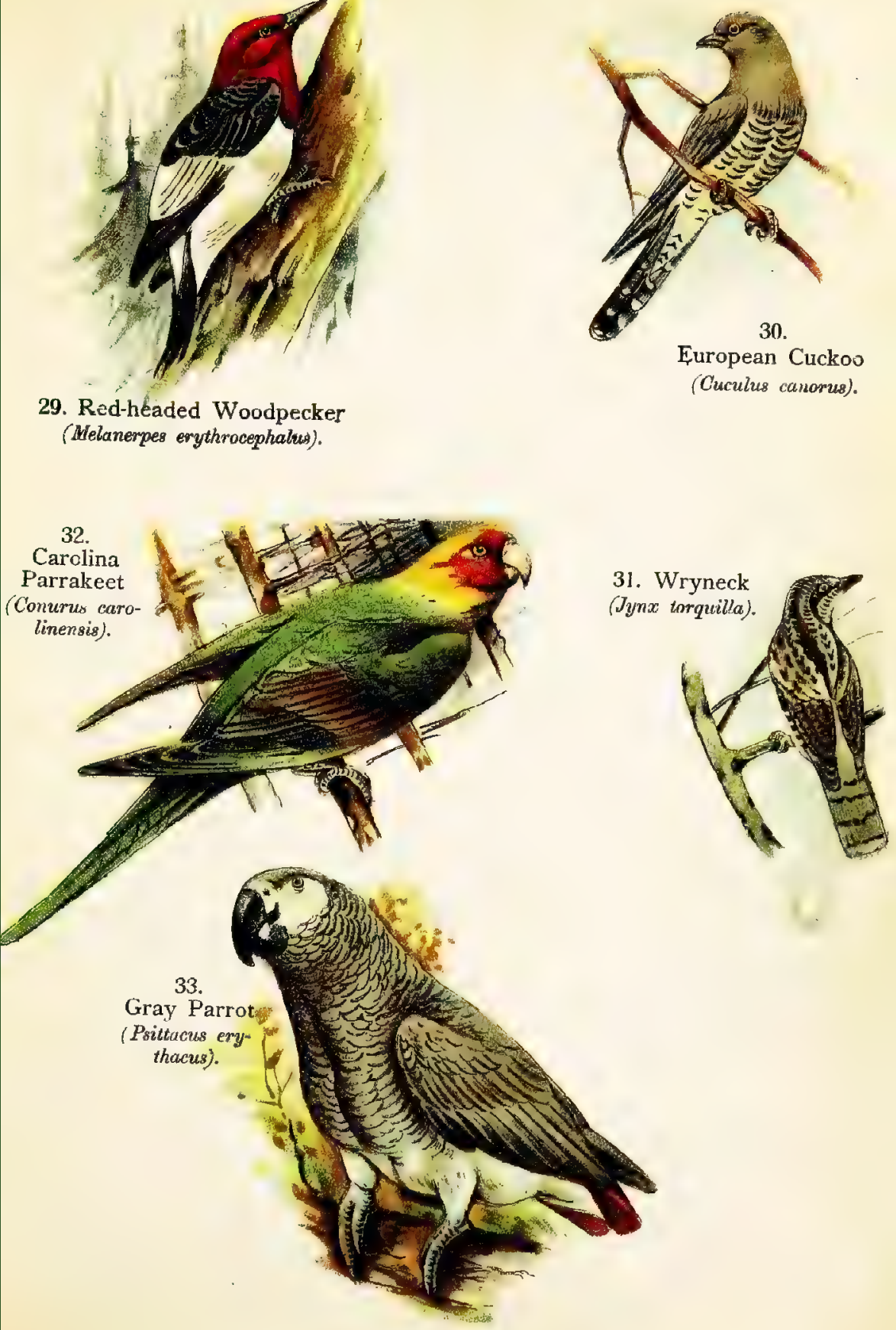

specimens bring very high prices. It ranges across equatorial Africa and is very familiar as a cage-bird. They live for many years, in captivity, and are very interesting, extremely alert and performing many droll and singular antics. The nestlings are naked when first hatched, but soon become covered with a dense, thick down. See Plate \%, Fig. 33.

The Carolina Paroquet, or Conure, was until late years very common throughout the southern parts of the United States; now it is practically extinct, the only breeding-ground known to exist being in one or two counties of Florida. The causes of its extermination are many, but probably the chief one was that it was destructive to crops and fruit-orchards. These birds were easily destroyed from the fact that when one of a flock was injured or killed, the others would assemble about it, and this would happen again and again, so that a hunter was able to shoot numbers of them before any would make their escape.

The colour is a delicate green over most of the body, the head orange-yellow and the bill a rather light fleshcolour. These birds are said to have roosted in a peculiar manner, a number occupying the same hole in a decayed tree and hanging by their bills and feet to the edges. Whether, under the protection now accorded it, the Carolina Paroquet will ever again become common is a matter of doubt. This is the only species native to the United States. See Plate \%, Fig. 32.

The gaudy Macaws, largest of the Parrot tribe, are found only in South America. There are many species. The best known is the Blue and Yellow, which 
is a delicate greenish-blue on the head and neck, shading into deep purple as it nears the tail. The underparts are a brilliant chrome yellow, in striking contrast to the rest of the plumage. See Plate 8, Fig. 34.

Very little is known about the habits of the Macaws in the wild state, but they are said to possess great powers of flight, rising high in the air and travelling long distances in search of food, which consists of various kinds of fruits. The sexes are alike in colouring. In some species the skin below the eyes is bare and wrinkled.

The Red and Blue is dazzling in the brightness of its scarlet and blue feathers, which, however, are not pleasing in texture, being thin and harsh to the touch. These birds are easily tamed and are commonly seen in captivity. See Plate 8, Fig. 35.

The Hyacinthine Macaw is a rich deep blue over the entire body, the naked skin around the eye is a brilliant yellow and the tail is black. In all these birds the feathers are quite loosely set in the skin. The Macaws, like many others of the Parrot tribe, make their nests in tree-holes, which they adapt by means of their powerful beaks to suit their requirements.

The Amazon Parrots are a South American family not found north of Brazil. They are quite small and are coloured in tones of brilliant green and yellow. Many species are known, but all have the same general colour disposed in varying proportions over the body. The species figured is the Blue-fronted Amazon. These birds fly in small flocks and feed on or- 
anges, plantains, berries and other fruit. See Plate 8, Fig. 37.

Most notable among the Australian Parrots is the great Kea. Before the introduction of sheep into that island the food of this bird consisted chiefly of fruit and nuts, but it speedily developed a taste for animal food. These birds will seat themselves on the backs of living sheep and with their long, sharp-pointed bills tear through the wool and flesh in order to reach the liver or kidneys of their victims, inflicting wounds that usually result in the death of the animals. The Keas are large, heavily built Parrots, in colour a dull greenish-brown over the whole body, with the feathers arranged like scales.

Australia is also the home of the Cockatoos, most of which are a delicate cream-white or rosy colour. Some, however, are black. These birds vary greatly in size, some being very large, others among the smallest of the Parrots.

In the Great Sulphur-crested Cockatoo the body is a pure cream-white in tone, the crest a sulphur-yellow. The under-side of the wings is also a delicate sulphur colour.

The Great Black Cockatoo is a most striking-looking bird and the largest of this family. The upper mandible is very large, with strongly-toothed edges. The tongue is unlike that of most Parrots, being long, slender and capable of being extended beyond the beak. The colour of the plumage is jet black, with a purplish bloom over it, due to the white powder from powder-down feathers. The head is decorated with an enormous crest of long, loose black feathers 
and the bare skin around the eyes is red and finely wrinkled.

One of the most remarkable of the Parrot tribe is the Kakapo, or Owl-Parrot, found only in the interior of New Zealand. It is one of the ground-living species and is unable to fly, except for very short distances, although having fully developed wings. The colour, in general, is dark greenish. It is nocturnal in habits, hiding during the day and coming out at dusk to feed on grass-seeds, fruits, and so on. Its resemblance to the $\mathrm{Owl}$ in form and habits has given it its common name.

The Little Budgerigar, or Grass Parrakeet, is another of the Australian birds, rather more of a groundfeeder than most Parrots. It is an extremely common cage-bird, living and breeding readily in confinement. Its plumage is in general dark green, varied in the different species with patches and mottlings of brown, blue and yellow. The flight of this bird is strong and rapid, and while on the wing it is extremely noisy. See Plate 8, Fig. 38.

The Helmet, or Ganga, Cockatoo, found in Australia, is the only representative of its family. The crest of the male, which covers the entire head, is red, the rest of the plumage a greyish colour. See Plate 8, Fig. 36.

\section{Cuckoos}

The Cuckoos are generally regarded as relatives of the Parrots, but rather on account of anatomical characters than likeness in external form. The only respect, indeed, in which these two groups resemble one 


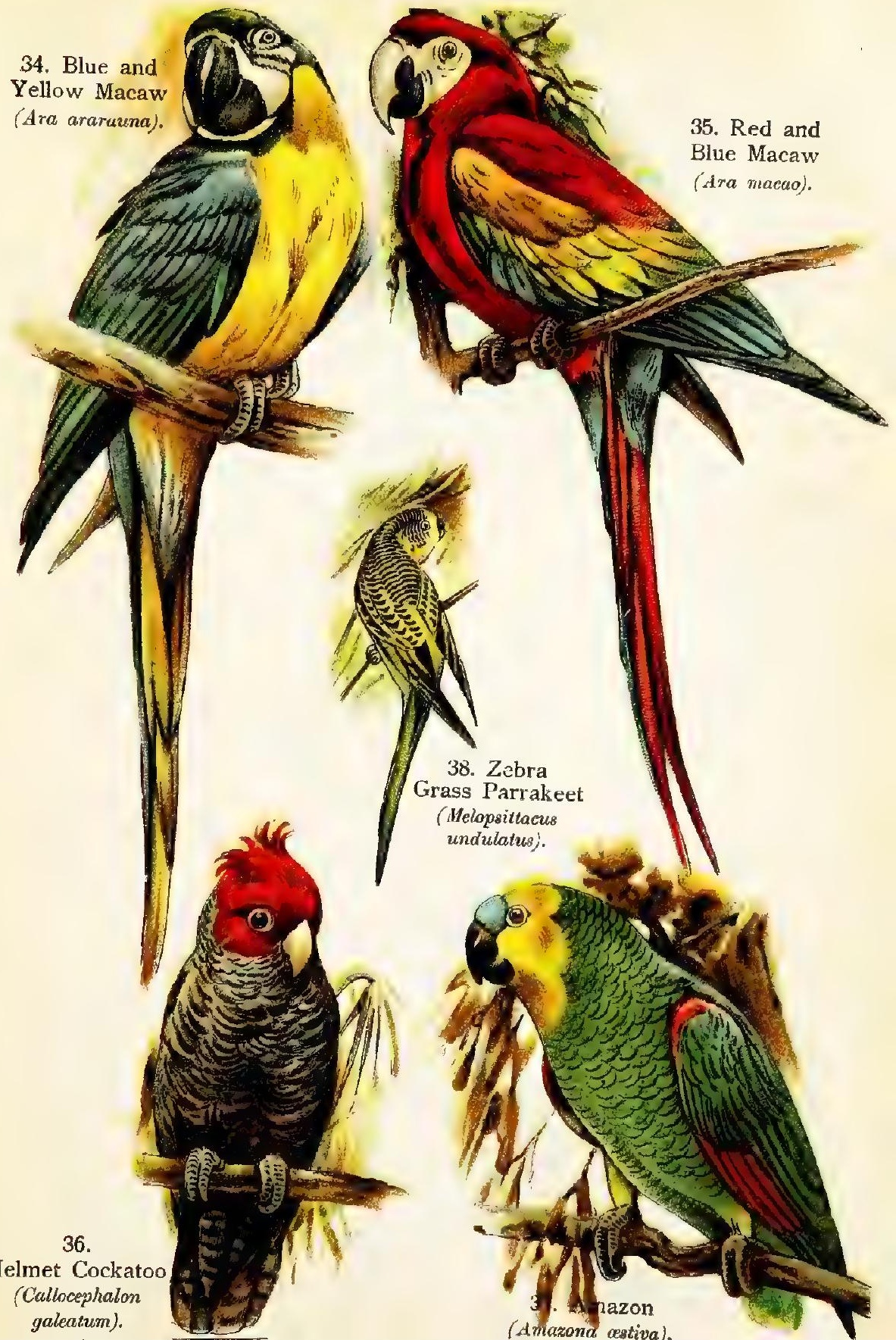



another externally is in the arrangement of the toes, two being directed backwards and two forwards. This division of the toes, however, is not confined to the Parrots and Cuckoos, being shared by many other groups of birds, quite unlike in other particulars.

There are a very large number of species of Cuckoos, showing a surprising range both in size and colouration. Some are wholly black, some resplendent in rich metallic emerald-green and copper, while others are clad in sober hues of grey.

Although comparatively few species are found in America, among them are some of the most remarkable of the Order. Africa and India are particularly rich in Cuckoos.

While the Cuckoos are somewhat solitary in habit, the Anis, an exclusively American branch of this family, are gregarious. A number of them combine in building a nest, in which several females lay and take turns in brooding the eggs. Their powers of flight are not strong, but they are good walkers and runners.

The Yellow-billed Cuckoo is common in the eastern part of North America, migrating in winter to Central and South America. It is greenish-grey above, white below, the outer tail-feathers black tipped with white, the under part of the bill yellow, the upper part black.

The Black-billed Cuckoo resembles the preceding species, but in this the bill is wholly black and the tail is grey, very slightly tipped with white. Its range is much the same as that of the Yellow-billed Cuckoo.

One of the best known of all this family is the Common European Cuckoo, a bird which is found over the 
greater part of the Old World. Its fame is due partly to its wonderful call, "Cuckoo, cuckoo!" and partly to its curious parasitic habits. For this bird, like the American Cowbird, thrusts the charge of its offspring upon other birds, choosing as its dupes such species as Robins, Hedge Sparrows, Wagtails, Thrushes, Larks and Red-back Shrikes. The young Cuckoo almost as soon as hatched ejects the offspring of its foster-parents from the nest, thereby securing an abundance of food for itself. See Plate 7, Fig. 30.

The resemblance which the Common Cuckoo bears to the European Sparrow Hawk, both in flight and colouration, serves it in good stead when seeking victims on whom to thrust its eggs. The male Cuckoo attracts the attention of the other birds and draws them away from their nest, in defending which they do not hesitate to attack even the Sparrow Hawk. The female Cuckoo watches this opportunity to steal up and deposit her egg with those of the absent birds, having first dropped it and then picked it up in her bill. When the infuriated pair return, they either do not notice the additional egg or are so thankful to find their nursery intact that they do not interfere with the egg that has been thus cleverly foisted upon them. The egg of the Cuckoo is extremely small compared to the size of the bird and closely imitates in colour those of the birds to whose care it is committed.

The Ani is common in the Bahama Islands and occasionally seen in the southern parts of the United States. The Groove-billed Ani, another species having the upper mandible ridged, ranges north through Mexico into Lower California and some of the South- 
ern States. In both the plumage is bluish-black with a slight iridescence.

The Road-runner, or Chapparal-cock, is one of the most striking members of the Cuckoo family of the southwestern parts of the United States and Mexico. It is a Ground Cuckoo-that is, it frequents the ground rather than trees-and consequently has long legs, all the other Cuckoos having conspicuously short legs. The plumage is in general olive-brown above, with considerable white and washes of reddish colour, the tail is long and rounded, the outer feathers black tipped with white. The bill is long and sharp and a strip of blue and red skin runs back from the eye. See Plate 41, Fig. 246. 


\section{CHAPTER XII}

Rollers, Motmots, Kingfishers, Bee-eaters, Hoopoes and Hornbills

\section{ORDER-CORACIA}

ПHE Order Coraciæ comprises a remarkable assemblage of birds, mostly of brilliant plumage, and, in the case of the Hornbills, of bizarre shape.

The Rollers, which look rather like gorgeously coloured members of the Crow tribe, have representatives all over the temperate parts of Europe, the whole of Africa and central and southern Asia, but none in America. They are extremely beautiful birds, with long tail, long, pointed wings and rather weak feet. Their food consists mostly of insects, caught on the wing, but they also eat worms and grubs. The dominant colours in their plumage are intense blues and greens. See Plate 9, Fig. 43.

During the mating season the males practise a very curious flight, turning and twisting in the air, at the same time expanding and contracting the tail. But both sexes have the habit of "rolling" or turning somersaults in the air, which has given them their name. They breed in holes in walls, roofs of houses and tree-trunks, laying several glossy white eggs, for 
which they make little or no nest-at best but a mass of roots, grass, hair and feathers.

The Motmots are South American birds about whose position there has been much controversy among naturalists, but which are now thought to be most nearly allied to the Kingfishers. Their colouration is mostly greenish and bluish. In appearance they somewhat resemble the European Bee-eater. Motmots have a peculiar habit, one that is unique among birds and the reason for which is not understood, of deliberately picking away a part of the web from the two middle tail-feathers, leaving a racketshaped end to each. These feathers are two inches longer than the others, and it is said that even the youngest birds of both sexes begin to pick at them as soon as they have grown beyond the others.

The Lesson Mexican Motmot has the crown of the head dark green, encircled with brilliant blue feathers. It is also known as the Blue-capped Motmot.

Among the most beautiful of living birds are the Kingfishers. In size they present a wide range, the largest species, the Laughing Jackass, or Giant Kingfisher of Australia, being about eighteen inches in length, while the smallest are not as big as Sparrows. In colouration also they are wonderfully varied. The species mentioned has head, throat and under-parts buff, wings brownish with the upper coverts spotted with blue, the tail brown, barred with black and tipped at the end with white. This bird receives its name from its strange cry, which it uttered thrice-morning, noon and night.

As a family, the Kingfishers have short bodies and 
long, sharp bills. In some species the toes are arranged three in front and one behind; in others, two in front and two behind, as in the Parrots and certain other groups.

Kingfishers breed in holes in banks, generally by the side of some stream. No nest is made, but the eggs, which are white and translucent, are laid on a bed of fishbones and the hard parts of crustacea that has been ejected by the birds after the soft parts have been digested. The Common European Kingfisher is small, the upper parts are a brilliant blue and the lower parts buff and white. See Plate 9, Fig. 40.

The Common American, or Belted Kingfisher, is much larger than the preceding and has a well-marked crest. The upper part of the body is blue, faintly streaked with darker colour; the throat and sides of the neck are white, as well as the under-parts; the wings are blackish, with white spots on the primaries, and across the breast is a wide band of blue. The tail is barred with white, except the two middle feathers, which are blue. The Belted Kingfisher, like many others of its tribe, has the habit of perching motionless on a small bough overlooking a stream and waiting until a fish comes to the surface, when it makes a quick dart, seizes the prey in its beak and returns with it to the perch, where it is devoured. The feet are very small in comparison to the size of the bird. Like the European species, the Belted Kingfisher nests in holes, digging a tunnel in a bank and widening it at the end for the reception of the eggs. When invaded, the birds will defend their nests vigorously with their sharp bills. 
While the Kingfishers present some species which are dull-coloured, their near relatives, the Bee-eaters, are all brilliantly coloured birds, green, blue and a wonderful rose-red being the principal types, and these colours are, in some, relieved by patches of red and yellow. They are confined to the temperate and tropical regions of the Old World.

Bee-eaters, like Kingfishers, breed in holes in banks or even in tunnels bored almost vertically into the level ground and extending from three to ten feet. These birds have long, pointed wings and long, wide tails. In some species the two outer feathers of the tail are longer than the others. The bill is long and curved and the base of the bill is provided with short, hair-like feathers. Bee-eaters feed upon insects, showing a marked partiality for bees and wasps and appearing to suffer no ill effects from their stings. These birds are common throughout the continent of Europe, and when seen in flocks afford a most beautiful spectacle. See Plate 9, Fig. 42.

By many naturalists thought to be allied to the Bee-eaters and Kingfishers are the Jacamars of South America. In these birds the plumage is brilliantly coloured, the bill is long, slender and sharp and the corners of the mouth are protected by stiff bristles. The feet are small and extremely weak and the toes vary in number in different species.

The Hoopoes are singularly graceful birds, having long, curved and sharply pointed bills and very beautiful plumage. Their wings are short and rounded, legs short, the feet strong and armed with heavy claws. The Hoopoes have a wide range over the whole of 


\section{BIRDS OF THE WORLD}

Europe, northern Africa and parts of Asia. Conspicuous though its colours appear to be, this bird, when alarmed, has the habit of throwing itself flat upon the ground and spreading its wings, when it becomes at once almost invisible. The most striking feature of the Common Hoopoe is its beautiful crest, which can be raised or depressed at will.

Hoopoes breed in holes, and their nests-composed of sticks, straw and a few feathers-give forth an almost overpowering smell. This, however, is produced by the oil-glands of the sitting birds and is not due to the birds feeding upon carrion, as was once thought to be the case. While sitting, the female, who rarely leaves the nest, is fed by her mate with insects and worms. The larger insects, when captured, are tossed in the air and caught again before being swallowed. See Plate 22, Fig. 129.

Black Hoopoes, with red beaks and no crown of feathers, are also found in Africa. The black of the plumage is brightened by a metallic gloss of purple and green, relieved by a white wing-patch and white markings on the tail.

The Hornbills are among the most remarkable of living birds, having bills of enormous size and often further exaggerated by a huge casque which extends backwards over the top of the head.

These birds are natives of India and Africa and the Malay regions. The beaks of the Hornbills, in spite of their frequently very great size, are extremely light, being of the delicacy of filigree work, and covered externally by the horny sheath.

The nesting habits of the Hornbills are very 
strange. After the eggs have been laid and the female begins to sit, the male proceeds to plaster up with mud the hole by which she entered, leaving a small aperture out of which she thrusts her bill to receive the food dutifully brought by her lord and master. This is passed to her enclosed in the lining of his stomach, or gizzard, which peels off, enclosing the fruit or other food he has swallowed. She remains imprisoned until the young are fully fledged.

The Homrai, or Indian, Hornbill, a Malayan species, is a good example of this curious group of birds. See Plate 9, Fig. 39.

There is one extraordinary exception to the rule with regard to the lightness of the beak. In the Helmet Hornbill, of the Malay countries, the forepart of the helmet, or casque, which surmounts the beak is of great hardness and density, and is used by Eastern artists for carving ornaments of various kinds, many of which are of remarkable beauty. 


\section{CHAPTER XIII}

\section{Nightjars, Swifts and Humming-Birds}

\section{ORDERS-CAPRIMULGI, CYPSELI}

T $T$ is now an established fact that the Nightjars are near relatives of the Owls. They may be regarded, indeed, as representing the ancestral stock from which the Owls descended.

The most striking feature of the Nightjars is the huge size of the mouth and the remarkably small beak, which is fringed on either side by long, stiff bristles. These birds also have large eyes and extremely small feet. The former are necessary because the food is largely sought during the twilight hours, while the smallness of the feet is due to the fact that all their food is procured while on the wing. When not flying they remain motionless, either squatting on the ground or along the bough of some tall tree, for these birds are peculiar in that they do not perch like other birds, with the body across the bough, but along it. This unusual method of perching is adopted for protective purposes, for the plumage, which is always of some brown hue, pale or dark, is freckled or powdered with grey, thereby enabling the bird so closely to harmonise with its surroundings as to become well-nigh invisible.

The Common European Nightjar is a representa- 
tive of the family popularly known as "Goatsuckers" from their supposed habit of sucking the milk of goats and cows-a ridiculous superstition, having no foundation in fact. These birds are widely distributed throughout Europe, Asia and the north of Africa. The Nightjar has a wonderful sailing flight, during which it sometimes brings the wings sharply together over the back, producing a loud clapping. It also has a remarkable "churring" note, uttered during the evening hours and in the night. See Plate 19, Fig. 111.

Two creamy white eggs, marbled and veined with brown and lilac, are laid, and these are deposited on the bare ground. The young are hatched covered with down, but are cared for by the parents for some time before they are able to fly.

The Nightjars, or Goatsuckers, of America are the Whippoorwill, the Nighthawk and Chuck-will'swidow. In all the plumage is mottled with black, brown and grey, and is soft like that of the Owls.

The Whippoorwill is very similar in appearance to the European Nightjar, and, like it, is nocturnal in habits, setting forth at dusk in pursuit of its prey. The gape of the mouth is very large and the bill is very small.

This species is found in the eastern part of North America. The male has a white band across the throat; in the female it is buff. The inner web of the three outer tail-feathers is white in the male, buff in the female. This bird receives its popular name from its call, which is rapidly repeated with the accent on the last syllable. 
The Nighthawk has much the same range as the preceding and is frequently confused with it, although it is a distinct species. The colouring is, in general, the same, but the Nighthawk is darker. It has a white throat-patch and a white bar across the primaries. The wings are long and slender, the tail forked, and the bird is very beautiful in flight as it turns and twists in pursuit of insects. It is chiefly nocturnal in habit, but is frequently seen early in the evening as well as on cloudy days. It has a peculiar hoarse cry.

The Chuck-will's-widow is a more southern species than the other two mentioned and is a larger form. In the male the inner vane of the outer tail-feathers is white, the outer vane barred with buff and black. It has a loud cry, from which it takes its name.

\section{SwIFTS}

The Swifts bear a close superficial resemblance to the Swallows, with which, indeed, they are always associated in the popular mind. As a matter of fact, however, they are in no way related, the Swifts being near allies of the Nightjars. They are long-winged birds and have tremendous powers of flight. The legs are short, the feet extremely weak, and it is with great difficulty that they can rise from level ground. They are insect-feeders, catching their prey while on the wing. In the true Swifts the toes all turn forward, enabling the birds to cling with ease to vertical surfaces.

The Common European Swift is very abundant throughout Europe during the summer months, leav- 
ing early in the autumn for their winter quarters in Africa. Their flight is marvellously rapid, as they chase each other about in the dusk of evening, sometimes high in the air and sometimes near the ground, uttering their shrill cries. See Plate 18, Fig. $10 \%$.

This bird, which is known also as the Deviling, occurs all over Europe and parts of Asia and Africa.

The so-called "Chimney Swallow" of Eastern North America is really a Swift. These birds are gregarious, usually being seen in large companies. Originally their nests were built in the holes of decayed trees, but many of them now use the chimneys of houses for this purpose, building nests of small sticks glued together and attached to the walls of chimneys with saliva. In perching, they use the stiff and sharply pointed tail-feathers as a prop for the body while clinging to upright surfaces.

There are seventy-five known species of Swifts in the world, only four of which are found in North America.

\section{HuMMING-BIRDS}

That the Humming-birds and Swifts are very closely related no one now doubts, unlike though they be in external appearance.

Confined to the American Continent, and ranging from the extreme south thereof as far north as Canada, these birds are by no means to be regarded as the jewelled darlings of the tropics, though it is indeed in tropical America that they are to be met with in the greatest plenty. Numbering no less than four hundred species, they present a relatively great range 
in size, the largest measuring nine and a half inches, while the smallest is but little bigger than a bumblebee. In the matter of the shape of the beak and tail they present hardly less variety. Thus the beak may be short and straight, curved upwards or downwards, or drawn out into a great probe, considerably longer than the whole body. The tail may be short and rounded or long and Swallow-like, and in some species these long tail-feathers cross one another in graceful curves, while in others these crossed feathers are drawn out into mere threads, terminating in oval expansions.

But it is on account of the exquisite beauty of their plumage, resplendent in the most gorgeous metallic hues, that the Humming-birds have become so famous. No other birds can vie with these fairy-like creatures in this respect.

One of the most elegant, though by no means the most gorgeous of all, is the Double-crested Humming-bird, a native of Brazil. See Plate 21, Fig. 121.

The Coquette Humming-bird is a native of Central America. Ten different species of Coquette Humming-birds are known, ranging from Mexico southwards. They are easily distinguished by their crested heads and the "ruff," which projects from the throat. See Plate 21, Fig. 122.

Perhaps the most gorgeous birds in existence in so far as the colouring of the tail is concerned, are the Fire-tailed Humming-birds. Three species are known. They inhabit Peru, Bolivia and the Argentine Republic. See Plate 21, Fig. 123. 

The Topaz Humming-birds are hardly surpassed by any other members of this group in brilliancy of plumage. They are distinguished by the two long middle tail-feathers, which cross one another in graceful fashion. The species here figured is a native of the Rio Negro. See Plate 21, Fig. 124.

Not the least remarkable of the many peculiarities which distinguish the Humming-bird is the curious way in which some develop a kind of "powder-puff" around the legs. This is well seen in the Racquettailed Humming-bird, of which six species are known, inhabiting South America from Venezuela and Colombia, through Ecuador and Peru, into Bolivia. See Plate 21, Fig. 125.

As we have already remarked, these birds are by no means confined to the tropics. They have been seen flitting about the fuchsias of Terra del Fuego in a blinding snowstorm, and they are met with on the lofty mountains of Chimborazo as high up as 16,000 feet, dwelling in a world of almost continuous hail, sleet and rain.

These wonderful birds feed chiefly on insects which harbour amid the petals of honey-bearing flowers. To procure these they have developed a most remarkable tubular tongue of complex structure, which is so contrived as to suck up the honey and insects at the same time.

Beautiful as these birds appear in pictures, they are far more beautiful in life, for no picture can possibly represent the superb play of colour which takes place with every movement of the body. Though stuffed specimens lose much of their beauty, they re- 


\section{BIRDS OF THE WORLD}

tain sufficient of their glory to dazzle us. At times these tiny bodies glow as with some internal fire, at others they appear dull. As the spectator changes his place, green turns to gold, and gold to black, and back again to gold and green, and a dozen other intermediate hues, according to the intensity and incidence of the light. One must see Humming-birds to realise their surpassing beauty; no brush can depict them nor can words describe them.

The Ruby-throated Humming-bird is a very beautiful species, about three and a half inches in length, found in the eastern part of North America, breeding from the southern border as far north as Labrador. The upper parts are brilliant green, wings and tail brownish-grey, and the throat and exquisite ruby-red. The female is similarly coloured, but lacks the red throat of the male. These birds are said to spend much of their time perched motionless in trees, going at intervals to certain places to feed. They are remarkably fearless and may be closely approached without taking alarm. The nests are beautiful little structures, lined with the softest down and sometimes with spider-webs, and the eggs are always white and two in number. The young are fed by the parents on small insects, which they regurgitate.

In the Old World the place of the Humming-birds is taken by the Sun-birds, which resemble them in general appearance and in habits, but are not so brilliant in plumage. Their wings are shorter and more rounded and their feet are stronger. Unlike Humming-birds, which take their food from flowers while 
hovering on swiftly moving wings, the Sun-birds usually perch when feeding. The male bird assumes quite gorgeous raiment during the breeding season, but this is moulted afterwards and replaced by the more sober colours of his mate. 


\section{CHAPTER XIV}

\section{OWLS \\ ORDER-STRIGES}

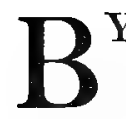

$\mathrm{Y}$ the older naturalists Owls were regarded as near relatives of the Accipitrine birds, such as Hawks and Eagles. This was because of their similar beaks and claws and their common habits in feeding. It has, however, been conclusively shown that Owls are very closely related to the Goatsuckers.

These birds are spread over a very large portion of the globe, being found in all the continents and many of the islands. They vary greatly in size, some being but a few inches in height, while others measure several feet. Most species are nocturnal in habits, but certain others feed by day. The plumage of Owls is remarkably soft and fluffy, rendering their flight practically noiseless and enabling them to pounce upon their prey without giving alarm.

The foot in most Owls is feathered to the toes; the claws are remarkably long and sharply pointed and the foot is used with great dexterity in seizing. The outer front toe and the hind toe are placed somewhat more closely together than in most other birds, but the toes are not divided into pairs, two in front and two behind, as in the Parrots and Cuckoos. Stiff bristles project from the toes on each side. 
The beak of the Owl, although sharply hooked and used to tear the prey, is not nearly so powerful as in the true Birds of Prey, but more closely resembles that of the Nighthawk and Whippoorwill. The eyes are very large and are fixed in their sockets so that they cannot be turned, the bird being obliged to move its head in order to see at the side or behind it. The eyelids are heavy, and the nictitating membrane, or inner eyelid, is fully developed. Any one looking at an Owl in the daytime will see this thick membrane frequently sliding across the eyeball as the bird gazes sleepily about.

Owls are fierce and aggressive in character. When disturbed, they fluff out their feathers, lower their heads, and give vent to a loud, hissing sound, at the same time clattering their mandibles together. When in this attitude, nothing in the bird world is more sinister in appearance: The voice of Owls is unlike that of any other bird, and while it differs in various species, is yet somewhat similar in all. The word "hoot" is used to describe it. Sometimes this note is uttered once and repeated at intervals, and again it will be given several times in quick succession. It is varied by strange coughs and hisses, and at times is very loud and far-reaching.

Owls have always occupied a prominent place in the traditions and literature of the peoples of the world. They were practically worshipped by the ancient Romans, Greeks, and Egyptians,-who looked with reverence upon this strange, usually silent, bird, and it is even now used as an emblem of wisdom, though by no means a very intelligent bird. 
The nocturnal Owls feed principally at dusk, when the small mammals upon which they prey are also abroad. Some species, such as the Great Horned Owl of North America and the Eagle-Owl of Europe, feed on quite large game, such as wild Turkeys and small deer, but the food of most Owls consists of such small creatures as mice, rats, frogs, lizards, and small reptiles. Most species have the remarkable habit of swallowing their food whole, when not too large, and afterwards ejecting the hair, bones, and feathers, in the form of small pellets.

The nests are usually made in the hollows of trees, and the eggs are always white. The number varies in different species. The young are hatched covered with down, and are carefully tended by the parents until they are able to leave the nest.

Owls are sombrely coloured, most of them being mottled in various shades of brown and buff intermingled with white and sometimes black, but in no case is there any really brilliant colour in the plumage. They have remarkable control over the form of their bodies, at times making themselves appear long and slender; at others, short and rounded.

These birds are divided into two general classes, those that have ear-tufts, or horns, and those that lack them, the former embracing a large number of species.

The largest and perhaps best known Owl in the United States is the Great Horned Owl, celebrated both for its ferocity and for its remarkable voice. It feeds on large game, when pressed by hunger attacking even the wild Turkey. This sagacious bird, however, often eludes its enemy by waiting until the OwI 
is about to descend upon it, then spreading the tail feathers over its back so that the Owl slides off the slippery surface and the Turkey has time to escape before a second attack can be made.

During the day this Owl flaps helplessly about in the cover of the woods, endeavouring to conceal itself from its enemies, but at dusk it emerges and stares about with its magnificent yellow eyes opened to the widest extent. Its sight then is remarkably keen, the tiniest mouse being seen at a great distance and silently pounced upon. The claws of the Great Horned Owl are extremely long and sharp, and the grasp of the foot very powerful. This Owl shows great preference for the flesh of the skunk, almost every specimen captured reeking with the nauseating odour of that animal. The long talons are driven into the vitals, and the victim is quickly despatched.

In this species the ear-tufts are greatly developed, and are raised several inches above the side of the head, giving the singular horned appearance. In colour individuals vary considerably, but in general they are different shades of buff and brown, splotched and striped in a confused pattern. This intermingling of colours is of great service in concealing the bird from view, and when seated in an upright position on the stump of a dead tree, it is almost identical in tone and therefore practically invisible.

The Great Eagle-Owl of Europe differs but little from the Great Horned Owl of this country. See Plate 5, Fig. 18.

The voice of the Great Horned Owl is loud and startling. Mr. Chapman describes it as "a loud, deep- 
toned whoo, hoo-hoo-hoo, whooo, whooo, the syllables all on one note, and bearing some resemblance to a bass-voiced dog barking in the distance. A much rarer call," he says, "is a loud, piercing scream, one of the most blood-curdling sounds I have ever heard in the woods." At other times hisses and groans come from the throats of these birds-apparently a sort of conversation with them.

The Snowy Owl is an Arctic species of both the Old World and the New. In the winter it wanders as far south as the United States. It is a large and handsome form, differing considerably in colour in individuals. Some are almost pure white over the whole body, while others are thickly spotted with black. The eyes are extremely large and light yellow in colour, forming a striking contrast to the beautiful white of the feathers around them. See Plate 5, Fig. 23.

This bird sees with perfect ease in the daytime, and is very shy, keeping well out of the range of a gun. Its food consists of small mammals, Ptarmigan, Grouse, and Ducks, and it is said also to catch fish.

The Little Owl is an Old World form, about eight inches in length. A native of the continent of Europe, it has of late years been introduced into the British Islands, where it now breeds well and is increasing in numbers. See Plate 5, Fig. 22.

The Coquimbo, or Burrowing Owl, is found only in North America, and is the only species that lives and breeds underground. It is about ten inches in length, has no ear-tufts, and the feet are but slightly feathered. The legs are longer in proportion than 

are those of most Owls. The Western species lives in burrows made by prairie-dogs_although certainly not welcomed by them. But the Florida Burrowing Owl digs a hole for itself. They are day-feeding, being perfectly able to endure the fierce glare of the sun in the regions in which they live.

The Tawny Owl is an interesting species, having two distinct phases of plumage, some individuals being very grey, while others are red in colour. This Owl is further peculiar in that the apertures of the ears are not alike in the two sides of the head, though both are covered by a large flap of skin. See Plate 5, Fig. 19.

The European Long-eared Owl is another species in which the apertures of the ears are unlike. It is common in European countries, and is very beneficial, destroying large numbers of mice and other small rodents. The American Long-eared Owl is similar in appearance. See Plate 5, Fig. 20.

The Long-eared Owls and the Short-eared Owls, though very much alike superficially, differ conspicuously in their nesting-habits. The former deposit their eggs in the deserted nests of Crows, Hawks, Herons, or squirrels, while the Short-eared species nests on the ground in hollows made in weeds and sedge. The eggs vary in number from six to twelve. During a great plague of voles which occurred in Scotland a few years ago, these Owls, finding food in abundance, reared broods twice in the year and double the normal in number.

The Barn Owl, or Monkey-faced Owl, found in both the Old and the New World, is not only a beau- 
tiful species, but forms a group by itself apart from the rest of the Owls, differing from them in structure. The colouration differs in certain parts of its range. The eyes are almost black, as in the Tawny OwI, while in most Owls the colour of the iris is a bright orange-yellow. The Barn Owls are without ear-tufts, and the disks about the eyes, instead of being round, are irregular in shape. See Plate 5, Fig. 21.

The young Barn Owl is at first clothed in a downy coat of white, and this is replaced by plumage like that of the adult bird. In most, if not all, other Owls the down-feathers of the nestlings are replaced by a plumage that is intermediate between that and the adult feathers, and this is worn until autumn, when the true feathers appear.

The Barred Owl, or Hoot Owl, is a common species in Eastern North America. The under parts are white, the breast barred with dark colour, and the sides streaked. The eyes are dark, and the toes are feathered.

The Great Grey Owl is a northern species, occasionally seen in the United States. It is a very large form, having the upper parts dark irregularly marked with white, the under parts streaked, and the legs and toes feathered to the claws.

The Little Screech Owl is perhaps the best known of our American Owls, being common in the woods throughout the Eastern States. Its voice has a low and tremulous quality, and is often heard in the evening hours. A peculiarity of this species is that it has two phases of colour, one reddish in tone, the other greyish, both varieties being found at the same time 
in the nest. The Screech Owl has well-marked eartufts.

The American Hawk Owl, so called from its Hawk-like appearance and character, is another species found in the northern part of North America and occasionally seen in Europe. It is dark brown above, spotted with white, and has the under parts barred. The tail is longer than in most $\mathrm{Owls.}$ This bird is one of the most rapacious of the Order to which it belongs. As in all Owls, the female is larger than the male. 


\section{CHAPTER XV.}

Trogons, Toucans, and Woodpeckers

\section{ORDERS-TROGONES AND PICI}

THE precise relationship of these birds has not yet been decided, though probably all are akin. The Toucans and Woodpeckers are certainly more nearly related one to another than to the Trogons, which form a rather isolated group.

The Trogons are represented by many species, some of which are of surpassing beauty. Some are natives of tropical America; others occur as resident species in Africa, a large part of India, and the Malayan countries. In ancient times they occurred in Europe, fossil remains of Trogons having been found in France. The American species are distinguished by their barred tails.

As their small, weak feet would indicate, these birds are tree-living, and feed while suspended in the air, their diet consisting of berries and insects. The sexes differ greatly in colouration, the males being much more brilliantly attired. The Trogons are "yokefooted," like Cuckoos and Parrots, but they differ from them, as well as from all other known birds, in that it is the first and second, instead of the first and fourth, toes which are directed backwards.

The Narina Trogon is an African species, ranging 
from northeast Africa to Cape Colony. It is a very shy bird, hiding in the deep recesses of the forests, and is seldom seen. It has a curious wheezing call. See Plate 9, Fig. 44.

The Resplendent Trogon is a large and beautiful species found in Central America. The upper parts of the body are golden-green, the breast and under parts a brilliant red, the middle tail-feathers are black, while the outer ones are white, barred with black.

In the Cuban Trogon the upper parts are green, the top of the head washed with blue, the throat, breast, and under surface of the tail a delicate grev, the primaries black, spotted with white, and the bill scarlet.

But the most magnificent of all the Trogons is the Quetzel, of Central and South America. The upper parts of this bird are brilliant green and blue, the under parts a gorgeous crimson, and it has a long and gracefully flowing tail consisting of the lengthened coverts, which extend from one to two feet beyond the other tail-feathers. In olden times the native chiefs wore these plumes on days of high festivals.

\section{Toucans}

So far as outward appearance goes, the Toucans have many characters resembling the Hornbills, the most conspicuous among them being the enormous beaks. On this account they are frequently mistaken one for the other by those who are not very familiar with them, but, as a matter of fact, these birds are not closely related. 
There are several species of Toucans, some of which are sombrely attired, but many of them are quite richly coloured. They range in size from a rather large thrush to about two feet in length.

As in the Hornbills, the beak is extremely light and porous, ensheathed in a very thin case of brightly coloured horn, which is serrated, or notched, along the cutting edges. They have the curious habit of sleeping with the head turned back and the tail brought forward, so that both rest on top of the back.

Both Toucans and Hornbills are awkward on the ground, hopping about with the legs far apart. In the trees, they spring lightly from branch to branch. They stare about them with a curious slow movement of the head and beak from side to side, unlike that of most birds, which is quick and rather jerky. All these birds are fruit-eaters, but their diet is varied by insects, as well as small birds and mammals.

One of the largest of the Toucans is the Toco, or Giant Toucan. It is widely distributed throughout South America, and is met with in rather large flocks.

The Short-billed Toucan is a smaller species, found from Costa Rica to Northern Columbia. The plumage is black and red, and the bill is varied with red, blue, green, and yellow. See Plate 9, Fig. 41 .

\section{WOODPECKERS}

Woodpeckers are an extremely interesting group of birds that illustrate to a remarkable degree what is meant by "adaptation to environment." That is to say, they show, by their many singularities of structure, that they have become changed, or "adapted," 
so as to fit them for their peculiar mode of life. The most obvious of these changes are in the shape of the beak, the tail, and the feet. Their food consists of insects and grubs which they find concealed in the bark of trees. The beak is wedge-shaped and sharply pointed, and has a horny sheath of unusual hardness, enabling the bird to peck away the bark in search of its prey, and also to dig the holes in which it makes its nest. The toes are placed two in front and two behind, and are furnished with long claws, which serve the purpose of grappling-irons. Finally, the tailfeathers are of a curious spiny character, and these serve as supports when the bird, having firmly fixed itself by its claws, begins its work of excavation. The Woodpeckers are essentially tree-dwellers, and after a peculiar fashion, for they spend most of their lives, not in perching on the boughs, but in climbing up and down the trunk. The spiny tail-feathers are developed in proportion to the amount of hammering which must be performed to gain a livelihood. They afford, in short, a very effective leverage during the time that the beak is being used as a "pick."

But the peculiarities of the Woodpeckers do not end with these external characters. The tongue, for example, is of enormous length, and its roots, or supports, are excessively developed, so that they curve round and over the skull, to be finally stowed away in a channel above the beak. This tongue is used as a trap for the capture of ants and other insects. Thickly covered with a sticky saliva, which has been compared to bird-lime, this wonderful and worm-like organ is suddenly thrust out amid swarms of ants, which are 
borne back into the mouth, struggling helplessly. The saliva is secreted by a pair of enormous glands on each side of the head. The head of Woodpeckers is set in a peculiar manner, being at right angles with the body - a natural position, considering that the bird must remain upright in feeding, when the head is used as a hammer.

Nearly all Woodpeckers have a crest at the back of the head, which may be slightly raised or lowered. This crest is usually a brilliant red, and in many species it is the only spot of bright colour on the bird.

America is peculiarly rich in Woodpeckers, about one half of the three hundred and fifty known species occurring in this continent and displaying a wonderful diversity of plumage. These birds, however, are found all over the world, except in the Australian region, Madagascar, and Egypt.

The Ivory-billed Woodpecker is the largest of the American species, measuring twenty inches in length. The general colouring is black and white, and there is a large scarlet crest. Running from the eye down the neck and half way down the back on each side is a conspicuous white stripe. The lower half of the primaries is white, and the under parts are a glossy black. The bill is ivory white. This handsome bird is extremely shy, and is found only in the forests of the Gulf States and in the Lower Mississippi Valley. See Plate 6, Fig. 25.

The Great Black Woodpecker is a large European species, in which the plumage is entirely black except for the red crest. Attempts have been made to acclimatise these birds in the British Islands, but with- 

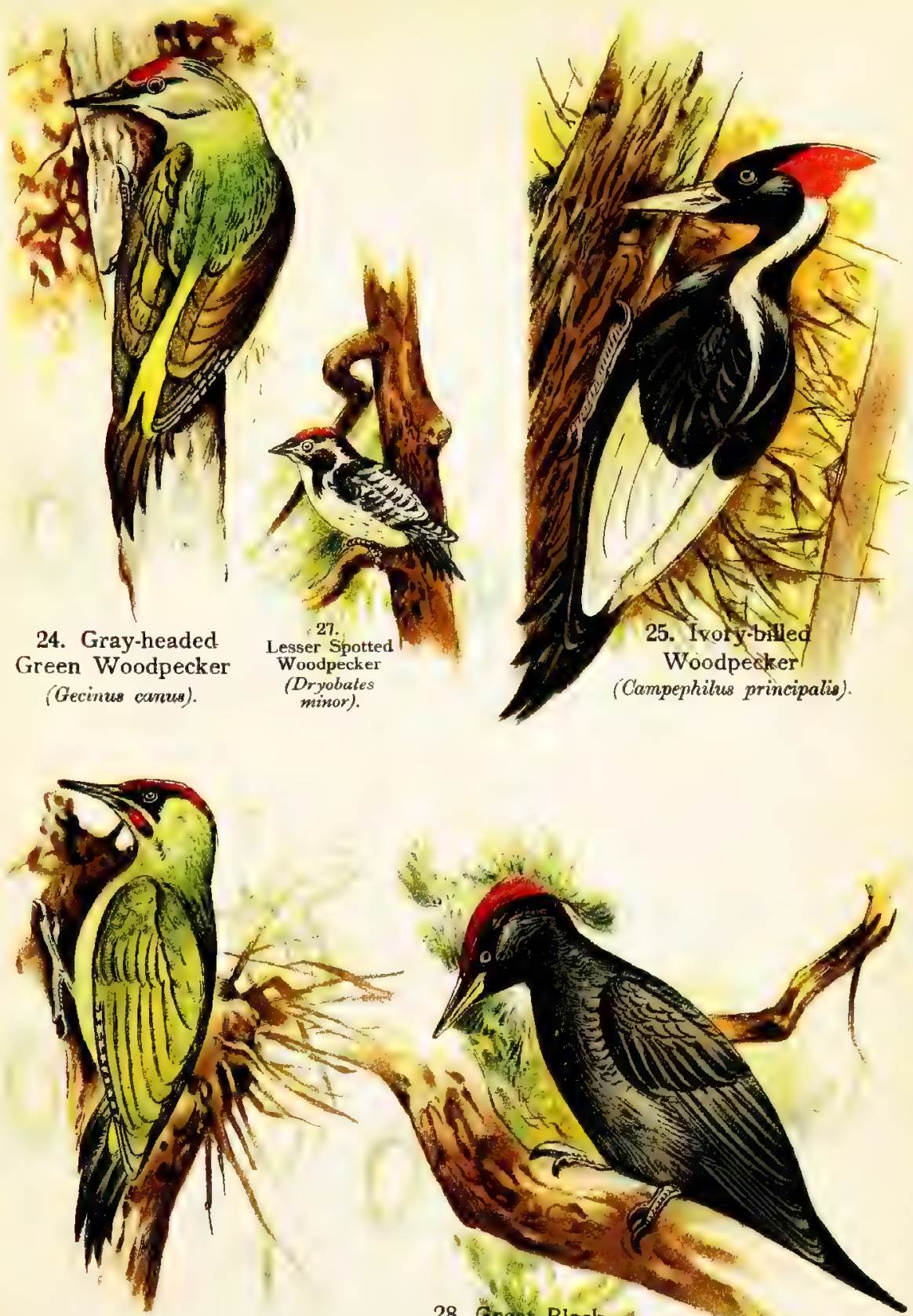

26. Green Woodpecker

(Gecinus viridis).

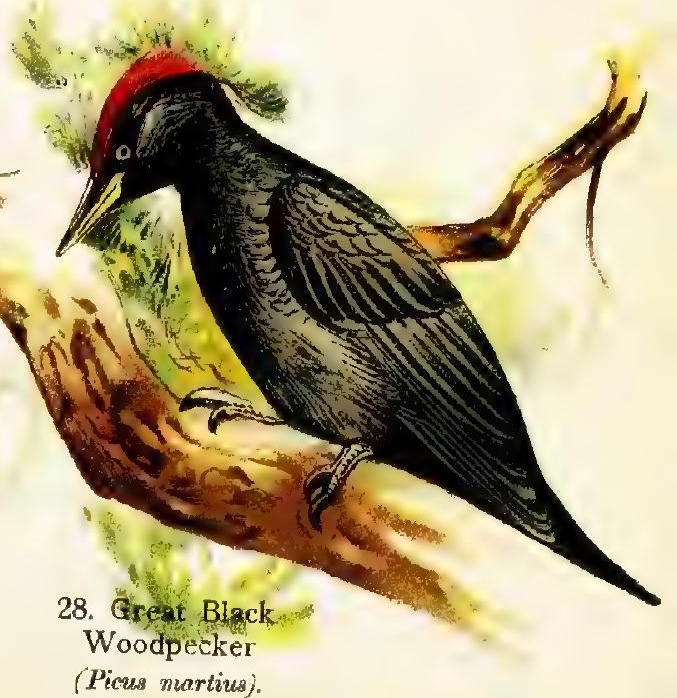



out success. This bird corresponds to our Pileated Woodpecker, being about the same size. See Plate 6, Fig. 28.

The Red-headed Woodpecker is found in the eastern part of the United States. The whole head, neck, and throat in this species is red; the upper part of the back is black, as well as the primaries and tail; the rest of the plumage is white. The combination of colours makes this bird quite conspicuous when on the wing. See Plate 7, Fig. 29.

The Green Woodpecker is very common in Great Britain, where it is also known as the Yaffle, as well as by many other provincial names. The female has black upon the cheeks where the male has red. See Plate 6, Fig. 26.

The Grey-headed Green Woodpecker is a near relative of the preceding species, and is common throughout Europe and Asia. See Plate 6, Fig. 24.

The Lesser Spotted Woodpecker is a very small form found in Europe, Asia, and parts of Africa. Its plumage is mingled black and white, and there is a red crest at the back of the head. Owing to its small size and its partiality for tall trees, such as elms and poplars, this bird is not often seen. Its near relative, the Great Spotted Woodpecker, is a much larger bird, and corresponds to the Hairy Woodpecker of this country; while the smaller form more nearly resembles our Downy Woodpecker. See Plate 6, Fig. 27.

The Yellow-bellied Sapsucker is common in the eastern part of North America. It feeds on the juice of trees, which it extracts by boring holes in the bark. The tongue in the Sapsuckers is not extensile, as in 
the true Woodpeckers. In this species the crown and throat are red, the back is irregularly marked with black and white, with a yellowish tinge, there is a black patch on the breast, and the under parts are pale yellow.

The Common Flicker, or Golden-winged Woodpecker of the United States, is a very beautiful bird, differing in habits from the other members of its family. In colour it is very charming, a delicate pinkish grey over most of the body, the under surface of wings and tail a bright golden yellow, the under parts white, washed with yellow and thickly spotted with black. There is a band of red across the back of the neck, a black crescent on the breast, and a black patch on each side of the throat. This bird has many popular names, High-hole being one of the most common.

Unlike other Woodpeckers, the Flicker spends much time on the ground. It nests in holes in trees, however, like other members of the group, and lays from five to nine white eggs.

Though in its colouration unlike the typical Woodpeckers, the Wryneck, or Cuckoo's-mate, nevertheless is of the Woodpecker tribe. In the soft, mottled grey and brown colours of its plumage, this bird more closely resembles the Goatsuckers. The tail-feathers, too, as may be seen in the figure, are not stiff and pointed, as in the typical Woodpeckers, but are soft and rounded. These birds never use their beak, which is small and delicate, as a pick; hence they have no need of support from spiny tail-feathers. But the Wryneck is undoubtedly a Woodpecker, in spite of these differences, as is shown by the structure of the 
tongue, as well as by other common characters. See Plate 7, Fig. 31.

Like all the other Woodpeckers, the Wryneck lays several glossy white eggs in the hollow of some decaying tree, making no nest, but using the rotten wood at the bottom of the hole. When disturbed, the sitting-bird makes a loud hissing noise, which induces one to suppose that the hole is occupied by a snake, and this usually secures freedom from further interference. On this account, as well as from the remarkable way in which the bird twists its neck, the name Snake-bird has been bestowed upon it. When taken in the hand, the Wryneck, like some other birds, feigns death so successfully that it often escapes. 


\section{CHAPTER XVI}

\section{The Passerine Birds}

\section{ORDER-PASSERIFORMES}

$\mathbf{I}^{\mathrm{N}}$

$\mathbf{N}$ this chapter we shall describe some families of what are known as the Passerine, or Perchingbirds. These, though preserving a remarkable sniformity in so far as their anatomical characters are concerned, present an amazing variety superficially, as in colouration and in the form of beak, so much so that nearly six thousand distinct species are known to science.

Though all are essentially tree-dwellers, many species have come to pass much of their time in low scrub or in the open country. Some possess remarkable powers of flight, while others are practically unable to fly.

This great series may be divided into two more or less sharply defined groups, based partly upon the structure of the syrinx, or voice-organ, and partly upon other anatomical characters.

The first of these groups may be sub-divided so as to form three smaller groups, distinguishable partly by means of characters afforded by the voice-organ, and partly by other anatomical characters; all of which are too complicated to come within the scope and purpose of this volume. 
The first of the two large groups just referred to form the

\section{Sub-ORder-Clamatores}

The birds herein placed, though regarded as nonsinging birds, yet include a few species with melodious voices; though none have a song comparable to that of such songsters as the Nightingale or the Thrush or the Mocking-bird. But it is not, as has been said, the quality of the song so much as the number of song-muscles and their arrangement that is considered in this connection.

Included among the Clamatores are the birds known as the Broadbills, or Eurylæmidæ, of East India, some of which are very beautiful. Very closely allied to some of these are the Cotingas, of which the most gorgeous is the Cock-of-the-Rock, a native of South America. This bird is shy and solitary in habits, living among the rocks along the river-banks. The whole plumage is brilliant orangered, with the exception of the primaries, which are brown with yellow tips. A thick crest of feathers runs from beak to the back of the head, and long, soft plumes fall from the upper wing- and tail-coverts.

During the mating season, the birds gather in small companies and the males go through with a weird kind of dance, in which they droop their wings, wave their crests from side to side, and hop along in a peculiar manner. See Plate 19, Fig. 112.

Closely related to the Cock-of-the-Rock are the Bell-birds, also of South America, of which four species are known. The Naked-throated Bell-bird, 
the one illustrated, is pure white in colour. Another species has a long, fleshy wattle hanging from the base of the beak like the wattle of a Turkey. It stands straight up when the bird is excited. The home of the Naked-throated Bell-bird is in Brazil, where the gloomy forests resound with its wonderful notes. These resemble the sounds made by a clear ringing bell, or, according to some travellers, the sound produced by a blacksmith when he strikes a piece of steel on an anvil. The song is heard at all hours of the day, and when, as often happens, several of these birds are in the same neighbourhood and answer one another's calls, a wonderful concert is the result. See Plate 10, Fig. 48.

\section{American Flycatchers}

Among the non-singing Passerine birds are classed " the American Flycatchers. This family numbers about three hundred and fifty species, and is confined exclusively to the New World. By far the greater number of these are found in the region of the tropics, but as many as thirty-five species occur in North America. In colouring the sexes are much alike, and the nestlings resemble the parents. The prevailing tints are olive-grey and brown, with touches of yellow on the under parts. A few species, however, have patches of bright-coloured feathers.

Flycatchers are notable for the width of the beak opening, as in the Goatsuckers, and for the bristles at the angle of the mouth which are of assistance in capturing their insect prey. The method of pursuing and catching insects is characteristic of this entire family. 
The bird perches upon the branch of a tree, and, motionless and upright, awaits the passing of victims. When one comes within sight, the Flycatcher darts from its perch, pursues, and usually captures the flying insect with a snap of the bill, and invariably returns to the branch from which it started. Preying almost entirely as they do upon insects, these birds are necessarily migratory, leaving their northern summer haunts for a warmer climate in winter.

The Kingbird, or Tyrant Flycatcher, is one of the largest of American Flycatchers, and gets its name, "Tyrant," from its pugnacious disposition. Owing to its powers of flight and its great courage, this bird attacks without fear much larger species, such as Hawks, Owls, and Crows, driving them away from its chosen haunts whenever they appear. Taking its place in the air above the larger bird, the kingbird maintains the relative position and, with a note of alarm, now and again dives swiftly down and stabs the offender with his sharp beak. Neither Crows nor Hawks make any attempt at defence, but fly from the assaults of their tiny enemy.

Although the common name, Bee-Martin, is applied to the Kingbird because of the farmers' belief that it preys upon bees, many authorities claim that only the drones are eaten. But as to this there seems to be some doubt.

The general colouring of the Kingbird is greyishslate above, the tail black, slightly tipped with white. Both male and female have an orange-red crest, which is only visible when the feathers are raised.

The Phobe is distinguished by a dark crest on the 
head, white on the outer tail-feathers, yellowish-white under parts, and black bill. This bird is fond of nesting near houses, showing little fear of man. Its name is derived from its monotonous note. The Phoebe is the only member of its family found in numbers in the Southern States during the winter.

The Wood Pewee is a slightly smaller bird than the preceding. The colouring is generally dull dark olive, and the wings have two whitish bars. The upper mandible only is black. The wings are considerably longer than the tail, as in one other species, the Olivesided Flycatcher, and the legs are short. The Wood Pewee nests on the limbs of trees, from twenty to thirty feet above the ground, and the nest, like that of the Humming-bird, is hardly to be distinguished from the bough on which it rests.

The Great Crested Flycatcher is the largest of this family, being slightly more than nine inches in length. The upper parts of the body are greyish-brown, with tints of olive green; the throat and breast are pearlgrey, the rest of the under parts bright yellow. A peculiar habit of this bird is the lining of its nest with a cast snake-skin, for what reason is not known. The Crested Flycatcher is a shy bird, keeping well out of sight, and its habits are not so well known as those of some other members of its family.

\section{SUb-order-Oscines}

We pass now to the second of our two great groups of Passerine birds. This group, which is divisible into two sections, is made up of what are known as the 

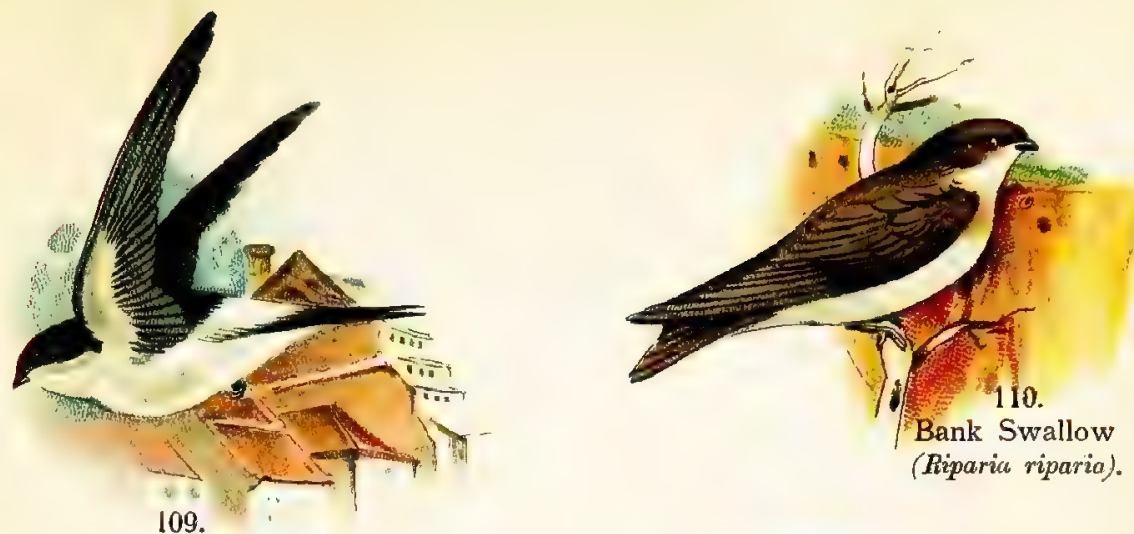

European House Martin

(Ohelidonaria urbica).
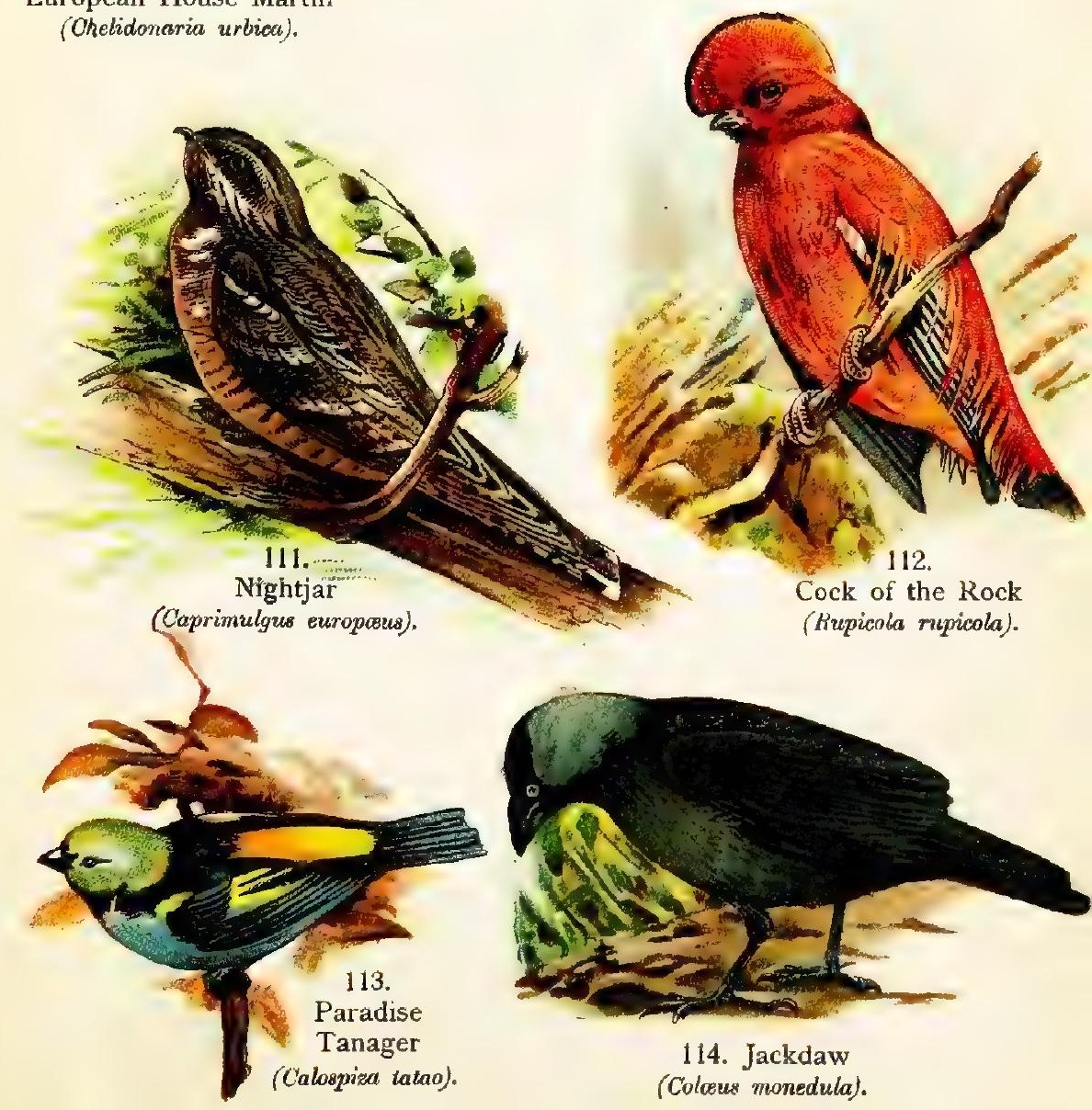

114. Jackdaw

(Colous monedula). 

Oscinine Passeres, or Oscines, which are distinguished by having the voice-muscles inserted into the ends of the windpipe. Strange to say, though all the birds included in the second section should prove fine songsters, only a few are really good performers. Crows, for example, are deficient as singing birds, yet they have the same voice-organ as the Nightingale. But then, even in the human race, the voice-muscles of those who are tuneless do not differ essentially from those of the greatest singers.

The curiously aberrant type known as the Lyrebird represents the first of the two sections just referred to: By most authorities this bird is placed apart from the true Oscines, and made to form a subgroup, or section, because its voice-muscles, though resembling those of the "true Oscines," are not the same in number; but for our purpose this distinction may be ignored. The Lyre-bird is a native of Australia. Three species are known, that which forms the subject of our illustration being found in New South Wales. See Plate 14, Fig. 73.

These birds are remarkable for the peculiar form of the tail, the two outer feathers of which are of great length, and so curved as to form a general resemblance to the old-fashioned musical instrument known as the lyre--hence the name of the bird. The inner tailfeathers have a peculiar structure, and a soft and filmy appearance.

One authority says: "These birds inhabit precipitous sandy gullies in thick forests with tangled undergrowth. Each cock has a walk, or playground, and scrapes little hillocks, or hollows, for dancing 
places, where he struts or pirouettes with erect tail and drooping wings, scratching, pecking, and singing at intervals. The normal cry is a loud, liquid gurgling sound; but they are clever mockers, imitating a cock's crow, a hen's cackle, a dog's bark or howl, the Laughing Jackass's note, or even the setting of a saw." They lay but one egg, in a bulky nest of sticks, lined with moss and feathers, and placed either in the fork of a tree or on the ground. The nestling is remarkable for the fact that it is covered with long and woolly down-a feature shared by no other Passerine bird.

All the birds now left for consideration here belong to the second section, and are commonly called the true Oscines, having from five to seven pairs of singing-muscles.

These will be described in order, as nearly as possible, according to their grade of evolution. That is, we shall begin with those species which are apparently least specialised, least modified, and proceed to those which are most specialised, or modified.

\section{Swallows}

According to this plan, we commence with the Swallow tribe. There are many species of these birds, widely distributed throughout the world. All have long, slender, but powerful wings, and very weak feet, showing that much of their life is spent in flight and that the feet have become feeble from disuse. In many species the tail is forked. They feed almost entirely upon insects, captured in the air, their deeply 
cleft mouths, like those of the Goatsuckers, being well adapted to the purpose. The bill is very short, and slightly curved at the tip. Swallows have a very beautiful flight, unlike that of any other bird. They are gregarious, and just before migrating in the fall, assemble in enormous numbers. Swallows lend much charm to the life of the country during the summer months, and they are certainly most useful birds from an economic standpoint. Like its relative, the HouseMartin, the Swallow builds a nest of mud, on rafters in barns and outhouses, and sometimes in trees. Two broods are usually reared before the summer is over. The species figured is the Common Barn Swallow of Europe. See Plate 18, Fig. 108.

The House-Martin may easily be distinguished from the Swallow, having a large patch of white on the lower part of the back, and the under parts all white. Besides this, the Martin has legs and toes completely covered with short, downy feathers. This bird usually builds its nest under the eaves of houses, and lays white eggs, while those of the true Swallow are spotted. The House-Martin is not represented in this country. See Plate 19, Fig. 109.

The Bank Swallow is a small form corresponding to the Sand Martin of Europe, a dull greyish-brown above and white below. Unlike the Swallow and the Martin, it nests in holes in sandbanks, laboriously tunnelling long chambers in which the eggs are deposited, from two to three feet from the entrance. And this work is accomplished by means of the feeblest of beaks and feet. See Plate 19, Fig. 110.

This species is very similar to the Rough-wing 
Swallow, which also usually, though not invariably, nests in sandbanks.

The Purple Martin is the largest member of this tribe in North America. The male is a beautiful glossy, bluish-purple colour over the entire body, darkening on wings and tail, while the female is a duller hue above and greyish-white below. This bird is quite common throughout the Southern States, where it is valued for its usefulness as well as for its beauty and sweet song.

Two other species of Swallow common in America are the Cliff Swallow, distinguished by its reddish upper tail-coverts and bluish-black back striped with white, and the Tree Swallow, all blue above and white below. The former builds nests of mud in cliffs or under the eaves of houses and barns, while the latter nests in trees or in boxes provided for its use.

\section{European Flycatchers}

The European Flycatchers are included among the true Oscines, or singing birds, and rank next in order to the Swallows.

The two best known species are the Pied and the Spotted Flycatchers, both of which are common on the continent of Europe and in the British Islands. In general characteristics they resemble their American cousins, preying upon insects which they capture in the same manner. See Plate 10, Fig. 4\%.

The general colouring of the Spotted Flycatcher is light brown, darkening on wings and tail, throat and breast paler and streaked with brown. This bird 
builds its nest on the branch of a tree, while the Pied Flycatcher makes use of the hollows in trees.

\section{Shrikes}

The Flycatchers are comparatively feeble birds, but their near relatives, the Shrikes, or Butcher-birds, are much more formidable. They are considerably larger, and are distinguished by their almost Hawklike beaks, which are used to tear living prey, such as smaller birds, mice, and so on. Although numbering about two hundred species, these are mostly confined to the Old World, only two being native to America.

The first of these is the Northern Shrike, a rather large bird, measuring over ten inches in length, grey upon the upper parts, with black wings and tail, marked with white. The bill is powerful and hooked like that of a Hawk. This bird has a characteristic straightforward flight, flying close to the ground with much flapping of the wings, and rising suddenly upward to perch.

The Northern Shrike breeds in the far north, migrating southward in winter. Its nest of twigs and grass is usually placed in low trees or bushes. The Great Grey Shrike of Europe closely corresponds to this species. See Plate 10, Fig. 46.

All the birds of this family have the curious habit of killing and impaling their prey on thorns and twigs, presumably for future use. It is on this account they have received the name Butcher-birds. The English name, Flesher, comes from an old English word for butcher. Preying as it does upon 
many harmful insects and mammals, and especially upon the noxious English Sparrow, ornithologists declare that this bird well deserves to be protected.

The Red-backed Shrike is another common European species. See Plate 10, Fig. 45.

The Loggerhead Shrike is a smaller form than the northern species, but closely resembles it in colouring. This bird does not fly forth in search of prey, but, like the Flycatchers, perches and waits for it to come within view. Its power of sight is remarkably keen, and the grasshoppers, small snakes, and lizards upon which it chiefly feeds are detected at long distances. This bird also often impales its victims on thorns, capturing more than it can devour at one time. The Loggerhead's notes are harsh and guttural, unlike those of the Northern Shrike, some of whose notes are very musical.

\section{Titmice}

The Titmice are small birds, of rather pugnacious disposition, and commonly known in this country as Chickadees. It is a moot point among ornithologists as to whether or not they are related to the Shrike family. These little birds feed largely on the eggs and larvæ of insects that are injurious to trees, and so are of great benefit to man. They have short, stout bills, and the nostrils are concealed by bristles.

A common English species is the Blue Tit, a courageous little bird, especially during the time that it is sitting on its eggs. The nest is usually made in the hole of a tree-trunk, sometimes in deserted Woodpeckers' holes, from which intruding fingers are often 


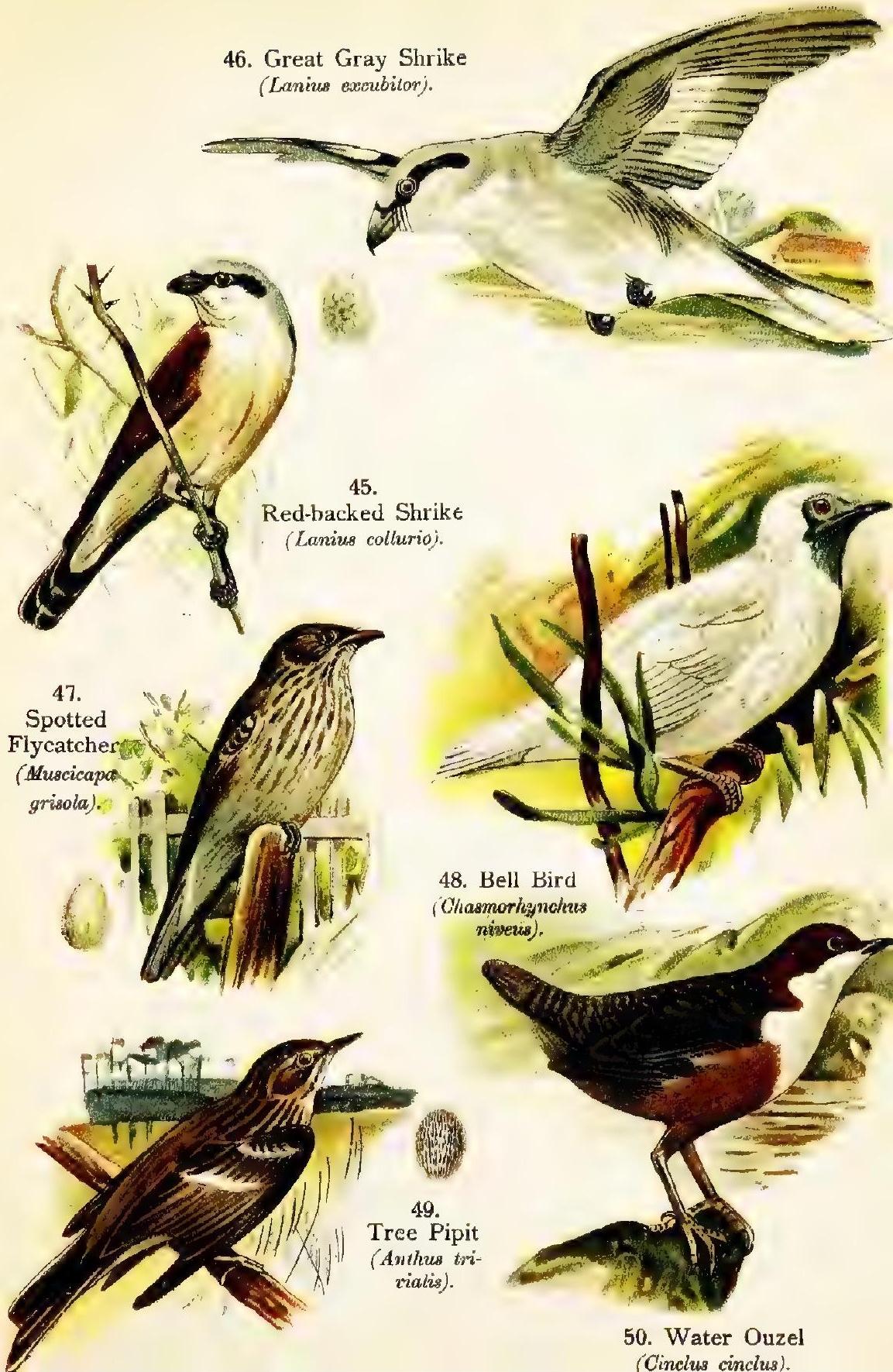



hastily withdrawn in consequence of a hissing sound from the bird, resembling the warning note of a snake. This bird may be readily induced to take up a residence in any desired spot by means of nesting-boxes hung in convenient situations. See Plate 15, Fig. 83.

The Great Tit is a larger bird than the preceding, but similar in appearance. It may readily be distinguished, however, by the broad black stripe which runs down the middle of the breast. The Great Tit frequently attacks smaller birds, beating out their brains with its powerful beak. See Plate 15, Fig. 84 .

The Coal Tit and the Crested Tit require to be carefully sought, being of shy and retiring disposition. The Coal Tit is met with in many of the less populated districts throughout the British Islands, but the other species mentioned is rarely seen except in Scotland. See Plate 15, Figs. 80, 82.

While Titmice are mainly insect-feeders, ripe pears and apples prove an irresistible attraction, especially for the Blue Tit, and on this account it is disliked by fruit-growers. In spite of its depredations, however, it is a most useful bird.

The Long-tailed Tit is the smallest of the family, and a very handsome little bird. In the art of nestbuilding it is most skilful. Oval in shape, the nest is covered on the outside with moss and lichens, and lined with feathers. It is suspended from a branch usually not far from the ground, and harmonises so perfectly with its surroundings that even an expert nest-hunter has difficulty in finding it. When sitting, the long tail of the bird is turned over the back, so that beak and tail often poke out of the doorway at the same 
time. The capacity of this nursery is as wonderful as its structure, since as many as sixteen youngsters have been found together inside, though usually the number ranges from seven to ten. See Plate 14, Fig. 78.

The Chickadee is a very common little bird of this family in eastern North America, easily distinguishable by its glossy black cap and throat, white at side of head and neck, white outer webs of wing-feathers, and buffy sides. It nests in holes in stumps and old trees, lining the cavities with feathers, grasses, and so on.

This attractive little bird is not at all shy, and is often seen about houses in the winter months. Feeding chiefly upon insects in summer, in cold weather it will eat seeds, nuts and a variety of other food, when obtainable, showing much adaptability. Another common name for the Chickadee is Black-capped Titmouse.

The Tufted Titmouse is a resident of the eastern part of the United States, where it is widely distributed. The upper parts are, in general, a grey colour, the under parts white, with a reddish tinge on the sides. The forehead is black, and the crest is well marked. Its notes are louder and not so pleasing as those of the Chickadee, and they are uttered almost continuously.

\section{Nuthatches}

These birds are near relatives of the Titmice, and four out of the twenty known species are found in North America. As a rule, the Nuthatches are inconspicuous in colour, black, white, and grey prevailing. They resemble the Woodpeckers, and like 
them, pass their lives on the trunks of trees. The tail differs from that of the Woodpeckers, however, in that the feathers are soft, and not spiny, and therefore it is not used as a support for the body when feeding. The Nuthatch is able to climb up and down the trunks of trees with equal facility. See Plate 21, Fig. 128.

Holes in tree-trunks are generally used as nestingplaces, and at the bottom of the cavity a bed of dry leaves is made on which the eggs are laid. When the entrance is too large, the bird reduces it by the use of mud to the desired size-a hole just large enough to pass through.

This bird receives its name from its habit of wedging nuts in crevices of the bark of trees and hammering, or hatching, them until the shell is broken. During a large part of the year insects form a considerable portion of its diet, and hard seeds of many kinds are also eaten.

The White-breasted Nuthatch is a resident species throughout eastern North America. It closely resembles the European species figured. All the birds of this family are of stocky build, have strong and sharply pointed beaks, sharp claws fitted for climbing and short, square tails. The White-breasted Nuthatch has the crest and forepart of the back glossy black, the rest of the upper parts blue-grey, with some white feathers in wings and tail. It nests in holes in trees, like the Old World species, sometimes excavating them for itself, like the Woodpeckers.

In winter this bird is frequently seen in the eastern part of the United States in company with the Downy 
Woodpecker and the Chickadee. It is easy to identify from its habit of running up and down the trunks of trees, usually in a spiral course, searching for grubs concealed in the bark.

The Red-breasted Nuthatch is a more northern species than the preceding, but is similar in appearance, except for a black stripe which runs through the eye to the back of the head, and for the reddish instead of white breast. Its notes, too, are quite different in tone, and neither species is remarkable for its melodious voice.

\section{Tree-Creepers}

Like the foregoing family, these birds are treedwellers. Like the Nuthatch, the Tree-creeper climbs about the trunks of large trees; but in one point it differs conspicuously - in the form of its tail. In the Nuthatch the tail is short and soft; in the Treecreeper, on the other hand, it is long and composed of stiff and pointed feathers, as in the Woodpecker. Since the Nuthatch uses its beak as a hammer, after the manner of the Woodpecker, and the Tree-creeper does not, this curious difference is not easy to understand, for the Woodpecker's tail is supposed to have developed as a support for the body and to give force to the hammering of the beak. This prop seems to be unnecessary in the Nuthatch. The Tree-creeper's beak, indeed, could never be used hammer-fashion, for it is slender and curved and is used for the capture of insects. See Plate 21, Fig. 127.

The American Brown Creeper is the only one of the twelve recognised species found in America. It cor- 


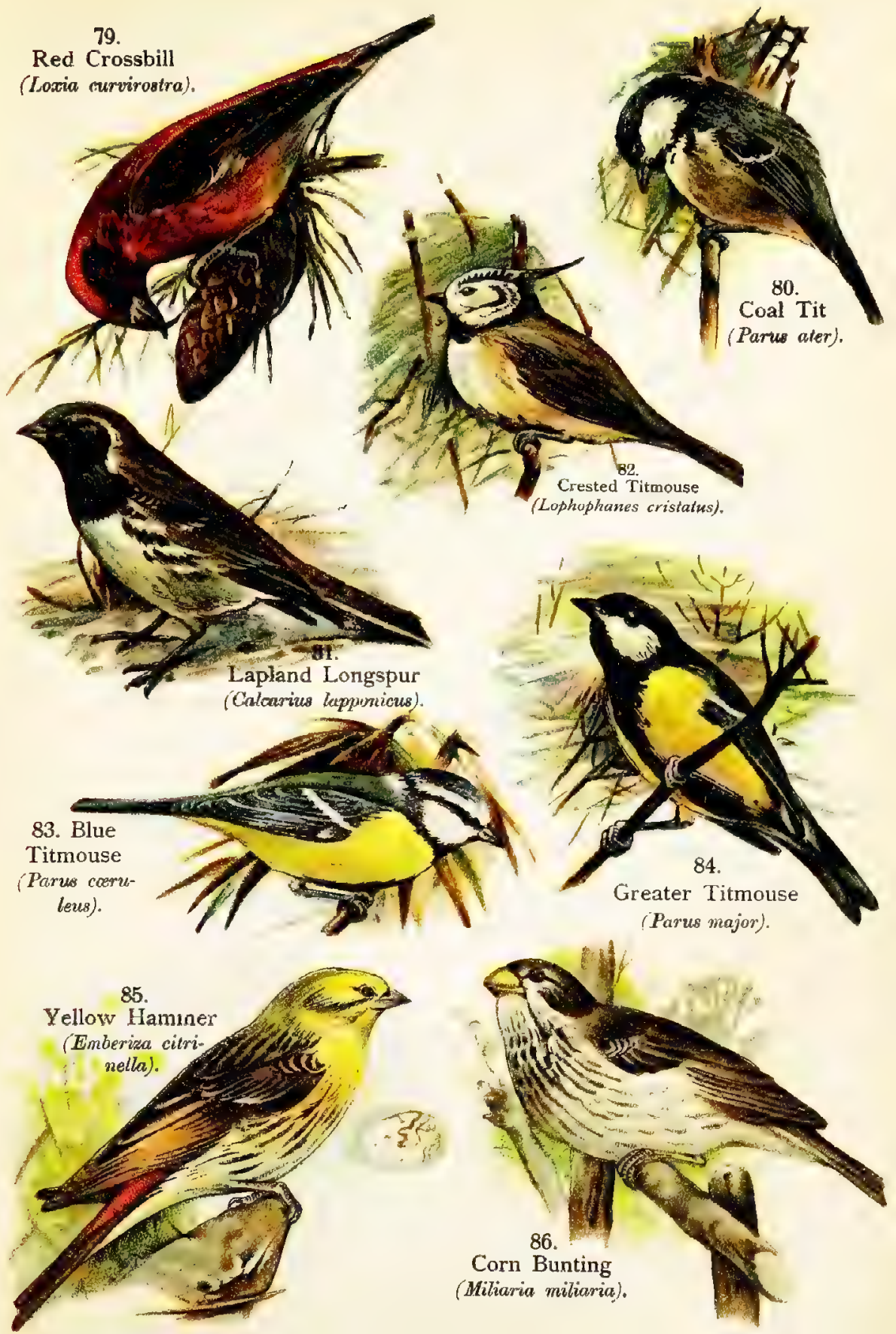



responds to the European form, being black, white and buff above, and white below. It breeds in the North and in winter migrates southward to the Gulf States. Owing to its small size, sober colours and the skill with which it contrives always to keep the trunk of a tree between itself and human observers, this bird is seldom seen. Its faint little twitter, uttered as it climbs about, is very pleasing.

The beautiful little Wall-creeper is found only in Asia and certain parts of Europe. It is of a soft greyish colour, with white spots on the outer tail-feathers and crimson wing-coverts. The appearance of this bird has been noted two or three times in the British Islands. See Plate 21, Fig. 126.

\section{WRENS}

The Wren family includes a great number of very small birds, spread over the greater part of the world, being especially abundant in the New World. They are not found, however, in Africa and the Australian region. They are insect-feeders and therefore migratory in their habits. Wrens are active, nervous birds, with musical voices.

The common American House Wren is found nearly everywhere in North America. The colouring is brownish above, indistinctly barred with darker colour, and greyish below. Like all the other members of this family, it builds domed nests, frequently in outhouses and other places in proximity to human beings. The wings are short and rounded and the short tail is usually carried in a vertical position. 
The Common Wren of Europe closely corresponds to this species. It is popularly known as "Jenny Wren" and is a favourite character in the folk-lore of E.ngland. See Plate 13, Fig. 68.

Other familiar American species are the Winter Wren, the Carolina Wren and the Marsh Wren.

This great family embraces not only the typical Wrens, but the Mocking-birds, the Catbirds and the Thrashers.

Among the song-birds of America the Mockingbird easily takes first place, its wonderful vocal powers being equalled only by those of the celebrated Nightingale of Europe. Not only are its own notes remarkably melodious, but it has the ability to imitate closely the voices of other birds as well as many other sounds in Nature. See Plate 42, Fig. 247.

In colour the Mocking-bird is ashy above, darkening on wings and tail and paling to dingy white below. The lower half of the quill-feathers of the wings is white, and some of the tail-feathers are also marked with white. The sexes are almost undistinguishable in colour, though the male has a little more white in the plumage.

These birds are very common in our southern States. They show little fear of man and are often seen in city streets and parks. Mocking-birds sing morning and evening, and on moonlight nights are frequently heard all night. They build clumsy-looking nests in low trees, not far from the ground, and in thickets, and the eggs are greenish, spotted thickly with brown.

While not equalling the Mocking-bird in musical 
ability, its near relative, the Catbird, yet has a charming song of its own, as well as considerable power of mimicry. It is bluish-grey above, with crown and tail black and under tail-coverts brownish red, sometimes spotted with slate colour. This bird is of a lively and active disposition and very friendly and intelligent. One of its commonest notes resembles the mewing of a cat, and from this it derives its name.

The Catbird is very abundant in the eastern part of the United States, breeding from the Gulf States to Canada. It makes a coarse nest of twigs, leaves, and so on, and lays greenish-blue eggs.

Another well-known American member of this family is the Brown Thrasher, a frequenter of undergrowth and thickets, especially in the Southern States. The upper parts are a rich reddish brown, the under parts whitish, heavily streaked with dark brown, except on the throat and middle of the breast. The wing-coverts are tipped with white. The Brown Thrasher in form closely resembles the Mocking-bird, and, like it, has the ability to mimic other birds. Its own song, heard during the breeding season only, is loud and very melodious, and is repeated for a long time.

\section{W AXWINGS}

A very remarkable family is that which comprises the Waxwings of North America and northern Europe and Asia. Numbering but few species and of uncertain lineage, the birds of this family have acquired notoriety on account of the fact that the inner wing-quills and tail-feathers are tipped with horny 
plates, having the appearance of small drops of red sealing-wax.

The Waxwing, or Bohemian Chatterer, is an inhabitant of the Arctic regions. It is very rarely seen in the Atlantic States, but more often in the northern part of the interior of the United States. It has visited the British Islands periodically for upwards of two centuries, sometimes in great numbers. See Plate 18, Fig. 106.

The Cedar Waxwing is a much more common species in this country, breeding from Virginia northward. The upper parts in this bird are greyish, the forehead, chin, and a line through the eye black. The tail is yellow at the end, and the secondaries and sometimes the tail have the small wax-like tips that give the name to the species. It is slightly smaller than the preceding form, but, like it, has a conspicuous crest. Mrs. Bailey says: "The squads of Cedar-birds fly evenly on a level with the tree-tops, in close ranks often of five, seven or nine. Frequently, when under full headway, they suddenly wheel and dive down to an apple-tree for a meal of canker-worms."

\section{OrIOLES}

The true Orioles are an Old World family exclusively, and as to their exact relationship, there is some difference of opinion among naturalists. In the young the under parts are streaked in a way that is thought to ally the group with the Starlings.

The Golden Oriole is one of the most beautiful of birds, the body plumage being bright yellow, with black wings and tail. The female is more soberly col- 
oured-dull green above, the under parts streaked with grey. This species winters in Africa, migrating to southern and central Europe in the spring, and occasionally breeding in the British Islands. All the family have sweet, flute-like voices. See Plate 11, Fig. 51.

The nest of the Golden Oriole is a very cleverly made, cradle-like structure of bark, wool, and grassstems, woven together and suspended beneath the fork of a small branch of a tree.

The American family is a large one, embracing a hundred and fifty species, or more, most of which make their home in the tropics. They differ structurally from the Old World Orioles, as well as in many of their habits, but, like them, feed upon insects, fruit, and seeds. They are found in widely different localities, frequenting woodlands, plains, and marshes, showing much adaptability to environment. Certain species are fine singers, while others have harsh and disagreeable voices.

The most conspicuous member of the family is the Baltimore Oriole, found quite abundantly throughout eastern North America. The head, throat, upper part of the back, and middle tail-feathers are black, some of the wing-feathers are edged with white, and the rest of the plumage is a rich orange colour.

Like the Old World Oriole, this bird builds a suspended nest of grasses, bark, hair, and so on, near the end of a small branch. The work of constructing the nest seems to be done by the female, the male bird assisting her by bringing some of the material used. 
The eggs are whitish, with irregular dark lines and a few spots.

One of our best known American song-birds is the Bobolink, Reed-bird or Rice-bird. The male of this species has two distinct phases of plumage. In the breeding season, the head, throat, and under parts of wings, and tail, are black, the fore part of the back buffy, the scapulars and upper tail-coverts dingy white. In the fall, after the breeding season, these feathers are all moulted, and the Bobolink assumes the streaked olive and buff colours of the female and young. At this time, during their migration to South America, these birds stop on their way to visit the rice. fields of the Southern States, gorging themselves with the rice until they become very fat. When in this condition they are esteemed a great delicacy and are shot in large numbers to supply the table.

The Bobolink has a rich, melodious voice. His song has been described as "an irrepressible outburst; a flood of melody from a heart overflowing with the joy of early summer."

Another very common bird of this country is the Red-winged Blackbird. Its name is taken from the colour of its lesser wing-coverts, which are a bright crimson, showing conspicuously in flight, but not visible when the wing is closed. The middle wingcoverts are yellowish, all the rest of the plumage is glossy black. The colouring of the female is much like that of a common Sparrow.

This bird breeds from the Gulf of Mexico to Canada, and winters southward from Virginia. Its nest is built in bushes and reeds in swampy ground. 
The Cowbird has fittingly been called an outcast among the feathered tribe, on account of its despicable habit of shirking the duties of parenthood and foisting the care of its offspring upon other birds. Like the Old World Cuckoo, the Cowbird watches its opportunity to deposit its egg in the nest of some smaller bird, who usually cares for it in preference to her own eggs and young, though the imposition is sometimes detected and the Cowbird's egg thrown from the nest.

The plumage of this bird is shining black, with a metallic lustre over the greater part of the body. The head and neck are dark brown.

The Purple Grackle, or Crow Blackbird, has beautifully iridescent plumage of green, blue and black, over the entire body, somewhat duller below than above. This bird breeds in the eastern part of the United States, wintering in the southern part. A noticeable feature in all the Grackles is their bright yellow eyes, which contrast strikingly with their sombre plumage. These birds are said to prey upon the eggs and young of other species. Their notes are harsh and disagreeable.

A much larger form than the preceding, found principally in the marshes of Florida, is the Boattailed Grackle, the general colour of which is bluish or purplish-black, darker on wings and tail.

The Meadowlark is the most soberly coloured member of this family, the plumage being a mixture of black, buff and white. The outer tail-feathers are white, forming a conspicuous mark when the bird is on the wing. These birds frequent marshes and meadow-lands, where they blend so well with their 
surroundings that they are able to keep themselves well out of sight.

\section{Starlings}

The Common Starling belongs to a family that is peculiar to the Old World. These birds seem to be most nearly related to the Golden Oriole, as already mentioned. The Starling is an extremely beautiful bird, its plumage, purplish and greenish in general tone, having a wonderful metallic lustre. The new feathers, assumed after the autumn moult, have light buff tips, which gradually wear off as the summer livery is gained. See Plate 20, Fig. 120.

These birds lay their eggs in holes or the hollow trunks of trees, making but little pretence at nestbuilding. Young Starlings are of an ash-brown colour, totally unlike that of the adult birds.

The Starling has been introduced into this country in recent years, where it breeds well and seems to have become completely naturalised. Like the English Sparrow, it is combative in disposition, and is said to be driving away some of our native birds.

\section{DIPPERS}

The birds of this family enjoy the unique distinction among perching birds of being not only able to swim, but also to run or fly along the beds of swift streams. The Dipper, or Ouzel, is like a large Wren in appearance, having a stout body and a very short tail. The upper parts are dark brown, and the breast white. It receives its name from the habit of dipping or ducking in the water. The Dipper is an insect-feeder, though 
it has been accused of devouring the eggs of trout in mountain streams. The case, however, has never been proved against them. See Plate 10, Fig. 50.

The American Dipper, or Water-ouzel, as it is frequently called, resembles the European, but the breast is dark-coloured instead of white. About twelve species are known, all found in the neighbourhood of mountain streams. They build round nests of moss, on the ground, and their eggs are white.

Of this bird Elliott Coues writes: "Although not web-footed, nor able to swim with its feet, nor having the slightest affinity with water birds, nevertheless there is no duck nor diver more truly aquatic than the Dipper; a great part of its time, in fact, being spent under water, where it repairs in search of food."

\section{Thrushes}

We pass now to the large family of Thrushes and their near relations, many of whom are superb songsters. These birds are spread over a large part of the globe, about twelve, out of the three hundred or more species, being found in the United States. They are rather stoutly built, live in wooded districts, and feed largely upon insects and fruit. The sexes are much alike in colouring, and the species are migratory and somewhat gregarious in habit. The true Thrushes are generally brownish or olive above, with light breasts spotted with darker colour.

The Missel-thrush is the largest song-bird found in the British Islands, where it is seen all the year round. It measures about ten and a half inches in length, and is distinguished by the fact that the spots on the breast 
are kidney-shaped, while in the Common European Thrush they have somewhat the shape of a peg-top. The outer tail-feathers are tipped with white. See Plate 11, Fig. 55.

The European Blackbird is probably a better known bird than the preceding, for he is more in evidence, living in and near large towns. In the London parks Blackbirds are seen at all seasons of the year. Though the sable livery and golden bill give this bird some claim to beauty, it is more as a songster that it is esteemed, its notes being peculiarly flute-like and beautiful. The plumage of the female is dull brown.

It is interesting to note that the nest of this Blackbird, like that of the Missel-thrush, is lined with dry grasses, while that of the Common Thrush has a water-tight lining of rotten wood. See Plate 11, Fig. 54.

Nearly related to, and more striking in appearance than the Blackbird, is the Ring-ouzel, which has a pure white crescent on the breast. As a songster, however, it is far inferior to the other species. See Plate 11, Fig. 56.

A very beautiful European Thrush is the Rockthrush, which most nearly represents the American Bluebird. The plumage of the male is a mixture of blue, black, white and reddish colours. This bird is common in Germany and other parts of the continent of Europe, but is seldom seen in Great Britain. See Plate 12, Fig. 57.

The delicately coloured little bird called the Wheatear is found widely distributed throughout the Old World, and occasionally visits America. The plumage 


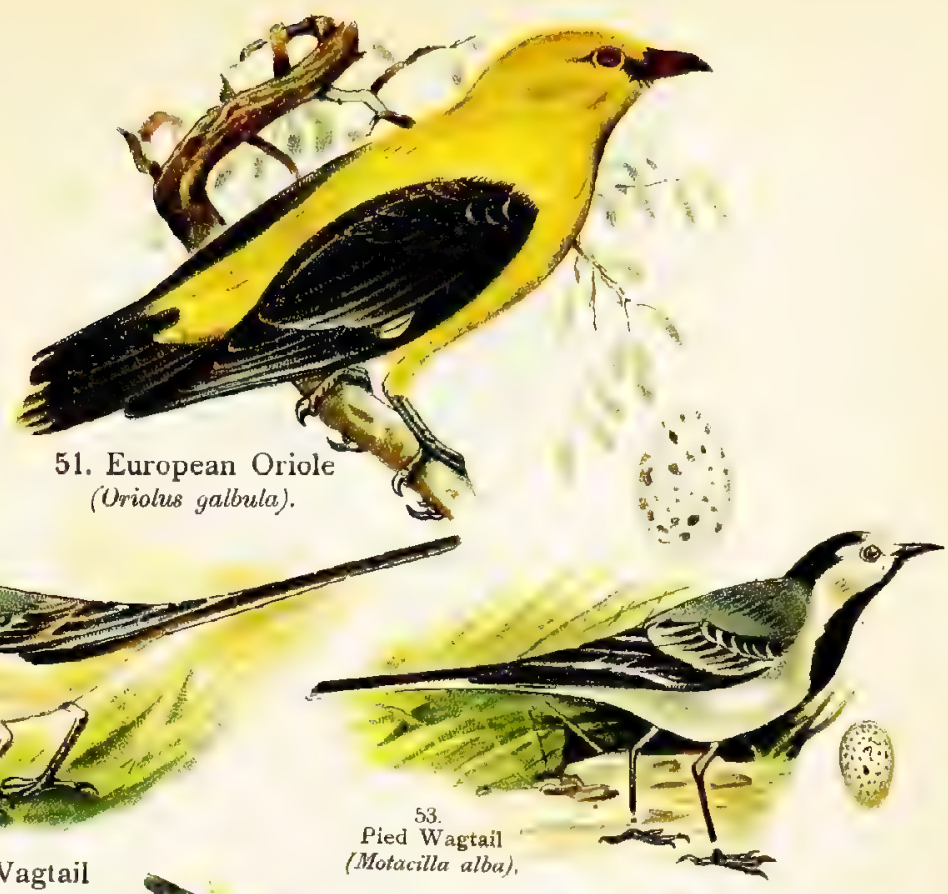

52. Gray Wagtail (Motacilla melanope).

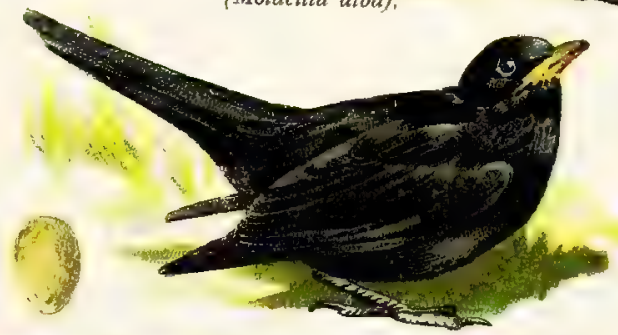

54. Blackbird

(Merula merula).

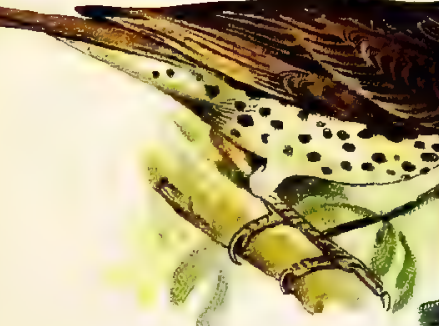

55. Missel Thrush

(Turdus viscivorus).

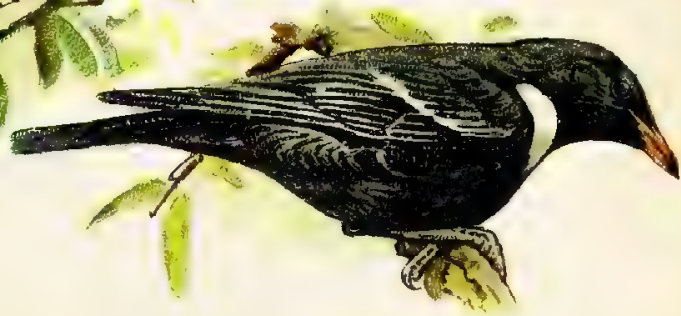

56. Ring Ouzel (Merula torquatus). 

of the male varies with the season. In summer it is a pale grey above, with wings and tail black, the rump and base of the tail white, and the under parts whitish. After the autumn moult he assumes a plumage that closely resembles that of the female, the feathers having long brown fringes, which wear off as spring approaches. The female is dull brown above, and the young are similar in colouring, but are slightly spotted. The name "Wheatear" comes from an old Saxon word. "Wheat" is a corruption of white, and "ear" is from the old word "aers," meaning rump, in allusion to the white patch above the tail. See Plate 12, Fig. 60.

An extremely lively and very pretty member of the Thrush tribe is the Stonechat, common throughout the whole of Europe, and especially abundant in the pasture-lands of Eugland. It is an insect-eater, and feeds largely upon the destructive wire-worm. The Stonechat builds a nest of grass and moss on the ground, or in the stems of bushes but a few inches from the ground. See Plate 12, Fig. 62.

A near relative of the preceding form is the European Redstart, of which two species are figured, the Common Redstart and the Black Redstart. Both are extremely handsome little birds, and fairly common in the Old World. They are said to be increasing in Great Britain and extending their range. Curiously enough, the eggs of the two species differ conspicuously, those of the Black Redstart being a pure, shining white, while those of its relative are a beautiful pale blue. The Redstarts build nests of fine grass and 
moss, hidden away in holes of trees and buildings, or in clefts of rock. See Plate 13, Figs. 65, 66.

A no less beautiful bird is the Blue-throat, of which there are two-perhaps three-forms found in European countries. The first has a red spot in the middle of the blue throat; the second a white spot. A third, unspotted form may be but a variety of the whitespotted species. The red-spotted Bluethroat is a bird of high northern latitudes, where its song enlivens the nightless Arctic summer and rivals that of the Nightingale in richness. The white-spotted bird breeds south of the Baltic Sea. See Plate 12, Fig. 63.

Probably the English Redbreast, or Robin, holds chief place in the long roll of British birds, on account of its friendly ways and sweet notes. It is a small bird, about five and a half inches in length, olive-green above, throat and fore part of the breast orange-red. This bird is found even in large cities, in the parks and gardens. The males and females are alike in colouring, but the first plumage of the young birds is a dull brown, showing no trace of the orange-red throat so conspicuous in the parents. They are often mistaken for the females of the species. See Plate 12, Fig. 61.

While it is not true to say that no brightly coloured birds sing well, it is a well-known fact that some of the most soberly clad are the sweetest of all the songsters. This is peculiarly true of the Nightingale, whose wonderful melody is celebrated throughout the world. This bird is found in many parts of the Old World, and is very common in Great Britain. The sexes are coloured alike, reddish-brown above and whitish below. See Plate 12, Fig. 59. 
The American Robin, or Migratory Thrush, is one of the most familiar of our birds, being found throughout the whole of North America. The name "Robin," or "Redbreast," was given it by the early English settlers in this country, on account of its resemblance to the Old World bird called by that name. The Robin of the New World, however, is a much larger form, being nearly twice the size of its European cousin, and the red breast is different in hue. It is slate-colour above, the head is black, and the throat is streaked with white. The food of the Robin consists of worms, insects, and fruit. The foundation of the nest is made of mud, lined with grasses and other soft materials. The song and call-notes of this bird are very varied, expressing suspicion, alarm, caution, and so on, and many of them have never been satisfactorily interpreted.

The Bluebird is another well-known American member of the Thrush family, whose arrival in the spring is eagerly looked forward to. It is a resident species throughout eastern North America, though the majority of Bluebirds go South for the winter. The general colouring of the upper parts is brilliant blue, darkening on the wings; dull reddish on the breast, the rest of the under parts whitish. The young are spotted on breast and back.

The largest member of the Thrush family in America is the Wood Thrush, reddish-brown above, changing to olive-brown on the tail. Except on the throat and down the middle, the under parts are thickly spotted with black, the spots reaching well up under the wings. This bird is common in the Eastern States. 
Its notes are very sweet and flute-like in quality. The nest and the eggs are much like those of the Robin.

Wilson's Thrush, or Veery, is a duller brown than the Wood Thrush, and has the under parts white, flecked with small wedge-shaped spots, much the same colour as the brown of the back. The song of this bird is peculiar, and unlike that of any of the other Thrushes.

The Hermit Thrush is spread over nearly the whole of North America. It is olive-brown, shading to reddish on the tail; throat and breast buffy, profusely spotted with dark brown. This bird, like the other members of the group, is a fine singer. While not especially shy, the Hermit Thrush is not very often seen, from the fact that it inhabits woodlands and thickets, rather than open country. It builds a nest of sticks and twigs, on or near the ground, and the eggs are greenish-blue, like those of the Robin and Wood Thrush. See Plate 42, Fig. 248.

\section{W ARBLERS}

This is a very large group of birds, inhabiting both the Old and the New World, embracing several families and many different species. Only a few birds in America correspond to the Warblers of the Old World, all of which, unlike the typical American family, have clear, sweet voices. A few species representative of the Warblers of both countries will be briefly mentioned. They are active, sprightly little birds, more or less green or brown above, and yellow or buff below. Formerly they were included in the Thrush 

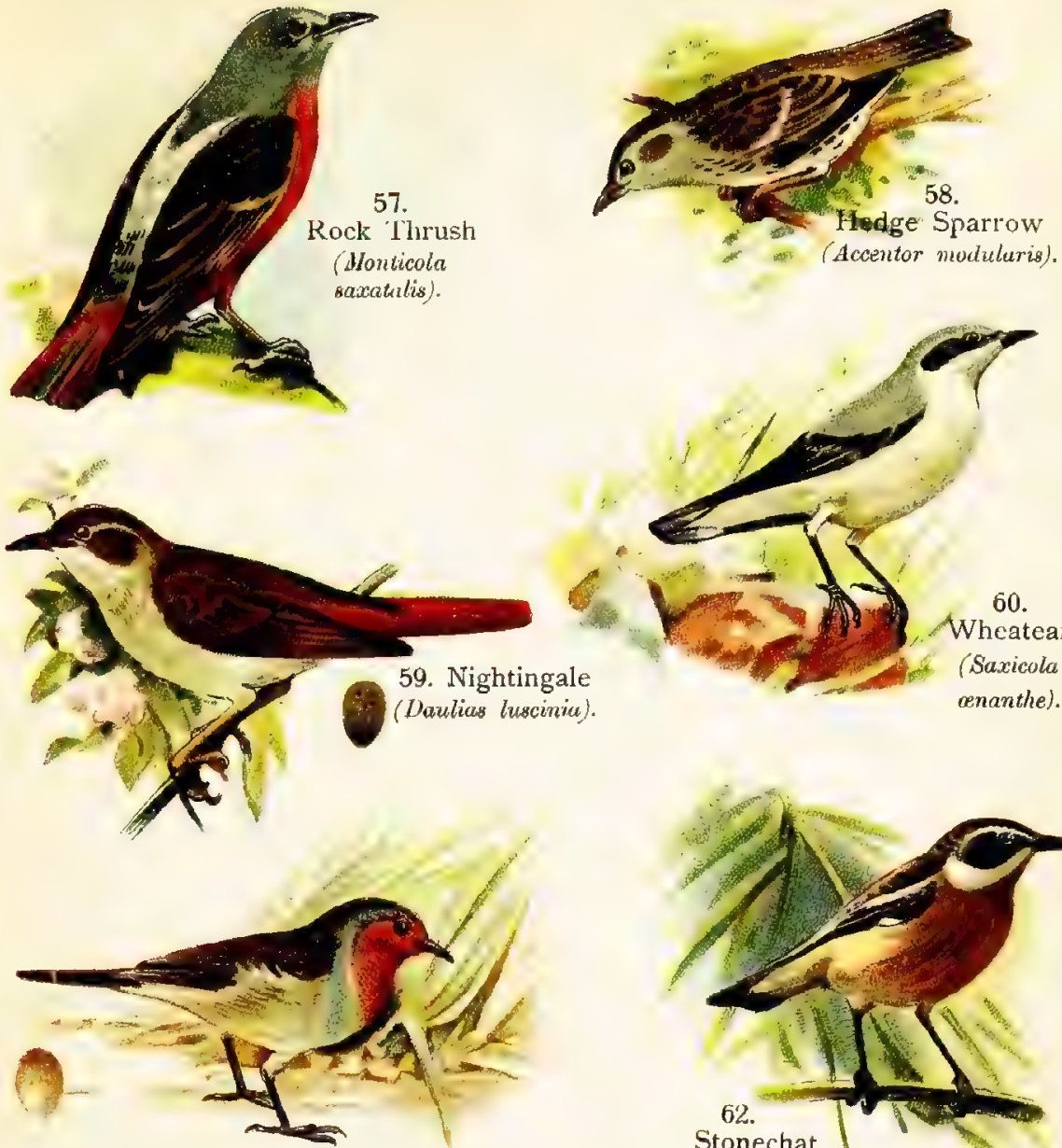

61. European Robin Redbreast

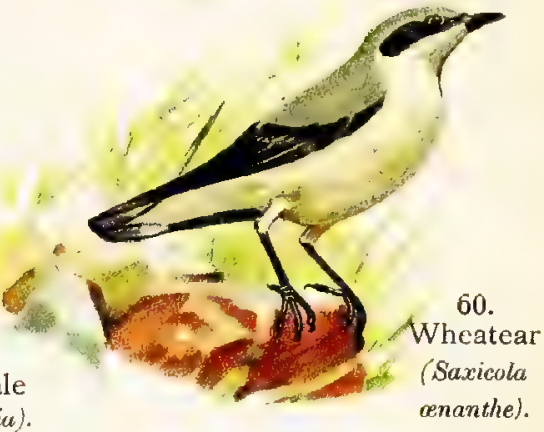

(Erythacus rubeoula).
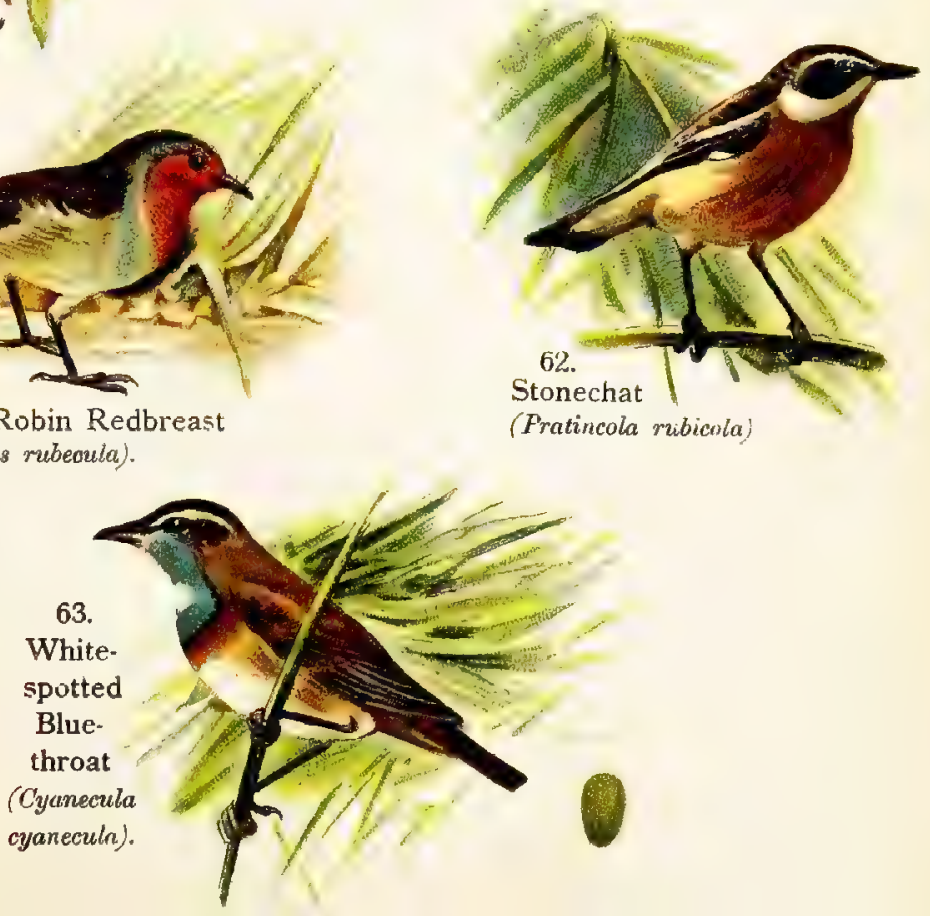

family, from which they have now been separated on account of certain important differences. The Warblers have two moults during the year, and the young are like the parents in colour.

The Blackcap is in some respects almost as skilled a performer as the Nightingale, and it is much more widely distributed than that famous songster. The female Blackcap has the crown of the head a dull chestnut, and so also have the young in their first plumage. See Plate 13, Fig. 72.

Another sweet singer, but far inferior to the Nightingale and Blackcap, is the Whitethroat, a common bird in the British Islands. The male White-throat displays great courage in defense of his nest and young. When an intruder draws near, he flits from branch to branch, with every feather of his crest and throat erect, and tail widely spread, while every now and then he shoots up into the air and descends again, almost vertically, keeping, up this scolding remonstrance until the danger is past. See Plate 13, Fig. 71 .

The Golden-crested Wren has the distinction of being the smallest of European birds, measuring not more than three and a half inches in length. Its nest is a wonderful structure of moss, felted together by spider-webs and sheep's wool. Outside, bits of lichen are fastened to render it inconspicuous, and the inside is lined with feathers. This exquisite little nursery is swung at the. end of a long bough, instead of being placed on it. From five to eight, or even ten, tiny, buff-white eggs, faintly freckled with red, are laid, and most jealously brooded by the female. The young 
birds lack the beautiful golden crest of their parents. See Plate 13, Fig. 69.

The Golden-crowned Kinglet takes the place of the preceding species in America. This pretty little bird has a crown of bright orange colour, bordered by black and yellow. The general tint of the upper part of the body is greyish-green, the lower part whitish. This bird is often associated in migration with another species, the Ruby-crowned Kinglet, which has a bright red crown, more or less concealed, but otherwise closely resembles it. Like the European species, these birds build, elaborate nests, which they suspend from the end of branches-usually from evergreen trees. The song of the Ruby-crowned Kinglet is mellow and flute-like, that of its Golden-crowned cousin shriller and not so pleasing to the ear.

Among the common Old World species figured are the Wood-wren, the Marsh-warbler, and the Icterine Warbler, whose relatives are the Sedge- and Reedwarblers, and the Chiff-chaff. The Reed-warbler builds a most interesting nest. It is shaped like a deep cup, and is fixed at the sides to the tall stems of reeds, giving them the appearance of growing up through the nest. So skilfully is this nursery built, that when the reeds bend low over the water, the eggs or young rest securely at the bottom of the nest. See Plate 13, Figs. 64, 67, 70.

Though many of the Warblers, such as the Sedge-, Reed- and Marsh-warblers, show a preference for swamps and inland water, a great number of species, on the other hand, inhabit dry localities. Between 
some of these species there is so great a resemblance that only an expert can distinguish them.

The Hedge-sparrow is a true Warbler, and is in no way related to the House-sparrow, as the name seems to imply. In their habits, even more than in their appearance, the birds are unlike, for the House-sparrow is mischievous and insolent in demeanour, while the Hedge-sparrow is among the most retiring of birds. It is generally distributed throughout the British Islands, where it is a resident species. This bird is frequently made the dupe of the Cuckoo, performing the work of foster-parent with great zeal. The nest of the Hedge-sparrow, seldom placed far from the ground, is made of roots and mosses, and lined with hair and wool. From four to six beautiful turquoise-blue eggs are laid. See Plate 12, Fig. 58.

As has been said, the Wood Warblers are a peculiarly American family, found chiefly in the eastern part of the country. The greater part of the one hundred known species inhabit the United States, although some are confined to the tropies. They are generally tree-living birds, but a few species are to be found in undergrowth and open country. All are insect-feeders, but vary in their methods of obtaining their prey, some capturing it on the wing, while others find it by creeping about the trunks and limbs of trees.

One of the most beautiful members of this family is the little American Redstart, whose plumage is a charming mixture of shining black and rich salmon colour. It breeds in North America, but winters in the tropics. 
In the Hooded Warbler the hind head, neck and throat are black, the face and under parts bright yellow; back, tail and wings, olive-green. The outer tailfeathers are mostly white, showing conspicuously when the bird is on the wing. Both this and the preceding species have sweet singing notes, and a sharp call when alarmed.

The Myrtle Warbler has the top of head, each side of the breast and the rump, yellow, forming a striking contrast to the black-streaked bluish-grey of the upper parts. The throat is white, and there is much black on the breast. Like the other species mentioned, this bird is common in the eastern part of the United States, and the yellow patches of colour make it easy to identify.

The name of the Blue-winged Warbler is apt to be misleading, since the wings are rather slate-coloured than blue. The tail is the same shade as the wings; the upper parts are olive-green, faintly washed with yellow, and the entire under parts are brilliant yellow. As in many of the Warblers, the wing-coverts are tipped with white, and there are patches of white on the outer tail-feathers. The black line through the eye helps to identify the species.

The black forehead and cheeks, olive-green back, bright yellow throat and breast of the Maryland Yellow-throat, are found in so many other species of the "Yellow-throats" that only an expert ornithologist can distinguish them one from another. The Northern Yellow-throat is a somewhat larger form, found quite widely distributed throughout the northern and eastern parts of North America. 


\section{YELLOW-BREASTED CHAT-VIREOS 205}

A distinguishing field-mark of the Parula Warbler is the triangular patch of greenish-yellow on the fore part of the back. The throat and breast are yellow, and there is a dark band across the breast, usually blackish or reddish. The Northern Parula has a wider breast-band, and there is more reddish in the plumage.

The Chestnut-sided Warbler has reddish-brown sides, greenish-yellow back streaked with black, black on cheeks and sides of throat. This bird is found along the borders of woodlands and in scrubby undergrowth, and its markings differ considerably from those of other species, so that it is comparatively easy to recognise.

The Yellow-breasted Chat has the distinction of being the largest of all our Warblers, as well as the most eccentric in behaviour. The back of this bird is olive-green, like that of so many of the family; the throat and breast are brilliant yellow, and over the eye and at the edge of the throat is a conspicuous white line. It is a common summer resident in many of our Eastern States. It is a very shy bird, and when approached, especially during the nesting-time, goes through with many strange performances in the air. Mr. Chapman says, "After an acquaintance of many years, I frankly confess that his true character is a mystery to me. . . . But that there is method in his madness no one who studies him closely can doubt."

The Oven-bird, or Golden-crowned Thrush, is one of the Ground Warblers, that in appearance resembles a small Thrush, having a white breast marked with brownish spots. It is olive-green above, without white 
markings on wings or tail, and has an orange-coloured crown bordered by black lines at the sides. This bird is common in our Eastern States, but is seldom seen on account of its retiring disposition. He has a liquid, melodious song, "the very force of which carries him up into the air among the tree-tops."

\section{VIREOS}

The Vireos constitute a family, embracing many species, of small, insectivorous birds that are peculiar to America. Their characteristic colour is olive-green, and on this account they are also called Greenlets. The Vireos inhabit both trees and undergrowth, and most of them have very melodious songs. Unlike many of the other insect-eating birds, they are rather slow in their motions, and obtain their food by gleaning the under surface of leaves and prying larvæ from crevices in the bark, rather than by darting after it in the manner of the Flycatchers. The Vireos are migratory, many species spending the summer in the United States and in the autumn returning to their home in the West Indies and South America.

A common species in eastern North America is the Red-eyed Vireo, or Greenlet, whose plumage is olivegreen above, with a slaty-grey crown, and a conspicuous white line over the eye. The under parts are pure white. A distinguishing character of this bird is its red iris. Like most of its relatives, the Red-eyed Vireo is a fine singer, and like them also, but in this character differing from most other birds, it sings while weaving its pensile nest of grasses, lichens, and. so on. 
A very handsome, but somewhat rarer form than the preceding in the United States, is the Blueheaded, or Solitary, Vireo, whose back is bright olivegreen, top and sides of head bluish-ash colour, wings marked with two white bars, and under parts pure white. This bird is the first of its family to reach the Northern States in the spring, and the last to leave for its southern home.

The White-eyed Vireo is abundant in summer in the undergrowth of our Eastern States. The bright olive-green of its upper parts are washed with greyish, and the wings have two distinct yellowish-white bars. A marked character is the white iris, which, however, is brown in the young bird. The White-eyed Vireo has considerable ability as a singer, and varies his own sweet song with the notes of other birds.

\section{$\dot{W}_{\text {agtails and Pipits }}$}

These birds are found principally in the Old World, only three out of the sixty or more known species inhabiting America. Though the Wagtails and Pipits are closely related, so far as colouration is concerned the two groups differ conspicuously: the Wagtails have a beautifully harmonious, but rather brightly coloured plumage, while the Pipits as a rule are clothed in sober brown, relieved by streaks and spots of darker brown. In both groups the legs are relatively long, and the inner quill-feathers of the wing, or inner secondaries, are so long that they reach the end of the primaries when the wing is closed-a character shared by the Larks. These birds do not hop, 
but walk or run along the ground, and have the habit of constantly wagging the tail. They feed upon in-, sects, which they catch both on the wing and from the ground. The hind toe-nail in both Wagtails and Pipits is greatly lengthened.

Two of the commonest European species are the Grey Wagtail and the White Wagtail, the former being remarkable for its long tail. Both are beautiful and delicately coloured little birds. The black throat of the male Grey Wagtail is worn only during the breeding season, being replaced by white in winter. This bird is a lover of mountain streams, preferring them to those that run through flat country. See Plate 11, Fig. 52.

The White Wagtail in its summer dress may readily be distinguished from its other common relative, the Pied Wagtail, by the greater amount of white on the sides of the neck, and by the beautiful pearl-grey of the upper parts, that of the Pied species being black. In winter they resemble each other rather closely; the black back being grey at this time, although darker than in the other species. See Plate 11, Fig. 53.

The Yellow Wagtail is an extremely common bird in many parts of the British Islands. It is a species which revels in wet meadows, and finds the company of cattle attractive for the sake of the flies which they stir up in the grass. The chin, throat, and under parts of this bird are bright yellow, and a yellow stripe runs over the eye.

In some respects the Pipits are like the Larks, but they are nevertheless probably not very closely related to the Lark family. In colouration they are very 
similar, and another external character which they have in common is the greatly lengthened hind toenail. The Pipits build their nests on the ground, usually in sheltered places, and the eggs of some species are much more brilliantly coloured than are those of the Wagtails.

The Tree-pipit is fairly well distributed throughout Europe, though on account of its sober colouring it seldom attracts attention. It has a pleasing and rather powerful, though limited, little song. While able to perch upon trees, the Tree-pipit, like the other species of this group, seems more at home on the ground, where it runs actively about, with much jerking of the tail. Resembling the Meadow-pipit, it is larger, and has a shorter hind-claw. See Plate 10, Fig. 49.

The smallest of the European Pipits, or Titlarks, is the Meadow-pipit. This dainty little bird may be seen in suitable localities throughout the year in the British Islands.

The American Pipit, or Titlark, is the most widely distributed species in this country. In colouring it is greyish-brown above, faintly streaked with darker brown; the under parts are buff, streaked on breast and sides with blackish. The end half of the outer tail-feather is white, the one next to it has white on the end, and the wing-coverts are tipped with white.

These little birds breed in the far North, migrating southward in winter to Mexico and Central America. When a flock is startled, it is said to rise high in the air, as if for a long flight, but after hovering for a few moments, to return to, or near, the place from which it rose. 


\section{LARKS}

There is a general notion among those who are not experts in the matter of the classification of birds, that the Larks are related to the Pipits and Wagtails, but whether this belief is well founded or not remains to be proved. As has been said, in certain characters they bear a superficial resemblance. The relationship between the Larks and the Finches, to be considered later, seems to be evident.

The Larks are chiefly natives of the Old World, though North America has representatives of the group in the Horned Larks. The family is distinguished from all the other Perching birds by the fact that the back of the leg is covered by small scutes, or scales. The long hind claw and the length of the inner quill-feathers of the wing in Larks has already been mentioned. Their bills are short and conical.

The best known of this family is the Skylark, so famous for its song, which is heard during nearly eight months of the year, and ranks next to that of the Nightingale in popular favour. It is one of the few birds that sing while on the wing, and the strong natural impulse to rise in the air when singing makes the efforts of a caged Skylark a most pitiful sight. Sometimes it will sing from the ground, but usually the Skylark ascends in a spiral course to a considerable height. The general colour of this bird is brown of varying shades, with slight touches of white or yellow. The breast is greyish-brown. See Plate 14, Fig. 74.

During migration these birds suffer appalling losses 
in their ranks, immense numbers being killed by dashing against lighthouses. As many as fifteen thousand are known to have been killed in this way in a single night.

Resembling the Skylark in general appearance, the Wood Lark may be distinguished by its smaller size, shorter tail, more pronounced crest, and the broad, pale stripe over the eye. The song of this bird is sweet and flute-like, and is uttered on the wing, the bird hovering in the air and descending spirally with half-closed wings. It does not mount like the Skylark, however, nor is its song so powerful and sparkling. The Woodlark receives its name from its ability to perch on trees, which the Skylark does not seem to have. See Plate 14, Fig. 75.

The Crested Lark is a fairly common species on the continent of Europe, but is rarely found in England. It is distinguished from the Skylark by the long drooping crest depending from the back of the neck, the absence of white in the tail, and by its somewhat larger form. See Plate 14, Fig. 76.

The Horned Lark, or Shore Lark, breeds in the Arctic regions of both Old and New Worlds. In winter it is found as far south in this country as North Carolina. The black feathers over the eye in this bird are lengthened to form little tufts, or "horns," from which it receives its name. The back is brown, streaked with darker colour, and the sides are pinkish brown, as well as the back of the neck and wing- and tail-coverts, while the throat and a line over the eye. are yellow. This species is found in the vicinity of the seashore, or in open country in the interior, but sel- 
dom in wooded districts. They are ground birds, and are usually seen in flocks.

A smaller but similar form to the preceding is the Prairie Horned Lark, a more southern species, and one that is extending its range eastward from the Mississippi Valley. Formerly confined to the prairies of the West, it now breeds in any suitable locality farther East. This bird has a white, instead of yellow, line over the eye. In singing, it is said to hurl itself aloft like the Skylark, and also to sing on the ground.

\section{Finches}

This is an enormous family of birds, the largest in the Order to which it belongs, and found in all parts of the world, except Australia and adjacent islands. While the plumage of many species is plain, that of many others is brilliantly coloured. Nearly all the Finches are song-birds, and many are favourite cagebirds. All are seed-eaters, although during the breeding season they capture great quantities of insects as food for their young. Most of the species are resident throughout their range, and not migratory to any extent, as are all the exclusively insect-eaters among birds. The Finches may be generally described as rather small birds having a short, pointed, conical beak, and nine primary quill-feathers.

One of the commonest of European Finches is the Greenfinch. It has no representative in America. The male is a beautiful bird whose colouring is in general green and gold, and the female resembles him, but is not so brilliantly coloured. This bird does well in confinement, and shows some capacity for learning the 
14.

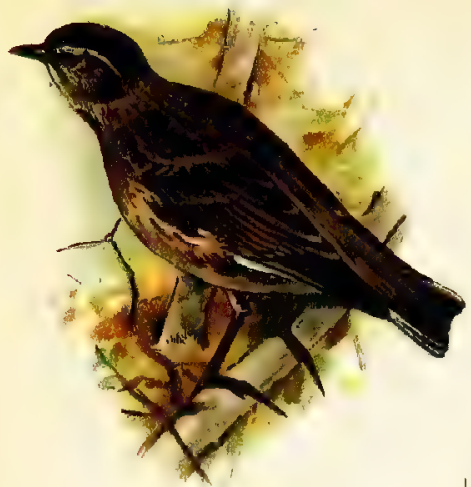

75. Wood Lark (Alauda arbarea).

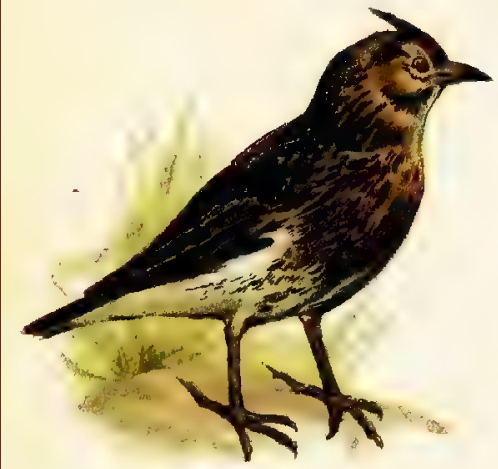

76. Crested Lark

(Galerita cristata).
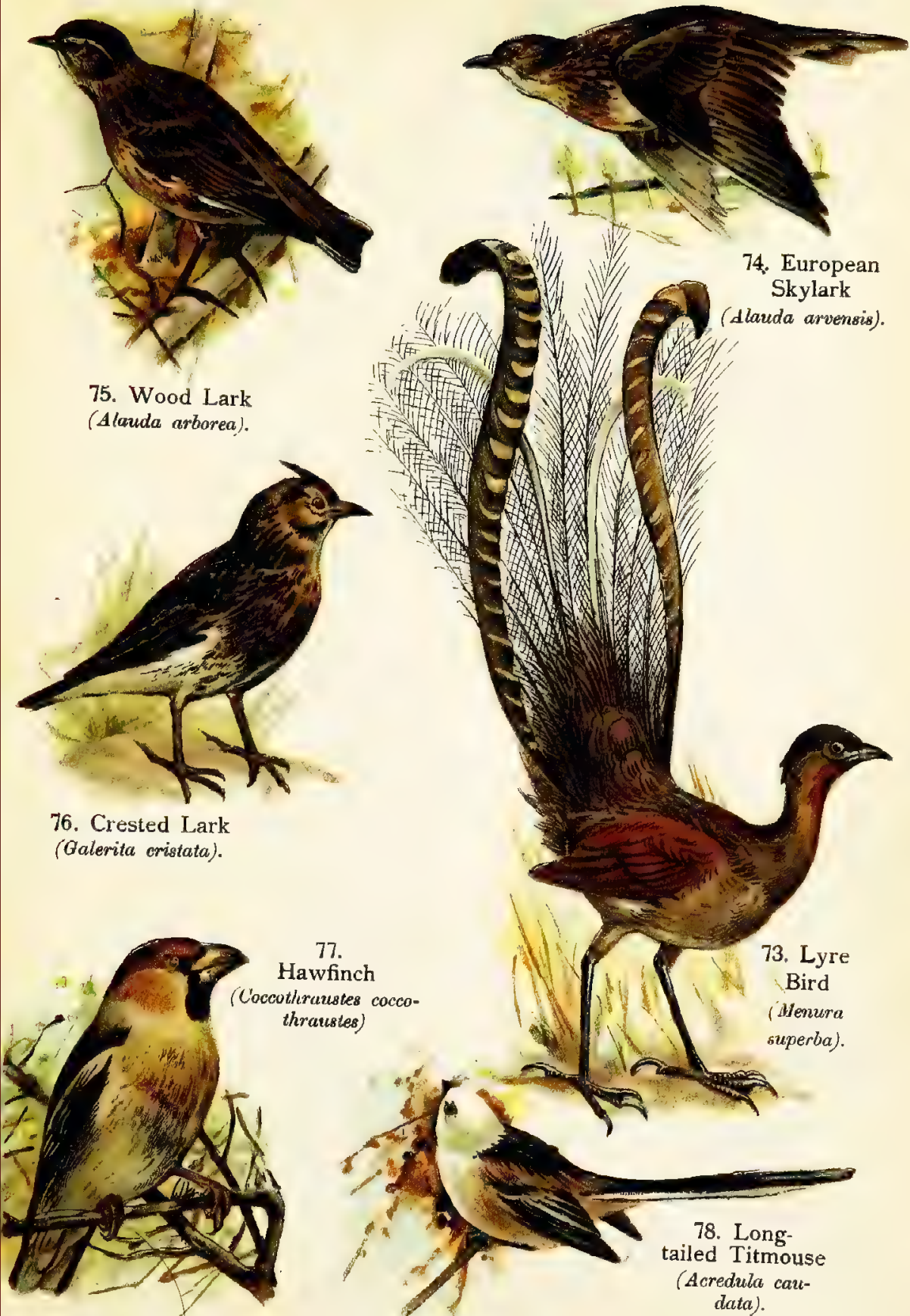

77.

Hawfinch

thraustes

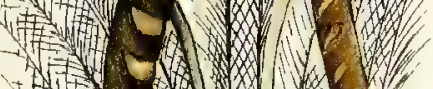

- 1701

ND

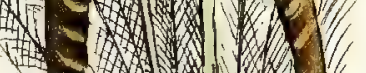

wit

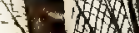

1) $00 \times 19$

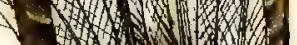

CHAf N W
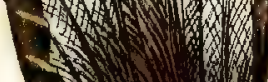

songs of other species, though it is by no means a skilled performer, and its own notes are rather monotonous. It is a lover of gardens and orchards. See Plate 16, Fig. 90.

The Hawfinch is found in nearly the whole of Europe and in parts of Asia, as well as in northern Africa. It is especially common in England, although it contrives remarkably well to escape observation. The plumage of the Hawfinch is much variegated and by no means conspicuous. It closely resembles that of the Chaffinch, but the Hawfinch is a larger bird-one of the largest of its family. A marked character is the great size of its beak, inside of which are curious crushing-pads, used in opening the hard-shelled stones of the hawthorn and other fruits of which it is very fond. See Plate 14, Fig. $7 \%$.

Perhaps the most beautiful of the Finches is the European Goldfinch, whose name is derived from the golden-yellow of its plumage. The sexes are coloured much alike, but the young are quite different-looking, being without the beautiful markings of the parents. The Goldfinch is a favourite cage-bird, and as it is not easy to keep in confinement, is constantly in demand by fanciers. In England thousands are caught yearly in nets, and so great have been the raids on their ranks that in many parts of the country where they were formerly abundant they have been practically exterminated. See Plate 17, Fig. 98.

Introduced into this country in 1878, the European Goldfinch is occasionally seen about New York City and in other parts of the Eastern States.

The American Goldfinch, more commonly called 
Yellow-bird, is a distinct species from the European. It is also a very beautiful little bird, having a bright yellow body, a black cap, and black wings and tail varied with white. The sexes are quite unlike in colour, the female being olive-brown above and yellowish below. In the fall the black cap of the male disappears and his colours in general fade until they approximate those of his mate. The sweet song and undulating flight of this little bird are well known. The American Goldfinch is quite common east of the Rocky Mountains.

The Siskin, or Aberdevine, is a near relative of the Goldfinch, which it resembles both in song and in manner of flight. It breeds in the Arctic regions of the Old World, and winters in many parts of Europe. The Siskin is especially abundant in the British Islands, where it is frequently kept in confinement on account of its melodious song. See Plate 18, Fig. 103.

The Pine Siskin, or Pine Finch, of this country, is also a native of the far North, but winters south to the Gulf States, and is found throughout almost the whole of North America. The colouring, in general, is olive-brown above, whitish, streaked with black, below, with yellow on wings and at base of tail. The latter is slightly forked. Siskins feed chiefly on the seeds of pines and hemlocks and other coniferous trees.

The home of the little bird known as the Serin is in the southern parts of Europe and northern Africa, although it is an occasional visitor to Great Britain. This Finch has a peculiar interest, inasmuch as it is probably the ancestor of that most popular 
of cage-birds, the Canary. It is a slightly smaller bird, with shorter wings and longer tail, and its song is not so melodious nor so varied as that of the Canary. See Plate 18, Fig. 102.

The Canary is closely allied to, if, indeed, it is not a sub-species of, the Serin. The wild Canary is olivegreen above, streaked with darker colour, and greenish-yellow below; but by ages of careful breeding, many varieties have been produced, the most common being pale yellow over the whole body. This is said to be deepened to a brilliant flame-colour by mixing cayenne pepper in the food. The name of the bird is derived from the fact that it is a native of the Canary Islands, where it is very abundant. It is a popular cage-bird all over the world. The song of the wild Canary, though pleasing, is said to be surpassed by that of the domesticated varieties. See Plate 18, Fig. 105.

Of the House-sparrow, or English Sparrow, as it is usually called in this country, though it is not known to be a native of England, little need be said, for it is, unfortunately, now common everywhere. Although, like the rest of its family, chiefly a seedand grain-eater, it was introduced into the United States in the expectation that it would destroy noxious insects that were injuring trees in our public parks. It has, however, done far more harm than good, proving a great pest to farmers, and driving away many of our native birds from their former haunts. The House-sparrow is extremely hardy and prolific, and adapts itself with wonderful facility to new environment. It has no song, and its one note is 
by no means pleasant to the ear. See Plate 16, Fig. 93.

. The European Tree-sparrow, which is closely related to the preceding species, is a relatively rare bird in comparison. It also was introduced into this country, where it has become naturalised. While much like the House-sparrow, it may be distinguished by its chestnut, instead of grey, crown, and the two white bars across the closed wing. Further, while in the former species the sexes are quite dissimilar, in the Tree-sparrow they can hardly be distinguished. See Plate 16, Fig. 94.

The American Tree-sparrow is found in the eastern part of the country, breeding north of the United States, but wintering throughout them, as far west as the Great Plains. A small black spot in the centre of the greyish-white breast is an aid in identifying it. It has a sweet liquid warble, somewhat Canary-like in character.

The Field-sparrow of this country gets its name from its habit of frequenting fields and open country, rather than more wooded sections. It closely resembles the Tree-sparrow in colouring, but is somewhat duller. This bird is common in summer throughout our Eastern States. It nests on or near the ground.

Two other very well known species in eastern North America are the Song-sparrow and the Chippingsparrow. Both are sociable little birds, often coming about houses in search of food. The former is one of our sweetest and most constant songsters, being heard at all hours during the day. This bird is reddishbrown above, streaked with black and ash, and white 

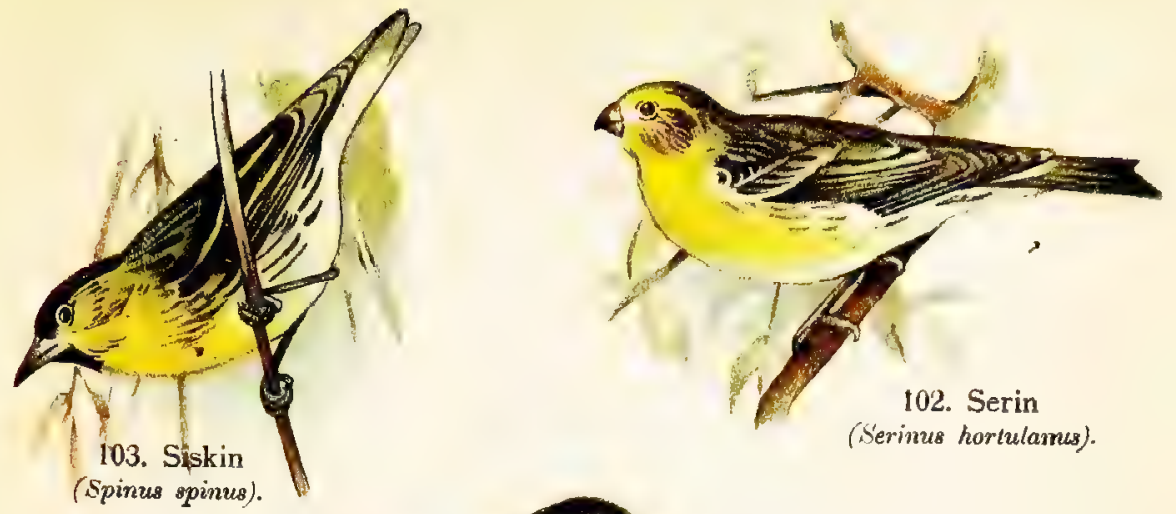

(Serimus hortulames).

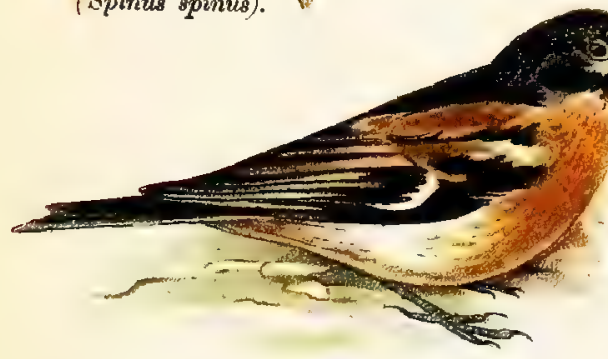

104. Brambïing (Fringilla montifringilla).

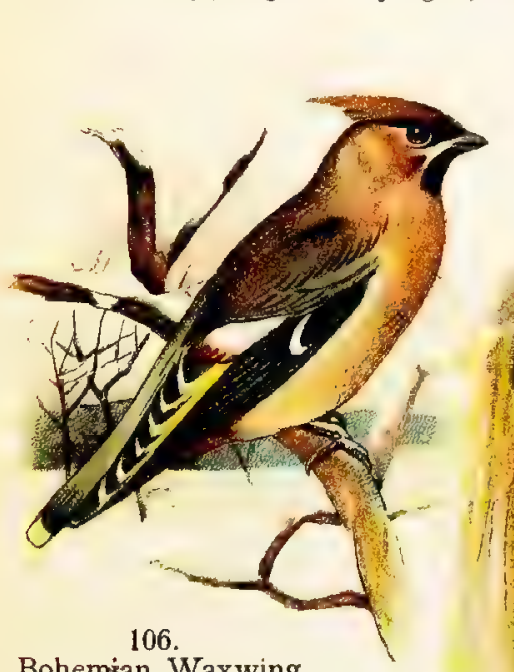

Bohemian Waxwing

(Ampelis garrulus).

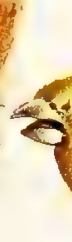

107.

European

Swift

105.

Canary

SSerinus

(canarius).
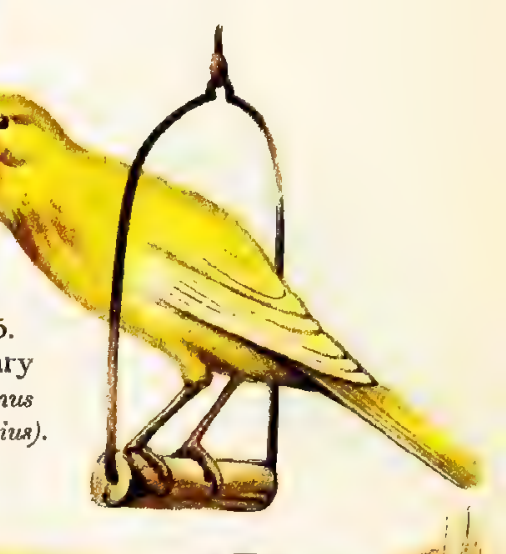

(Cyprelus ария).

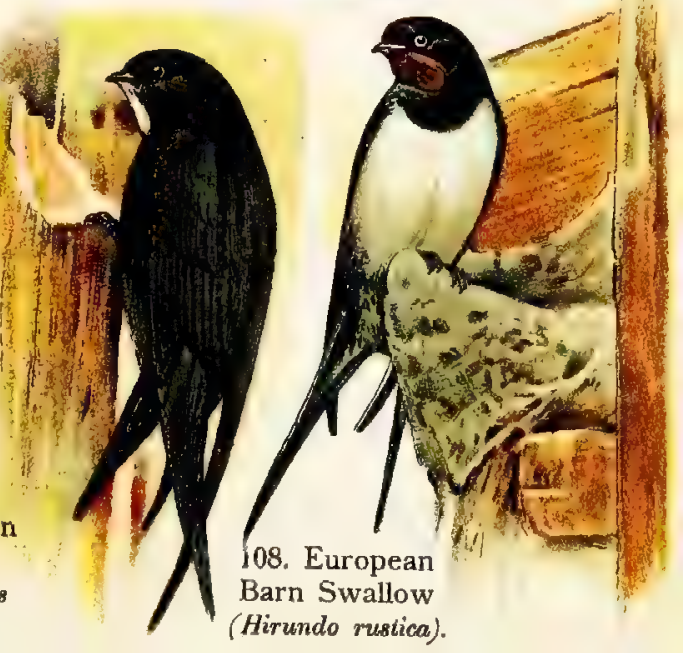



below, the breast and sides having streaks of dark reddish, and the crown striped with black. Both species build in trees or low bushes, often very near houses.

The Common Chaffinch is even more abundant in many parts of Europe than the House-sparrow, and is especially plentiful in the north of England. The male bird has a tuneful song, and is much esteemed as a cage-bird. It was a common custom, formerly, to sear the eyes of these birds with a hot iron in order to make them sing better, and even now, in order to perfect their song, they are sometimes made to pass much of their time in the dark. See Plate 17, Fig. 97.

The Chaffinch is a friendly little bird, building its nest in gardens and orchards near human dwellings.

The Brambling, or Mountain Finch, is a near relative of the Chaffinch, and is even more brilliantly coloured, its plumage being a combination of black, orange and white. This bird breeds in the northern parts of Europe and Asia, migrating south in winter. In some years it is remarkably abundant in Great Britain, especially when severe weather prevails on the continent of Europe. The wonderful black head and neck are assumed just before the breeding season - not by a change of feathers, but by the wearing away of the brown tips of the fall and winter plumage. See Plate 18, Fig. 104.

Another common song-bird, found throughout Europe, western Asia, and the north of Africa, is the Linnet, also in great demand as a cage-bird. The wonderful rose-red breast which distinguishes the male is never regained by captive birds after their first moult, but is replaced by yellow. The name, Linnet, 
is derived from the Latin word for flax, linum, on account of the bird's fondness for the seeds of that plant. See Plate 17, Fig. 100.

A very beautiful little bird of the Finch family found in southwestern Europe and the British Islands, is the Bullfinch, which gets its name from the thickness of its neck. The sexes differ conspicuously in colour, the females lacking completely the beautiful red on the breast of the male. In her it is replaced by chocolate-brown. The young resemble the female, but lack the black cap, which is common to both sexes in the adult birds.

The Bullfinch, like the Chaffinch, builds a remarkable nest, though the workmanship of the two differs strikingly. The first makes a wonderful nursery of fine moss, wool, and lichen felted together, while the Chaffinch erects a platform of small twigs, surmounted by fine roots and a little hair fashioned into a shallow cup, in which the eggs are laid. See Plate 16, Fig. 91.

A variety of the Bullfinch was discovered in Alaska, in $188 \%$.

The home of the Pine-Grosbeak is in the far North of both hemispheres-in the region near the Arctic circle, wherever cone-bearing trees abound. Here it flourishes, feeding on buds, seeds and berries, varied by such insects as come within its reach. In this country it migrates south in winter as far as Virginia. In the male the plumage is mostly rose-red, changing to ashy below, the wings darker, with white bars. In the female the head and rump are brownish-yellow. The American species is similar to the European, but is 


\section{PURPLE FINCH-INDIGO BUNTING 219}

somewhat more brightly coloured. See Plate 16, Fig. 92.

The Pine-Grosbeak has a variety of pleasing notes, and is a popular cage-bird in many countries.

Closely allied to the preceding species is the Crossbill. This bird derives its name from the fact that its mandibles cross each other at their tips, a peculiarity which looks like a deformity, but which enables the bird to wrench apart pine-cones and extract from them the seeds which form the bulk of their food.

The Common Red Crossbill is found in both this country and Europe, breeding in the northern parts of the continents and wintering southward. It migrates in large flocks. Oúr American species is slightly smaller than the European, and is more brightly coloured. Before the beautiful red plumage, which distinguishes the male, is assumed, a livery of orange-yellow is worn. The general colour of the female is greenish-yellow, with brown wings and tail. See Plate 15, Fig. 79.

The Purple Finch is a common bird of eastern North America whose name is quite misleading, for the colour over its entire body is dull rose-red, darkening on wings and tail. The latter is slightly forked. The female differs markedly in appearance, being greyish-brown above, streaked with black, and white below, streaked or spotted with dark colour. The male does not assume adult plumage for two years, until that time resembling the female in colouring. Both sexes have small tufts of bristly feathers over the nostrils. The Purple Finch is one of our most 
melodious song-birds. His sweet and liquid notes are said to resemble those of the English Chaffinch.

The Redpoll, or Redpoll Linnet, is an inhabitant of the Arctic regions of both the Old and the New World, migrating south in this country to about the middle of the United States. The bright red crown of both sexes gives it its name. In the male the throat, breast, ar I rump are also red, the upper parts blackish-brown, streaked. The female resembles him, but lacks the rose colour on the body. In general habits it is like its relative, the American Goldfinch, and is very friendly in disposition, frequenting orchards and gardens and often closely approaching houses. Its song is said to be musical, but is seldom heard far from its breeding-grounds in the North.

The Indigo Bunting, an exquisitely coloured little bird often seen in the Eastern States, is bright blue on the back, a deeper blue on the head, and has black wing- and tail-feathers margined with blue. The female is quite Sparrow-like in appearance, plain brownish-grey taking the place of the rich blue in the plumage of the male. The outer wing- and tailfeathers, however, are slightly washed with blue. The cheery song of the Indigo Bunting is especially welcome during the month of August, when most of our other song-birds are silent.

In the Towhee, or Chewink, the upper parts, throat and breast are black, the sides reddish, and wings and tail marked with white. This is another member of the great Finch family that is found in eastern North America, where it is found inhabiting dense thickets and undergrowth. In this bird the iris is red, but in 
16.
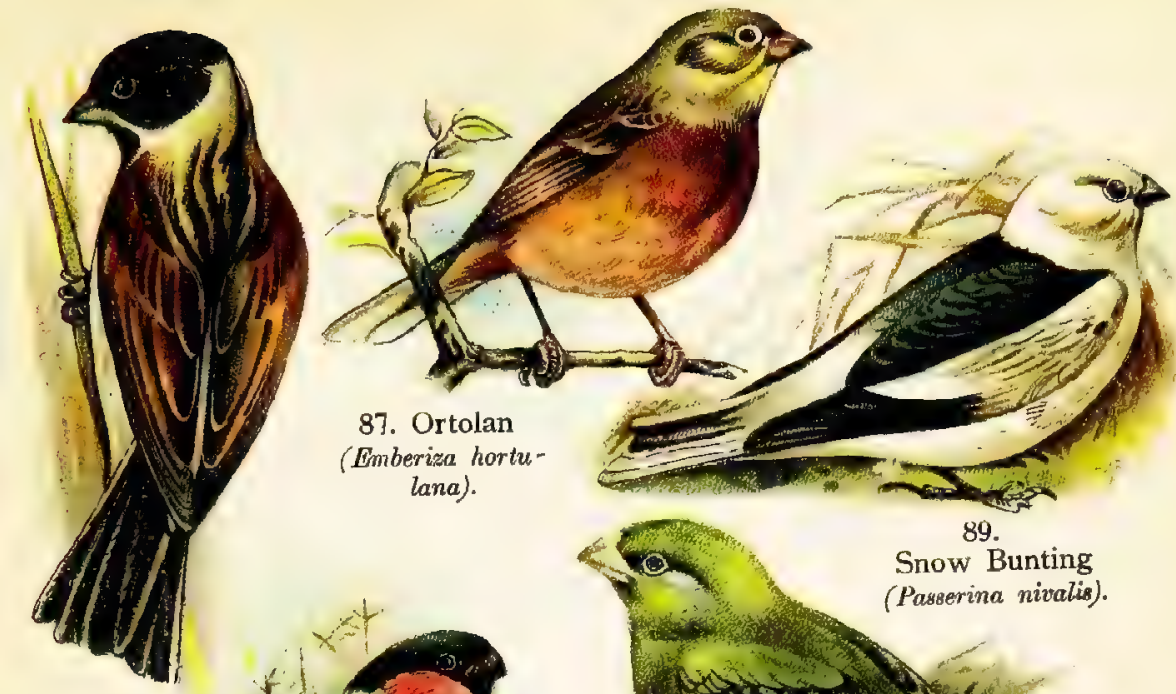

87. Ortolan

(Emberiza hortulana).

88. Reed

Bunting

(Eniberiza schoniclus).
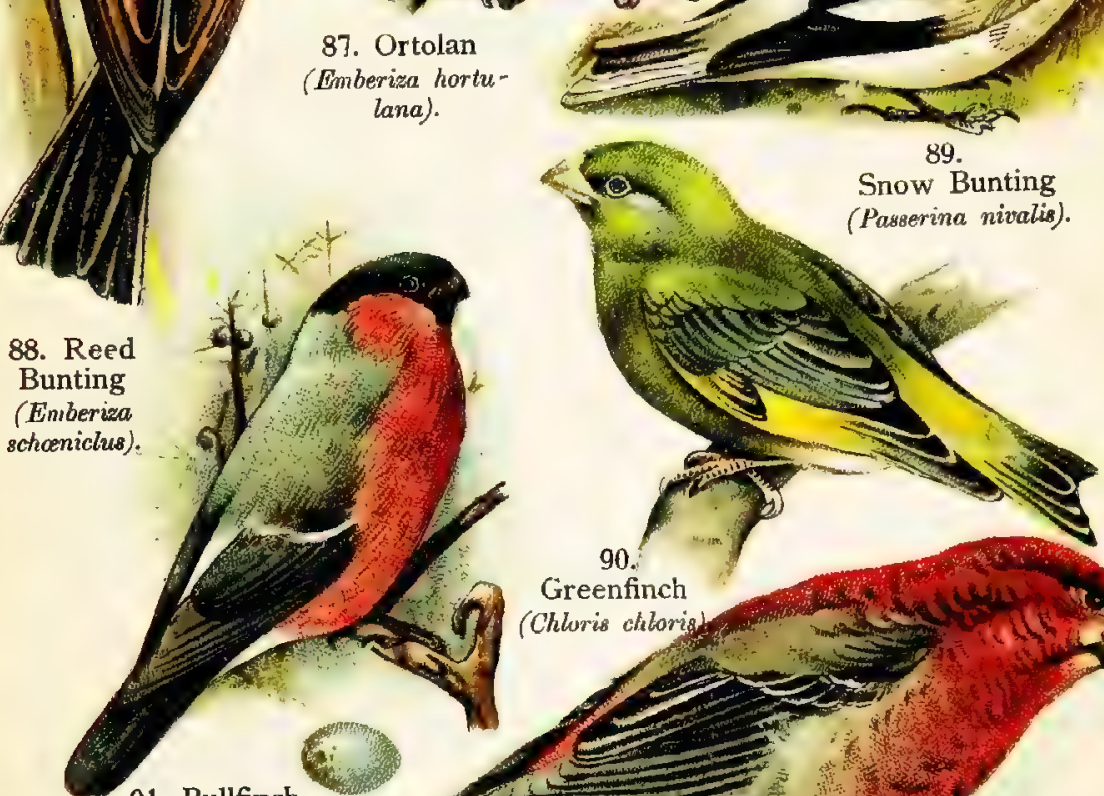

Greenfinch (Chluris chlorish

91. Bullfinch (Pyrrhula pyrrhula).
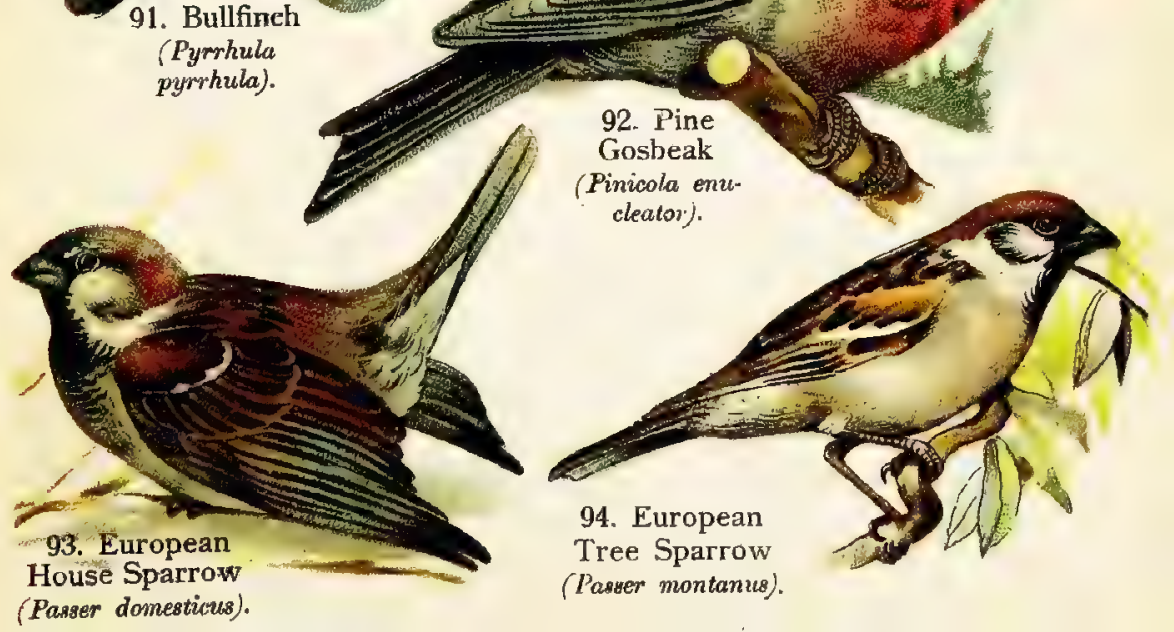

the White-eyed Towhee, a more southern species, it is yellowish-white.

The Snowbird, or Junco, breeds in the northerm parts of both continents, and flocks of them are seen migrating southward as the cold weather comes on. The male is slate-grey above, darkening on the head, and white below, and the female resembles him, but is somewhat browner above.

Often seen in company with the preceding species, the Snowflake, or Snow Bunting, is sometimes confused with it. This bird, however, is pure white above, with black markings on wings and tail, and the bill is black, while in the Snowbird it is white. After the breeding season, the white of the upper parts becomes washed with brown. These little birds are not at all shy, and are frequently seen in winter seeking food in the neighbourhood of human dwellings. See Plate 16, Fig. 89.

The Paradise Whydah-bird is a South African species, found on swampy ground where reeds and long grasses flourish. Kaffir children capture numbers of the males with limed twigs and strings, and also by running them down, the birds being hampered with their long tails. During the season of courtship these birds perform wonderful evolutions in the air. On account of its beautiful plumage, as well as for its song, the Whydah-bird is frequently kept in confinement in European countries. See Plate 17, Fig. 95.

Both the Amaduvade and Paradise Whydah-bird belong to a group of birds found in Africa and parts of Australia called Weaver-birds, from the remarkable nests which they weave of roots and grasses. By 
some authorities they are considered a distinct family, though they admit that it is hardly to be distinguished from the Finch family. All are small, Sparrow-like birds, and feed principally on seeds and insects.

The Amaduvade, or Strawberry-finch, is very popular as a cage-bird, and is imported into European markets in enormous numbers. The male in breeding plumage is very beautiful, and, in addition, has a brief but sweet song, which is said to resemble a bugle-call. The female is less brilliant, being brown above, with a light patch of red on the rump, and buff-coloured below. These birds moult twice dur:-ig the year, and after the breeding season the male assumes the dress of the female. The males are pugnacious little birds, and fight with spirit, on which account they are kept by the natives in India to afford them sport. See Plate 17, Fig. 96.

The Java Sparrow, as its name implies, is a native of the Island of Java, where, like the House-sparrow here, it is a pest. In the countries where it has been introduced it commits great ravages on fields of grain and rice. Of late years the Java Sparrow has become much sought after as a cage-bird, and breeds readily in confinement. From the domesticated birds a white race has been raised, which is highly prized. See Plate 17, Fig. 99.

Though popularly called a "Sparrow," this bird is not really very closely related to the true Sparrows, such as the House- and Tree-sparrows.

The Buntings are generally regarded as forming a sub-family of the Finches. Many of them are brightly coloured, but others, such as the Corn Bunt- 
ing, or Common Bunting of the Old World, is quite sombrely clad. This bird bears a striking resemblance to the Skylark, from which, however, it may easily be distinguished by the absence of the conspicuously long claw to the hind-toe. See Plate 15, Fig. 86.

The Yellow Ammer, or Yellow Bunting, recëives its name from the bright yellow of the head, neck and lower parts. Like the preceding species, it is a common European resident, but has no representative in this country. The name here is frequently erroneously applied to the Flicker, or Golden-winged Woodpecker, which has no affiliation with the Buntings. The bird which most nearly resembles the true Yellowhammer (a form in which the name often appears) is the Bobolink in its fall plumage. The Yellowhammer is also known as the Writing-lark, because of the curious scribblings, as of a pen, over its eggs; though this character is shared by the eggs of the Buntings in general. See Plate 15, Fig. 85.

Perhaps the most celebrated of all the European Buntings is the Ortolan, because of the fame which it has unfortunately acquired as a table delicacy. Common throughout the greater part of Europe, this bird, as soon as the breeding season is over, returns southwards in vast flocks. On both of its migratory journeys, to and from Europe, it is beset by bird-catchers, who make enormous hauls. The victims are kept alive in dark places, and fed until they become very fat, when they are killed to supply the table. The natural food of this bird consists of insects and seeds in about equal quantities. The Ortolan much resembles its relative, the Yellow Bunting, but the head is greyish 
instead of yellow. Neither species has much musical ability, though their notes are heard almost continuously during the summer months in European countries. See Plate 16, Fig, 87.

Wherever sluggish streams and reedy marshes abound throughout Europe, there the Reed-bunting may be looked for. In the spring, it is rather handsome in its reddish plumage and black head, relieved by the white of the under parts, but in the autumn, after the new plumage has been assumed, the black hood is obscured by brown tips to the feathers. As winter proceeds, these tips gradually wear off until the black crown is once more in evidence. See Plate 16, Fig. 88.

Though in general appearance resembling the Reed-bunting, the Lapland Bunting may be distinguished by the long claw of the hind-toe, which has gained for it the name of Long-spur. See Plate 15, Fig. 81.

The home of this bird is in the far North; it is, indeed, a circumpolar species, frequenting swampy lands beyond the limit of forest growth. Until the year 1892 the Lapland Bunting was extremely rare in the British Islands, but since that time England especially has been invaded by great numbers, annually, though only a few have ever been seen in Scotland.

The beautiful Cardinal-bird, or Virginia Nightingale as it is sometimes called on account of its famous song, is a common species in the eastern parts of the United States. It is from eight to nine inches in length, the face is black, the bill red, and the head 
bears a long crest of feathers. Most of the plumage over the entire body is a deep rich red; darker in crest, wings and tail, and the back is tinged with greyish. The female is duller in colour than the male. Both sexes have a charming song, that of the female being even more pleasing in quality than her mate's. Inhabiting thickets and undergrowth, this bird contrives, in spite of its brilliant colouration, to escape observation, even when its rich rolling notes proclaim its near presence. See Plate 17, Fig. 101.

\section{TANAGERS}

The Tanagers form a group of New World birds, numbering about three hundred and fifty species, and very closely allied to the Finches. Indeed, the characters which distinguish the two families are very slight and technical. The Tanagers are birds of beautiful and varied plumage, many of them being brilliantly coloured, and the females differ conspicuously in colouration from the males. They are most abundantly represented in tropical America, only five species summering in the United States. The Tanagers are woodland birds, feed chiefly upon insects and fruit, and only a few species have any vocal ability, most of them having very weak voices.

A very beautiful species common in the eastern part of this country is the Scarlet Tanager, also known as the Blackwinged Redbird. The male bird is a brilliant scarlet, with black wings and tail, while the female is a light olive-green above, darkening on wings and tail, and greenish-yellow below. Towards the end of the summer the male begins to moult his 
scarlet plumage, and replace it with the greenish colours of his mate; but the black wings and tail are retained. The song of the Scarlet Tanager is characterised as "a loud, cheery, rhythmical carol, suggesting the song of the Robin."

Another exquisitely coloured species is the Summer Redbird, or Summer Tanager, also common in the eastern part of this country as far north as Canada. This bird is a rich rose-red over the entire body, and the female is greenish and yellow, closely resembling the female of the preceding species.

The Little Calliste, or Paradise Tanager, is shown as a good example of the vividness which some of these birds display in their plumage. It is one of the Central and South American species, and is fairly common as a cage-bird. See Plate 19, Fig. 113.

\section{Crows}

Although in the past there has been much difference of opinion among ornithologists as to which family of birds is entitled to the highest place in their class, it is now generally conceded that the Crows are the most perfectly developed of all the Passerine birds. In both sexes, and in all stages of development, the plumage is practically the same; each primary and wing-covert is perfect in structure; and the scales on legs and feet are more strongly marked than in any of the other birds. And although most of the family have no powers of song, their voices being extremely harsh and disagreeable, the voice-muscles of all are remarkably well developed. The Anstralian Piping Crow, a beautiful bird having plumage varied with 

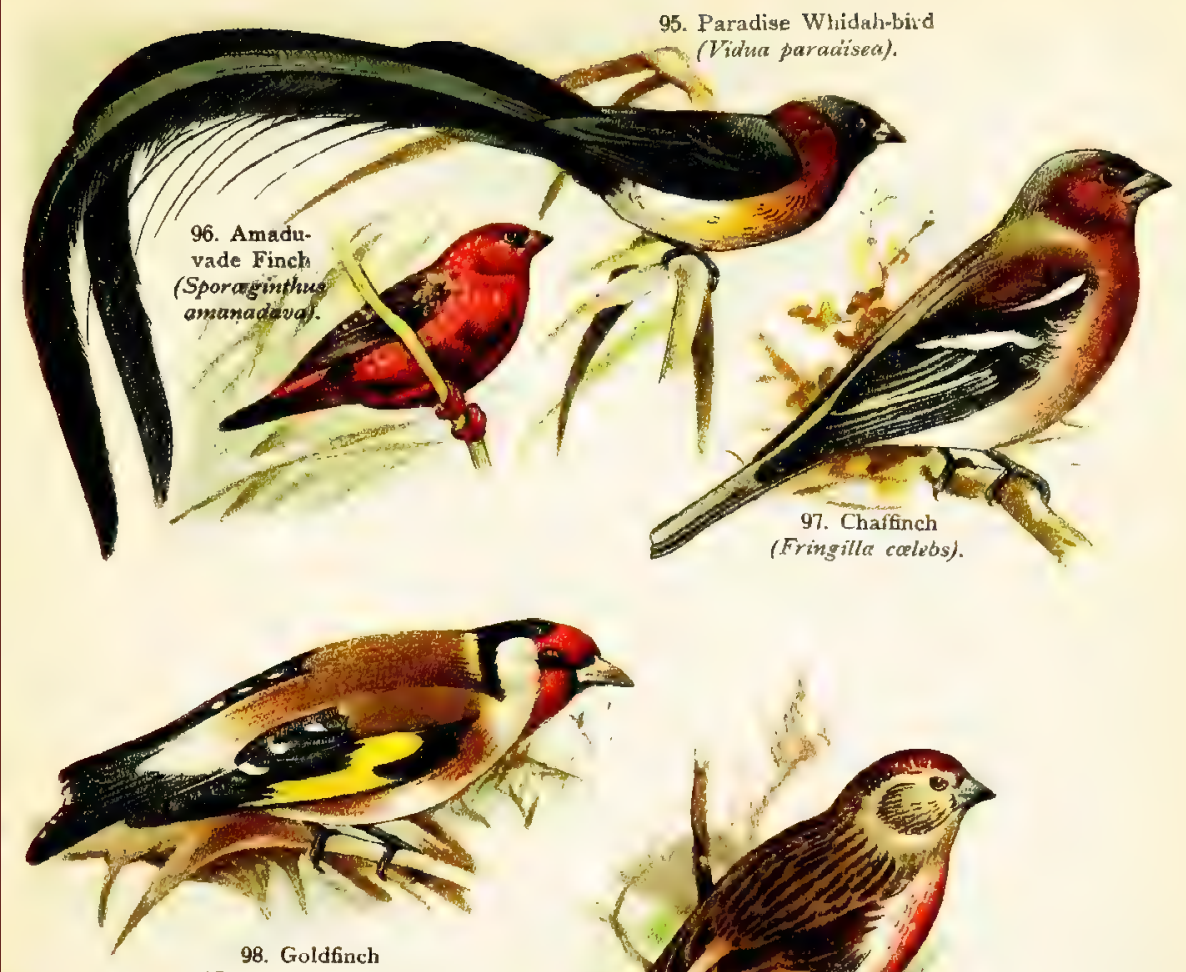

(Fringilla coelebs).
(F)

(Carduelis carduelis).
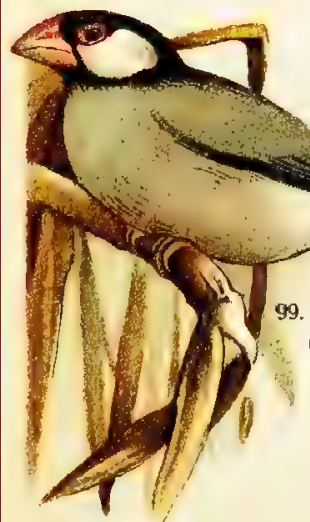

99. Java Sparrow

Padda ory-

aivora).

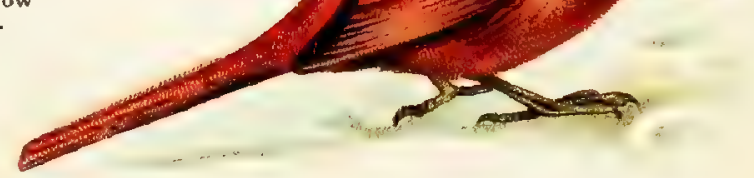

101. Cardinal (Cardinalis eardinalis). 

black and white, is, however, exceptional among its relatives in possessing a most enchanting flute-like song, to which it gives utterance at frequent intervals.

The eyes of Crows are bright and intelligent in expression. The wariness and sagacity of these birds, indeed, is well known, and these traits have doubtless been further developed on account of the constant persecution to which they have for ages been subjected by agriculturists, who are their sworn enemies in consequence of the injury Crows inflict upon crops. They will return again and again to some favourite feeding-ground, their wonderful sagacity enabling them to avoid poison, traps and other snares set for their destruction. The food of Crows is much varied. They are especially fond of small living creatures, such as mice, nestlings, worms, and so on, but they also eat carrion, and, indeed, they are practically omnivorous, eating fruit, grain and seeds as well. The great Ravens of Europe and America will even attack and kill small lambs.

The Crow family numbers about two hundred species, found in all parts of the world, except New Zealand. In colour most of them are shining black, somewhat iridescent on back, wings and tail, although the plumage of certain species, as the Jays, is brilliantly coloured. The bills are stout, rather long and powerful, and the base of the upper mandible is covered with bristle-like feathers. The feet are strong, and the toes end in rather heavy, curved claws.

Crows have a peculiarly jaunty manner of walling, and in disposition are a strange mixture of shyness and boldness. They may be thoroughly tamed, and 
make most interesting and affectionate pets, exhibiting remarkable intelligence. A curious characteristic habit is the stealing and secreting of small bright objects that attract their attention, about which they are usually so cunning that it is difficult to detect them in their thefts.

The best known species in this country is the common American Crow, found abundantly throughout North America, and too familiar to require more than brief mention. The plumage is black over the whole body, with purplish reflections, and the female is somewhat duller than the male. The nest is built of sticks, plastered with clay, and lined with feathers and other soft materials. Both male and female take turns in brooding the eggs, and are untiring in their devotion to their young. In the fall, Crows gather in enormous flocks, chattering and "cawing," and making a terrific din.

The European species that most nearly corresponds to the preceding is the Carrion Crow, a slightly larger form, common in western Europe, and so called from its fondness for carrion. Unlike the American Crow, this bird is seldom seen in flocks, being much more solitary in habit. Its voice also is quite different.

The Fish Crow, closely resembling the Common Crow, but smaller, is found in large numbers in our Southern States. As the name implies, this bird feeds largely on fish, and is usually found along the coast or not far inland. It is especially common in Florida, and at places along the Indian River every post and tree is occupied by individuals, who keep up 
a continual calling. The voice differs from that of the Common Crow, being hoarser and more nasal, and easily distinguishes the two species.

The largest and most famous of all the Crows is the Raven, found in the northern parts of both hemispheres. In colouring it closely resembles the Common Crow, the plumage over the entire body being black with steel-blue reflections; but the feathers on the throat are long and pointed, while in the Crow they are short and rounded. The bill of the Raven is enormously large and powerful, and the bird will attack and kill small lambs, and even sheep that have been partially disabled. It also eats rabbits, birds, eggs, and carrion, and, like the other members of its family, feeds on grain and fruit as well, being extremely voracious. See Plate 20, Fig. 116.

The Raven is easily tamed, and as a pet has few rivals, becoming much attached to its master and following him about like a dog. It can also be taught to "talk," or to imitate sounds of the human voice, in this respect surpassing some of the Parrots.

The American Raven is smaller than the European species, but is otherwise identical. It is found in parts of the West, especially where the Crow is not commonly seen.

The Rook. is peculiar among Crows in having a bare face. Young Rooks have the face feathered, as in the other Crows, and the nostrils protected by stiff, forward-pointing bristles; but after the first moult, these, together with the rest of the feathers of the face, are shed, and thereafter the skin remains bare and 
white, having the appearance of being covered with powder. Why these feathers should thus be shed and never regained, is a mystery which many naturalists have attempted to solve. See Plate 20, Fig. 117.

The Rook is as abundant in Europe as the Common Crow here, living in societies called rookeries, composed of many thousands of birds and nests. Like our species, too, it is a great pest to farmers, but its extreme cunning enables it to avoid many traps set for its destruction. Rooks are not considered as intelligent, however, as the Crow and the Raven, though they are sometimes tamed for pets. The young birds are fairly good eating, and many of them are shot for the table.

The Jays are found in both the Old World and the New, usually in wooded districts. All have harsh, discordant voices, but wonderful ability to mimic other birds. Many of them are very beautifully coloured. They have long tails, and short rounded wings. A character that distinguishes the Jays is their peculiarly light, bounding hop.

The European Jay is a prettily coloured bird inhabiting many parts of Europe, and is especially abundant in Great Britain, in spite of ruthless persecution at the hands of game-keepers, who grossly exaggerate the harm it does. It feeds largely on acorns and other forest seeds. See Plate 20, Fig. 119.

The American Blue Jay is very striking in colour, being beautifully marked in various shades of blue, with a mixture of black and white. Like its European relative, it has a feathered crest, which it constantly 

raises and depresses. The Blue Jay is extremely noisy, keeping up a continual chattering and calling in its harsh and penetrating voice, and mimicking other birds apparently for its own amusement. It appears to take especial delight in frightening smaller birds by imitating the cry of the Sparrow-Hawk.

The Canada Jay is a slightly smaller form than its blue relative, and is ashy grey in colour, with black and white markings. It is found in the northern part of this continent, coming southward in winter as far as New England.

The Jackdaw and the Magpie are two common European birds of the Crow family, which share the characteristics of the tribe in general. Magpies have very long tails, and in form are more graceful than the tree Crows. Both species are easily tamed and taught to imitate the human voice to some extent. They are very cunning, and are particularly addicted to stealing small bright objects and carrying them to their nests, or hiding them in other places. See Plate 19, Fig. 114.

The American Magpie, found in the western part of North America, is slightly smaller than the European, but is like it in colouring. The Jackdaw has no representative in this country. See Plate 20, Fig. 115.

The Nutcracker is an Old World bird whose nearest relative in this country is Clark's Crow, found on the western slopes of the Rocky Mountains. The plumage of the Nutcracker is brown, spotted with white. The seeds of cone-bearing trees form its prin- 
cipal food, but it also eats insects. The seeds are held in the claw and cracked with the bill, but the bird is not known to crack nuts in this manner, as its name would lead one to suppose. See Plate 20, Fig. 118. 


\section{INDEX}

Acanthus linaria (Redpoll) ...................... 220 Accentor modularis (Hedge Sparrow). (Plate 12, Fig. 58) 203 Accipiter atricapillus (American Goshawk)............ 6r

" cooperii (Cooper's Hawk) .............. 62

" velox (Red-tailed Hawk).................. 62

“ nisus (European Sparrow Hawk).... (Plate 3, ACCIPITRES Fig. I2) ...................... 6I

Acredula caudata (Long-tailed Tit)...(Plate I4, Fig. 78) 183 Acrocephalus palustris (Marsh Warbler)..... (Plate 13, Fig. 64) ..................... 202

Acryllum vulturinum (Vulturine Guinea Fowl)....... 82 Actodromas minuta (Little Stint)....(Plate 32, Fig. 183) 109 minutilla (Least Stint)............... I09 Ægialitis alexandrina (Kentish Plover) (Plate 30, Fig. I74) I03 hiaticula (Ring Plover).... (Plate 30, Fig. I73) I02 meloda (Piping Plover)................ I03 Aid galericulata (Mandarin Duck) ............... 49 Aix sponsa (Woo'd Duck) .................... 49 Ajaia ajaja (Roseate Spoonbill)................. 39 Alauda arborea (Wood Lark).........(Plate I4, Fig. 75) 2I I " arvensis (Skylark)..........(Plate I4, Fig. 74) 210 " cristata (Crested Lark)...... (Plate 14, Fig. 76) 2 II Albatross, Black-browed (Diomeda melanophrys) (Plate 38,

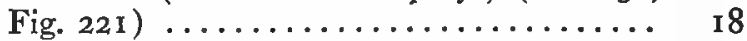

" Sooty (Phœbetria fuliginosa) ............. I9

"Wandering (Diomeda exulans) ........... I9 Alca torda (Razor-billed Auk)...... (Plate 40, Fig. 239) I2I Alcedo ispida (European Kingfisher)... (Plate 9, Fig. 40) I44 Alle alle (Dovekie).............. (Plate 40, Fig. 236) I23 Amaduvade (Sporæginthus amandava). (Plate I 7, Fig. 96) 222 Amazona æstiva (Blue-fronted Amazon Parrot) (Plate 8, 
Ampelis cedorum (Cedar Waxwing)............. I90 garrulus (Bohemian Waxwing) (Plate I8, Fig.

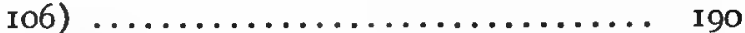

Anas boschus (Mallard) ............ (Plate 35, Fig. 203) 47

" obscura (Black Duck).................. 48

Anhinga anhinga (Snake Bird) ......(Plate 38, Fig. 222) 25

Ani (Crotophaga ani) .................... I39

"Groove-billed (Crotophaga sulcirostris).......... I40

Anous stolidus (Noddy Tern) . . . . . . . . . . . . . I I9

Anser anser (Grey-lag Goose)......(Plate 34, Fig. 198) 52

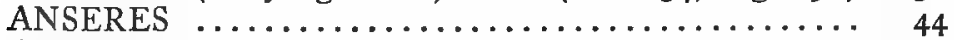

Anthropoides virgo (Demoiselle Crane) ........... 94

Anthus pensilvanicus (American Pipit)........... 209

" trivialis (European Tree Pipit) (Plate Io, Fig. 49) 209

" pratensis (Meadow Pipit)............... 209

'Antrostomus carolinensis (Chuck-will's-widow)....... I50

" vociferus (Whippoorwill) ............ I 49

Aptenodytes longirostris (Emperor Penguin)......... 2 I

patagonica (King Penguin)... (Plate 40, Fig. 234) ...................... 2I

“ parvus (

Apteryx (Apteryx mantelli).........(Plate 28, Fig. I6o) 7

Aquila chrysaëtus (Golden Eagle).......(Plate 2, Fig. 8) 63

maculata (Spotted Eagle)..... (Plate 3, Fig. Io) 63

Ara ararauna (Blue and Yellow Macaw).(Plate 8, Fig. 34) I35

" hyacinthia (Hyacinthine Macaw)........... 136

" macao (Red and Blue Macaw) (Plate 8, Fig. 35) I36

Ardea cineria (European Heron) (Plate 33, Fig. I92) 33

" herodias (Great Blue Heron) ............. 33

" occidentalis (Great White Heron).......... 34

" wardi (Ward's Heron) .............. 33

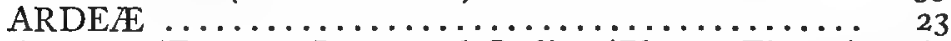

Asio otus (European Long-eared Owl).. (Plate 5, Fig. 20) I6I

Astragalinus tristis (American Goldfinch)........... 213

Astur palumbarius (European Goshawk). (Plate 4, Fig. 14) 6r

Audubon .............................. 126

Auk, Great (Plautus impennis) ............... 123

" Little (Alle alle)...........(Plate 40, Fig. 236) 123

" Razor-billed (Alca torda)..... (Plate 40, Fig. 239) I2I

Auks

I 2 I

Avocet, American (Recurvirostra americana) ......... 104

Avocet, European (Recurvirostra avocetta). (Plate 32, Fig.

I84) $\ldots \ldots \ldots \ldots \ldots \ldots \ldots \ldots \ldots \ldots \ldots, 104$ 
Aythya americana (Redhead) $\ldots \ldots \ldots \ldots \ldots \ldots \ldots \ldots,{ }_{48}^{\text {PAGE }}$ marila (Common Scaup) $\ldots \ldots \ldots \ldots \ldots \ldots \ldots, 50$

" vallisneria (Canvasback) .................... 48

Balearica pavonina (Crowned Crane). (Plate 34, Fig. 197) Bæolophus bicolor (Tufted Titmouse)................. Bee-eater, European (Merops apiaster). (Plate 9, Fig. 42) Bell-bird, Naked-throated (Chasmorhynchus nudicollis) (Plate 1o, Fig. 48)

94 184 145

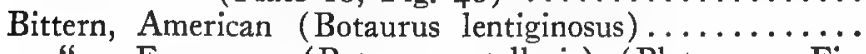
“ European (Botaurus stellaris).(Plate 33, Fig.

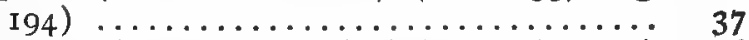

Blackbird, European (Merula merula). (Plate I I, Fig. 54) 196 “ Red-winged (Agelaius phoniceus) .......... 192

Blackcap (Sylvia atricapilla).........(Plate I3, Fig. 72) 201

Bluebird (Sialia sialis) ...................... 199

Blue-throat (Cyanecula cyanecula).... (Plate I2, Fig. 63) I98

Bobolink (Dolichonyx oryzivorus) ............... 192

Bob White (Colinus virginianus) $\ldots \ldots \ldots \ldots \ldots \ldots \ldots$ 91

Bonasa umbellus (Ruffed Grouse)................ 88

" " togata (Canada Grouse)............ 89

Botaurus lentiginosus (American Bittern) .......... 37

stillaris (European Bittern) ............ 37

Brambling (Fringilla montifringilla).(Plate 18 , Fig. 104) 217

Bránta bernicla, (Brant Goose)..... (Plate 34, Fig. 199) 52

" canadensis (Canada Goose)................ 52

“ migricans (Black Brant)................. 52

Brewster, William ...................... ${ }_{126}$

Broadbills .......................... 173

Buceros bicornis (Indian Hornbill).... (Plate 9, Fig. 39) I46

Bubo virginianus (Great Horned Owl)............. ${ }_{15} 8$

Bullfinch (Pyrrhula pyrrhula)....... (Plate I6, Fig. 9I) 218

Bunting, Corn (Miliaria miliaria)...(Plate I5, Fig. 86) 222

“ Indigo (Cyanospiza cyanea) ............... 220

“ Lapland (Calcarius lapponicus).. (Plate I5, Fig.

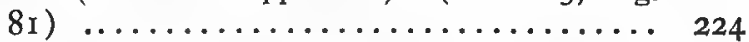

“ Reed (Emberiza schæniclus). (Plate I6, Fig. 88) 227

“ Snow (Passerina nivalis).... (Plate I6, Fig. 89) 221

Bustard, Great (Otis tarda)........ (Plate 30, Fig. I69) IOO

“ Little (Tetrax tetrax).... (Plate 29, Fig. I62) 99

Buteo buteo (European Buzzard)..... (Plate 4, Fig. 16) 62 
Buteo borealis (Red-tailed Hawk).............. 62

" lineatus (Red-shouldered Hawk) .............. 62

Buzzard, European (Buteo buteo)......(Plate 4, Fig. I6) 62

“ Turkey (Cathartes aura) ...(Plate 4I, Fig. 243) 76

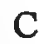

Cacabis saxatilis (Red-legged Rock Partridge). (Plate 25,

Fig. I 45$) \ldots \ldots \ldots \ldots \ldots \ldots \ldots \ldots \ldots \ldots$. . . . . . . . . . . . .

Cacatua galerita (Great Sulphur-crested Cockatoo)......

Calcarius lapponicus (Lapland Bunting)...(Plate I5, Fig. $8 \mathrm{I})$

Calidris arenaria (Sanderling)...... (Plate 32, Fig. 188) Callipepla squamata (Scaled Partridge)............. Callocephalum galeatum (Helmet Cockatoo) . (Plate 8, Fig. 36)

Calospiza tatao (Paradise Tanager).. (Plate I9, Fig. I13)

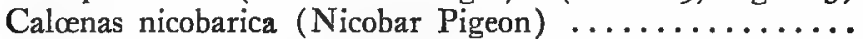

Campephilus principalis (Ivory-billed Woodpecker). (Plate 6, Fig. 25)

Canary (Serinus canarius) .......... (Plate I8, Fig. I05)

Capercailzie (Tetrao urogallus) . (Plate 24, Figs. 138, 139) CAPRIMULGI

Caprimullgus europæus (European Nightjar).. (Plate I9, Fig. I I )

Caracara (Polyborus cherivay)...... (Plate 42, Fig. 242)

Cardinal (Cardinalis cardinalis)..... (Plate I 7, Fig. IOI)

Carduelis carduelis (European Goldfinch)...(Plate I7, Fig. 98)

Cariama cristata (Seriema)......... (Plate 42, Fig. 245)

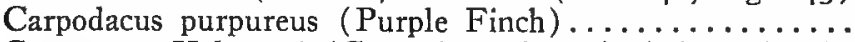

Cassowary, Helmeted (Casuarius galeatus). (Plate 28, Fig.

I59) ...................... 2, 3

Casuarius galeatus (Helmeted Cassowary). (Plate 28, Fig. I 59)

68

224

213

94

219

2,3

Catbird (Galeoscoptes carolinensis) ............ 188

Catharista urubu (Black Vulture) ............... 77

Cathartes aura (Turkey Vulture)...(Plate 4I, Fig. 243) 76

" californianus (California Condor) ......... 75

Cepphus grylle (Guillemot)............... 121

Certhia familiaris (European Tree-creeper). (Plate 21, Fig.

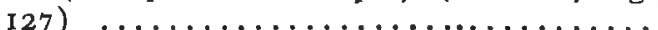


Certhia familiaris americana (American Brown Creeper)..

Ceryle alcyon (American Kingfisher).............. I 144

Chacalacca (Ortalis vetula maccalli).............. 79

Chapman, Frank M.................42, 159, 205

Chaffinch (Fringilla cælebs)........ (Plate 17, Fig. 97) 216

Chapparal-cock (Geococcyx californianus). (Plate 4I, Fig.

CHARADRIIFORMES 246) $\ldots \ldots \ldots \ldots \ldots \ldots \ldots \ldots \ldots \ldots \ldots$ I4I

Charadrius dominicus (Golden Plover). (Plate 30, Fig. I 70$) \ldots \ldots \ldots \ldots \ldots \ldots \ldots \ldots \ldots \ldots \ldots \ldots \ldots \ldots$ I02

Chasmorhynchus nudicollis (Bell-bird). (Plate Io, Fig. 48) 174

Chat, Yellow-breasted (Icteria virens) ............. 205

Chelidonaria urbica (House-martin)...(Plate I9, Fig. I09) I79

Chen hypoboreus (Snow Goose)... (Plate 34, Fig. 200) 52

Chewink (Pipilo erythrophthalmus) ............... 220

Chickadee (Parus atricapillus) ................. I 84

Chloris chloris (Greenfinch)......... (Plate I6, Fig. 90) 212

Chordeiles virginianus (Nighthawk) .............. 150

Chrysolophus pictus (Golden Pheasant).(Plate 25, Figs. I 46, I 47$) \ldots \ldots \ldots \ldots \ldots \ldots \ldots \ldots \ldots \ldots \ldots \ldots \ldots \ldots$

Chuck-will's-widow (Antrostomus carolinensis) ........ I50

Ciconia ciconia (European White Stork).. (Plate 33, Fig.

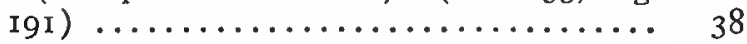

CICONIÆ ........................... 23

Cinclus cinclus (European Water Ouzel). (Plate IO, Fig.

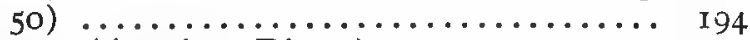

" mexicanus (American Dipper) ............. 195

Circus hudsonius (American Harrier) .............. 6I

" cyaneus (European Hen Harrier) (Plate 4, Fig. I5) 6I

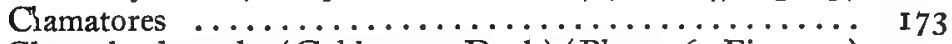

Clangula clangula (Golden-eye Duck) (Plate 36, Fig. 213) 47

Coccyges americanus (Yellow-billed Cuckoo) ......... I39

Cockatoo, Great Black (Microplossus aterrimus)........ 137

Helmet (Callocephalon galeatum). (Plate 8, Fig.

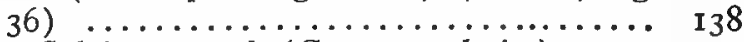

“ Great Sulphur-crested (Cacatua galerita)...... 137

Cock-of-the-rock (Rupicola rupicola). (Plate 19, Fig. I I2) 173

Cocothraustes cocothraustes (Hawfinch).(Plate 14, Fig. 77) 213

Colaptes auratus luteus (Common Flicker).......... I70

Colæus monedula (Jackdaw)........(Plate 19, Fig. II4) 231

Colinus virginianus (Bob White) $\ldots \ldots \ldots \ldots \ldots \ldots$ 91

Colomba ænas (Stock Dove)......... (Plate 22, Fig. I3I) 129

livia (Rock Dove)......... (Plate 23, Fig. I35) 129 
Colomba livia var. (Pouter Pigeon).. (Plate 23, Fig. 134) COLUMB fasciata (Ban'd-tailed Pigeon)............ I3 I

COLUMBL ............................. 124

Columbigallina passerina terrestris (Ground Dove)...... I30

Colymbus auritus (Horned Grebe) ............ I7

cristatus (Great Crested Grebe). (Plate 39, Fig. 232)

" fluviatilis (Little Grebe)... (Plate 40, Fig. 237) 16 16

Condor, California (Cathartes californianus)...........

" South American (Sarcoramphus gryphus). (Plate I, Fig. I ) ................. 74

Contopus virens (Wood Pewee)

Conurus carolinensis (Carolina Paroquet)... (Plate 7, Fig.

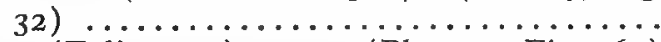

Coot, European (Fulica atra) ....... (Plate 29, Fig. I67)

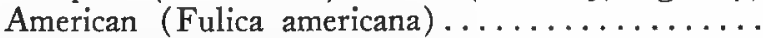

Coquimbo (Speotyto cunicularia hypogæa)

CORACIÆ

Coracius garrulus (European Roller)... (Plate 9, Fig. 43)

Cormorant, Common (Phalacrocorax carbo). (Plate 37, Fig. 218)

6

Harris's Phalacrocorax harrisi).

75

74
176

I35

99

99

160

142

142

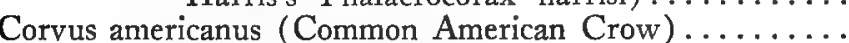

" corone (Carrion Crow) ............................

" corax (European Raven).... (Plate 20, Fig. I16)

" corax sinuatus (American Raven) ............

" ossifragus (Fish Crow) .................

Coturnix coturnix (Common European Quail) .. (Plate 24,

Coues, Elliott

Fig. I 4 I $\ldots \ldots \ldots \ldots \ldots \ldots \ldots \ldots \ldots \ldots$

Cowbird (Molothrus ater)

Crake, Carolina (Porzana carolina) .............. 97

" Little (Zapornia parva)..... (Plate 29, Fig. I64) 97

“ Spotted (Porzana porzana)...(Plate 29, Fig. 166) 97

Corncrake (Crex crex) .............(Plate 30, Fig. 168) 97

Crane, Crowned (Balearica pavonina) . (Plate 34, Fig. 197) 94

" Demoiselle (Anthropoides virgo)........... 94

" Common European (Grus grus). (Plate 29, Fig. 161 ) ......................... 93

" Little Brown (Grus canadensis) ........... 94

“ Sandhill (Grus mexicana) ............... 94

" Whooping (Grus americana)............ 94

Creeper, American Brown (Certhia familiaris americana).. I86 
Creeper, European Tree (Certhia familiaris)..(Plate 2I,

Creepers

Wall (Tichodroma muraria).(Plate 2I, Fig. I26)

Crossbill, American Red (Loxia curvirostra minor)........

187 186

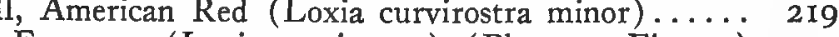

Crotrostra).(Plate I5, Fig. 79)

219

139

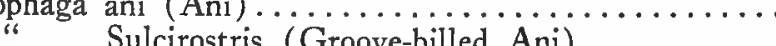

140

Crow, Common American (Corvus americanus) ........ 228

" Carrion (Corvus corone) ................... 228

" Fish (Corvus ossifragus) ..................... 228

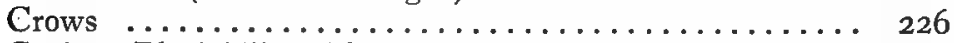

Cuckoo, Black-billed (Coccyzus erythrophthalmus)....... 139

" Common European (Cuculus canorus). (Plate 7, Fig. 30) $\ldots \ldots \ldots \ldots \ldots \ldots \ldots \ldots \ldots \ldots \ldots \ldots \ldots \ldots \ldots$

“ Yellow-billed (Coccyzus americanus) ........... 139

CUCULI ........................... I 33

Cuculus, canoris (European Cuckoo)...(Plate 7, Fig. 30) 139

Curassow, Globose (Crax globicera)..(Plate 4I, Fig. 244) 79

Curlew, Eskimo (Numenius borealis) .............. In 3

“ European (Numenius arquatus).(Plate 3I, Fig.

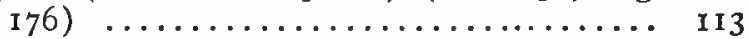

" Hudsonian (Numenius hudsonicus) .......... II3

“ Long-billed (Numenius longirostris) .......... 112

Crymophilus rulicarius (Wilson's Phalarope)......... I I 3

Cyanecula cyanecula (Blue-throat)... (Plate I2, Fig. 63) I98

Cyanocitta cristata (American Blue Jay)............. 230

Cyanospeza cyanea (Indigo Bunting) $\ldots \ldots \ldots \ldots \ldots \ldots$. 220

Cygnus olor (European Mute Swan). (Plate 35, Fig. 201) 54

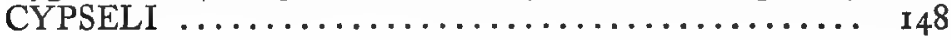

Dabchick (Colymbus fluviatilis)..... (Plate 40, Fig. 237) I6

Dacelo gigas (Giant Kingfisher)............... I43

Dafila acuta (Pintail Duck)......... (Plate 35, Fig. 205) 47

Darter (Anhinga anhinga).......... (Plate 38, Fig. 222) 25

Daulius luscinia (Nightingale).......(Plate I2, Fig. 59) 198

Didus ineptus (Dodo) ....................... I26

Diomeda exulans (Wandering Albatross) ........... 19

melanophrys (Black-browed Albatross). (Plate 38,

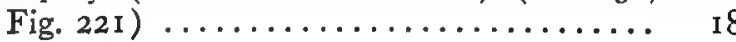


Colomba livia var. (Pouter Pigeon).. (Plate 23, Fig. 134)

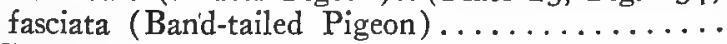
COLUMBÆ

Columbigallina passerina terrestris (Ground Dove).......

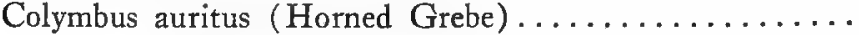
cristatus (Great Crested Grebe). (Plate 39, Fig. 232)

" fluviatilis (Little Grebe)...(Plate 40, Fig. 237)

Condor, California (Cathartes californianius) ..........

"South American (Sarcoramphus gryphus). (Plate

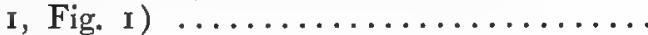
Contopus virens (Wood Pewee)

Conurus carolinensis (Carolina Paroquet)... (Plate 7, Fig. 32)

Coot, European (Fulica atra)....... (Plate 29, Fig. 167)

Coracius garrulus (European Roller)... (Plate 9, Fig. 43)

Cormorant, Common (Phalacrocorax carbo). (Plate 37, Fig. 218)

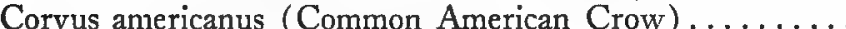

" corone (Carrion Crow) ............... 228

" corax (European Raven).... (Plate 20, Fig. I I6)

" corax sinuatus (American Raven) ...........

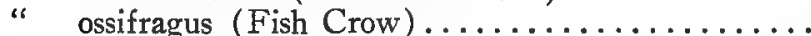

Coturnix coturnix (Common European Quail).. (Plate 24,

Coues, Elliott

$$
\text { Fig. I } 4 \text { I }) \ldots \ldots \ldots \ldots \ldots \ldots \ldots \ldots \ldots
$$

Cowbird (Molothrus ater)

195

Crake, Carolina (Porzana carolina).

" Spotted (Porzana porzana).. (Plate 29, Fig. 166) 97

Corncrake (Crex crex) ............(Plate 30, Fig. 168) 97

Crane, Crowned (Balearica pavonina). (Plate 34, Fig. 197) 94

" Demoiselle (Anthropoides virgo)..............

" Common European (Grus grus). (Plate 29, Fig.

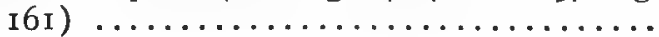

" Little Brown (Grus canadensis) ............

" Sandhill (Grus mexicana) .................

"Whooping (Grus americana) 
Creeper, European Tree (Certhia familiaris)..(Plate 2I, Fig. 127) ...................... 186

"Wall (Tichodroma muraria).(Plate 21, Fig. 126) 187

Creepers ............................ 186

Crossbill, American Red (Loxia curvirostra minor)..... 219

" European (Loxia curvirostra). (Plate I5, Fig. 79) 219

Crotophaga ani (Ani) ...................... I 139

Sulcirostris (Groove-billed Ani) .......... I4O

Crow, Common American (Corvus americanus) ........ 228

"Carrion (Corvus corone) ................... 228

" Fish (Corvus ossifragus) ..................... 228

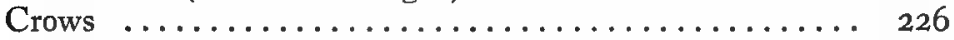

Cuckoo, Black-billed (Coccyzus erythrophthalmus)...... $\quad$ I39

" Common European (Cuculus canorus). (Plate 7,

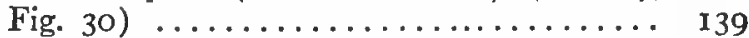

“ Yellow-billed (Coccyzus americanus) ......... 139

CUCULI

133

Cuculus, canoris (European Cuckoo)...(Plate 7, Fig. 30) 139

Curassow, Globose (Crax globicera).. (Plate 4I, Fig. 244) 79

Curlew, Eskimo (Numenius borealis) .............. II

European (Numenius arquatus). (Plate 3I, Fig. 176) $\ldots \ldots \ldots \ldots \ldots \ldots \ldots \ldots \ldots \ldots \ldots \ldots \ldots \ldots \ldots \ldots$

" Hudsonian (Numenius hudsonicus) .......... II3

“ Long-billed (Numenius longirostris) ........... II

Crymophilus rulicarius (Wilson's Phalarope).......... II

Cyanecula cyanecula (Blue-throat)...(Plate I2, Fig. 63) 198

Cyanocitta cristata (American Blue Jay)............ 230

Cyanospeza cyanea (Indigo Bunting) ............. 220

Cygnus olor (European Mute Swan). (Plate 35, Fig. 201) 54

CYPSELI .......................... ${ }_{148}^{54}$

Dabchick (Colymbus fluviatilis)..... (Plate 40, Fig. 237) I6

Dacelo gigas (Giant Kingfisher)............... I 43

Dafila acuta (Pintail Duck)........ (Plate 35, Fig, 205) 47

Darter (Anhinga anhinga).......... (Plate 38, Fig. 222) 25

Daulius luscinia (Nightingale).......(Plate I2, Fig. 59) I98

Didus ineptus (Dodo) .................... 126

Diomeda exulans (Wandering Albatross).......... I9

melanophrys (Black-browed Albatross). (Plate 38, Fig. 221 $\ldots \ldots \ldots \ldots \ldots \ldots \ldots \ldots \ldots \ldots \ldots \ldots \ldots \ldots$ 
Dipper, American (Cinclus mexicanus) ............ 195 European (Cinclus cinclus).... (Plate Io, Fig. 50) 195

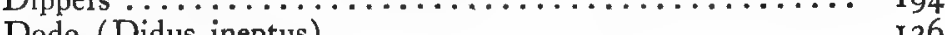

Dodo (Didus ineptus) ...................... 126

Dolichonyx, oryzivorus (Bobolink) ............. 192

Dove, Ground (Columbigallina passerina terrestris)..... I30

" Mourning (Zenaida macroura) ............. 130

“ Ring (Streptopelia risoria).... (Plate 22, Fig. 130) 128

“ Rock (Columba livia)........ (Plate 23, Fig. 135) I29

"Stock (Columba ænas)......... (Plate 22, Fig. I3I) I29

“ Turtle (Turtur turtur)...... (Plate 23, Fig. 137) 127

" White-winged (Melopella leucoptera)........... I3 I

Dovekie (Alle alle) ............. (Plate 40, Fig. 236) I23

Dryobates minor (Lesser Spotted Woodpecker).(Plate 6, Fig. 27) ...................... 169

Dromæus novæhollandiæ (Emu)...$\ldots \ldots \ldots \ldots \ldots$ I

Duck, Aylesbury.......................... 49

" Black (Anas obscura)................... 48

“ Canvasback (Aythya vallisneria) .............. 48

“ Eider (Somateria mollissima). (Plate 35, Fig. 206) 46

“ Golden-eye (Clangula clangula)... (Plate 36, Fig.

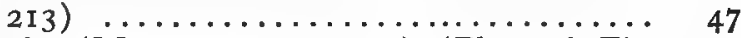

“ Goosander (Merganser merganser). (Plate 36, Fig.

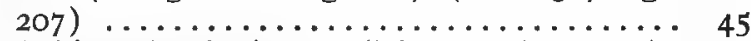

Mallard (Anas boschus)......(Plate 35, Fig. 203) 47

Mandarin (Aid galericulata) ............... 49

Muscovy .......................... 49

Old Squaw (Harelda hyemalis) . (Plate 36, Fig. 208) 47

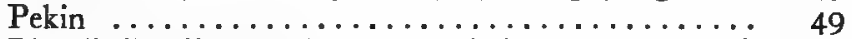

Pintail (Dafila acuta)........ (Plate 35, Fig. 205) 47

Redhead (Aythya americana)............... 48

Scaup (Aythya marila) ................... 50

“ Scoter, Velvet (Oidemia fusca).... (Plate 36, Fig.

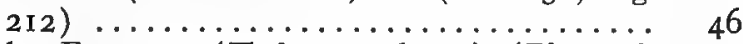

" Sheldrake, European (Tadorna tadorna).(Plate 36, Fig. 209) ...................... 50

“Smew (Mergus albellus).... (Plate 36, Fig. 210) 46

“ Tufted, (Nyroca fuligula) .... (Plate 36, Fig. 21 I) 47

“ Teal, Blue-winged (Querquedula discors)........ 48

"Teal, European (Nettion crecca). (Plate 35, Fig.

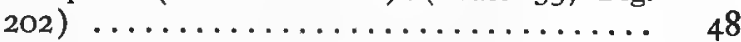

“ Teal, Green-winged (Nettion carolinensis) ...... 48

“ Widgeon (Mareca penelope)..(Plate 35, Fig. 204) 47 
Duck, Wood (Aix sponsa)

Eagle, Bald (Haliaëtus lucocephalus) ....... (Frontispiece) 64 Golden (Aquila chrysaëtus)....... (Plate 2, Fig. 8) 63

" Harpy (Thrasaëtus harpyia).. (Plate 42, Fig. 24I) 66

“ Kamchatka Sea (Haliaëtus pelagicus) ........... 65

“ Spotted (Aquila maculata).... (Plate 3, Fig. Io) 63

"White-tailed (Haliaëtus albicilla). (Plate 3, Fig. 9) 64

Ectopistes migratorius (Passenger Pigeon). (Plate 22, Fig. 133) $\ldots \ldots \ldots \ldots \ldots \ldots \ldots \ldots \ldots \ldots \ldots \ldots \ldots \ldots \ldots, \quad 126$

Egret, American (Herodias egretta) ............... 36

" Little (Garzetta candidissima).............. 35

" Great White (Herodias alba). (Plate 33, Fig. 193) 35

" Snowy (Egretta candidissima) .............. 35

Elanus leucurus (White-tailed Kite) .............. 60

Elanoides forficatus (Swallow-tailed Kite) ........... 60

Ereunetes pusillus (Semipalmated Sandpiper)......... I09

Erolia ferruginea (Curlew Sandpiper) ............. I09

Emberiza schæniclus (Red Bunting).. (Plate I6, Fig. 88) 224

" hortulana (Ortolan)....... (Plate I6, Fig. 87) 223

Emu, Common (Dromæus novæhollandiæ) .......... I

Eurylæmidæ (Broadbills)................. I 173

$\mathbf{F}$

Falco islandus (Gyrfalcon).......... (Plate 2, Fig. 7) 7I

" peregrinus anatum (Duck Hawk)............ 7 I

Finch, Purple (Carpodacus purpureus) …........ 219

Finches .......................... 21

Flamingo, American (Phænicopterus ruber)......... 42 European (Phænicopterus roseus). (Plate 33, Fig. 189) ................... 42

Flicker, Common (Colaptes auratus luteus) ......... I 70

Flycatcher, Great Crested (Myiarchus luteiventris) ..... I76

" Pied (Muscicapa atricapilla) ............. 180

" Spotted (Muscicapa grisola).(Plate Io, Fig. 47) $\quad$ I80

Flycatchers, American...................... I74

European $\ldots \ldots \ldots \ldots \ldots \ldots \ldots \ldots \ldots$ I 80

Fowl, Domestic (Gallus gallus, var.). (Plate 27, Fig. I56) 86 
Fratercula arctica (Puffin)........ (Plate 39, Fig. 233) PAGE

Frigate-bird (Fregata aquila) ......... (Plate 37, Fig. 219) 122 Fringilla montifringilla (Brambling). (Plate I8, Fig. I04) cælebs (Chaffinch) ......... (Plate I7, Fig. 97) Fulica americana (American Coot)............... $"$ atra (European Coot)........ (Plate 29, Fig. 167)

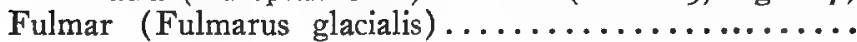

Galeoscoptes carolinensis (Catbird) ............ I88 Galerida cristata (Crested Lark)..... (Plate 14, Fig. 76) 2 I I GALLIFORMES .................... 78 Gallinago gallinago (European Snipe). (Plate 31, Fig. I 78) I05 " gallinula (Jack Snipe) ............... 105 " media (Great Snipe)......(Plate 3 I, Fig. I 79) 105 Gallinula chloropus (Moor-hen)....(Plate 29, Fig. I65) 99 Gallinule, Florida (Gallinula galeata) ............. 98 Purple (Ionornis martinica) ........... 98

Gallus gallus, var. (Domestic Fowl). (Plate 27, Fig. I56) 86 " ferrugineus (Jungle Fowl) ............... 85

Gannet, Common (Sula bassana)..... (Plate 37, Fig. 217) 27 Garrulus glandarius (European Jay). (Plate 20, Fig. II9) 230 Garzettá candissima (Little Egret).............. 35 Gavia arctica (Black-throated Loon) . (Plate 39, Fig. 231) I4 " imber (Common Loon)................ 15 " lumme (Red-throated Loon)............... I6 Geococcyx californianus (Road-runner) (Plate 4I, Fig. 246) I4I Gennæus nycthemerus (Silver Pheasant). (Plate 26, Fig. I5 I)

Glareola pratincola (Pratincole)..... (Plate 31, Fig. I75) Goldcrest (Regulus regulus)......... (Plate I3, Fig. 69) Goldfinch, American (Astragalinus tristis) ............

" European (Carduelis carduelis). (Plate I7, Fig. Goosander (Merganser merganser) ... (Plate 36, Fig. 207) 213 Goose, Black Brant (Branta migricans)........... 52

" Brant (Branta bernicla)...... (Plate 34, Fig. I99) 52

" Canada (Branta canadensis) ................ 52

“ Grey-lag (Anser anser) ...... (Plate 34, Fig. 198) 52

“Snow (Chen hyperboreus) ... (Plate 34, Fig. 200) 52

"Solan (Sula bassana)........ (Plate 37, Fig. I 7) 27

"White-fronted (Anser albifrons gambeli)....... 53 
Goshawk, American (Accipter atricapillus)........... 6I

European (Astur palumbarius). (Plate 4, Fig. 14) $\ldots \ldots \ldots \ldots \ldots \ldots \ldots \ldots \ldots \ldots \ldots \ldots \ldots \ldots \ldots$ 6r

Goura coronata (Crowned Pigeon). (Plate 23, Fig. I36) I28

Grackle, Boat-tailed (Megaquiscalus major) .......... 193

Purple (Quiscalus quiscula) .............. I93

Grebe, Great Crested (Colymbus cristatus). (Plate 39, Fig. 232)

“ Horned (Colymbus auritus) ................ I 7

“ Little (Colymbus, fluviatilis).(Plate 40, Fig. 237) I6

" Pied-billed (Podilymbus podiceps)........... 17

Greenfinch (Chloris chloris) ........... (Plate 16, Fig. 90) 212

Greenshank (Totanus nebularius).... (Plate 31, Fig. I80) IO7

Groesbeck, Pine (Pinicola enucleator)..(Plate 16, Fig. 92) 218

Grouse, Black (Lyrurus tetrix)...... (Plate 24, Fig. I42) 90

Canada (Bonasa umbellus togata) ............ 89

“ Dusky (Dendragapus obscurus) ............ 89

“ Hazel (Tetrastes bonasia)..(Plate 24, Fig. 140) 9I

"Ptarmigan, Alpine (Lagopus mutus). (Plate 24, Fig. I43) ..................... 89

“ Ruffed (Bonasa umbellus) ................ 88

" Sage (Centrocercus urophasianus)........... 89

" Sharp-tailed (Pediæcetes phasianellus) ......... 89

GRUIFORMES

93

Grus canadensis (Little Brown Crane) ............ 94

" grus (European Crane)......(Plate 29, Fig. I6I) 93

" americana (Whooping Crane)................ 94

" mexicana (Sandhill Crane) ................... 94

Guan (Ortalis vetula maccalli) ................. 79

Guara alba (White Ibis).$\ldots \ldots \ldots \ldots \ldots \ldots \ldots \ldots$ 4I

" rubra (Scarlet Ibis) ................... 40

Guillemot (Cepphus grylle)................. I2I

Guinea-fowl (Numida meleagris).... (Plate 27, Fig. 154) 81

" Vulturine (Acryllium vulturinum)......... 82

Gull, Black-headed (Larus ridibundus). (Plate 39, Fig.

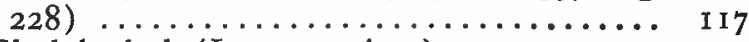

“ Great Black-backed (Larus marinus) .......... II7

"Herring (Larus argentatus)... (Plate 38, Fig. 223) II6

“ Kittiwake (Rissa tredactyla)..... (Plate 38, Fig. 225) II

"Laughing (Larus atricilla).................... II8

“ Mew (Larus canus).......... (Plate 38, Fig. 224) II 7

Gypaëtus barbatus (Lammegeier)........(Plate I, Fig.4) 73

Gypagus papa (King Vulture)......... (Plate 2, Fig. 5) 74 
Gyps fulvus (Griffon Vulture) .......... (Plate I, Fig 3

PAGE

Gyrfalcon (Falco islandus) ...........(Plate 2, Fig. 7) $7 \mathbf{I}$

\section{H}

Hæmatopus bachmani (Black Oyster-catcher) .......... II2

4 palliatus (American Oyster-catcher) .......... I I 2

Haliaëtus albicilla (White-tailed Eagle).(Plate 3, Fig. 9) 64

" lucocephalus (Bald Eagle)....(Frontispiece).. 64

" pelagicus (Kamachatka Sea-eagle)......... 65

Haploderma Narina (African Trogon). (Plate 9, Fig. 44) 165

Harelda hycmalis (Old Squaw Duck). (Plate 36, Fig. 208) 47

Hawfinch (Cocothraustes cocothraustes). (Plate 14, Fig. 77) 213

Hawk, American Harrier (Circus hudsonius) ......... 6 I

" European Hen Harrier (Circus cyaneus). (Plate 4,

Fig. I 5$) \ldots \ldots \ldots \ldots \ldots \ldots \ldots \ldots \ldots$ 6I

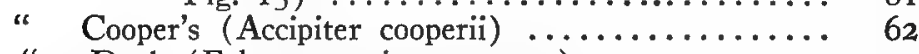

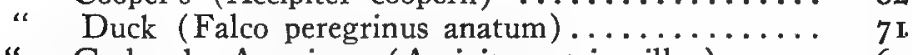

“ Goshawk, American (Accipiter atricapillus)..... 6

“ Goshawk, European (Astur palumbarius). (Plate 4,

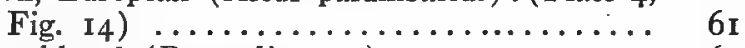

" Red-shouldered (Buteo lineatus) ............. 62

" Red-tailed (Buteo borealis) .............. 62

" Sharp-shinned (Accipter velox) ............... 62

“ American Sparrow (Falco sparverius) ........... 70

“ European Sparrow (Accipiter nisus). (Plate 3, Fig.

I2) $\ldots \ldots \ldots \ldots \ldots \ldots \ldots \ldots \ldots \ldots$ 6I

Heliactin bilopha (Double-crested Humming Bird). (Plate

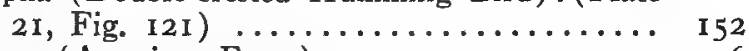

Herodias egretta (American Egret) .............. 36

" alba (Great White Egret) .. (Plate 33, Fig. 193) 35

Heron, European (Ardea cinerea) ....(Plate 33, Fig. I92) 33

" Great Blue (Ardea herodias).............. 33

" Great White (Ardea occidentalis) ............ 34

“ Little Green (Butorides virescens) ........... 34

“ Louisiana (Hydranassa tricolor ruficollis) ........ 35

"Night, Black-crowned (Nycticorax nycticorax nævius) .................... 35

“ Night, Yellow-crowned (Nyctanassa violaceus)... ... 35

"Ward's (Ardea herodias wardi) ............ 33

Himantopus himantopus (European Stilt). (Plate 30, Fig.

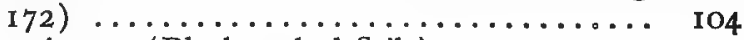

" mexicanus (Black-necked Stilt) ......... I04 
Hirundo rustica (European Barn Swallow). (Plate 18, Fig. I08)

Hoopoe, Common (Upupa epops).... (Plate 22, Fig. I29)

Hornbill, Indian (Buceros bicornis).... (Plate 9, Fig. 39)

Humming-bird, Coquette (Lophornis ornata.. (Plate 2I,

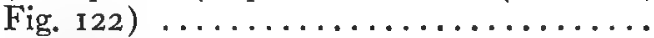

“ Double-crested (Heliactin bilopha)..... (Plate

21, Fig. I2I) $\ldots \ldots \ldots \ldots \ldots \ldots \ldots \ldots \ldots \ldots \ldots \ldots \ldots$

“ Fire-tailed (Lesbia sparganura)..... (Plate 2I,

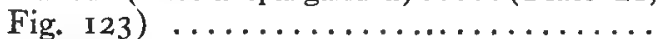

“ Racquet-tailed (Spathura underwoodi).. (Plate

2I, Fig. I25) ................. 153

“ Ruby-throated (Trochilus colubris) ....... 154

“ Topaz (Topaza pella).... (Plate 2I, Fig. I24) I53

Hylocichla fuscescens (Wilson's Thrush) ............ I 120

mustelina (Wood Thrush) $\ldots \ldots \ldots \ldots \ldots \ldots$. 199

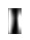

Ibis, Glossy (Plegadis autumnalis) $\ldots \ldots \ldots \ldots \ldots \ldots \ldots$ 4I

"Sacred (Ibis æthiopica)......... (Plate 34, Fig. I96) 40

“ Scarlet (Guara rubra) ...................... 40

"White (Guara alba)...................... $4 \mathbf{1}$

"Wood (Tantalus loculator).................. 40

Icteria virens (Yellow-breasted Chat) $\ldots \ldots \ldots \ldots \ldots \ldots \ldots, 205$

Icterus galbula (Baltimore Oriole) $\ldots \ldots \ldots \ldots \ldots \ldots$ I9I

Ictinia mississippiensis (Mississippi Kite) $\ldots \ldots \ldots \ldots \ldots$ 6o

IMPENNES $\ldots \ldots \ldots \ldots \ldots \ldots \ldots \ldots \ldots \ldots \ldots \ldots$ I4

Ionornis martinica (Purple Gallinule) $\ldots \ldots \ldots \ldots \ldots \ldots .98$

Iridoprocne bicolor (Tree Swallow) $\ldots \ldots \ldots \ldots \ldots \ldots, 180$

Jabiru (Mycteria americana)................. 39

Jacana, Mexican (Jacana spinosa)............... I1

Jack'daw (Colæus monedula)........ (Plate I9, Fig. I14) 231

Jæger, Parasitic. (Stercorarius parasiticus). (Plate 38, Fig. 226) $\ldots \ldots \ldots \ldots \ldots \ldots \ldots \ldots \ldots \ldots \ldots \ldots \ldots \ldots \ldots$ I2I

Jay, American Blue (Cyanocitta cristata) .......... 230

"Canada (Perisoreus canadensis) $\ldots \ldots \ldots \ldots \ldots \ldots$ 23I

“ European (Garrulus glandarius) . (Plate 20, Fig. 119) 230

Laughing Jackass (Dacelo gigas) .............. 143

Junco (Junco hyemalis) $\ldots \ldots \ldots \ldots \ldots \ldots \ldots \ldots \ldots, 221$ 
Jungle-fowl (Gallus ferrugineus) ............. 85 Jynx torquilla (Wryneck).......... (Plate 7, Fig. 31) I70

Kakapo (Stringops habroptilus) $\ldots \ldots \ldots \ldots \ldots \ldots \ldots, 138$

Kea (Nestor notabilis) .................. 137

Kestrel (Cerchneis tinnunculus) ......(Plate 3, Fig. I I) 70

Killdeer (Oxyechus vociferus) ................. 103

Kingbird (Tyrannus tyrannus) $\ldots \ldots \ldots \ldots \ldots \ldots \ldots \ldots$ I75

Kingfisher, Belted (Ceryle alcyon) ............. 144

Common European (Alcedo ispida).(Plate 9,

Fig. 40) .................... I44

“ Giant (Dacelo gigas) ................ 143

Kinglet, Golden-crowned (Regulus satrapa) ........ 202

Ruby-crowned (Regulus calendula) ........ 202

Kite, European Red (Milvus milvus)... (Plate 4, Fig. I7) 60

"Mississippi (Ictinia mississippiensis) .......... 60

“ Swallow-tailed (Elanoides forficatus) ......... 6o

“White-tailed (Elanus leucurus) ............. 60

Kittiwake (Rissa tridactyla)........(Plate 38, Fig. 225) II7

Kiwi (Apteryx mantelli).........(Plate 28, Fig. 160) 7

Knot (Tringa canutus).........(Plate 32, Fig. I87) I I0

L

Lagopus mutus - (Alpine Ptarmigan) .. (Plate 24, Fig. 143) 89

Lammergeier (Gypaëtus barbatus)...... (Plate I, Fig. 4) 73

Lanius borealis (Northern Shrike) ............ I $8 \mathrm{I}$

" excubitor (Great Grey Shrike)..(Plate IO, Fig. 46) I81

“ ludovicianus (Loggerhead Shrike) ........... 182

" collurio (Red-backed Shrike)..(Plate Io, Fig. 45) I82

Lapwing (Vanellus vanellus)....... (Plate 30, Fig. I7I) I03

Lark, Horned (Otocoris alpestris) ............... 2II

" Prairie Horned (Otocoris alpestris praticola)..... 212

“ Crested (Galerida cristata).... (Plate I4, Fig. 76) 2 I I

" Skylark (Alauda arvensis)......(Plate I4, Fig. 74) 210

"Wood (Alauda arborea)......(Plate 14, Fig. 75) 2 I I

Larks ............................... 210

Larus atricilla (Laughing Gull) ................ I18

" argentatus (Herring Gull) ... (Plate 38, Fig. 223) I I6

“ canus (Mew Gull)......... (Plate 38, Fig. 224) II7

" marinus (Great Black-backed Gull) ......... I I7

" ridibundus (Black-headed Gull)..(Plate 39, Fig.

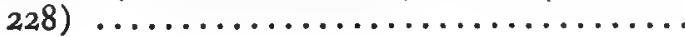


Leptoptilus argala (Indian Adjutant Stork)

PAGE crumenifer (African Adjutant Stork).. (Plate 34, Fig. 195) ...................... Lesbia Sparganura (Fire-tailed Hummingbird).. (Plate 2I, Fig. 123)

Linnet (Linota cannabina)........... (Plate $r 7$, Fig. Ioo)

Longspur, Lapland (Calcarius lapponicus).... (Plate 15, Fig. 8I)

Loon, Black-throated (Gavia arctica). (Plate 39, Fig. 23I)

224

"Common (Gavia imber) ....................

" Red-throated (Gavia lumme)

I4

I5

16

Lophophanes cristatus (Crested Tit) .. (Plate I5, Fig. 82) 183

Lophornis ornata (Coquette Hummingbird).... (Plate 2I, Fig. 122) ..................... ${ }_{152}$

Lophophorus impeganus (Impeyan Pheasant).......... 83

Lophortyx californicus (California Partridge)........... 92 gambelii (Gambel Partridge)... (Plate 4I, Fig.

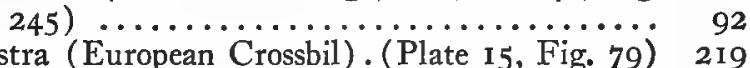

$\underset{\text { "Loxia curvirostra (European Crossbil). (Plate 15, Fig. 79) }}{219}$

Lunda cirrhata (Tufted Puffin) $\ldots \ldots \ldots \ldots \ldots \ldots \ldots . . .122$

Lyrurus tetrix (Black Grouse)... (Plate 24, Fig. 142).. 90

Lyre-bird (Menura superba).........(Plate 14, Fig. 73) 177

\section{M}

Macaw, Blue and Yellow (Ara ararauna)..(Plate 8, Fig. 34)

" Hyacinthine (Ara hyacinthina)

"Red and Blue (Ara macao).... (Plate 8, Fig. 35)

Magpie, American (Pica pica hudsonia) (.............

I36

European (Pica pica)...... (Plate 20, Fig. II5) 231

Man-o'-war Bird (Fregata aquila)... (Plate 37, Fig. 219) 3I

Marabou (Leptoptilus crumenifer).. (Plate 34, Fig. 195) 38

Marecca penelope (Widgeon)....... (Plate 35, Fig. 204) 47

Marsh-Hen (Rallus crepitans) ................. 97

Martin, House (Chelidonaria urbica). (Plate I9, Fig. I09) I79

" Purple (Progne subis) .................... I80

“ Sand (Riparia riparia)....... (Plate 19, Fig.I Io) 179

Meadowlark (Sturnella magna) ................. 193

Megapodes $\ldots \ldots \ldots \ldots \ldots \ldots \ldots \ldots \ldots \ldots \ldots \ldots,{ }_{78}$

Megascops asio (Screech $\mathrm{Ow1}$ ) $\ldots \ldots \ldots \ldots \ldots \ldots \ldots$ I62

Megaquiscalus major (Boat-tailed Grackle) ......... 193 
Melanerpes erythrocephalus (Red-headed Woodpecker).... (Plate 7, Fig. 29) .................. 169

Meleagris gallopavo (Mexican Wild Turkey).. (Plate 27,

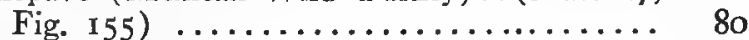

" ocellata (Honduras Turkey) ............ 8I

“ sylvestris (Eastern Wild Turkey) .......... 81

Melopsittacus undulatus (Grass Paroquet)...... (Plate 8,

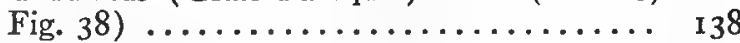

Melospiza cinerea melodia (Eastern Song Sparrow) ..... 216 Menura superba (Lyre-bird).........(Plate I4, Fig. 73) 177 Merganser, Hooded (Lophodytes cucullatus) .......... 46 merganser (Goosander).. (Plate 36, Fig. 207) 45

Mergus albellus (Smew)......... (Plate 36, Fig. 210) 46 Meropella leucoptera (White-winged Dove) ........ I3I Merops apiaster (European Bee-eater)...(Plate 9, Fig. 42) I45 Merula migratoria (American Robin) ............. 199 “ torquatus (Ring Ouzel) ............... 196

Microglossus atterrimus (Great Black Cockatoo)....... 137

Miliaria miliaria (Corn bunting).... (Plate I5, Fig. 86) 222

Milvus milvus (European Red Kite).... (Plate 4, Fig. I7) 60 Mockingbird (Mimus polyglottos).............. (Plate) I 88

Molothrus ater (Cowbird) $\ldots \ldots \ldots \ldots \ldots \ldots \ldots \ldots$ I9

Monticola saxatalis (Rock Thrush)...(Plate I2, Fig. 57) 196

Moor-hen (Gallinula chloropus).....(Plate 29, Fig. 165) 99

Motmot, Lesson Mexican .................... I 43

Motacilla alba (White Wagtail) ............... 208

" lugubris (Pied Wagtail)...(Plate II, Fig. 53) 208

" melanope (Grey Wagtail)..(Plate II, Fig. 52) 208

Murre (Uria lomvia)..............(Plate 40, Fig. 238) 122

Muscicapa grisola (Spotted Flycatcher). (Plate 10, Fig. 47) 180 Mycteria americana (Jabiru) $. . \ldots \ldots \ldots \ldots \ldots \ldots . .39$ Myarchus luteiventris (Great Crested Flycatcher) ...... I76

\section{$\mathbf{N}$}

Neophron percnopterus (Egyptian Vulture)....(Plate I,

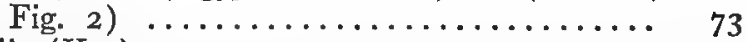

Nestor notabilis (Kea) $\ldots \ldots \ldots \ldots \ldots \ldots \ldots \ldots \ldots \ldots \ldots$ r. 134

Nettion crecca (European Teal)..... (Plate 35, Fig. 202) 48

" carolinensis (Green-winged Teal) ........... 48

Nightingale (Daulias luscinia)...... (Plate I2, Fig. 59) 198

Nightjar, Common European (Caprimulgus europæus).... (Plate 19, Fig. III) $\ldots \ldots \ldots \ldots \ldots \ldots$ 
Nighthawk (Chordeiles virginianus)

Noddy (Anous stolidus) .................... I I9

Nucifraga caryocatactes (Nutcracker). (Plate 20, Fig. II8) 23I

Numenius arguatus (European Curlew)...(Plate 3I, Fig.

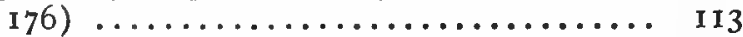

" borealis (Eskimo curlew) .............. II3

“ hudsonicus (Hudsonian) ................. I13

“ longirostris (Long-billed Curlew) ........... II2

Numida meleagris (Guinea Fowl)... (Plate 27, Fig. 154) 8I

Nutcracker (Nucifraga caryocatactes).(Plate 20, Fig. II8) 23I

Nuthatch, European (Sitta cæsia)... (Plate 21, Fig. 128) I85

" Red-breasted (Sitta canadensis) ............ I86

“ White-breasted (Sitta carolinensis) ......... 185

Nuthatches ............................ 184

Nyctea nyctea (Snowy Owl)........... (Plate 5, Fig. 23) 160

Nycticorax nycticorax nævius (Black-crowned Night

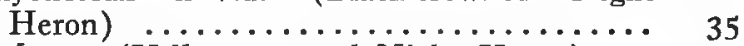

Nyctanassa violaceus (Yellow-crowned Night Heron)... 35

$\mathrm{O}$

Oceanodroma leucorhoa (Leach's Petrel).. (Plate 37, Fig.

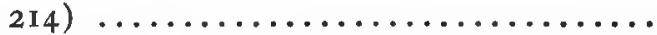

Oidemia fusca (Velvet Scoter)...... (Plate 36, Fig. 212)

Old Squaw (Harelda hyemalis)....... (Plate 36, Fig. 208

Olor atratus (Australian Black Swan) .............. 54

“ buccinator (Trumpeter Swan) $\ldots \ldots \ldots \ldots \ldots \ldots . .65$

" columbianus (Whistling Swan) $\ldots \ldots \ldots \ldots \ldots \ldots . \quad 55$

Oreortyx pictus (Mountain Partridge) .............. 92

Oriole, Baltimore (Icterus galbula) $\ldots \ldots \ldots \ldots \ldots \ldots$ I91

“ Golden (Oriolus galbula)..... (Plate II, Fig. 5I) I90

Orioles $\ldots \ldots \ldots \ldots \ldots \ldots \ldots \ldots \ldots \ldots \ldots \ldots \ldots$ I90

Ortalis vetula maccali (Chacalacca) .............. 79

Ortolan (Emberiza hortulana)......(Plate 16, Fig. 87) 223

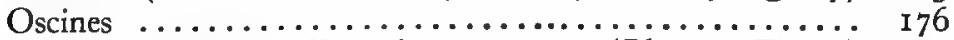

Osprey (Pandion haliaëtus) ............ (Plate 2, Fig. 6) 69

Otis tarda (Great Bustard) ......... (Plate 30, Fig. 169) 98

Ostrich (Struthio camelus)........ (Plate 28, Fig. I57) 5

Otocoris alpestris (Horned Lark) ............... 2II

Ouzel, Ring (Merula torquatus)..... (Plate II, Fig. 56) 196 "European Water (Cinclus cinclus)...... (Plate Io, Fig. 50) $\ldots \ldots \ldots \ldots \ldots \ldots \ldots \ldots \ldots \ldots \ldots \ldots \ldots$

Oven-bird (Seiurus aurocapillus) $\ldots \ldots \ldots \ldots \ldots \ldots .205$ 
European Barn (Strix flammea).. (Plate 5, Fig. 21) 162

Barred (Syrnium varium) ............... 162

Great Eagle (Bubo bubo).......(Plate 5, Fig. 18) 159

Great Grey (Scotiaptix nubulosa) .......... 162

Great Horned (Bubo virginianus) $\ldots \ldots \ldots \ldots \ldots$ I 58

American Hawk (Surnia ulula caparoch)....... 163

Little (Athene noctua) ......... (Plate 5, Fig. 22) 160

European Long-eared (Asio otus) .. (Plate 5, Fig. 20) I6I

Little Screech (Megascops asio) ............. 162

Snowy (Nyctea nyctea)........(Plate 5, Fig. 23) 160

Tawny (Syrnium aluco) ........ (Plate 5, Fig. I9) I6i

Oxyechus vociferus (Killdeer)............... I03

Oyster-catcher, Black (Hæmatopus bachmani)........ I I 2

" American (Hæmatopus palliatus) ...... I I 2

$\mathbf{P}$

Pandion haliaëtus (Osprey)........... (Plate 2, Fig. 6)

Padda orizyvora (Java Sparrow) ..... (Plate I7, Fig. 99)

Paroquet, Carolina (Conurus carolinensis)..... (Plate 7 , Fig. 32$) \quad \ldots \ldots \ldots \ldots \ldots \ldots \ldots \ldots \ldots$

“ Zebra grass (Melopsittacus undulatus)... (Plate

8, Fig. 38) $\ldots \ldots \ldots \ldots \ldots \ldots \ldots \ldots \ldots$

Parrot, Blue-fronted Amazon (Amazona æestiva)... (Plate

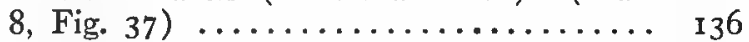

" Grey. (Psittacus erythacus).... (Plate 7, Fig. 33) I34

" Kea (Nestor notabilus) ............... I34

"Owl (Stringops habroptilus) ............ I38

Partridge, California (Lophortyx californicus)........ 92

"Common European (Perdix perdix).. (Plate 24, Fig. 144)

“ Gambel (Lophortyx gambelii)...(Plate 4I, Fig.

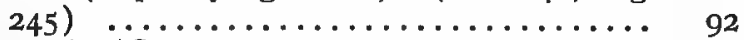

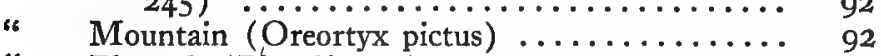

“ Plumed (Plumiferous) .............. 92

“ Red-legged Rock (Cacabis saxatilis).... (Plate 25, Fig. 145) ................ 87

“ Scaled (Callipepla squamata) ........... 92

Parus ater (Coal Tit)............ (Plate I5, Fig. 80) 183 atricapillus (Chickadee) $\ldots \ldots \ldots \ldots \ldots \ldots \ldots \ldots$ I 84 coerulus (Blue Tit).......... (Plate 15, Fig. 83. 182 major (Great Tit).......... (Plate 15, Fig. 84) 183 
Passer domesticus (European House Sparrow).. (Plate I6, Fig. 93) $\ldots \ldots \ldots \ldots \ldots \ldots \ldots \ldots, 215$ " montanus (European Tree Sparrow).... (Plate 16, Fig. 94) $\ldots \ldots \ldots \ldots \ldots \ldots \ldots \ldots \ldots \ldots \ldots \ldots \ldots \ldots, 216$ PASSERIFORMES ..................... 172

Passerina nivalis (Snow Bunting).... (Plate 16, Fig. 89) 221 Pavo cristatus (Peacock).......... (Plate 25, Fig. 148) 84 " muticus (Javan Peacock) .................. 85

Pavoncella pugnax (Ruff)......... (Plate 3I, Fig. I8I) III Peacock (Pavo cristatus).......... (Plate 25, Fig. I48) 84 Javan (Pavo muticus) .................. 85

Pedircestes phasianellus (Sharp-tailed Grouse)........ 89

Pelican; American White (Pelecanus erythrorhynchus).... 28

" Brown (Pelecanus occidentalis) ............ 29

“ European (Pelecanus onocrotalus)... (Plate 37, Fig. 220)

Pelicans 28

Pelicanus erythrorhynchus (American White Pelican).... ${ }_{28} 8$

" occidentalis (Brown Pelican) ............ 29

“ onocrotalis (European Pelican).. (Plate 37, Fig. 220)

Pelidna alpina (Dunlin) .......... (Plate 32, Fig. I85) 108

Penguin, Emperor (Aptenodytes longirostris) ........ 2I

King (Aptenodytes patagonica)... (Plate 40, Fig.

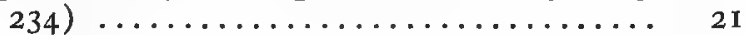

“ Little (Aptenodytes parvus).(Plate 40, Fig. 235) 2I Perisoreus canadensis (Canada Jay) .............. 23I Perdix perdix (European Partridge)..(Plate 24, Fig. I44) 87 Petrel, Giant .......................... 2 I

Leach's (Oceanodroma leucorhoa)... (Plate 37, Fig.

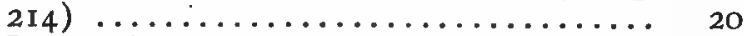

“ Little Stormy (Procellaria pelagica) .......... 20

" Snow ............................. 20

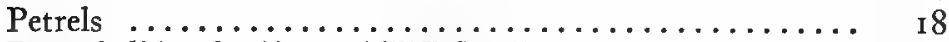
I8

Petrochelidon lunifrous (Cliff Swallow) $\ldots \ldots \ldots \ldots \ldots \ldots \ldots \ldots$
Pewee, Wood (Contopus virens) $\ldots \ldots \ldots \ldots \ldots \ldots \ldots$

Phænicopterus roseus (European Flamingo).... (Plate 33, Fig. I89)

ruber (American Flamingo) 42 42

Phaëthon æthereus (Tropic Bird).... (Plate 37, Fig. 216) 32

Phalarope, Wilson's (Crymophilus fulicarius) ......... II 3

Phalocorax carbo (Common Cormorant).. (Plate 37, Fig. 218) 
Phalocorax harrisi (Harris's Cormorant) ......... 25

Pharomacrus mocinno (Resplendent Trogon) ........ I65

Phasianus colchicus (Common European Pheasant).....

(Plate 26, Fig. I50) ............. 82

“ reevesi (Reeves Pheasant) ............ 84

“ torquatus (Ring-necked Pheasant) ........ 82

Pheasant, Common European (Phasianus colchicus)....

(Plate 26, Fig. I50) $\ldots \ldots \ldots \ldots \ldots \ldots \ldots \quad 82$

“ Argus (Argusianus argus).... (Plate 26, Figs.

$152,153) \ldots \ldots \ldots \ldots \ldots \ldots \ldots \ldots \ldots \ldots \ldots \ldots$

“ Golden (Chrysolophus pictus)... (Plate 25, Figs.

146, 147) .................... 83

" Impeyan (Lophophorus impeyanus) ....... 83

" Lady Amherst (Chrysolophus amherstiæ)..... 84

" Reeves (Phasianus reevesi) ............. 84

" Ring-necked (Phasianus torquatus) ....... 82

“ Silver (Gennæus nycthemerus).... (Plate 26,

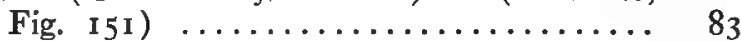

Philohela minor (American Woodcock) .......... 106

Phœbe (Sayornis phœbe) $\ldots \ldots \ldots \ldots \ldots \ldots \ldots \ldots \ldots \ldots$ I 75

Phoebetria fuliginosa (Sooty Albatross) $\ldots \ldots \ldots \ldots \ldots \ldots$ I9

PHCENICOPTERI .................... 23

Phylloscopus sibilatrix (Wood Wren)..(Plate 13, Fig. 67) 202

Pica pica (European Magpie)...... (Plate 20, Fig. I 15) 23 I

" " hudsonia (American Magpie) ........... 231

PICI vanicus)

209

Picus martius (Great Black Woodpecker).. (Plate 6, Fig. 28)

Pigeon, Band-tailed (Columba fasciata)

Blood-breasted (Columba livia var.)

Carrier (Columba livia var.) .............. I3 I

Crowned (Goura coronata).. (Plate 23, Fig. 136) I28

Fantail (Columba livia var.) ........... I32

Nicobar (Calonas nicobarica) $\ldots \ldots \ldots \ldots \ldots \ldots . . .128$

Passenger (Ectopistes migratorius).... (Plate 22,

Fig. 133) ................. 126

“ Pouter (Columba livia, var.)..(Plate 23, Fig. I34) I30

"Wood (Columba palumbus) . (Plate 22, Fig. 132) I29

Pinicola enucleator (Pine Grosbeak)..(Plate 16, Fig. 92) 218

Pintail (Dafila acuta) ........... (Plate 35, Fig. 205) 47

Pipit, American (Anthus pensilvanicus) ........... 209

" Meadow (Anthus pratensis) .............. 209

“ Tree (Anthus trivialis)........ (Plate Io, Fig. 49) 209 
Pipits ................................ 207

Piranga erythromelas (Scarlet Tanager) ............ 225

rubra (Summer Tanager) ............... 226

Platalea leucorodia (European Spoonbill).. (Plate 33, Fig.

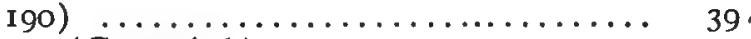

Plautus impennes (Great Auk) ............... I23

Plegadis autumnalis (Glossy Ibis) ............... 4I

Plover, Golden (Charadrius dominicus).. (Plate 30, Fig.

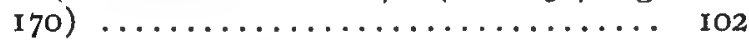

“ Kentish (Ægialitis alexandrina)... (Plate 30, Fig.

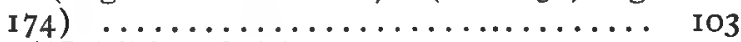

" Piping (Ægialitis meloda) ............... 103

" Ringed (Ægialitis hiaticula).(Plate 30, Fig. I73) I02

Podilymbus podiceps (Pied-billed Grebe) ............ I7

Polyborus cherivay (Caracara)................ (Plate) 68

Porzana jamaicensis (Little Black Rail) ........... 98

" porzana (Spotted Crake).... (Plate 29, Fig. I66) 96

“ carolina (Carolina Rail) ................ 97

Pratincola rubicola (Stonechat).......(Plate 12, Fig. 62) 197

Pratincole (Glareola pratincola)..... (Plate 31, Fig. I75) Ior

Progne subis (Purple martin) ................. 180

Psittacus erythacus (Grey Parrot).. (Plate 7, Fig. 33).... I I34

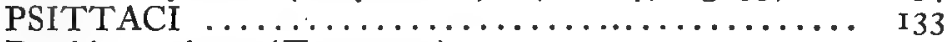

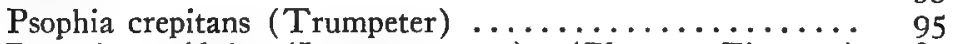

Ptarmigan, Alpine (Lagopus mutus)...(Plate 24, Fig. I43) 89

"Willow (Lagopus lagopus) $\ldots \ldots \ldots \ldots \ldots$...... 90

Puffin (Fratercula arctica).......... (Plate 39, Fig. 233) 122

"Horned (Fratercula corniculata) ............. 123

"Tufted (Lunda cirrhata) .................. 123

Puffinus puffinus (Manx Shearwater)..(Plate 37, Fig. 215) 20

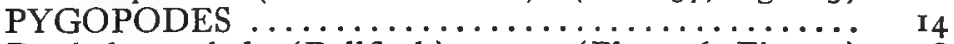

Pyrrhula pyrrhula (Bullfinch)........ (Plate I6, Fig. 91) 218

Quail, Common European (Coturnix coturnix).. (Plate 24,

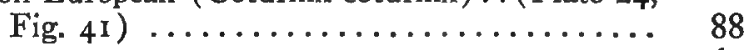

Quetzel ............................. ${ }_{165}$

Querquedula discors (Blue-winged Teal) $\ldots \ldots \ldots \ldots \ldots .4{ }_{48}$

Quiscalus quiscula (Purple Grackle) ............ 193

$\mathrm{R}$

Rail, Clapper (Rallus crepitans) $\ldots \ldots \ldots \ldots \ldots \ldots \ldots .97$

" King (Rallus elegans) ................... 97

“ Little Black (Porzana jamaicensis) ............. 98 
Rail, Virginia (Rallus virginianus) ............ 97

"Water (Rallus aquaticus)..... (Plate 29, Fig. 163) 98

Rallus crepitans (Clapper Rail) . ............ 97

" elegans (King Rail) ................ 97

Raven, American (Corvus corax sinuatus) .......... 229

" European (Corvus corax).... (Plate 20, Fig. II6) 229

Recurvirostra avocetta (European Avocet). (Plate 32, Fig.

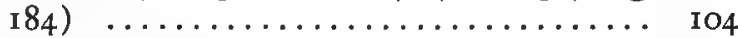

Redpoll (Acanthis linaria) ................... 220

Redshank (Totanus totanus) ........ (Plate 32, Fig. 182) I I

Redstart, American (Setophaga ruticilla)........... 203

Black (Ruticilla titys) ..... (Plate 13, Fig. 66) 197

a European (Ruticilla phonicurus). (Plate 13, Fig.

65) ........................ 197

Reedbird (Dolichonyx orizyvorus) ............ I92

Regulus calendula (Ruby-crowned Kinglet) .......... 202 regulus (Golden-crested Wren). (Plate 13, Fig.

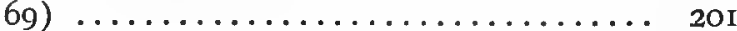

"satrapa (Golden-crowned Kinglet)........... 202

Rhampastos toco (Giant Toucan) ...... (Plate 9, Fig. 4I) I66

Rhea, Common (Rhea americana)....(Plate 28, Fig. I58) 4, 5

Rhynchotus rufescens (Rufus Tinamou).(Plate 4I, Fig. 240).

Rhynchops nigra (Black Skimmer).

Riparia riparia (Bank Swallow)..... (Plate I9, Fig. I Io)

Rissa tridactyla (Kittiwake)........ (Plate 38, Fig. 225)

Road-runner (Geococcyx californiaus). (Plate 4I, Fig. 246) Robin, American (Merula migratoria) ..............

" European (Erythacus rubecula). (Plate I2, Fig. 6I)

Roller, European (Coracias garrulus)... (Plate 9, Fig. 43) Rook (Corvus frugilegus)......... (Plate 20, Fig. I I 7 ) Ruff (Pavoncella pugnax).......... (Plate 3I, Fig. I8I) Rupicola rupicola (Cock-of-the-rock). (Plate I9, Fig. I I2) Ruticilla phœnicurus (European Redstart). (Plate I3, Fig. 65)

179

117

I4I

199

198

142

229

II I

173

197

S

Sanderling (Calidris arenaria)......(Plate 32, Fig. 188) Sandpiper, Curlew (Erolia ferruginea). (Plate 32, Fig. I86) Least (Actodromas minutilla)

IIO 109 109

Sandpiper, Semipalmated (Ereunetes pusillus) 109 Sapsucker, Yellow-bellied (Sphyrapicus varius) .......... Sarcoramphus gryphus (South American Condor). (Plate I, Fig. 1 ) $\ldots \ldots \ldots \ldots \ldots \ldots \ldots \ldots \ldots$ 
Saxicola ænanthe (Wheatear)........ (Plate 12, Fig. 60)

PAGE

Scolopax rusticola (European Woodcock). (Plate 3I, Fig.

196

Scoter, Velvet (Oidemia fusca) ........ (Plate $36, \mathrm{Tig}, 212)$

Scter, Velvet (Oidemia fusca) ....... (Plate 36, Fig. 212) 46

Scotiaptix nebulosa (Great Grey Owl) ............. I62

Secretary Bird (Serpentarius secretarius). (Plate 3, Fig. 13) 59

Seiurus aurocapillus (Oven-bird) $\ldots \ldots \ldots \ldots \ldots \ldots \ldots .205$

Seriema (Cariama cristata)..........(Plate 42, Fig. 245) 94

Serin (Serinus hortulanus) .......... (Plate 18, Fig. I02) 214

Serinus canarius (Canary)......... (Plate 18, Fig. 105) 215

Serpentarius secretarius (Secretary Bird). (Plate 3, Fig. I3) 59

Shearwater, Manx (Puffinus puffinus). (Plate 37, Fig. 215) 20

Sheldrake (Tadorna tadorna)....... (Plate 36, Fig. 209) 50

Shrike, Great Grey (Lanius excubitor).(Plate Io, Fig. 46) 18 I

" Loggerhead (Lanius ludovicianus)............. I82

“ Northern (Lanius borealis)............... I8I

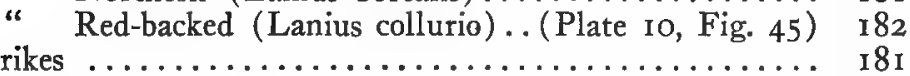

Shrikes

Sialis sialis (Bluebird) $\ldots \ldots \ldots \ldots \ldots \ldots \ldots \ldots \ldots \ldots \ldots \ldots \ldots \ldots$

Siskin (Spinus spinus)........... (Plate 18, Fig. I03) 214

" Pine (Spinus pinus).................... 214

Sitta canadensis (Red-breasted Nuthatch)........... 186

" carolinensis (White-breasted Nuthatch) .......... I85

" cæsia (European Nuthatch).... (Plate 21, Fig. 127) I85

Skimmer, Black (Rhynchops nigra)................ I 8

Skua, Parasitic (Stercorarius parasiticus). (Plate 38, Fig. 226) ........................ I I I

Skylark (Alauda arvensis)...........(Plate I4, Fig. 74) 210

Smew (Mergus albellus).......... (Plate 36, Fig. 210) 46

Snake-bird (Anhinga anhinga).......(Plate 38, Fig. 222) 25

Snipe, Common European (Gallinago gallinago). (Plate 31, Fig. 178) .................... 105

"Great (Gallinago média).... (Plate 31, Fig. 179) 105

“ Jack (Gallinago gallinula)................. I05

Snowbird (Junco hyemalis)................. 22r

Snowflake (Passerina nivalis) ................ 22.

Somateria mollissima (Eider Duck)...(Plate 35, Fig. 206) 46

Sparrow, Chipping (Spizella socialis) ............ 216

Field (Spizella pusilla)............... 216

“ House (Passer domesticus)..(Plate 16, Fig. 93) 215

" Hedge (Accentor modularis).(Plate I2, Fig. 58) 203

“ Java (Padda oryziva)...... (Plate I7, Fig. 99) 222

“ Song (Melospiza cinerea melodia)............. 216

“ American Tree (Spizella monticola)........ 216 
Sparrow, European Tree (Passer montanus)..(Plate 16, Fig. 94) ...................... 216

Spathura underwoodi (Racquet-tailed Humming-bird) (Plate 2I, Fig I25).............. 153

Speotyto cunicularia hypogæa (Burrowing Owl)....... I6o

Sphyrapicus varius (Yellow-bellied Sapsucker)......... I69

Spinus pinus (Pine Siskin) $\ldots \ldots \ldots \ldots \ldots \ldots \ldots \ldots$ 214 " spinus (Siskin).......... (Plate I8, Fig. IO3) 214

Spizella montanus (European Tree Sparrow). (Plate I6,

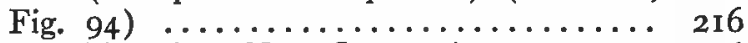

“ monticola (American Tree Sparrow) ......... 216

Spoonbill, European (Platalea leucorodia). (Plate 33, Fig.

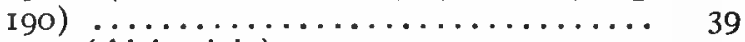

“ Roseate (Ajaia ajaja) ................ 39

Sporæginthus amandava (Amaduvade). (Plate 7, Fig. 96) 221

Starling, Common (Sturnus vulgaris). (Plate 20, Fig. 120) 194

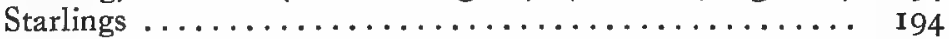

STEGANOPODES $\ldots \ldots \ldots \ldots \ldots \ldots \ldots \ldots \ldots .23$

Stercorarius parasitacus (Parasitic Skua).(Plate 38, Fig.

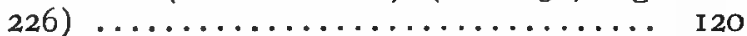

Sterna antillarum (Little Tern)............... I I9

120

120

119

120

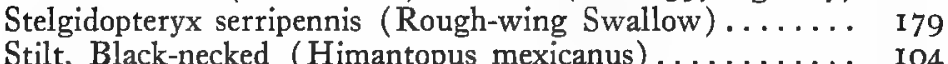

Stilt, Black-necked (Himantopus mexicanus).......... I04

“European (Himantopus himantopus). (Plate 30, Fig. I 72) $\ldots \ldots \ldots \ldots \ldots \ldots \ldots \ldots \ldots \ldots \ldots \ldots \ldots \ldots \ldots$ I0 4

Stint, Little (Actodromas minuta)... (Plate 32, Fig. I83) 109 Stonechat (Pratincola rubicola).......(Plate 12, Fig. 62) 197

Stork, African Adjutant (Leptoptilus crumenifer). (Plate

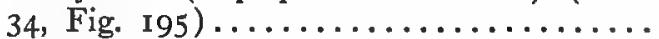

“ European White (Ciconia ciconia). (Plate 33, Fig. 19r $\quad \ldots \ldots \ldots \ldots \ldots \ldots \ldots \ldots \ldots \ldots \ldots \ldots \ldots \ldots \ldots, 38$

“ Indian Adjutant (Leptoptilus argala) ........... 38

"Whale-headed ......................... 39

Streptopelia risoria (Ring Dove) ................ I I28

STRIGES ........................... ${ }_{156}$

Stringops habroptilus (Owl Parrot) ............. I 138

Strix flammea (European Barn Owl) ... (Plate 5, Fig. 2I) I62

" pratincola (American Barn Owl) ............. I6I

Struthio camelus (African Ostrich)...(Plate 28, Fig. 157) 5

Sturnella magna (Meadowlark) ................. I93 
Sturnus vulgaris (Starling)........ (Plate 20, Fig. 120)

Sula bassana (Common Gannet)..... (Plate 37, Fig. 217)

Surnia ulula caparoch (American Hawk Owl) .........

Swallow, American Bank (riparia riparia). (Plate I9, Fig.

" American Barn (Hirundo erythrogastra)......

" European Barn (Hirundo rustica). (Plate I8,

Fig. 108$) \ldots \ldots \ldots \ldots \ldots \ldots \ldots \ldots$

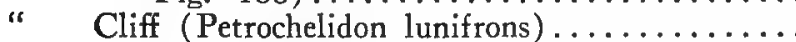

" Rough-wing (Stergidopteryx serripennis)......

Swallows

Tree (Iridoprocne bicolor) . ...............

I79

I79

I 79

180

179

I 80

178

Swan, Australian Black (Olor atratus)

European Mute (Cygnus olor). (Plate 35, Fig. 20I)

54

55

Black-necked (Olor nigricollis) ............

Trumpeter (Olor buccinator)

55

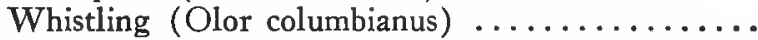

Swift, Common European (Cypselus apus) . (Plate I 8, Fig.

Chimney (Chæi $10 . \ldots \ldots$ pelagica.

“ Chimney (Chætura peläica.

Sylvia atricapilla (Blackcap).

150

Symphemia semipalmata (Willet)

(Plate 13, Fig. 72)

Syrnium aluco (Tawny Owl).

" varium (Barred Owl).

(Plate 5, Fig. I9)

$\mathrm{T}$

Tadorna tadorna (Sheldrake)........ (Plate 36, Fig. 209

Tanager, Paradise (Calospiza tatao)... (Plate 19, Fig. II3

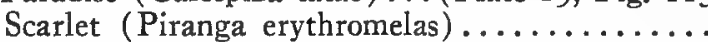

50

226

225

Summer (Piranga rubra)

226

Tanagers

225

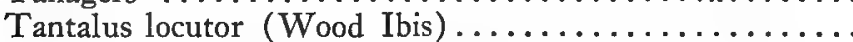

Tern, Bridled (Sterna anæthetus)

I 20

" Common (Sterna hirundo).... (Plate 39, Fig. 230)

"Least, European (Sterna minuta). (Plate 39, Fig.

I 19 227)

I 20

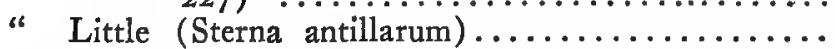

I 20

Noddy (Anous stolidus) ................. I 19

" Royal (Sterna maxima)..................... I 19

"Sooty (Sterna fuliginosa) ............... 120

Tetrao urogallus (Capercailzie) ......(Plate 24, Fig. I38) 90

Tetrastes bonasia (Hazel Grouse).... (Plate 24, Fig. I40) 91 
Tetrax tetrax (Little Bustard) .....(Plate 29, Fig. I62) PAGR

Tetrax tetrax (Little Bustard) ......(Plate 29, Fig. I62) 99

Thrasaëtus harpyia (Harpy Eagle).. (Plate 42, Fig. 24I) 66

Thrasher, Brown (Toxostoma rufum)............ 189

Thrush, Hermit (Hylocichla guttata pallasii)........ 200

"Missel (Turdus viscivorus)..(Plate I I, Fig. 55) 195

“ Rock (Monticola saxatalis)...(Plate I2, Fig. 57) I96

"Wilson's (Hylocichla fuscescens)........... 200

"Wood (Hylocichla mustelina)............ 199

Tichodroma muraria (Wall-creeper). (Plate 21, Fig. 126) 187

Tinamou, Rufus (Rhynchotus rufescens)...(Plate 4I, Fig. 240)

Tit, Blue (Parus coruleus)........... (Plate 15, Fig. 83)

"Coal (Parus ater) ............. (Plate 15, Fig. 8o)

"Crested (Lophophanes cristatus). (Plate 15, Fig. 82)

"Great (Parus major).......... (Plate I5, Fig. 84)

“ Long-tailed (Acredula caudata)...(Plate I4, Fig. 78)

Titmouse, Tufted (Bæolophus bicolor) ..............

Titmice

Topaza pella (Topaz Humming-bird) . (Plate 21, Fig. 124)

Totanus melanoleucus (Greater Yellowlegs)...........

" nebularius (Greenshank).... (Plate 3I, Fig. I80).

" totanus (Redshank)....... (Plate 32, Fig. I82)

Toucan, Giant (Rhampastos toco).... (Plate 9, Fig. 4I) Short-billed

Towhee (Pipilo erythrophthalmus).

182

183

183

183

183

184

182

153

106

107

I 12

166

I 66

220

Toxostoma rufum (Brown Thrasher)............ I89

Tringa canutus (Knot) ..........(Plate 32, Fig. I 87 ) I I0

Trochilus colubris (Ruby-throated Humming-bird) ...... I 54

Trogon, Resplendent (Pharomacrus mocinno) ......... I65

TROGONES African (Hapaloderma narina). (Plate 9, Fig. 44) I65

Tropic-bird (Phaëton athereus) ..... (Plate 37 Fig 216)

Tropic-bird (Phačton athereus) ......(Plate 37, Fig. 216) 32

Trumpeter (Psophia crepitans) ................ 95

TUBINARES ......................... I4

Turdus viscivorus (Missel Thrush)... (Plate I I, Fig. 55) I95

Turkey, Eastern Wild (Meleagris sylvestris)........ 8I

"Honduras (Meleagris ocellata).......... 8I

“ Mexican Wild (Meleagris gallopavo). (Plate 27,

Fig. 155$) \ldots \ldots \ldots \ldots \ldots \ldots \ldots \ldots \ldots$. 80

“ turtur (Turtle Dove)...... (Plate 23, Fig. I37) 127

Tympanuchus americanus (Prairie Hen).......... 89

Tyrannus tyrannus (Kingbird) ............. I75 
$\mathrm{U}$

PAGE

Upupa epops (Hoopoe)........... (Plate 22, Fig. 129)

I 45

Uria lomvia (Murre)............. (Plate 40, Fig. 238)

I 22

V

Vidua paradisea (Paradise Whydah-bird).(Plate I7, Fig.

Vanellus vanellus (Lapwing)........ (Plate 30, Fig. I7I)

22 I

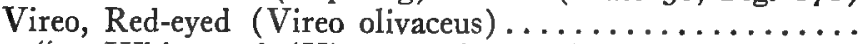

IO3

206

Vireos

White-eyed (Vireo noveborensis)

206

Vulture, Black (Catharista urubu)

206

Egyptian (Neophron percnopterus).(Plate I, Fig. 2)...

“ Griffon (Gyps fulvus)..........(Plate 2, Fig. 5)

73

73

Turkey (Cathartes aura).... (Plate 4I, Fig. 243) 76 King (Gypagus papa).......... (Plate 2, Fig. 5) 74

\section{W}

Wagtail, Grey (Motacilla melanope). (Plate I I, Fig. 52) 208 Pied (Motacilla lugubris)...(Plate I I, Fig. 53) 208 White (Motacilla alba) ................ 208

Yellow (Budytes rayi) ................ 208

Wagtails 207

Warbler, Blue-winged (Helminthophila pinus)........ 204

" Chestnut-sided (Dendroica pensylvanica) ..... 205

" Hooded (Wilsonia mitrata) ............. 204

“ Icterine (Hypolais hypolais). (Plate I3, Fig. 70) 202

“ Marsh (Acrocephalus palustris). (Plate I3, Fig. 64) ......................... 202

“ Myrtle (Dendroica coronata) ............ 204

“ Parula (Compsothlypis americana) .......... 205

Warblers

Waxwing, Bohemian (Ampelis garrulus).(Plate 18, Fig. 200 106) $\ldots \ldots \ldots \ldots \ldots \ldots \ldots \ldots \ldots \ldots \ldots \ldots \ldots \ldots$ 190

" Cedar (Ampelis cedrorum) ............. I90

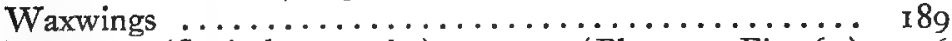

Wheatear (Saxicola ænanthe)........(Plate 12, Fig. 60) 196

Whippoorwill (Antrostomus vociferus) ............. I 49

White-throat (Sylvia cinerea)........ (Plate I3, Fig. 7I) 201

Whydah-bird, Paradise (Viddua paradisea). (Plate 17, Fig. 
Widgeon (Marecca penelope)........ (Plate 35, Fig. 204)

Willet (Symphemia semipalmata) ................ I06

Wilson, Alexander ....................... 126

Woodcock, American (Philohela minor)............ 106

European (Scolopax rusticola). (Plate 31, Fig.

177) $\ldots \ldots \ldots \ldots \ldots \ldots \ldots \ldots \ldots \ldots \ldots \ldots \ldots \ldots \ldots$

Woodpecker, Ivory-billed (Campephilus principalis). (Plate 6 , Fig. 25) ................. 168

" Downy (Dryobates pubescens) ........... 169

“ Great Black (Picus martius). (Plate 6, Fig. 28) $\ldots \ldots \ldots \ldots \ldots \ldots \ldots \ldots \ldots \ldots \ldots \ldots \ldots$

“ Great Spotted (Picus major)............... 169

“ Green (Gecinus viridis).. (Plate 6, Fig. 26) 169

“ Grey-headed Green (Gecinus canus). (Plate 6, Fig. 24) .................... I69

" Hairy (Dryobates villosus) ............ 169

" Lesser Spotted (Dryobates minor). (Plate 6, Fig. 27$) \ldots \ldots \ldots \ldots \ldots \ldots \ldots \ldots \ldots$. 169

" Red-headed (Melanerpes erythrocephalus)

(Plate 7, Fig. 29)................ 169

Wren, Carolina (Thyothorus ludovicianus) ......... 88

" Golden-crested (Regulus regulus).(Plate I3, Fig.

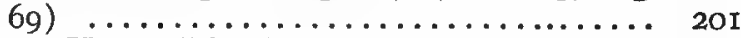

" European House (Troglodytes troglodytes).(Plate

13, Fig. 68) .................... . 88

"Common American House (Troglodytes aëdon)...

“ Marsh (Telmatodytes palustris) .............. I 188

“ Winter (Olbiorchilus hiemalis)............. I 88

“Wood (Phylloscopus sibilatrix). (Plate 13, Fig. 67)

202

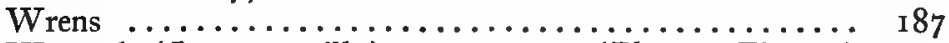

Wryneck (Jynx torquilla)........... (Plate 7, Fig. 3I) I70

\section{Y}

Yellowhammer (Emberiza citrinella)..(Plate I5, Fig. 85) 223

Yellowlegs (Totanus flavipes) $\ldots \ldots \ldots \ldots \ldots \ldots \ldots \ldots$. 106

Greater (Totanus melanoleucus) .......... I06

Yellowthroat, Maryland (Geothlypis trichas).......... 204

Zapornia parva (Little Crake)...... (Plate 29, Fig. I64) 97 Zenaidura macroura (Mourning Dove)............ I 97 





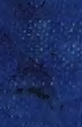

